UNIVERSIDADE DE SÃO PAULO

FACULDADE DE ECONOMIA, ADMINISTRAÇÃO E CONTABILIDADE DEPARTAMENTO DE CONTABILIDADE E ATUÁRIA

PROGRAMA DE PÓS-GRADUAÇÃO EM CONTROLADORIA E CONTABILIDADE

INVESTIMENTOS SOCIOAMBIENTAIS NA DEMONSTRAÇÃO DO VALOR ADICIONADO: FORMAÇÃO OU DISTRIBUIÇÃO DO VALOR ADICIONADO?

Mariana Simões Ferraz do Amaral Fregonesi

Orientador: Prof. Dr. Ariovaldo dos Santos 
Profa. Dra. Suely Vilela

Reitora da Universidade de São Paulo

Prof. Dr. Carlos Roberto Azzoni

Diretor da Faculdade de Economia, Administração e Contabilidade

Prof. Dr. Fábio Frezatti

Chefe do Departamento de Contabilidade e Atuária

Prof. Dr. Edgard Bruno Cornachione Júnior

Coordenador do Programa de Pós-Graduação em Controladoria e Contabilidade 


\section{INVESTIMENTOS SOCIOAMBIENTAIS NA DEMONSTRAÇÃO DO VALOR ADICIONADO: FORMAÇÃO OU DISTRIBUIÇÃO DO VALOR ADICIONADO?}

Tese apresentada ao Departamento de Contabilidade e Atuária da Faculdade de Economia, Administração e Contabilidade da Universidade de São Paulo, como requisito para a obtenção do título de Doutor em Controladoria e Contabilidade.

Orientador: Prof. Dr. Ariovaldo dos Santos 
Tese defendida e aprovada no Departamento de Contabilidade e Atuária da Faculdade de Economia, Administração e Contabilidade da Universidade de São Paulo - Programa de Pós-Graduação em Controladoria e Contabilidade, pela seguinte banca examinadora:

Fregonesi, Mariana Simões Ferraz do Amaral Investimentos socioambientais na demonstração do valor adicionado: formação ou distribuição do valor adicionado? / Mariana Simões Ferraz do Amaral Fregonesi. -- São Paulo, 2009.

$222 \mathrm{p}$.

Tese (Doutorado) - Universidade de São Paulo, 2009.

Bibliografia.

1. Balanço social 2. Valor adicionado 3. Responsabilidade social I. Universidade de São Paulo. Faculdade de Economia, Administração e Contabilidade II. Título.

CDD - 657 
Dedico este trabalho ao meu marido, Luiz Gustavo. 

Agradeço a Deus por cada vez que Ele me levantou neste difícil processo de doutoramento. Ele esteve comigo em todos os momentos, mostrando que era possível e me mostrando o melhor caminho. Sem Sua força eu não teria conseguido.

Agradeço imensamente ao Prof. Dr. Ariovaldo dos Santos que acreditou em mim, mesmo sem me conhecer, e foi paciente em toda minha indecisão no processo de elaboração desta tese. Obrigada pelo exemplo que o senhor é para nós, acadêmicos, e por todo o conhecimento que me transmitiu durante o doutorado.

Aos professores doutores Gilberto de Andrade Martins e Adriano Henrique Rebelo Biava, obrigada pelas importantes contribuições dadas na banca de qualificação. Agradeço também às professoras doutoras Maísa de Souza Ribeiro e Roseli da Silva pelo aprendizado que me proporcionaram e pela boa vontade para resolver minhas dúvidas sobre responsabilidade social e economia, respectivamente.

Agradeço às alunas Marília e Heloísa pela contribuição na formatação e coleta de dados. Foram dois anjinhos muito competentes que me ajudaram em momentos importantes.

Agradeço ao homem maravilhoso que Deus colocou ao meu lado, meu marido, que sempre me apoiou e me deu força, mesmo nas inúmeras vezes em que coloquei minha profissão à frente da minha família. Agradeço o carinho dispensado em cada fase difícil e pelas "broncas" em cada momento de fraqueza. Agradeço pela eterna paciência e por cada palavra sempre dita no momento certo. Obrigada por estar sempre ao meu lado. Aos meus pais, Conceição e Luiz Augusto, mais uma vez agradeço por toda a minha vida, pela oportunidade de estudar, pelo apoio em todas as minhas decisões e em cada desafio assumido. À minha mãe agradeço por todas as orações. Ao meu irmão, Rodrigo, e à minha cunhada, Maggie, agradeço pelo apoio, pela hospedagem e pelo carinho que sempre mostraram.

Agradeço a todas as pessoas da minha grande família pelo apoio, pela torcida e por entender minhas tantas ausências, especialmente, tia Teca, Fernanda, Henrique, tia Anita, Regina e Vó Clery. Minha família é a coisa mais importante da minha vida.

Agradeço aos meus amigos do doutorado, pelas valiosas discussões; aos meus amigos de muitos anos, pela torcida; e aos meus amigos docentes da FEA-RP/USP, pelo apoio.

Obrigada ao pessoal da pós, Cristina, Rodolfo, Valéria e Cidinha, e da biblioteca, Dona Irene, Gisele Adornato e Ana, pela paciência e carinho na acolhida dos meus pedidos. Se eu cheguei até aqui, devo isto a muitas pessoas, porque, graças a Deus, sempre podia contar com alguém. A todos que me ajudaram, muito obrigada! 
"Depende de nós

Se esse mundo ainda tem jeito Apesar do que o homem tem feito Se a vida sobreviverá

Depende de nós." (Ivan Lins e Vitor Martins) 


\section{RESUMO}

A Demonstração do Valor Adicionado (DVA) tornou-se obrigatória para as companhias de capital aberto que atuam no mercado brasileiro, a partir de 2008. Com cunho econômicosocial e com o objetivo de mostrar a riqueza adicionada pela empresa à economia do país, a DVA mostra a estrutura de remuneração dos fatores de produção adotada pela companhia. As informações da DVA compõem um dos indicadores do modelo GRI de Balanço Social. Esse modelo tem levado algumas empresas a divulgarem suas DVAs inserindo uma linha com os investimentos sociais dentre as linhas de distribuição de valor adicionado. Nesse contexto, esta tese buscou investigar quais as condições para os investimentos socioambientais serem considerados distribuição de valor adicionado na DVA. Para responder às questões de pesquisa, foram realizadas pesquisa teórica, sobre DVA e sobre responsabilidade social corporativa, e pesquisa empírica, com análise de conteúdo dos Relatórios de Sustentabilidade de 22 companhias abertas no Brasil. Os investimentos socioambientais identificados, na pesquisa empírica, foram analisados sob a ótica dos conceitos econômicos relacionados a valor adicionado e sob a ótica do IBGE, responsável pelo cálculo do produto nacional no país. Como conclusão, propõe-se a inclusão de uma linha na DVA, na parte de distribuição do valor adicionado, para os investimentos socioambientais que atendam às seguintes condições: (i) haver dispêndio por parte da empresa investidora, além daqueles gerados pelo próprio processo produtivo; (ii) haver benefício para a comunidade, além daqueles proporcionados pela simples existência da empresa; (iii) o consumo final do bem ou serviço, objeto de investimento social, ocorrer na comunidade; (iv) o dispêndio não representar compensação de externalidades negativas geradas pelo processo produtivo; (v) o dispêndio não representar consumo de bens ou serviços usados no processo produtivo; e (vi) não haver aproveitamento de incentivo fiscal caracterizado como dedução do tributo devido. Contudo, mudar a estrutura de uma demonstração contábil envolve muita discussão e muitas simulações para análise dos impactos da mudança. Esta tese dá início à discussão. É importante que a mudança não desestimule a realização de projetos sociais bem-sucedidos, mas é necessário incentivar maior transparência na divulgação dos projetos socioambientais das empresas. Como limitações do trabalho, destacam-se, principalmente, o uso de amostra intencional não representativa da população e o uso de Relatórios de Sustentabilidade, documento não obrigatório e, em sua maioria, não auditado. Por fim, acredita-se que o trabalho tenha contribuído para aproximar a DVA dos conceitos da Contabilidade Nacional. 


\begin{abstract}
Value Added Statement (VAS) became a mandatory practice for all publicly traded companies in Brazil since 2008. Bearing a economic and social value and having the objective to show the benefits the company has added to the domestic economy, the Value Added Statement discloses the company's own structure for the remuneration of production factors. The information brought up by the VAS compose an indicator of the GRI model of Social Report. Maybe it is due to this model that some companies have released VASs including a line with social investments amongst the lines of value added distribution. In such context, this thesis investigates what are the conditions that might allow environmental and social investments to be considered added value distribution in the VAS. In order to answer the research question a theoretical research on VAS and corporate social responsibility was conducted, as well as an empirical research based on the Sustainability Reports of 22 publicly traded companies in Brazil. The environmental and social investments identified in the empirical research were analyzed through the means of economic concepts related to value added by the IBGE, which is responsible for the publishing of the country's national gross product. The conclusion of this investigation proposes the inclusion of an VAS line, at the value added distribution part, for environmental and social investments that show the following requirements: (i) there has to be an expense on the part of the investment company, besides those generated by the production process; (ii) there has to be benefits to the community, besides those brought by the mere existence of the company; (iii) the final consumption of the good or social service has to occur inside the community; (iv) the expense cannot represent the compensation of negative externalities created by the production process; (v) the expense cannot represent the consumption of goods or services used in the production process; and (vi) there cannot be any sort of tax incentive characterized as deduction of the due amount. It is worth noting that any change in an accounting statement structure demands discussion and many simulations so as to evaluate its impact. This thesis initiates the discussion. It is important to point out that the proposed changes should not prevent well succeeded social projects to happen, but rather increase their transparency. Among the limitations of this investigation are the use of samples that do not represent a population and the use of Sustainability Reports that are not audited or mandatory documents. At any rate, this work aims at bringing the concepts of VAS closer to National Accounting.
\end{abstract}




\section{SUMÁRIO}

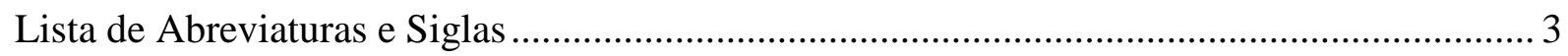

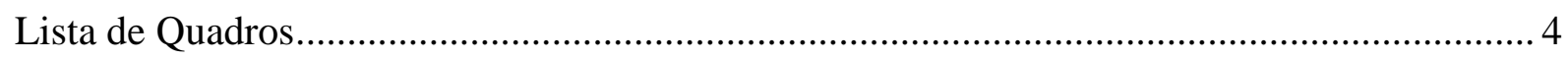

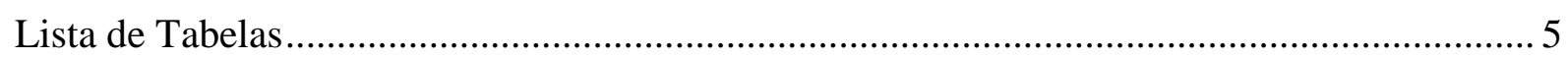

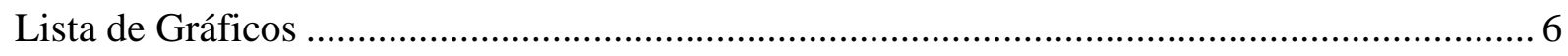

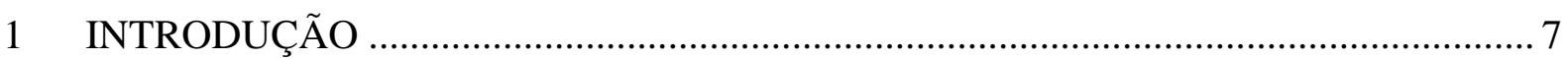

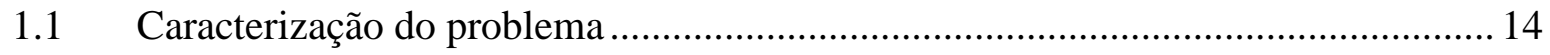

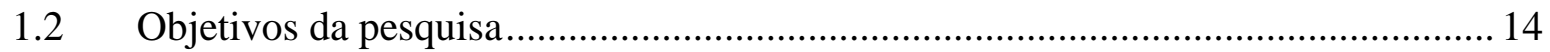

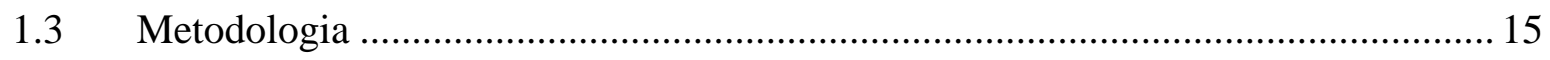

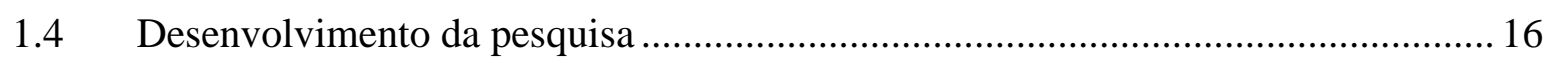

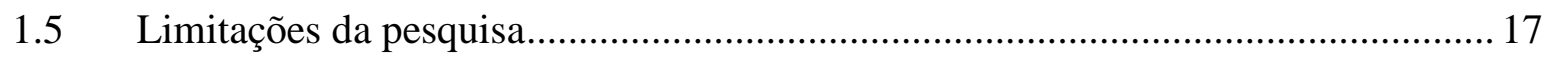

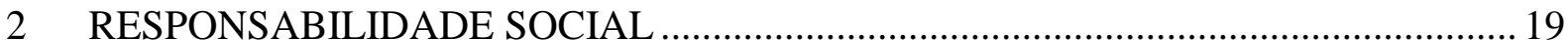

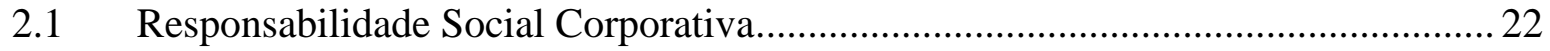

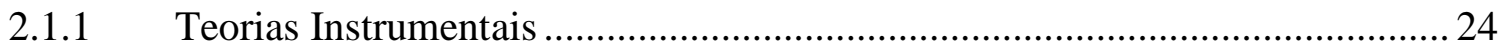

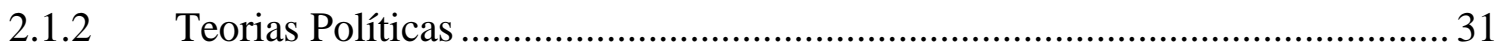

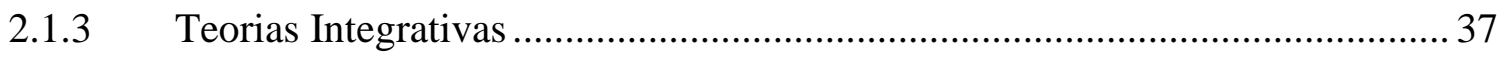

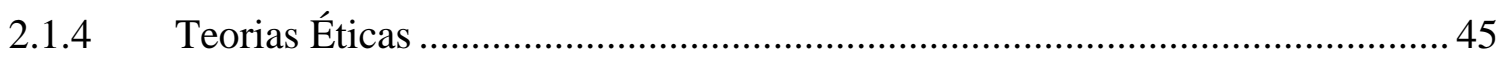

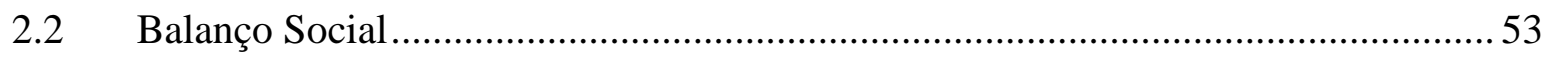

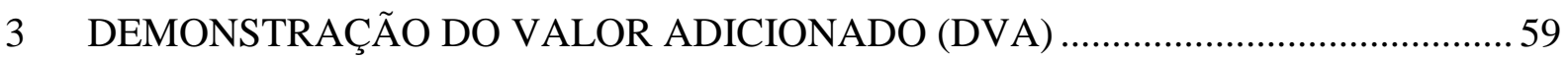

3.1 Demonstração do Valor Adicionado em outros países .............................................. 60

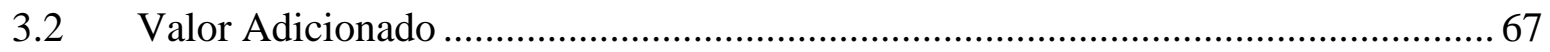

3.3 Estrutura da Demonstração do Valor Adicionado................................................. 71

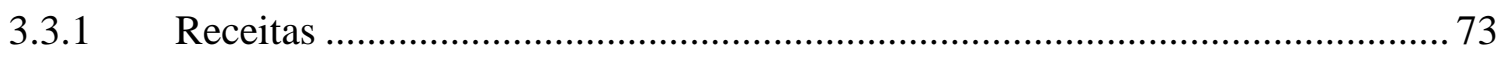

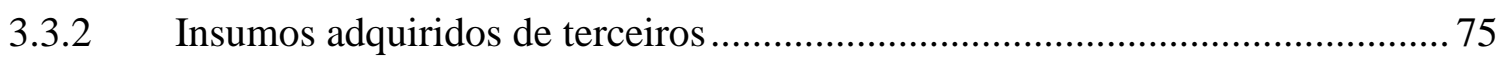

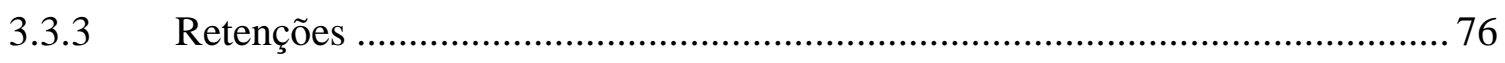

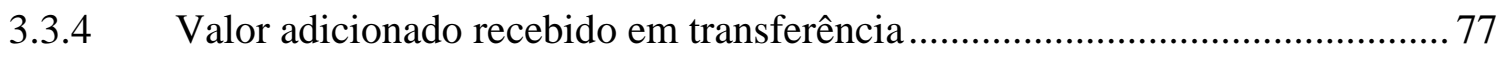

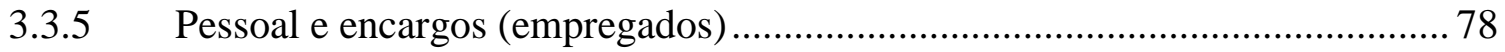

3.3.6 Impostos, taxas e contribuições (ou tributos) …….......................................... 79

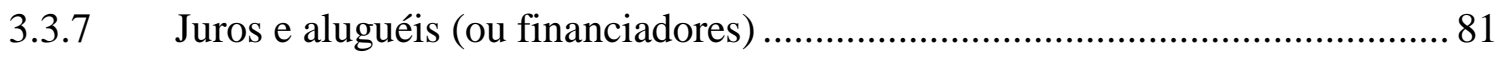

3.3.8 Juros sobre capital próprio, dividendos e lucros retidos ................................. 82

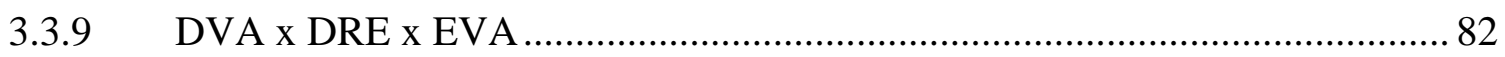

3.3.10 Evidenciação dos investimentos socioambientais na DVA ............................ 84 


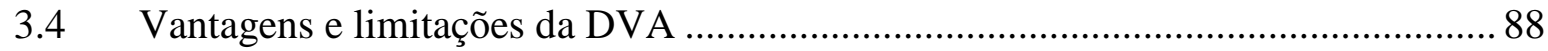

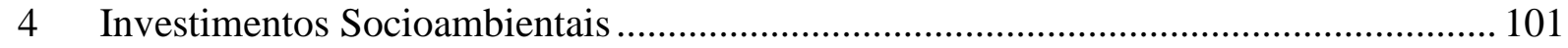

4.1 Estudo Empírico: Metodologia ….......................................................................... 104

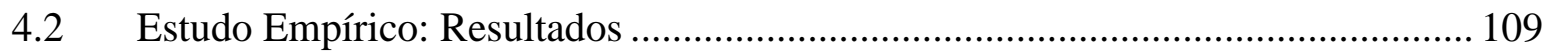

4.3 Pesquisa Empírica: Validação ........................................................................ 129

4.4 Tipologia dos Investimentos Socioambientais ................................................. 133

5 INVESTIMENTOS SOCIOAMBIENTAIS E VALOR ADICIONADO ..................... 137

5.1 Valor Adicionado X Remuneração dos Fatores de Produção .................................. 137

5.2 Análise sob a ótica do PIB brasileiro (Metodologia IBGE) .................................. 145

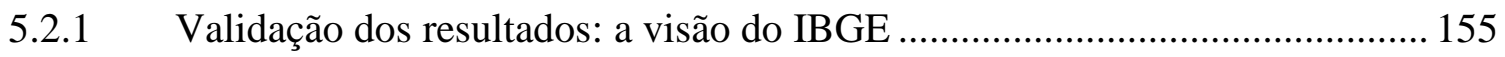

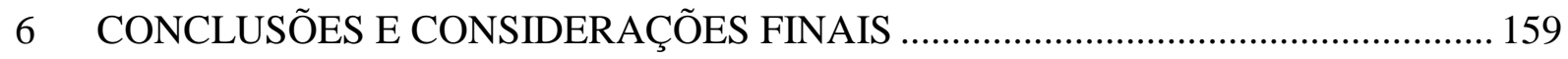

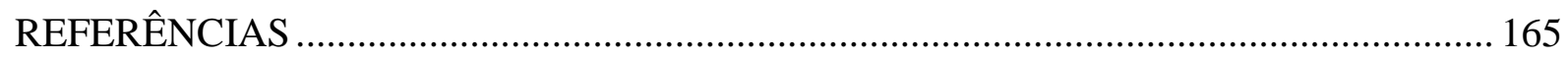

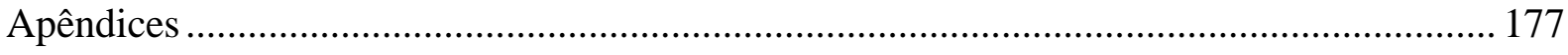

Apêndice 1 - Roteiro de análise dos Relatórios de Sustentabilidade ................................ 178

Apêndice 2 - Estrutura dos relatórios analisados no estudo empírico ............................... 185

Apêndice 3 - Gráficos da análise dos investimentos socioambientais por empresa.......... 192 Apêndice 4 - Roteiro de Entrevista para Validação da Tipologia de Investimentos

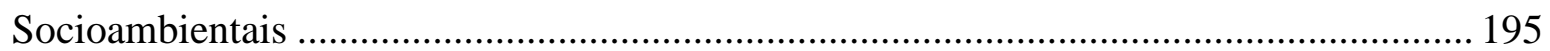

Apêndice 5 - Roteiro de Entrevista para Validação dos Resultados ................................ 197

Apêndice 6 - Tipologia usada nas entrevistas de validação do estudo empírico................ 198

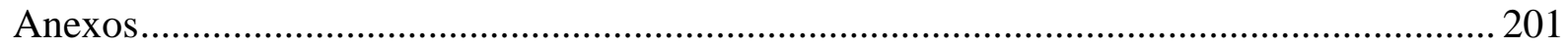

Anexo A - DVAs com distribuição de valor adicionado para comunidade ...................... 202 Anexo B - Tabela original de Garriga e Melé (2004, p. 63-64) e referências citadas pelos

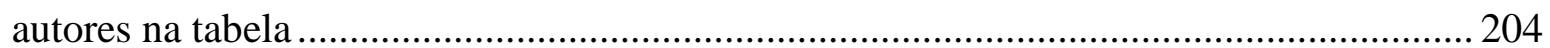

Anexo C - Tabela original de Freeman e Reed (1983, p. 94) .......................................... 208

Anexo D - Modelo Ibase de Balanço Social para empresas em geral .............................. 208

Anexo E - Modelo de DVA para empresas em geral - CPC n. ${ }^{\circ}$ 09/2008 ......................... 211

Anexo F - Contas Econômicas Integradas 2006 (IBGE, 2008b) ..................................... 212

Anexo G - Tabela de Recursos e Usos 2006 (IBGE, 2008b) .......................................... 217

Anexo H - DVA da empresa Votorantim Celulose e Papel S.A. ...................................... 221

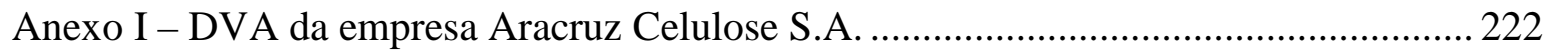




\section{LISTA DE ABREVIATURAS E SIGLAS}

CEI - Contas Econômicas Integradas

CFC - Conselho Federal de Contabilidade

CNAE - Classificação Nacional de Atividades Econômicas

CPC - Comitê de Pronunciamentos Contábeis

CVM - Comissão de Valores Mobiliários

DIPJ - Declaração de Informações Econômico-fiscais da Pessoa Jurídica

DRE - Demonstração do Resultado do Exercício

DVA - Demonstração do Valor Adicionado

FIPECAFI - Fundação Instituto de Pesquisas Contábeis, Atuariais e Financeiras

FMDCA - Fundo Municipal dos Direitos da Criança e do Adolescente

GRI - Global Reporting Iniciative

IASB - International Accounting Standards Board

IBGE - Instituto Brasileiro de Geografia e Estatística

IPEA - Instituto de Pesquisa Econômica Aplicada

ISFL - Instituições sem Fins de Lucro

PAC - Pesquisa Anual do Comércio

PAIC - Pesquisa Anual da Indústria da Construção

PAS - Pesquisa Anual de Serviços

PIA - Pesquisa Industrial Anual

PIB - Produto Interno Bruto

PIL - Produto Interno Líquido

RND - Renda Nacional Bruta

RNDB - Renda Nacional Disponível Bruta

RSC - Responsabilidade Social Corporativa

SNA - System of National Accounts

TRU - Tabela de Recursos e Usos 


\section{LISTA DE QUADROS}

Quadro 1 - Modelo de DVA adotado no Brasil até 2007 .................................................... 10

Quadro 2 - Teorias de Responsabilidade Social Corporativa e abordagens relacionadas....... 23

Quadro 3 - Comparação dos conceitos de RSC, Cidadania Corporativa e Cidadania do

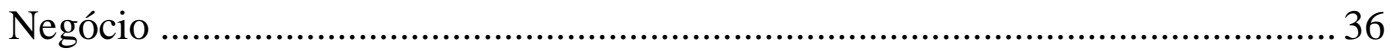

Quadro 4 - Mapa dimensional dos stakeholders: poder $\mathrm{x}$ interesse ...................................... 41

Quadro 5 - Modelo FIPECAFI x Modelo CFC de DVA........................................................ 72

Quadro 6 - Tabela de Valor Econômico Gerado e Distribuído - EVG\&D - pelo GRI............ 88

Quadro 7 - Exemplos de indicadores de avaliação de desempenho baseados na DVA, propostos por SANTOS (2003, p. 219-228)..................................................... 93

Quadro 8 - Vantagens e Limitações da DVA conforme síntese da literatura...........................99

Quadro 9 - Categorias e subcategorias definidas na questão C6 para classificação do

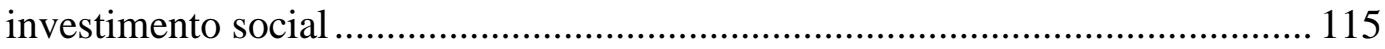

Quadro 10 - Tipologia Final das Informações do Relatório de Sustentabilidade................... 134

Quadro 11 - Tipologia Final dos Dispêndios realizados nos Investimentos Socioambientais

Quadro 12 - Tipologia Final dos Meios de Transferência de Recursos nos Investimentos

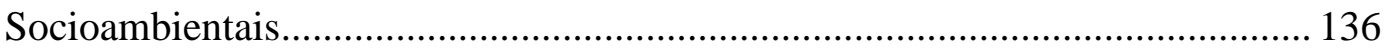

Quadro 13 - DVA dividida em Formação e Distribuição de Valor Adicionado .................... 138

Quadro 14 - Tipologia das informações na categoria Meio Ambiente.................................. 139

Quadro 15 - Tipologia das informações na categoria Comunidade ..................................... 141

Quadro 16 - Estrutura parcial das Contas Econômicas Integradas....................................... 149

Quadro 17 - Tipologia Final dos Meios de Transferência de Recursos nos Investimentos Socioambientais. 


\section{LISTA DE TABELAS}

Tabela 1 - Demonstração do Valor Adicionado da empresa Edison na Itália - 2006

Tabela 2 - Investimento Social Privado, por região: montante de recursos investidos e

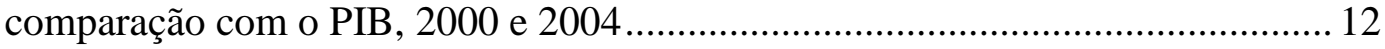

Tabela 3 - Número de DVAs encontradas por tipo de apresentação ..................................... 66

Tabela 4 - Exemplo de valor adicionado ao longo da cadeia produtiva ................................ 67

Tabela 5 - Simulação de DVA com investimentos sociais destacados como distribuição de VA

Tabela 6 - Caracterização da amostra de empresas analisadas no estudo empírico 109

Tabela 7 - Dados de caracterização da amostra coletados na parte A do roteiro de avaliação dos relatórios 110

Tabela 8 - Dados de caracterização da amostra coletados na parte B do roteiro de avaliação dos relatórios 111

Tabela 9 - Classificação das informações divulgadas nos relatórios quanto à qualidade da informação 


\section{LISTA DE GRÁFICOS}

Gráfico 1 - Número de empresas que publicaram a DVA no período de 1997-2006 .............. 9

Gráfico 2 - Gráfico das atividades que receberam ações sociais das empresas .................... 102

Gráfico 3 - Gráfico dos motivos pelos quais as empresas realizaram ações sociais ............. 102

Gráfico 4 - Análise da presença da DVA nos relatórios analisados ..................................... 113

Gráfico 5 - Distribuição das informações divulgadas entre as categorias de sustentabilidade

Gráfico 6 - Distribuição das informações de Recursos Humanos entre suas subcategorias . 119

Gráfico 7 - Distribuição das informações de Meio Ambiente entre suas subcategorias ........ 120

Gráfico 8 - Distribuição das informações de Relações com a Comunidade entre suas

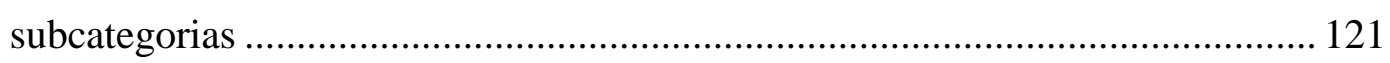

Gráfico 9 - Distribuição das informações de Consumidores entre suas subcategorias .......... 122

Gráfico 10 - Distribuição das informações sobre a Empresa entre suas subcategorias.......... 123

Gráfico 11 - Classificação das informações conforme o relacionamento da prática social com o processo produtivo da companhia 125

Gráfico 12 - Classificação das informações conforme o relacionamento da prática social com o processo produtivo da companhia, por categoria 126

Gráfico 13 - Classificação das informações conforme o dispêndio da companhia, por categoria 127

Gráfico 14 - Classificação das informações conforme o meio de transferência de recursos 128 


\section{INTRODUÇÃO ${ }^{1}$}

A Responsabilidade Social Corporativa (RSC) é uma prática que beneficia a sociedade. Ainda não há um consenso sobre a definição de RSC. Alguns autores defendem que a empresa que atua de forma ética, sem prejudicar o meio ambiente ou lesar os empregados, por exemplo, é socialmente responsável. Outros defendem que a empresa deve realizar investimentos na sociedade além de atuar eticamente. Em qualquer uma das visões, a RSC significa se preocupar com os stakeholders ${ }^{2}$ e prestar contas a eles.

A prestação de contas aos stakeholders pode ser realizada publicamente, por exemplo, com a divulgação de relatórios sociais, ou apenas mediante regulamentações, por exemplo, com a obtenção de um Estudo de Impactos Ambientais (EIA) ou Relatório de Impactos Ambientais (RIMA) antes da instalação de um novo projeto. Existem diversas maneiras de se prestar contas à sociedade, mas esta tese aborda apenas as formas de publicação para usuário externo, mais especificamente os relatórios com cunho social publicados pelas companhias.

Tinoco (2006) coloca o Balanço Social como uma maneira de prestar contas a uma sociedade direta ou indiretamente afetada pelas ações da empresa. $\mathrm{O}$ autor afirma que as organizações vivem em função da sociedade, pois "consomem recursos naturais, renováveis ou não, direta ou indiretamente, que constituem parte integrante do patrimônio da humanidade" e "utilizam recursos humanos, físicos e tecnológicos, que pertencem a pessoas e portanto à sociedade" (p. 28).

O Balanço Social é formado por quatro vertentes: recursos humanos, recursos ambientais, valor adicionado à sociedade e relação com a comunidade. A primeira trata a relação da empresa com seus empregados, por isso se foca no ambiente interno da organização. A segunda focaliza a sustentabilidade dos recursos naturais, ou seja, a ação da empresa não deve prejudicar o meio ambiente, nem agora nem no futuro. A terceira mostra a contribuição da

\footnotetext{
${ }^{1}$ Este texto foi revisado de acordo com a Ortografia da Língua Portuguesa (1990), em vigor a partir de $1^{\circ}$ de janeiro de 2009.

${ }_{2}^{2}$ Freeman e Reed (1983, p. 89) definem stakeholders como grupos com interesse nas ações da empresa e sem os quais ela não conseguiria existir: acionistas, empregados, clientes, fornecedores, credores e sociedade. O termo é utilizado nos trabalhos acadêmicos brasileiros sem tradução.
} 
empresa para a geração de riqueza no país e como essa riqueza é distribuída. Por fim, a vertente de relação com a comunidade evidencia como a empresa se relaciona com a comunidade local e foca-se no ambiente externo da empresa (FUNDAÇÃO INSTITUTO DE PESQUISAS CONTÁBEIS, ATUARIAIS E FINANCEIRAS, 2007, p. 10).

A Demonstração do Valor Adicionado (DVA), parte do Balanço Social, é uma demonstração contábil com o objetivo de "evidenciar a contribuição da empresa para o desenvolvimento econômico-social da região onde está instalada, discriminando o que a empresa agrega de riqueza à economia local e, em seguida, a forma como distribui tal riqueza" (SANTOS, 2003, p. 11). É uma demonstração voltada para a sociedade, pois mostra como a empresa remunera os stakeholders e não apenas os acionistas. A distribuição de valor adicionado remunera os empregados, o governo, o capital de terceiros e o capital próprio.

\begin{abstract}
Valor Adicionado representa a riqueza total da firma que poderia ser distribuída para todos os provedores de capital, empregados e governo. Lucro representa o retorno para os acionistas enquanto os outros componentes do valor adicionado refletem o retorno para os outros stakeholders, isto é, governo, credores e empregados. (EVRAERT; RIAHI-BELKAOUI, 1998, p. 1 , tradução livre $)^{3}$.
\end{abstract}

A DVA, objeto de estudo deste trabalho, tornou-se uma demonstração contábil de publicação obrigatória para as companhias brasileiras de capital aberto com a promulgação da Lei Ordinária $\mathrm{n}^{\circ}$ 11.638/2007 que trouxe mudanças para a chamada 'Lei das Sociedades Anônimas'. Muitas dessas mudanças tinham por objetivo facilitar o processo de adoção das normas contábeis internacionais no Brasil.

O processo de harmonização das normas contábeis ocorre em diversos países, e o Brasil se propôs a realizá-lo, majoritariamente, até 2010. O objetivo desse processo é desenvolver um conjunto de padrões internacionais de contabilidade. O International Accounting Standards Comitee (IASC), de 1973 a 2001, e o International Accounting Stardards Board (IASB), a partir de 2001, emitiram pronunciamentos contábeis que deverão ser adotados pelos países que participam da harmonização internacional. O Brasil, nos últimos cinco anos, evoluiu bastante nesse processo, principalmente com a criação do Comitê de Pronunciamentos Contábeis (CPC) que vem emitindo normas em convergência com os padrões internacionais

\footnotetext{
${ }^{3}$ Value added represents the total wealth of the firm that could be distributed to all capital providers, employees and the government. Earnings represents the return to shareholders while other value added components reflect returns to the other stakeholders - i.e. the government, bondholders and employees. (EVRAERT; RIAHIBELKAOUI, 1998, p. 1)
} 
para serem aprovadas pelos órgãos reguladores: Comissão de Valores Mobiliários (CVM), Banco Central do Brasil, Instituto dos Auditores Independentes do Brasil (Ibracon), Superintendência dos Seguros Privados (SUSEP), entre outros.

Com a aprovação da obrigatoriedade da DVA no Brasil, o CPC emitiu um pronunciamento sobre a estrutura e elaboração da nova demonstração. Entretanto, muitas empresas já publicavam a DVA (Gráfico 1). Vale destacar a importante contribuição da Fundação Instituto de Pesquisas Contábeis, Atuariais e Financeiras (FIPECAFI) para a consolidação da DVA no Brasil. A FIPECAFI é responsável pela classificação das empresas no anuário 'Melhores e Maiores' da Revista EXAME (Editora Abril) e instituiu, a partir de 1998, a DVA como um dos quesitos a serem pontuados para tal classificação (SANTOS; CARVALHO, 1997, p. 132). Sem dúvida, esse foi um dos fatores para o crescimento da publicação, conforme exposto no Gráfico 1.

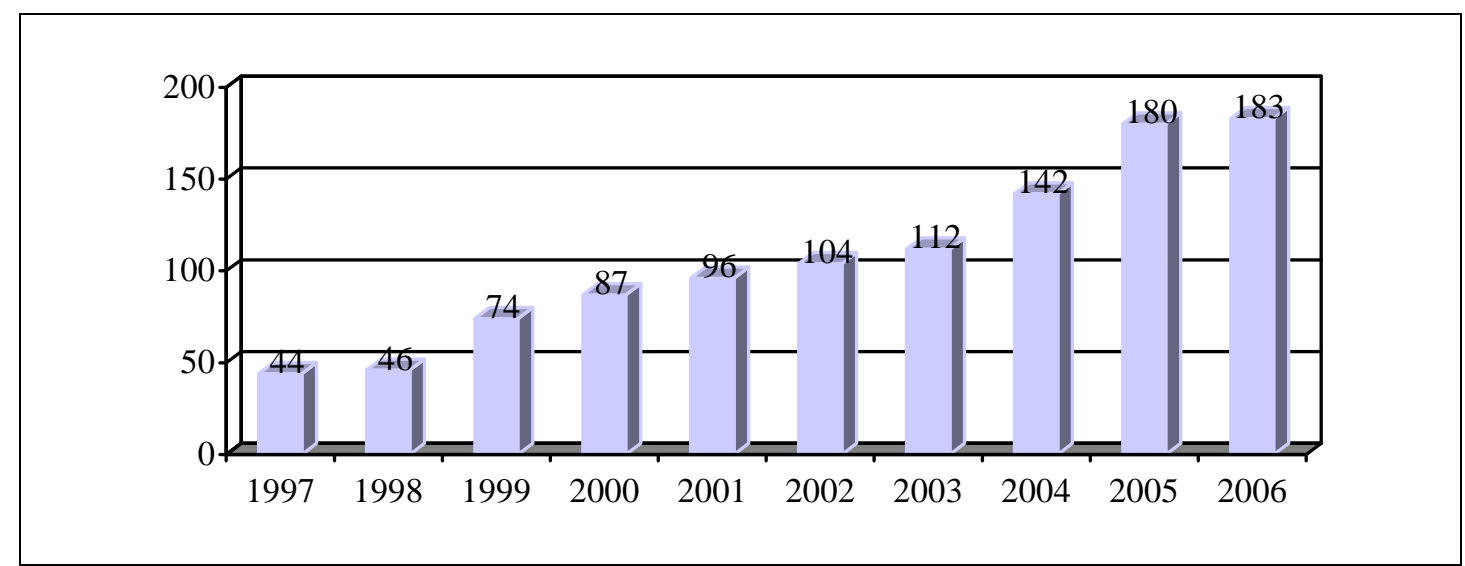

Gráfico 1 - Número de empresas que publicaram a DVA no período de 1997-2006 FONTE: Informações do banco de dados Melhores e Maiores cedidas por FIPECAFI

As informações da DVA são relevantes para a relação da empresa com a sociedade. Prova disso são os modelos de Balanço Social mais adotados pelas empresas (Ibase e GRI - cujos relatórios serão discutidos no capítulo 2), eles incluem a publicação da riqueza gerada pela empresa e sua distribuição. As informações de cunho social não são obrigatórias no Brasil, mas diversas empresas de capital aberto divulgam alguma forma de relatório social.

Assim também acontece em muitos outros países. Apesar de a DVA não ser uma demonstração recomendada pelas normas do IASB, empresas a divulgam em diferentes países (OLIVEIRA, 2008). A postura do IASB é evasiva com relação a tal questão. No International Accounting Stardards (IAS) $\mathrm{n}^{\mathrm{o}} 1$, sobre a apresentação das demonstrações financeiras, o 
comitê se mostra consciente da prática de disclosure social, mas afirma que os relatórios sociais estão fora do seu escopo, formado apenas pelas demonstrações financeiras (IAS 1, 2007, p. 12). Cabe ressaltar que a DVA é elaborada com informações contábeis e, portanto, apesar do cunho social, pode ser considerada uma demonstração financeira.

\begin{abstract}
A DVA, elaborada a partir dos registros da Contabilidade, portanto, com os padrões estabelecidos pelos Princípios Fundamentais de Contabilidade, tem enfoque bastante diferente das demonstrações tradicionais. Mesmo sendo baseada nas informações da Demonstração de Resultado do Exercício - DRE -, não deve ser confundida com esta, pois a DVA tem conteúdo e abrangência mais socializados. (SANTOS, 1999, p. 266).
\end{abstract}

No contexto de harmonização dos padrões contábeis internacionais, é importante comparar a publicação da DVA no Brasil com outros países (ver OLIVEIRA, 2008). Entre as diferenças encontradas nessa comparação, uma em especial destacou-se por ser divergente da estrutura adotada no Brasil (Quadro 1) e por não ser uma discussão recorrente na academia: investimentos sociais considerados como distribuição do valor adicionado pela empresa.

Quadro 1 - Modelo de DVA adotado no Brasil até 2007

\begin{tabular}{|ll|}
\hline 1. & RECEITAS \\
1.1 & Vendas de mercadorias, produtos e serviços \\
1.2 & Provisão para devedores duvidosos \\
2.3 & Não operacionais \\
2.1 & INSUMOS ADQUIRIDOS DE TERCEIROS \\
2.2 & Custorias-primas consumidas \\
2.3 & Materiais, energia, serviços de terceiros e outros \\
2.4 & Perda / Recuperação de valores ativos \\
3 & VALOR ADICIONADO BRUTO (1 - 2) \\
4 & RETENÇÕES \\
4.1 & Depreciação, amortização e exaustão \\
5 & VALOR ADICIONADO LÍQUIDO PRODUZIDO PELA ENTIDADE (3-4) \\
6 & Valor Adicionado recebido em transferência \\
6.1 & Resultado da equivalência patrimonial \\
6.2 & Receitas financeiras \\
7 & VALOR ADICIONADO TOTAL A DISTRIBUIR (5 + 6) \\
8 & DISTRIBUIÇÃO DO VALOR ADICIONADO $(8=7)$ \\
8.1 & Pessoal e Encargos \\
8.2 & Impostos, taxas e contribuições \\
8.3 & Juros e aluguéis \\
8.4 & Juros sobre capital próprio e dividendos \\
8.5 & Lucros retidos / Prejuízo do exercício \\
\hline
\end{tabular}

FONTE: SANTOS, 2003, p. 39 (adaptado).

Alguns dos casos nessa situação são: Unilever no Reino Unido (2006), Centrica também no Reino Unido (2006), Edison na Itália (2006) e Singapore Press Holdings em Singapura (2006). A Tabela 1 ilustra a situação com a DVA da empresa Edison destacando a distribuição de valor adicionado para a comunidade (as outras demonstrações citadas estão 
expostas no Anexo A). Na estrutura adotada no Brasil (Quadro 1), os investimentos sociais, contabilizados como despesas operacionais, figuram na DVA como uma redução do valor adicionado pela empresa, ou seja, como insumos adquiridos de terceiros.

Tabela 1 - Demonstração do Valor Adicionado da empresa Edison na Itália - 2006 Prospetto analitico di determinazione del valore aggiunto globale (milioni di euro)

\begin{tabular}{|c|c|c|}
\hline & 2005 & 2006 \\
\hline & (IAS/IFRS) & (IAS/IFRS) \\
\hline \multicolumn{3}{|l|}{ A) Valore della produzione } \\
\hline Ricavi delle vendite e delle prestazioni & $6.405,36$ & $8.489,34$ \\
\hline Variazione delle rimanenze di prodotti in corso, semilavorati e prodotti & 20,57 & 73,99 \\
\hline Variazioni di lavori in corso su ordinazione & 7,36 & -1 \\
\hline Incrementi di immobilizzazioni per lavori interni & 9,28 & 14,44 \\
\hline Altri ricavi & 561,27 & 775,36 \\
\hline Totale dei ricavi della produzione tipica & $6.989,12$ & $9.352,54$ \\
\hline Ricavi per produzioni atipiche (costruzioni in economia) & - & - \\
\hline Valore globale della produzione & $6.989,12$ & $9.352,54$ \\
\hline \multicolumn{3}{|l|}{ B) Costi intermedi della Produzione } \\
\hline Consumi di materie e servizi (voci B6 - B7 - B8 - B11 - B14 CE) & $5.452,92$ & $7.560,61$ \\
\hline Accantonamenti per rischi (12) & 28,32 & 40,12 \\
\hline Altri accantonamenti (13) & 8,83 & 1,98 \\
\hline Costi intermedi della produzione & $5.490,07$ & $7.602,71$ \\
\hline Valore aggiunto caratteristico lordo & $1.499,05$ & $1.749,83$ \\
\hline \multicolumn{3}{|l|}{ C) Componenti straordinari ed accessori } \\
\hline Proventi finanziari & - & - \\
\hline Altri proventi (oneri) netti & 6,54 & 4 \\
\hline Ricavi accessori - Costi accessori & 6,54 & - \\
\hline Ricavi straordinari - Costi straordinari (voce E CE) & 93,15 & 166,27 \\
\hline Valore aggiunto globale lordo & $1.598,73$ & $1.920,10$ \\
\hline Ammortamenti e svalutazioni & 670,01 & 803,33 \\
\hline Valore aggiunto globale netto & 928,73 & $1.116,77$ \\
\hline \multicolumn{3}{|l|}{ Riparto del valore aggiunto (milioni di euro) } \\
\hline & 2005 & $\overline{2006}$ \\
\hline a) Personale & 199,73 & 203,37 \\
\hline b) Pubblica amministrazione & 9,23 & 7,07 \\
\hline \multicolumn{3}{|l|}{ c) Remunerazione del capitale di credito } \\
\hline (Oneri finanziari) & 215,59 & 246,31 \\
\hline d) Remunerazione azienda & 502,93 & 474,5 \\
\hline \multicolumn{3}{|c|}{ e) Remunerazióne_capitale_di rischchio $\ldots$} \\
\hline f) Liberalità & 0,37 & 0,44 \\
\hline 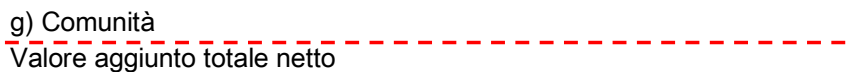 & $\begin{array}{r}0,89 \\
-\overline{92} \overline{8}, \overline{74}\end{array}$ & $-\frac{2,07}{1 . \overline{1} \overline{1} \overline{7}, \overline{7} \overline{7}}$ \\
\hline
\end{tabular}

FONTE: EDISON, 2006 (destaque da autora)

À primeira vista, essa pode parecer uma questão puramente normativa sobre qual a linha da DVA mais adequada para classificar os investimentos sociais. Entretanto, a questão é mais complexa, pois se trata da contribuição da empresa para a produção do país. O produto nacional, produção do país em determinado período, pode ser calculado como a somatória do valor adicionado pelos produtores a tudo o que foi produzido pelo país no período. 
O valor adicionado é a diferença entre as vendas da empresa e as suas compras de matériasprimas e de serviços de outras empresas. O uso do valor adicionado para o cálculo do produto nacional justifica-se por evitar dupla contabilização dos produtos intermediários (SAMUELSON; NORDHAUS, 1993, p. 487).

A produção do país também pode ser calculada por meio da renda, dada a igualdade da macroeconomia entre produção e renda. Renda é definida como a remuneração dos fatores de produção: capital e trabalho.

A identidade PRODUTO = RENDA resulta de que a adição de valores, em cada etapa da produção, corresponde exatamente à remuneração de fatores, pelo pagamento de salários, juros, lucros, aluguéis, impostos e rendas ao exterior. Os dois últimos itens representam, no caso, a renda do Governo e a do resto do mundo. Como o produto é o total dos valores adicionados e a renda o total das remunerações de fatores, segue-se a identidade em questão. (SIMONSEN e CYSNE, 2007, p.148).

Essa identidade entre produto e renda é apresentada na DVA, pois o Valor Adicionado Total é igual ao total da Distribuição do Valor Adicionado (linhas 7 e 8 do Quadro 1). Assim, a questão dos investimentos sociais alocados como distribuição ou formação de valor adicionado tem relação direta com o cálculo do produto nacional, apesar do mesmo ser estimado. A Tabela 2 mostra os volumes investidos pelas empresas em ações sociais. Por esse dado, se o produto nacional fosse calculado pela somatória dos valores adicionados divulgados nas DVAs, a forma de contabilizar os investimentos sociais poderia alterar o produto nacional em 4,7 bilhões de reais.

Tabela 2 - Investimento Social Privado, por região: montante de recursos investidos e comparação com o PIB, 2000 e 2004

\begin{tabular}{l|c|cc}
\hline \multirow{2}{*}{ Região } & \multirow{2}{*}{$\begin{array}{c}\text { Recursos Investidos, } \\
\text { em 2004 (em R\$) }\end{array}$} & \multicolumn{2}{|c}{$\begin{array}{c}\text { Recursos Investidos em } \\
\text { Relação ao PIB (\%) }\end{array}$} \\
\cline { 3 - 4 } & 3,3 bilhões & 2000 & 2004 \\
\hline Sudeste & 537 milhões & 0,66 & 0,34 \\
Nordeste & 562,7 milhões & 0,19 & 0,22 \\
Sul & 240,8 milhões & 0,16 & 0,19 \\
Centro-Oeste & 93,8 milhões & 0,10 & 0,18 \\
Norte & $\mathbf{4 , 7}$ bilhões & $\mathbf{0 , 4 3}$ & $\mathbf{0 , 2 7}$ \\
Brasil & \multicolumn{3}{c}{ FONTE: Pesquisa Ação Social das Empresas no Brasil (IPEA, 2006, p) }
\end{tabular}

A discussão sobre como alocar os investimentos sociais na DVA - formação ou distribuição de valor adicionado - está diretamente relacionada ao conceito de Responsabilidade Social Corporativa, pois é necessário avaliar se os investimentos sociais são sacrifícios para geração 
de receita ou se constituem distribuição de valor adicionado para a comunidade. O capítulo 2 trará as diversas teorias que explicam as ações de responsabilidade social da empresa.

Uma das linhas de estudo da RSC baseia-se na teoria de maximização do valor para o acionista como objetivo das empresas. Por essa teoria a empresa deveria realizar apenas os investimentos sociais que maximizassem o valor da empresa para os acionistas e não poderia, portanto, investir em projetos que representassem apenas um custo para o negócio. Nesse sentido, Friedman (1970) afirma que empresas não são pessoas, por isso não têm responsabilidades, "apenas pessoas podem ter responsabilidades". Os administradores têm a responsabilidade de usar recursos e energia da empresa apenas em atividades destinadas a aumentar os lucros de seus empregadores. Segundo esse autor, não compete aos administradores determinar se, onde e quanto deve ser investido em questões sociais. De acordo com esse autor, qualquer decisão nesse sentido, tomada pelos gestores, implica em custos injustos para acionistas, empregados e clientes.

Por essa linha de estudo, qualquer investimento social seria um esforço para geração de receita para a empresa, portanto seria redução na formação do valor adicionado como está previsto na estrutura da DVA adotada no Brasil.

Entretanto, uma outra linha de estudo da RSC defende a "cidadania corporativa", isto é, a empresa atua com ações sociais nos pontos em que o governo falha, "em proteção da cidadania" (MATTEN; CRANE; CHAPPLE, 2003, p. 116). Essa ótica deriva da transição do governo provedor (Welfare State) para o governo regulador (Estado Mínimo) que divide (ou delega totalmente) as tarefas de assistência social com o mercado (GRAY; KOUHY; LAVERS, 1995, p. 62). Nessa linha, as empresas cumprem o papel de Estado quando realizam investimentos sociais.

Se a empresa realiza o papel do governo quando faz investimentos sociais, então, ela estaria gerando valor para a comunidade e não agindo em prol de interesses próprios? Assim, se a empresa distribui valor adicionado quando paga impostos, também estaria distribuindo valor adicionado quando age como governo.

Nesse contexto, justifica-se estudar os investimentos sociais das empresas com o objetivo de identificar em quais situações os mesmos constituem-se como distribuição de valor 
adicionado, ou seja, identificar em quais condições os investimentos sociais caracterizam-se como distribuição de renda e em quais delas os investimentos sociais são apenas esforços para geração de receitas (redução na formação de valor adicionado).

\subsection{Caracterização do problema}

Baseado no contexto exposto anteriormente, o problema de pesquisa deste trabalho foi formulado pela seguinte questão: em quais condições os investimentos sociais empresariais podem ser considerados distribuição de valor adicionado?

Esse problema propõe o estudo das variáveis investimento social e valor adicionado. A definição operacional de investimento social neste trabalho será: gastos de empresas com ações sociais e ambientais declarados em seu Relatório Social ou Relatório de Sustentabilidade. Valor adicionado será definido como "o valor que a atividade agrega aos bens e serviços consumidos no seu processo produtivo. É a contribuição ao produto interno bruto pelas diversas atividades econômicas, obtida pela diferença entre o valor de produção e o consumo intermediário absorvido por essas atividades." (IBGE, 2008a, p. 166).

\subsection{Objetivos da pesquisa}

Assim, o objetivo geral desta pesquisa é identificar em quais condições as empresas podem considerar seus investimentos sociais como distribuição de valor adicionado.

São os seguintes os objetivos específicos:

1. analisar a literatura de responsabilidade social e Demonstração do Valor Adicionado;

2. analisar o problema de pesquisa sob a ótica conceitual, especialmente com as definições econômicas relacionadas ao tema;

3. tipificar os investimentos sociais realizados por uma amostra de empresas;

4. analisar como os investimentos sociais tipificados são contabilizados no cálculo do PIB. 


\subsection{Metodologia}

A orientação metodológica deste trabalho é o estruturalismo. Essa perspectiva epistemológica aplicada às ciências sociais caracteriza-se por estudar as relações entre os elementos sociais e explicá-las por um conjunto de estruturas sociais. "Um traço fundamental do estruturalismo é a concepção de que o conhecimento da realidade somente torna-se possível quando são identificadas suas formas subjacentes e invariantes" (MARTINS; THEÓPHILO, 2007, p. 43).

O geral, abstraído dos casos particulares, tem a capacidade de cobrir a todos e por isso não é nenhum deles, assumindo posição de referência invariante. A potência explicativa se liga exatamente à invariância, realizando sonho positivista persistente: a constituição de parâmetros formais estáveis de conhecimento, de tal sorte que se tornaria factível concretizar os ideais caros da objetividade, da certeza, da evidência, da verdade.

Assim, se a ciência lida com o nível geral da realidade e se este geral não pode logicamente provir da acumulação de particularidades, o estruturalismo oferece solução lógica: o geral faz parte da estrutura mental, consiste em formas invariantes, "já dadas"; independem do concreto. A ciência não explica o concreto individual, porque, se assim fosse, necessitaríamos de uma nova ciência para cada novo concreto individual, que, por definição, não se repete. (DEMO, 2007, p. 173).

A metodologia de pesquisa deste trabalho está fundamentada em três fases, conforme os procedimentos de uma análise estruturalista (RICHARDSON, 1999, p. 42-43). A Ilustração 1 apresenta as fases propostas. A fase 1 visa a pesquisar estudos anteriores relacionados ao tema. As fases 2 e 3 são etapas do estudo empírico a ser realizado.

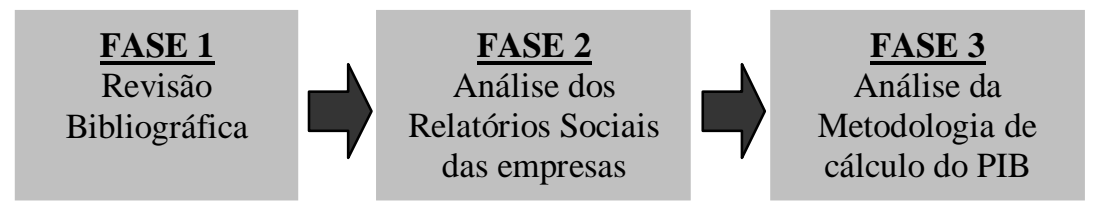

Ilustração 1 - Fases da Pesquisa

A fase 2 tem o objetivo de identificar os tipos de investimentos realizados por uma amostra de empresas, ou seja, decompor o fenômeno estudado em busca de elementos invariantes que deverão compor a estrutura proposta. Será realizada análise de conteúdo em relatórios publicados por empresas de capital aberto. Será utilizado um corte transversal das empresas que realizaram investimentos sociais e apresentaram Balanço Social ou Relatório de Sustentabilidade referente a 2007. A amostra será intencional com o objetivo de formar um grupo diversificado, possibilitando a identificação de uma maior variedade de tipos de 
investimentos sociais. O produto dessa fase é uma relação de elementos invariantes dos investimentos sociais para investigar, na próxima fase, como esses investimentos se relacionam com o conceito de valor adicionado. Haverá entrevista de validação da estrutura resultante dessa fase com profissionais que pesquisam ações sociais e ambientais de empresas.

A fase 3 tem o objetivo de identificar como os elementos relacionados na etapa anterior são computados (ou se são computados) no cálculo do valor adicionado. Inicialmente será realizada análise baseada no conceito de valor adicionado, e, posteriormente, a análise terá o cálculo do PIB brasileiro como referência. Para isso, será utilizada análise documental das Notas Metodológicas sobre o cálculo do PIB divulgadas pelo Instituto Brasileiro de Geografia e Estatística (IBGE). O produto desta fase será a resposta ao problema de pesquisa e a caracterização dos investimentos socioambientais que podem ser classificados como distribuição de valor adicionado (se houver). Haverá, ao final dessa fase, entrevista com o chefe das Contas Nacionais do IBGE para validar os resultados encontrados.

\subsection{Desenvolvimento da pesquisa}

O desenvolvimento do trabalho escrito está organizado em mais cinco capítulos. Após esta introdução com o tema da pesquisa e a contextualização do problema a ser estudado, será exposta a revisão da literatura. O capítulo 2 faz um mapeamento da literatura sobre Responsabilidade Social Empresarial e o capítulo 3 discute os conceitos relacionados à Demonstração do Valor Adicionado.

Os capítulos 4 e 5 mostram o estudo empírico visando a responder ao problema de pesquisa. O quarto capítulo traz a análise dos investimentos sociais de uma amostra de empresas e compõe uma tipificação das ações de responsabilidade social divulgadas nos relatórios analisados. O quinto capítulo relaciona os investimentos sociais com o conceito de valor adicionado. E, ainda, analisa como os investimentos sociais levantados no capítulo 4 são computados na metodologia de cálculo do PIB brasileiro.

O capítulo 6 trará as considerações finais e conclusões da pesquisa. Espera-se como resultado desta pesquisa contribuir para a evidenciação dos investimentos socioambientais realizados 
pelas empresas na Demonstração do Valor Adicionado e para a discussão sobre a avaliação dos investimentos socioambientais realizados pelas empresas. É importante que os relatórios sociais sejam objeto de análise pela sociedade e não apenas peças de marketing com informações descritivas e pouco informativas que vêm sendo divulgadas pelas organizações.

\subsection{Limitações da pesquisa}

Inicialmente, destacam-se duas limitações inerentes à pesquisa estruturalista. A primeira é o empobrecimento da realidade, consequência da simplificação dos fenômenos em modelos estruturais que também podem levar a ignorar a possibilidade de transformação desses fenômenos. A segunda é a possibilidade de o pesquisador "cair em um pré-determinismo negativo para as transformações sociais" (RICHARDSON, 1999, p. 43).

A pesquisa empírica analisará os Relatórios de Sustentabilidade, documento não obrigatório e, em sua maioria, não auditado. Assim, outra limitação aparece pelo documento utilizado na pesquisa, pois pode haver informações distorcidas, prejudicando a validade interna da pesquisa. Como esse é o documento mais apropriado para o estudo, optou-se por utilizá-lo, apesar da limitação.

Deve-se destacar que o trabalho não avalia, em nenhuma vertente, a existência de distribuição igualitária da renda. Essa análise seria possível apenas se os impactos da ação social fossem mensurados pelas empresas. 



\section{RESPONSABILIDADE SOCIAL}

Este capítulo tem por objetivo abordar as teorias que explicam as práticas de responsabilidade empresarial. Inicialmente discutir-se-á a responsabilidade social das empresas como resposta às falhas do Estado. Em seguida, haverá uma exposição das principais teorias sobre Responsabilidade Social Corporativa (RSC). Por fim, serão vistos os principais relatórios que mostram as práticas socioambientais das empresas.

Garriga e Melé (2004, p. 51) apontam o livro 'Social Responsibilities of Businessman' de Howard Bowen divulgado em 1953 como o marco inicial do intenso debate sobre Responsabilidade Social. Desde então uma grande variedade de terminologias surgiu. Carroll (1994, p. 14) analisa a pesquisa em responsabilidade social e constata um campo de estudos eclético, pouco focado e com discussões pobres, mas que vem aumentando o nível crítico dos textos e incrementando as técnicas de pesquisa.

Alguns trabalhos, especialmente os nacionais, colocam a responsabilidade social como uma resposta da sociedade às falhas do Estado (entre deles: Gray, Kouhy e Laver, 1995a; Matten, Crane e Chapple, 2003; Freitas, 2000; Bittencourt e Carrieri, 2005; Fontanelle, 2006; Passador e Ferraz, 2007). Por isso, este capítulo se inicia com uma discussão sobre as responsabilidades do Estado.

Com o fim da Guerra Fria e o declínio do socialismo em todo o mundo, a partir da década de 1980, ideias alternativas de sociedade começaram a brotar. Paralelamente, duas crises concomitantes - a da sociedade do trabalho e a dos Welfare States (Estados de Bem-Estar Social) - influenciaram a reflexão de intelectuais e militantes políticos quanto a que ideal de sociedade buscar (JUSTO, 2007, p.17).

\footnotetext{
Desde meados dos anos 1970, com o fim dos chamados anos gloriosos do capitalismo (que se iniciaram após a segunda grande guerra), o mundo vem passando por uma série de transformações econômicas, políticas e sociais. Em âmbito econômico, a crise do petróleo, o desenvolvimento acelerado do mercado financeiro e dos processos de inovação tecnológica e organizacional, juntamente com o crescimento da instabilidade econômica que os governos passaram a enfrentar (com crescente comprometimento das finanças públicas) trouxeram de volta o problema do desemprego e da sustentação de renda das camadas desfavorecidas no processo de produção da riqueza, que havia sido contornado no período de auge dos Welfare States. Recolocou-se, então,
} 
para os governos nacionais, a questão da viabilidade da vinculação entre crescimento econômico e distribuição de renda, em que se apoiavam os modelos de Estado de Bem-Estar Social. Em termos sociais, o recurso a formas mais precárias de trabalho, como o emprego parcial, temporário, a subcontratação, a flexibilização da jornada e a desregulamentação do trabalho, que vieram no rastro dos processos de reestruturação produtiva, aumentou a insegurança das pessoas e, com isso, a demanda por políticas sociais. O contraditório deste processo é que justamente quando cresceram as pressões sobre tais políticas, também se complicaram as suas fontes de financiamento (DRAIBE, 1990: 20), exigindo do Estado reflexão e tentativas de reformulação das mesmas. Finalmente, em âmbito político, a legitimidade das políticas sociais passou a ser questionado, conforme começaram a se expandir as idéias neoliberais de emagrecimento do Estado. (JUSTO, 2007, p. 17-18).

Nesse contexto, a ideia de Estado Mínimo, em oposição ao Welfare State, se fortalece. O conceito de Estado Mínimo baseia-se na descentralização do governo, com a redução do Estado provedor, e no fortalecimento do mercado, considerado eficiente alocador de recursos. Segundo Pereira (1998, p. 31), esse conceito é caracterizado pela liberalização comercial e programas de privatização. O governo deve agir apenas nas falhas do mercado. Mas esse modelo, no formato radical neoliberal, também foi bastante criticado.

As sociedades democráticas contemporâneas, embora sabendo das falhas da ação dos governos, não estão dispostas a aceitar os desequilíbrios econômicos e sociais que as falhas do mercado provocam. Sabem que o Estado, e os governos que o dirigem, não está isento de cometer suas próprias falhas, mas não aceitam a tese neoconservadora de que as falhas do mercado, embora existentes, são sempre menos graves do que as falhas do Estado, e preferem correr esse risco a ficar na total dependência das forças do mercado. Este último é um excelente mecanismo de alocação de recursos, mas distribui mal a renda. (PEREIRA, 1998, p. 32).

Para Rosanvallon (1997, apud JUSTO, 2007, p. 375), a crise do Estado protetor é de caráter cultural e sociológico: por trás do impasse financeiro, o problema fundamental a ser resolvido diz respeito ao reconhecimento do grau de socialização dos bens e serviços sociais que seria tolerável nas sociedades capitalistas. Trata-se do questionamento das fontes de sustentação do Welfare State, isto é, do modelo de desenvolvimento e do sistema de relações sociais que ele representa, principalmente quanto à coesão social e à solidariedade. O conceito do Welfare State se constituiu com base no indivíduo e não estimulava as relações interpessoais e a solidariedade. O autor critica também, nesse sentido, o modelo de Estado social-democrata, pois a forma como foi construído leva a enxergar o social sempre como encargo do Estado e, quando este deixa de dar conta dele, os indivíduos dessocializados ficam destituídos de qualquer amparo e referência; em suma, no isolamento.

Srour (2005, p. 61-83) corrobora, mas acredita em possibilidade de evolução na qualidade de vida da sociedade. No final do século XX, o "capitalismo excludente", caracterizado pelo autor por prevalência de maximização dos lucros à custa de má remuneração dos empregados, 
uso do poder de barganha das grandes corporações contra pequenos fornecedores e estímulo do consumo nas populações de baixa renda, transfigura-se em "capitalismo social", caracterizado pela dupla lógica, do lucro e da responsabilidade social.

\begin{abstract}
Mas as presenças significativas dos ideários do neoliberalismo e do darwinismo social, ambas correntes ideológicas bem representadas pela ala tradicionalista ou ultraconservadora dos republicanos nos Estados Unidos, assinalam que o acirramento da competição pode levar ao egoísmo e à falta de solidariedade social. Há claras tendências, porém, que apontam para a melhoria da qualidade de vida oferecida aos habitantes das sociedades avançadas. (SROUR, 2005, p. 71).
\end{abstract}

Para Freitas (2000, p. 10), a sociedade presencia um "movimento de revalorização do papel das empresas" e um dos fatores é a "crise de identidade vivida pelos indivíduos". A quebra das referências culturais e religiosas tradicionais tornou os indivíduos vulneráveis a líderes que mostrem um caminho com "um pouco mais de certeza". As organizações modernas encontram espaço para se posicionar como referencial que propõe uma "forma de vida de sucesso e uma missão nobre a realizar".

Esse movimento se deve, em grande medida, à 'confirmação' do capitalismo como a 'única' via capaz de promover o desenvolvimento econômico e a crescente legitimação da ideologia neoliberal, em que o econômico assume o papel predominante e subordina todas as demais esferas da vida social. A crise nas instituições tradicionais da sociedade fomenta essa primazia do econômico. É verdade que toda a sociedade deve ser capaz de desenvolver as condições de sua sobrevivência material, mas é neste momento histórico específico que podemos verificar uma tendência reducionista que atribui ao aspecto econômico a importância de todas as coisas. A própria política se transforma numa simples gestora de índices econômicos. [...] O Estado - falido e desacreditado - deve se restringir a oferecer as condições necessárias de infra-estrutura e deixar que as empresas se ocupem do que garante o emprego, a competitividade dos mercados e a potência da nação neste mundo globalizado. Investidas como o novo pólo da legitimação social e como o lugar que pode responder pelo esfacelamento dos vínculos sociais e pelas questões identitárias, as organizações modernas - com ênfase nas grandes empresas - constroem para e de si uma auto-imagem grandiosa, que vai enraizar-se num imaginário próprio, que é repassado não apenas para os seus membros internos mas também para a sociedade no seu conjunto. (FREITAS 2000, p. 10).

Passador e Ferraz (2007) defendem a descentralização do Estado e colocam a necessidade de inovar as políticas públicas de melhoria social, promovendo o desenvolvimento local com participação da comunidade - sociedade civil e mercado.

As políticas, principalmente da última década, de liberalizar, privatizar, flexibilizar as relações de trabalho e diminuir cada vez mais a presença do Estado na sociedade acabaram por impor uma revisão urgente da teoria e da prática do desenvolvimento econômico. [...] Nessa linha, passa-se a pensar na idéia de desenvolvimento local, ou seja, na regionalização das políticas sociais sendo que, a função do Estado não é mais a de resolver os problemas da população, mas estimular e incentivar as comunidades a se mobilizarem para que elas desenvolvam suas potencialidades e vocações e a partir daí, resolvam os seus problemas. (PASSADOR e FERRAZ, 2007, p. 9). 
Portanto, a sociedade norteada pelo conceito do Estado Mínimo não só abre espaço para a responsabilidade social empresarial como a estimula por meio de incentivos fiscais. Por exemplo, as empresas podem direcionar parte do imposto de renda para projetos de apoio ao esporte, apoio à cultura, apoio aos direitos da criança e do adolescente, entre outros. Com isso, as empresas, por meio de investimentos sociais, ocupam um espaço "deixado" pelo Estado. Resta saber se tais investimentos podem ser considerados distribuição de renda. Para tanto, é importante avaliar as teorias que buscam explicar esse comportamento das empresas.

\subsection{Responsabilidade Social Corporativa}

Responsabilidade Social Corporativa é um tema discutido na academia nacional e internacional. Diversos artigos fizeram uma revisão crítica da literatura, considerando a diversidade de definições e teorias acerca do tema (entre eles: Frederick, 1998; Carroll, 1999; Garriga e Melé, 2004; Ashley, Coutinho e Tomei, 2000; Passador e Ferraz, 2007). Essa diversidade dificulta o desenvolvimento de uma sequência lógica sobre o tema. Assim, neste trabalho optou-se por adotar a classificação proposta por Garriga e Melé (2004) para organizar o desenvolvimento do referencial teórico sobre o assunto.

Não existe ainda um consenso sobre a definição de responsabilidade social. Em um extremo, há uma visão mais econômica em que a empresa é socialmente responsável se maximizar os ganhos do acionista de maneira ética, pois assim estará beneficiando a economia e a sociedade. Em outro extremo, há quem defenda que a responsabilidade social abrange ações de filantropia da empresa, ainda que estas não estejam relacionadas com suas atividades operacionais. Entre esses extremos, há uma série de definições. E, ainda, há quem defenda que a responsabilidade social é um continuum entre esses dois extremos, isto é, a empresa parte de uma visão focada no acionista e evolui para uma visão focada nos stakeholders.

Assim como a teoria de Responsabilidade Social Corporativa (RSC), que ainda é muito diversificada e muitas vezes divergente, a prática social nas empresas varia de ações simples passíveis de propaganda que geram poucas mudanças reais na sociedade até investimentos sociais reais que intervêm significativamente na comunidade local. 
Quadro 2 - Teorias de Responsabilidade Social Corporativa e abordagens relacionadas

\begin{tabular}{|c|c|c|c|}
\hline Tipos de teorias & Abordagens & Breve descrição & Algumas Referências-chave \\
\hline \multirow{5}{*}{$\begin{array}{l}\text { Teorias } \\
\text { Instrumentais } \\
\text { (foco no alcance } \\
\text { de objetivos } \\
\text { econômicos por } \\
\text { meio de } \\
\text { atividades } \\
\text { sociais) }\end{array}$} & $\begin{array}{l}\text { Maximização do } \\
\text { valor do acionista }\end{array}$ & $\begin{array}{l}\text { Maximização de valor em longo } \\
\text { prazo }\end{array}$ & $\begin{array}{l}\text { Friedman (1970), Jensen } \\
(2000)\end{array}$ \\
\hline & \multirow{3}{*}{$\begin{array}{l}\text { Estratégias para } \\
\text { obtenção de } \\
\text { vantagem } \\
\text { competitiva }\end{array}$} & $\begin{array}{l}\text { Investimentos sociais em um } \\
\text { contexto competitivo }\end{array}$ & Porter e Kramer (2002) \\
\hline & & $\begin{array}{l}\text { Estratégias baseadas na visão de } \\
\text { recursos naturais da empresa e } \\
\text { capacidades dinâmicas da } \\
\text { empresa }\end{array}$ & Hart (1995), Litz (1996) \\
\hline & & $\begin{array}{l}\text { Estratégias para a base da } \\
\text { pirâmide econômica }\end{array}$ & $\begin{array}{l}\text { Prahalad e Hammond } \\
\text { (2002), Hart e Christensen } \\
\text { (2002), Prahalad (2003) }\end{array}$ \\
\hline & $\begin{array}{l}\text { Estratégia de } \\
\text { marketing }\end{array}$ & $\begin{array}{l}\text { Atividades altruístas socialmente } \\
\text { reconhecidas usadas como um } \\
\text { instrumento de marketing }\end{array}$ & $\begin{array}{l}\text { Varadarajan e Menon } \\
\text { (1988), Murray e Montanari } \\
(1986)\end{array}$ \\
\hline \multirow{3}{*}{$\begin{array}{l}\text { Teorias } \\
\text { Políticas } \\
\text { (foco no uso } \\
\text { responsável do } \\
\text { poder do } \\
\text { negócio na } \\
\text { arena política) }\end{array}$} & $\begin{array}{l}\text { Constitucionalismo } \\
\text { corporativo }\end{array}$ & $\begin{array}{l}\text { Responsabilidade social do } \\
\text { negócio resulta da quantidade de } \\
\text { poder social que ele tem }\end{array}$ & Davis $(1960,1967)$ \\
\hline & $\begin{array}{l}\text { Teoria do Contrato } \\
\text { Social Integrativo }\end{array}$ & $\begin{array}{l}\text { Assume a existência do contrato } \\
\text { social entre a empresa e a } \\
\text { sociedade }\end{array}$ & $\begin{array}{l}\text { Donaldson e Dunfee (1994, } \\
\text { 1999) }\end{array}$ \\
\hline & $\begin{array}{l}\text { Cidadania } \\
\text { corporativa (ou } \\
\text { empresarial) }\end{array}$ & $\begin{array}{l}\text { A firma é vista como um } \\
\text { cidadão com certo envolvimento } \\
\text { na comunidade }\end{array}$ & $\begin{array}{l}\text { Wood e Logson (2002), } \\
\text { Andriof e McIntoch (2001), } \\
\text { Matten e Crane (no prelo) }\end{array}$ \\
\hline \multirow{4}{*}{$\begin{array}{l}\text { Teorias } \\
\text { Integrativas } \\
\text { (foco na } \\
\text { integração das } \\
\text { demandas } \\
\text { sociais) }\end{array}$} & $\begin{array}{l}\text { Administração de } \\
\text { demandas }\end{array}$ & $\begin{array}{l}\text { Processo corporativo de resposta } \\
\text { àquelas questões sociais e } \\
\text { políticas que podem impactar } \\
\text { significativamente o negócio }\end{array}$ & $\begin{array}{l}\text { Sethi (1975), Ackerman } \\
\text { (1973), Jones (1980), Vogel } \\
\text { (1986), Wartick e Mahon } \\
\text { (1994) }\end{array}$ \\
\hline & $\begin{array}{l}\text { Responsabilidade } \\
\text { pública }\end{array}$ & $\begin{array}{l}\text { A lei e as políticas públicas } \\
\text { existentes são tomadas como } \\
\text { referência para o desempenho } \\
\text { social }\end{array}$ & Preston e Post $(1975,1981)$ \\
\hline & $\begin{array}{l}\text { Gestão de } \\
\text { stakeholders }\end{array}$ & $\begin{array}{l}\text { Equilibra os interesses dos } \\
\text { stakeholders da firma }\end{array}$ & $\begin{array}{l}\text { Mitchell et al. (1997), Agle } \\
\text { e Mitchell (1999), Rowley } \\
\text { (1997) }\end{array}$ \\
\hline & $\begin{array}{l}\text { Desempenho social } \\
\text { corporativo }\end{array}$ & $\begin{array}{l}\text { Busca a legitimidade social e } \\
\text { processos para dar respostas } \\
\text { apropriadas às questões sociais }\end{array}$ & $\begin{array}{l}\text { Carroll (1979), Wartick e } \\
\text { Cochran (1985), Wood } \\
\text { (1991b), Swanson (1995) }\end{array}$ \\
\hline \multirow[t]{4}{*}{$\begin{array}{l}\text { Teorias Éticas } \\
\text { (foco na coisa } \\
\text { certa para } \\
\text { alcançar uma } \\
\text { boa sociedade) }\end{array}$} & $\begin{array}{l}\text { Teoria normativa } \\
\text { dos stakeholders }\end{array}$ & $\begin{array}{l}\text { Considera as obrigações } \\
\text { fiduciárias da firma com os } \\
\text { stakeholders. Sua aplicação } \\
\text { requer referência a teorias } \\
\text { morais (kantiano, utilitarismo, } \\
\text { teorias de justiça, etc.) }\end{array}$ & $\begin{array}{l}\text { Freeman (1984, 1994), Evan } \\
\text { e Freeman (1988), } \\
\text { Donaldson e Preston (1995), } \\
\text { Freeman e Phillips (2002), } \\
\text { Phillips et al. (2003) }\end{array}$ \\
\hline & Direitos universais & $\begin{array}{l}\text { Estrutura baseada em direitos } \\
\text { humanos, direito do trabalhador } \\
\text { e respeito ao meio ambiente }\end{array}$ & $\begin{array}{l}\text { The Global Sullivan } \\
\text { Principles (1999), UN } \\
\text { Global Compact (1999) }\end{array}$ \\
\hline & $\begin{array}{l}\text { Desenvolvimento } \\
\text { sustentável }\end{array}$ & $\begin{array}{l}\text { Visa a atingir o desenvolvimento } \\
\text { humano considerando as } \\
\text { gerações presentes e futuras }\end{array}$ & $\begin{array}{l}\text { World Commission on } \\
\text { Environment and } \\
\text { Development (Brutland } \\
\text { Report) (1987), Gladwin e } \\
\text { Kennelly (1995) }\end{array}$ \\
\hline & O bem comum & $\begin{array}{l}\text { Orientada para o bem comum da } \\
\text { sociedade }\end{array}$ & $\begin{array}{l}\text { Alford e Naughton (2002), } \\
\text { Mele (2002), Kaku (1997) }\end{array}$ \\
\hline
\end{tabular}

FONTE: GARRIGA; MELÉ, 2004, p. 63-64, tradução livre (Anexo B traz o quadro original e todas as referências citadas pelos autores). 
Garriga e Melé (2004) classificaram as teorias de RSC conforme o resumo exposto no Quadro 2. Os autores trouxeram uma separação conforme o tratamento dado à relação empresasociedade. São dois níveis de classificação, o primeiro classifica a teoria, e o segundo agrupa as diferentes abordagens encontradas para a mesma teoria.

É interessante notar que muitas abordagens (expostas no Quadro 2) não mostram uma concentração em determinado período no tempo. Diferentes teorias convivem em um mesmo período. Percebe-se que as visões dos textos que abordam teorias de RSC estão relacionadas com a formação do pesquisador, nota-se grande diferença entre os trabalhos de economistas e os trabalhos de sociólogos, e, aparentemente, as diferentes visões também estão ligadas aos valores pessoais (tendências políticas e valores éticos, principalmente). Talvez por isso, exista tamanha diversidade de teorias que tentam explicar a RSC. O texto de Gray, Kouhy e Lavers (1995a) é um exemplo a citar (o mais extremo talvez). Os autores criticam com veemência a teoria positiva da contabilidade, afirmando ser altamente ofensiva (p. 52, tradução livre) a suposição central dos indivíduos serem movidos apenas por autointeresse ${ }^{4}$, e, fica evidente, não pelo texto mas também pela nota que os autores colocam, que sua crítica está mais relacionada aos seus valores ${ }^{5}$.

Com os grupos teóricos de Garriga e Melé (2004) como norteadores, este tópico foi subdividido em quatro partes e serão analisados os textos sugeridos pelo autor e outros de interesse para o trabalho.

\subsubsection{Teorias Instrumentais}

O primeiro grupo teórico definido por Garriga e Melé (2004, p. 52), chamado "teorias instrumentais", assume que a empresa é um instrumento para criação de riqueza para o acionista e essa é sua única responsabilidade social. Considera-se apenas o aspecto econômico das interações entre o negócio e a sociedade. Por isso, nenhuma ação social é realizada se não

\footnotetext{
${ }^{4}$ In addition, its central assumption that all actions are motivated by a morally degenerate form of short-term self-interest [...] seems not only empirically implausible but also highly offensive. (GRAY; KOUHY; LAVERS, 1995, p. 51-52).

${ }^{5}$ It is therefore difficult to address sensibly something which one believes to be virtual rubbish. Indeed the Messianic glint with which economic agency theory and positive accounting theory are proselytized is seriously reminiscent of the Inquisition. We much prefer our position as "heretics". (GRAY; KOUHY; LAVERS, 1995, p. 70 , notas de fim de texto).
} 
houver impacto positivo na criação de riqueza para os investidores. Os autores justificam o nome atribuído dizendo que a RSC para estas teorias é apenas um instrumento para o objetivo maior de gerar riqueza para o acionista. Este grupo de teorias está dividido em três abordagens: (i) maximização do valor do acionista, (ii) estratégia para obtenção de vantagem competitiva e (iii) estratégia de marketing.

A primeira abordagem se caracteriza, geralmente, por uma visão de curto prazo e tem como referência os preços das ações das empresas. O critério adotado para a tomada de decisão é a contribuição direta para a riqueza do acionista. Portanto, se o investimento social apenas impõe um custo à companhia, ele será rejeitado (GARRIGA; MELÉ, 2004, p. 53-54).

O protagonista das teorias instrumentais, com a abordagem de maximização do valor do acionista, é Friedman (1970) com a afirmação de que a responsabilidade social do negócio é aumentar seus lucros. Conforme citado anteriormente, o autor, quase sempre referenciado nos textos sobre o assunto, defende que a única responsabilidade social da empresa é usar os recursos de modo a aumentar seus lucros, contribuindo para uma competição aberta e livre, sem enganações ou fraudes. Esse autor separa o comportamento dos proprietários de pequenas empresas dos executivos de grandes empresas e refere-se principalmente aos últimos. Em sua visão, a empresa não é uma pessoa, por isso não tem responsabilidades, os indivíduos é que as têm. Nesse contexto, o papel do executivo, enquanto agente, isto é, agindo em nome de outros, inclui apenas atingir os objetivos de seus empregadores. E, para as empresas com fins lucrativos, esse objetivo é ter lucros. Assim, o executivo não pode aumentar as despesas da empresa realizando investimentos sociais se isso não for gerar lucro para os acionistas. A teoria de Friedman tem muitos adeptos e muitos desafetos.

\footnotetext{
Há poucas coisas capazes de minar tão profundamente as bases de nossa sociedade livre como a aceitação por parte dos dirigentes das empresas de uma responsabilidade social que não a de fazer tanto dinheiro quanto possível para seus acionistas. Trata-se de uma doutrina fundamentalmente subversiva. Se os homens de negócios têm outra responsabilidade social que não a de obter o máximo de lucro para seus acionistas, como poderão eles saber qual seria ela? Podem decidir sobre que carga impor a si próprios e a seus acionistas para servir ao interesse social? (FRIEDMAN, 1988, p. 120).
}

A posição de Friedman sobre RSC é caracterizada como fundamentalista e foi deduzida da chamada visão de "reconhecimento legal" que defende a empresa como uma entidade autônoma, não criada pela sociedade, mas formada e administrada por um grupo constituído livremente, portanto sem obrigações morais e sociais especiais. Entretanto, a empresa é uma 
instituição social e não apenas uma instituição econômica. Considerando a natureza social do negócio, as corporações, seus proprietários, administradores e diretores deveriam "abandonar a visão incompleta e arcaica da corporação ser uma instituição limitadamente econômica". (KLONOSKI, 1991, p. 17).

\begin{abstract}
A ideologia da responsabilidade social empresarial tem sua origem em uma geopolítica mundial em tensão por uma disputa ideológica envolvendo o liberalismo, particularmente a escola neoliberal, e o crescente movimento pela intervenção do Estado na economia, por meio da concepção do Estado de bem-estar social, materializado pela social-democracia européia. Esse debate socioeconômico no período de reconstrução da economia capitalista no contexto da guerra fria, pós-Segunda Guerra Mundial, está presente nos postulados de H. Bowen (1953), ao afirmar a doutrina da responsabilidade social como uma alternativa possível para se evitar um maior controle da economia pelo Estado. Em meio ao conflito entre a teoria neoliberal e a concepção da responsabilidade social corporativa, vale destacar as manifestações que indicam a preocupação em torno da ética nos negócios como necessária para a própria sobrevivência das organizações, devido às relações de poder que envolvem as organizações e os diversos influenciadores externos. Conseqüentemente, a ideologia da responsabilidade social demonstra a preocupação das organizações com a pressão dos influenciadores externos nas relações sociais de poder, resultado de mudanças sociais que impulsionaram a aceitação de novas normas, que, por sua vez, tornaram comportamentos anteriores socialmente inaceitáveis. Na realidade, o discurso da ideologia liberal, do negócio estritamente associado ao lucro, tornou-se contraproducente para as exigências de diferenciação na economia capitalista competitiva. (BITTENCOURT E CARRIERI, 2005, p. 20).
\end{abstract}

Gray, Kouhy e Lavers (1995a), como já demonstrado, estão entre os desafetos da teoria econômica da responsabilidade social. Vale acrescentar que os autores não fazem referência direta a Friedman nesse texto, mas criticam trabalhos empíricos que estudam a relação investimento social/lucro, baseados na perspectiva da teoria positiva da contabilidade que, por sua vez, é calcada nas mesmas teorias econômicas defendidas por Friedman.

Segundo Gray, Kouhy e Lavers (1995a, p. 51), além das questões intelectuais que devem ser levantadas ao estudar essa abordagem, duas contradições se destacam ao usar a teoria positiva da contabilidade para explicar a responsabilidade social empresarial, ambas relacionadas aos pressupostos das teorias. A primeira diz respeito ao uso por esses trabalhos empíricos da hipótese de mercado eficiente (preços de mercado em equilíbrio, não há assimetria informacional, nem diferentes aversões ao risco, nem variação na capacidade de interpretação e precificação da informação), ao passo que a teoria de RSC é motivada primordialmente pelas falhas do mercado. A segunda contrapõe o pressuposto da teoria positiva de não dizer como a realidade "deveria ser", mas sempre observar como ela é e tentar explicá-la, com a ideia da RSC de mudar as práticas atuais do mercado e da sociedade. Assim, na visão desses autores, a teoria econômica não pode ser usada para explicar a RSC. 
Jensen (2000) defende que, em um mercado sem externalidades nem monopólio, a maximização de lucros para os acionistas implica em contribuir para o bem-estar da sociedade, pois haverá geração de empregos, pagamentos de impostos e movimentação da economia. Todavia, o autor reconhece a dificuldade de se criar valor para os acionistas sem haver uma boa relação com consumidores, empregados, credores, fornecedores, comunidade local, enfim, stakeholders. E reconhece ainda o conflito de interesses entre esses grupos, por isso, sugere usar a maximização do valor da empresa em longo prazo para decidir nessas situações de conflitos. O autor ressalta a importância de o governo combater o monopólio e as externalidades, pois as empresas não evitarão esses malefícios voluntariamente, e, nessas condições, toda a sociedade perde.

McWilliams e Siegel (2001) investigam a existência de um nível adequado de investimento em RSC, dado o objetivo de maximizar os lucros em longo prazo. Baseados na teoria de oferta e demanda, os autores desenvolvem um modelo de análise da relação custo-benefício do investimento social e concluem que "geralmente, haverá uma relação neutra entre ações de RSC e o desempenho financeiro da firma” (p. 125). Percebe-se uma análise extremamente racional, coerente com essa abordagem teórica de RSC.

Alguns trabalhos já tentaram encontrar uma relação entre investimentos sociais e retorno econômico das empresas no Brasil. Bertagnolli, Ott e Damacena (2006) estudaram o nível de influência dos investimentos sociais e ambientais no desempenho econômico das empresas e concluíram que tanto a receita líquida como o resultado operacional das empresas pesquisadas estão associados aos investimentos sociais e ambientais realizados, com destaque para os benefícios direcionados aos funcionários. Borba (2005) criou uma métrica de avaliação do desempenho social e a relacionou com desempenho financeiro. Os resultados do autor não rejeitaram a hipótese de ausência de relação entre as variáveis. Kitahara (2007) não rejeitou a hipótese de relação entre investimentos sociais e desempenho financeiro, apesar de não apresentar amostra significativa, mas não conseguiu identificar um modelo que explicasse a racionalidade da decisão de investimento social.

A segunda abordagem das teorias instrumentais é focada em estratégias para buscar vantagens competitivas que poderiam aumentar os lucros em longo prazo. Três tipos de estratégias podem ser definidos: (i) investimentos sociais para melhorar o contexto competitivo, (ii) investimentos socioambientais para aumentar a sinergia entre recursos humanos, naturais e 
físicos e (iii) desenvolvimento de produtos voltados para a base da pirâmide social em busca de transformá-la em consumidores ativos (GARRIGA; MELÉ, 2004, p. 54).

O contexto competitivo depende das condições dos fatores de produção, da demanda local, do ambiente político e dos demais elos da cadeia produtiva. Os fatores de produção envolvem mão de obra qualificada, recursos naturais disponíveis, tecnologia disponível e infraestrutura adequada. Por demanda local entende-se a qualidade e o tamanho do mercado local e ainda, como a empresa pode influenciar essas variáveis. $\mathrm{O}$ ambiente político engloba desde abertura de mercado, incentivos e regras de atuação no mercado até combate à corrupção e práticas ilegais, como formação de cartéis. Por fim, o contexto competitivo depende de seus fornecedores de insumos, dos fornecedores de bens de capital, de prestadores de serviço, de revendedores etc. A empresa depende do contexto competitivo, portanto os investimentos sociais relacionados a esse contexto podem representar importante melhoria em cada uma de suas vertentes e, consequentemente, geram vantagem competitiva para o negócio (PORTER; KRAMER, 2002).

\begin{abstract}
É verdade que há muito tempo objetivos econômicos e sociais são vistos como distintos e muitas vezes concorrendo entre si. Mas é uma falsa dicotomia, que representa uma perspectiva obsoleta num mundo de competição aberta e fundada no conhecimento. A empresa não opera isolada da sociedade que a cerca. A rigor, a capacidade de competir depende muito das circunstâncias dos locais onde opera. A melhoria do ensino, por exemplo, é em geral vista como questão social, mas o nível educacional da força de trabalho local afeta significativamente o potencial competitivo da empresa. Quanto mais relacionada estiver a melhoria social com a área de atuação da empresa, mais ela irá gerar benefícios econômicos. (PORTER; KRAMER, 2002, p. 45).
\end{abstract}

A produtividade da empresa depende da sinergia entre os fatores de produção, quais sejam: recursos humanos, naturais e físicos. O desenvolvimento de novos recursos e novas capacidades depende das restrições e desafios do meio ambiente. Por isso, Hart (1995) propõe três estratégias integradas para obter vantagem competitiva: prevenção da poluição, gestão do produto e desenvolvimento sustentável.

Países em desenvolvimento, como China, Índia e Brasil, têm um grande mercado consumidor potencial nas populações mais pobres. O investimento no desenvolvimento de produtos diferenciados para esse público, produtos de baixo custo e serviços essenciais, é uma maneira de aumentar os lucros da empresa, mas também de gerar desenvolvimento econômico local. 
A última abordagem das teorias instrumentais traz o uso de atitudes socioambientalmente responsáveis para promoção da empresa ou de uma marca da empresa. É o caso dos selos colocados em produtos, como o selo "empresa amiga da criança" promovido pela Fundação Abrinq pelos Direitos da Criança e do Adolescente, e de promoções de eventos esportivos ou culturais que beneficiem uma causa social. Também é o caso de promoções em que o faturamento de determinado dia ou determinado produto é doado para entidades filantrópicas, como é o caso do McDia Feliz, promovido pela rede McDonald's, um dos precursores desta estratégia.

Para Schommer (2000, p. 148), o entendimento de responsabilidade social se relaciona diretamente com as ações voltadas para o lucro. Pode até mesmo incluir ações filantrópicas ou outras mais substanciais para a comunidade, desde que também haja retorno para a empresa. Nesse sentido, o conceito de responsabilidade social implicaria em duas lógicas que convivem no espaço organizacional. Em uma estaria um modelo de gestão que apregoa a ênfase na abertura à responsabilidade e à ética, em outra surge a filantropia de alto rendimento, com foco no marketing, nas exigências do mercado, e em restrições e benefícios legais oriundos do governo.

Varadarajan e Menon (1988) definem essa abordagem (cause-related marketing - CRM) como um "programa de marketing que busca atingir dois objetivos - melhorar o desempenho corporativo e ajudar causas dignas - por meio da vinculação entre a arrecadação de fundos para benefício da causa e a compra de produtos ou serviços da empresa." ${ }^{6}$ (p. 59, tradução livre). E também destacam a diferença de CRM e de promoção de vendas, filantropia corporativa, patrocínio corporativo, relações públicas e ações corporativas como "boa samaritana”. O texto ressalta diversas vezes que CRM é uma estratégia para vender, não para fazer contribuições com caridade. Os gastos com divulgação do programa são, normalmente, bem maiores que os valores recebidos pela causa beneficiada. Por fim, os autores alertam para a necessidade de uma promoção clara do programa, para que as empresas não sejam taxadas de "exploradoras" da causa social.

Nesse cenário, são muitas as críticas que pululam em torno do desvirtuamento da questão social assumida pelas organizações governamentais e fundações sociais no país. De um lado, o que se

\footnotetext{
${ }^{6}$ It is basically a marketing program that strives to achieve two objectives - improve corporate performance and help worthy causes - by linking fund raising for the benefit of a cause to the purchase of the firm's products and/or services. (VARADARAJAN; MENON, 1988, p. 59).
} 
alega é que essa ênfase que o privado tem dado às questões sociais tem provocado um deslocamento da política e da noção de cidadania, passando do âmbito de uma conquista e de um direito social, para o campo do favor e da filantropia. De outro, a crítica se foca na troca mercantil presente nessas ações sociais empresariais, a partir das quais as empresas buscam, na verdade, agregar valor às suas marcas. A viabilidade e lisura dessa troca são explicitadas nas palavras do consultor brasileiro - e também um grande idealizador do papel do empresariado nas questões sociais - Stephen Kanitz, ao demonstrar os ganhos que a empresa teria exercendo a "filantropia estratégica". [...] Nesse aspecto, a crítica a tal "filantropia estratégica" se divide entre a mais radical, que aponta para um uso mercadológico da miséria; e uma crítica mais pontual, voltada para as empresas que pervertem essa prática ao lançarem mão do discurso da responsabilidade social, sem exercê-la de fato, tendo em vista tão somente a busca da ampliação do valor de sua marca. (FONTANELLE, 2006, p. 2).

Essa abordagem pode realmente ser bastante arriscada, pois pode haver distorção da verdadeira intenção da empresa. Por mais transparente que a empresa seja, a sociedade, sem formação na área de negócios, não percebe a estratégia adotada como uma simples estratégia de marketing. Uma pesquisa brasileira mostrou que $42 \%$ da sociedade acredita que a missão da empresa é desenvolver trabalhos comunitários, enquanto apenas $10 \%$ dizem que a missão da empresa é gerar lucro para os acionistas (EXAME, 2005, p.21).

$\mathrm{Na}$ visão empresarial, essas são estratégias ganha-ganha, ou seja, a empresa ganha e a causa social também. De fato são. A causa não teria o benefício se não fosse pela iniciativa da empresa. Também é fato que a estratégia pode ser usada com má fé. Mas cabe à sociedade fiscalizar a transferência do benefício para a causa social. É importante que a sociedade se envolva com esses projetos, pois é a melhor maneira de evitar que as empresas mal intencionadas conquistem esse espaço.

Enfim, a "consciência" das empresas limita-se ao que lhes garante que permaneçam no jogo e que o ganhem. Estarão elas erradas? Não, ganhar o jogo é a sua missão e a sua natureza [...]. No discurso de cidadania das grandes empresas, duas frentes têm sido privilegiadas: apoio à cultura e à ecologia. No caso de apoio a projetos culturais, nunca se menciona o retorno que tais projetos podem proporcionar, seja em imagem institucional, seja em dividendos políticos, seja em redução de custos de campanhas publicitárias. Ora, cada vez mais a publicidade convencional apresenta limites de eficácia; atualmente, busca-se uma valorização da empresa como um todo, e não de um produto específico. Cada vez mais os produtos são efêmeros, mas uma marca consolidada é sempre uma marca garantida, não importando que produto ela decide vestir. A indústria cultural é um verdadeiro setor econômico, e as ações empresariais não devem ser confundidas com caridade, altruísmo ou mecenato. Mais uma vez, não estamos dizendo que as empresas estão erradas em enveredar por esse caminho, mas estamos, sim, marcando o que se trata de um discurso que procura, conscientemente, induzir ao equívoco. A questão ecológica levanta entusiasmos e enganos semelhantes. Por um lado, não é favor a nenhum país preservar o que pertence ao planeta de todos. Por outro, cada vez mais é verdade que, para se exportar para alguns mercados, é necessário obedecer a alguns critérios que consideram a redução de danos ecológicos, como a utilização de matérias-primas não-tóxicas e que não estejam em risco de extinção, a produção de embalagens que sejam recicláveis, a não-utilização de seres humanos como cobaias, a preservação da flora e da fauna dos ecossistemas ameaçados, o fato de não comprar a miséria de crianças e do trabalho escravo, etc. [...] Respeitar a ecologia, se não dá dinheiro, pode evitar muito prejuízo. (FREITAS, 2000, p. 11). 
O grupo de teorias instrumentais mostra que a empresa decide realizar investimentos sociais com base em racionalidade econômica. Ou seja, de acordo com as teorias desse grupo, as empresas fazem contas, fazem pesquisas, fazem previsões e, somente quando o impacto econômico é positivo para elas, elas realizam os investimentos. Não há envolvimento de questões morais ou éticas, exceto quando isso implica em prejuízo para a imagem da empresa.

\subsubsection{Teorias Políticas}

O segundo grupo teórico definido por Garriga e Mele (2004, p. 52), intitulado "teorias políticas”, enfatiza o poder da organização no contexto em que está inserida, especificamente na relação empresa-sociedade. Discute-se a arena política associada ao poder da empresa na sociedade, o que leva a empresa a aceitar seus direitos e deveres sociais ou participar por meio de alguma cooperação social. Esse grupo também apresenta três abordagens: (i) poder exercido pela empresa na sociedade, (ii) teoria do contrato social implícito entre empresa e sociedade e (iii) o conceito de cidadania corporativa.

Davis (1960) afirma que a responsabilidade social tem duas faces. Na primeira, o administrador reconhece sua intervenção em uma unidade social e, por consequência, sua obrigação com essa comunidade devido à possibilidade do bem-estar público ser afetado pelo desenvolvimento econômico. A segunda diz respeito à obrigação do administrador com a educação e desenvolvimento dos valores humanos (como cooperação, motivação e realização no trabalho). Essas responsabilidades da empresa devem ser consideradas em qualquer decisão tomada pelo administrador, apesar, é óbvio, de não serem os únicos fatores a se considerar. Vale ressaltar que as decisões são tomadas pelos administradores e não pelo negócio em si, este último pode oferecer apenas estrutura cultural, direcionamento político e objetivos a serem alcançados. Esse poder da decisão do administrador na empresa é transferido para a sociedade porque as decisões a afetam diretamente, surgindo o poder social da empresa.

\footnotetext{
À extensão que os administradores ou qualquer outro grupo tenha poder social, as lições da história sugerem que sua responsabilidade social deveria se igualar. De modo geral, pode-se dizer que a responsabilidade social dos administradores deve ser proporcional ao seu poder social. [..] A idéia de igualdade entre poder e responsabilidade não é estranha aos administradores. Por exemplo, um dos princípios da teoria da administração é que autoridade e responsabilidade devem ser balanceadas de modo que cada empregado e cada administrador seja responsável à extensão de
} 
sua autoridade e vice-versa. Apesar desse princípio se referir aos relacionamentos internos da empresa, parece que também se aplicaria bem a toda a sociedade externa à firma. ${ }^{7}$ (DAVIS, 1960, p. 71-72, tradução livre).

Levitt (1958, p. 44) alerta para a possibilidade de se voltar ao feudalismo, se toda a autoridade dos administradores tiver proporcional responsabilidade social atribuída a eles. Se a firma assumir a responsabilidade pelo bem-estar de todos os seus empregados, volta-se a ter o paternalismo e a autocracia existente na época.

Selekman (1959, p. 23) prevê uma catástrofe se a empresa se desviar completamente de seu objetivo principal, fornecer produtos e serviços para a sociedade, em prol de atender a tantas responsabilidades a ela atribuídas. Para evitar isso, sugere uma forma de constitucionalismo, no qual a responsabilidade do negócio, além de seus objetivos econômicos, é administrar seus assuntos em conformidade com uma estrutura constitucional estabelecida mutuamente por todos os stakeholders. Com isso, Davis (1960) alerta: menor responsabilidade, menor poder. E outros grupos devem aparecer para assumir esse poder no lugar das empresas. Entretanto, estas não deverão conceder esse poder facilmente.

O tema responsabilidade social coloca o campo dos negócios em uma importante encruzilhada de sua história. Qual caminho será escolhido não se sabe, mas em qualquer opção a responsabilidade social tenderá a ser igual ao poder social, o que significa que evitar responsabilidades conforme elas aparecem, levará à perda de poder. [...] Claramente, as funções econômicas do negócio são primordiais, mas isso não nega a existência de funções e responsabilidades não-econômicas. $\mathrm{O}$ preço da liberdade social é seu exercício responsável. Como a sociedade está mudando, as evidências sugerem que a continuidade do vigor nos negócios depende da franca aceitação das responsabilidades sócio-humanas. [...] Em resumo, a primeira responsabilidade social do negócio é encontrar soluções viáveis considerando a natureza e extensão de suas próprias responsabilidades sociais. ${ }^{8}$ (DAVIS, 1960, p. 75-76, tradução livre).

\footnotetext{
${ }^{7}$ To the extent that businessmen or any other group have social power, the lessons of history suggest that their social responsibility should be equated with it. Stated in the form of a general relationship, it can be said that social responsibilities of businessmen need to be commensurate with their social power. [...] The idea of coequal power and responsibility is no stranger to business either. For example, one of the tenets of scientific management is that authority and responsibility should be balanced in such a way that each employee and manager is made responsible to the extent of his authority and vice versa. Although this tenet refers to relationships within the firm, it seems that it would apply as well to the larger society outside the firm. (DAVIS, 1960, p. 71-72).

${ }^{8}$ The subject of social responsibility places business at an important crossroads in its history. Which way it will go is not known, but in any event social responsibility will tend to equate with social power, which means that avoidance of responsibilities as they develop will lead to loss of business power. [...] Clearly, economic functions of business are primary, but this does not negate the existence of non-economic functions and responsibilities. The price of social freedom is its responsible exercise. Because society is changing, evidence suggests that the continued vigor of business depends upon its forthright acceptance of further socio-human responsibilities. [...] In summary, the first social responsibility of business is to find workable solutions regarding the nature and the extent of their own social responsibilities. (DAVIS, 1960, p. 75-76).
} 
Davis (1967) afirma que a essência da responsabilidade social está no reconhecimento pelos administradores de que o negócio não existe sozinho e que um "negócio saudável" não sobrevive em uma "sociedade doente" (p.46). Várias razões fizeram o tema responsabilidade social ficar em evidência: (i) o pluralismo da sociedade moderna aumenta o interesse por responsabilidade social porque multiplica os centros de poder social e cada um deve assumir sua responsabilidade proporcional; (ii) a complexidade da sociedade e a maior dependência das partes entre si aumentam o interesse de ver as necessidades dos parceiros atendidas; (iii) uma intervenção do governo nesse sentido não seria benéfica para os negócios e tais intervenções costumam perdurar por longo prazo, assim, é melhor para os negócios que a empresa faça uso responsável de seu poder social; (iv) os administradores refletem os valores da sociedade na tomada de decisão, portanto, se preocupam com as questões em pauta na comunidade; (v) controle e propriedade estão cada vez mais separados, dificultando a cobrança direta sobre as decisões tomadas na empresa.

É difícil determinar os limites da RSC. De acordo com a equação de igualdade entre poder social e responsabilidade social, a empresa não deve assumir um papel paternalista, buscando resolver problemas da sociedade que não foram causados por ela, nem deve se eximir de qualquer responsabilidade social em prol de aumentar o retorno para o acionista. "Aqueles que não assumirem suas responsabilidades em conformidade com seu poder social, acabarão perdendo-o" (p. 49). A empresa "irresponsável” perderá seu poder para outros atores da sociedade, como governo, sindicatos ou concorrentes. E muitas vezes, a própria empresa acabará arcando com os custos por se eximir de sua responsabilidade (DAVIS, 1967). A teoria de Davis tem mais de 40 anos. De acordo com essa perspectiva, de modo geral, parece que as empresas resolveram assumir suas responsabilidades.

Ventura (2003, p. 4-5) questiona se a RSC não estaria se tornando um discurso e uma prática institucionalizada pelo mecanismo de isomorfismo. Uma suposição é de que, sob o aspecto coercitivo, as organizações mais fortes forçam as empresas de sua cadeia produtiva a adotar práticas similares às suas, no caso, impondo ações que elegem importantes no âmbito da RSC. Sob o aspecto mimético, organizações copiam as práticas de organizações que se julgam de ponta, tentando com isso se livrar das incertezas ambientais. Sob o aspecto normativo, a conscientização dos gerentes e a demanda da sociedade civil que cobra uma postura mais responsável e cidadã fazem as ações organizacionais convergirem para ações mais responsáveis que levem em conta os stakeholders da organização, divulgando e ampliando o 
movimento pela responsabilidade social. Disto deriva outra suposição, a de que, em muitos casos, as organizações lançam-se no discurso da responsabilidade social sem ao menos questionar o que isto significa e sem, verdadeiramente, produzir mudanças reais em suas ações, mas buscando "estampar" aquilo que pode ser divulgado e "condecorado" pela sociedade (e consumidores).

A segunda abordagem desse grupo de teorias analisa a relação empresa-sociedade sob a ótica do contrato social. Assume-se a existência de uma espécie de contrato social implícito entre o negócio e a sociedade (GARRIGA; MELÉ, 2004, p. 56). As relações entre sociedade e empresas baseiam-se em um contrato social que evolui conforme as mudanças sociais e as consequentes variações nas expectativas da sociedade. Nesse contrato, a sociedade legitima a existência da empresa, reconhecendo suas atividades e obrigações, bem como limites legais para sua atuação (BORGER, 2001, p. 38).

Donaldson e Dunfee (1994), baseados na teoria clássica do contrato social, propõem a Teoria do Contato Social Integrativo. A responsabilidade social corporativa é definida em dois níveis: contrato macrossocial e contrato microssocial. O primeiro fornece as regras fundamentais, chamadas hipernormas, para qualquer contrato social, enquanto o segundo traz os acordos implícitos e explícitos firmados entre as partes, por exemplo, empresa e comunidade. O contrato microssocial deve estar em conformidade com o contrato macrossocial para legitimar o acordo.

A última abordagem das teorias políticas é a ideia de cidadania corporativa. Apesar deste termo não ser novo, recentemente houve um aumento de interesse por esse conceito, justificado, entre outros fatores, pela crise do Welfare State e pelo fenômeno da globalização. Esse contexto fez com que algumas multinacionais acumulassem maior poder econômico e social que alguns governos. A estrutura da cidadania corporativa busca considerar essa nova realidade (GARRIGA; MELÉ, 2004, p. 57).

A terminologia cidadania corporativa surgiu na prática vinda dos próprios administradores. Os termos "responsabilidade social" e "ética nos negócios" sugeriam a ausência dessas características nas empresas, por isso os administradores não os adotaram. Mas aceitaram as advertências e críticas para se tornarem socialmente responsáveis e decidiram definir sua própria forma de atuação baseada em ações de uma "boa cidadã corporativa". A academia 
acabou se interessando pelo termo e muitos trabalhos passaram a estudá-lo (MATTEN; CRANE; CHAPPLE, 2003, p. 111).

Entretanto, Matten, Crane e Chapple (2003) propõem uma visão estendida do termo cidadania corporativa. Os autores veem como limitada a visão desse termo na forma como as empresas e a academia utilizam. As grandes empresas adotaram essa "máscara" de cidadania, mas considerando o conceito de cidadania individual, as empresas não partilham dos mesmos direitos e deveres. Na verdade, "por trás da máscara", as empresas gradualmente se promoveram para "substituir a instituição mais poderosa em conceitos tradicionais de cidadania", o governo (p. 117). As empresas, especialmente as grandes corporações, assumiram, com a anuência do Estado, a proteção e facilitação dos direitos sociais, civis e políticos. Portanto, o conceito de cidadania corporativa precisava ser revisto para refletir essa realidade. Retomando a equação de poder de Davis, a empresa tem muito mais poder que os cidadãos, portanto, deve ter também muito mais responsabilidades. Se as empresas estão assumindo o poder do Estado, devem assumir também sua responsabilidade. Mas, como a empresa é movida por interesses próprios, é fundamental que a sociedade cobre transparência e prestação de contas, pois a tendência das corporações é tentar assumir o poder sem assumir suas responsabilidades proporcionais.

Em um país com tamanha desigualdade social como o Brasil, apesar de reconhecer a necessidade de uma conjugação de forças entre Estado, mercado e sociedade civil, deve-se pensar sobre a maneira perversa como o mercado pode atuar, ao assumir o papel de ator principal nessa questão (FONTANELLE, 2006, p.1). Ainda que algumas das ações implementadas pelo empresariado possam ser analisadas como propostas inovadoras e tecnicamente competentes no que toca à redução das carências sociais, elas acabam por deslocar a questão da pobreza da arena pública - onde é analisada como uma questão política mais ampla na qual a noção de cidadania e de direitos tem o seu real sentido - para o campo indeterminado do mercado, onde passam a vigorar como "políticas de exceção" e ficam à mercê de uma lógica de mercado. Ou seja, ela corrói a própria noção do público que, obviamente, traz consequências para o mundo organizacional (ibidem, p. 12).

Para Logsdon e Wood (2002), o conceito de cidadania corporativa é uma transformação do conceito de RSC. Os administradores usavam esse termo para identificar os programas de filantropia englobados no programa de responsabilidade social da empresa. Ainda segundo os 
autores, a cidadania corporativa não é tão robusta moralmente quanto a responsabilidade social corporativa e não serve como um sinônimo adequado. O Quadro 3 mostra a comparação entre os dois conceitos citados e ainda um terceiro conceito criado por eles, a cidadania do negócio (business citzenship).

Quadro 3 - Comparação dos conceitos de RSC, Cidadania Corporativa e Cidadania do Negócio

\begin{tabular}{|c|c|c|}
\hline $\begin{array}{c}\text { Responsabilidade Social } \\
\text { Corporativa }\end{array}$ & Cidadania Corporativa & Cidadania do Negócio \\
\hline $\begin{array}{l}\text { Obrigatório e voluntário: } \\
\text { expectativa que todas as firmas } \\
\text { manterão princípios éticos básicos } \\
\text { e irão beneficiar os stakeholders } \\
\text { "além da lei", de modo a reduzir os } \\
\text { danos e/ou aumentar benefícios. }\end{array}$ & $\begin{array}{l}\text { Exigências legais mínimas, uma } \\
\text { expectativa de "dar alguma coisa } \\
\text { de volta" para a comunidade, am- } \\
\text { plo conjunto de ações voluntárias } \\
\text { aceitáveis, nenhuma aprovação se } \\
\text { não forem realizadas doações. }\end{array}$ & $\begin{array}{l}\text { Obediência obrigatória a } \\
\text { hipernormas, experimentos em } \\
\text { demandas locais, aprendizado } \\
\text { sistemático. Participação voluntária } \\
\text { nos interesses dos stakeholders. }\end{array}$ \\
\hline $\begin{array}{l}\text { Maior interesse das empresas pelas } \\
\text { demandas dos stakeholders e por } \\
\text { "fazer a coisa certa". }\end{array}$ & $\begin{array}{l}\text { Foco limitado na comunidade e } \\
\text { caridade. }\end{array}$ & $\begin{array}{l}\text { Amplo interesse pelas demandas dos } \\
\text { stakeholders. Implicações práticas, } \\
\text { específicas. }\end{array}$ \\
\hline $\begin{array}{l}\text { Vago, difícil de justificar, } \\
\text { operacionalizar, mensurar e } \\
\text { avaliar. }\end{array}$ & $\begin{array}{l}\text { Limitado e específico, mais fácil } \\
\text { de mensurar e defender. }\end{array}$ & $\begin{array}{l}\text { Fornece estrutura clara para } \\
\text { operacionalização, mensuração e } \\
\text { avaliação. }\end{array}$ \\
\hline $\begin{array}{l}\text { Benefícios próprios são possíveis e } \\
\text { aceitáveis, mas não assumidos, e } \\
\text { não são tão relevantes quanto as } \\
\text { responsabilidades moral e legal. } \\
\text { Empresas não têm o direito de } \\
\text { sobreviver. }\end{array}$ & $\begin{array}{l}\text { Benefícios próprios são desejáveis } \\
\text { e talvez essenciais por servir co- } \\
\text { mo incentivo ao comportamento } \\
\text { benéfico para a sociedade. Direito } \\
\text { de sobrevivência das empresas é } \\
\text { assumido. }\end{array}$ & $\begin{array}{l}\text { Benefícios próprios são possíveis, } \\
\text { aceitáveis, desejáveis, mas não essen- } \\
\text { ciais para o exercício das obrigações } \\
\text { de cidadania. Sobrevivência de longo } \\
\text { prazo é incentivo para comporta- } \\
\text { mento socialmente benéfico. }\end{array}$ \\
\hline $\begin{array}{l}\text { Ameaça a teoria econômica } \\
\text { neoclássica de capitalismo. }\end{array}$ & $\begin{array}{l}\text { Reconfortante: conversa com o } \\
\text { "liberalismo contido" e com o } \\
\text { "conservadorismo compassivo". }\end{array}$ & $\begin{array}{l}\text { Símbolos e linguagem convincentes, } \\
\text { afirmação de identidade partilhada, } \\
\text { conexão com pessoas e organizações. }\end{array}$ \\
\hline $\begin{array}{l}\text { Princípios morais são assumidos, } \\
\text { mas ambíguos. Aceitação } \\
\text { questionável. }\end{array}$ & $\begin{array}{l}\text { Princípio de "devolução" à } \\
\text { sociedade por meio de caridade } \\
\text { voluntária é prontamente aceito e } \\
\text { compreendido. }\end{array}$ & $\begin{array}{l}\text { Princípios morais de liberdade e } \\
\text { justiça social e visão de negócio } \\
\text { como secundária e subordinada aos } \\
\text { interesses humanos. }\end{array}$ \\
\hline
\end{tabular}

FONTE: LOGSDON; WOOD, 2002, tradução livre.

Logsdon e Wood (2002) apresentam uma visão mais idealista e depositam na empresa, por meio do conceito de cidadania criado, a possibilidade de melhorar o mundo. Segundo os autores, se a cidadania para as empresas for vista somente como algo "voluntário" com um conteúdo limitado à caridade local ou estratégia baseada em autointeresse, não há chance de corrigir o desbalanceamento de poder social ou evitá-lo. Balancear as demandas de liberdade e justiça é uma tarefa para todas as instituições - empresas, governo, educação, família e religião. Os autores "acreditam" que o conceito de cidadania criado irá mover a sociedade "implacavelmente" em direção aos "objetivos de liberdade e justiça para todos" porque essas são as condições necessárias não somente para o sustento da autonomia humana e da qualidade de vida, mas também para a sustentabilidade do capitalismo em si (p. 185). 
O conceito de cidadania é de uma outra natureza e implica, necessariamente, a superação de interesses particulares, a consciência do bem comum, a noção de igualdade e liberdade, de respeito pelos direitos do outro, bem como o reconhecimento da necessidade da presença de diferentes atores no debate político sobre os negócios da cidade e da nação por inteiro. O político e o social se fundem e se sustentam numa representação, num desejo, num projeto e numa vivência de coletividade capaz de identificar-se como pertencendo àquela, e não a outra sociedade, ou seja, a cidadania é um estatuto entre uma pessoa natural e uma sociedade política, portanto privativo do indivíduo e dos seus direitos/deveres civis. Um sistema artificial como uma empresa, uma associação, pode ter uma nacionalidade, mas certamente não uma cidadania. (FREITAS, 2000, p. $10)$.

Esses conceitos têm traços muito normativos, pois tentam dizer por que e em que extensão as empresas "deveriam" se envolver com a sociedade. Em muitos casos, eles surgiram de atitudes muito críticas com relação às empresas, e o debate nunca transcende as ideologias do negócio orientado para a visão "capitalista" ou do negócio com maior responsabilidade na sociedade, defendido pelas propostas "críticas", "liberais" ou "socialistas" (MATTEN; CRANE; CHAPPLE, 2003, p. 111). Essa ideia pode ser estendida inclusive para a proposta desses autores.

As teorias políticas, considerando a relação empresa-sociedade, têm o foco na sociedade, ao contrário das teorias instrumentais. A postura percebida nessas teorias é da sociedade como o lado frágil dessa relação, como se o poder da empresa fosse muito maior que o poder da sociedade. Entretanto, não se pode esquecer que empresa e sociedade são elos dependentes entre si, e isto significa que a empresa depende da sociedade também. Por isso, a sociedade também pode atuar de maneira corporativa. Isso vem acontecendo com entidades do Terceiro Setor, especialmente em defesa do meio ambiente, que se voltam contra grandes corporações e conseguem atingir seus objetivos. Vale lembrar que, de acordo com a teoria de Davis, se a empresa não assumir as responsabilidades sociais na mesma proporção de seu poder, ela deverá perdê-lo para outra instituição da sociedade que as assuma.

\subsubsection{Teorias Integrativas}

O terceiro grupo teórico definido por Garriga e Melé (2004, p. 52), nomeado pelos autores "teorias integrativas", inclui teorias que consideram papel da empresa integrar as demandas sociais. Argumenta-se que os negócios dependem da sociedade para sua continuidade e crescimento e até mesmo para sua existência. As demandas sociais são derivadas da maneira como a sociedade interage com a empresa e dá a ela legitimidade. Então, o conteúdo da responsabilidade social é limitado a cada situação, dependendo dos valores da sociedade. 
Quatro abordagens são relacionadas neste grupo: (i) administração de demandas, (ii) responsabilidade pública, (iii) gestão de stakeholders e (iv) desempenho social corporativo.

A primeira abordagem, administração de demandas (issues management), surgiu da década de 1970. Inicialmente essa abordagem era restrita à compreensão social, isto é, as empresas reagiam às questões colocadas pela sociedade. Depois a empresa passa a desenvolver tais "reações", e isso se torna um processo de gestão. Alguns assuntos relacionados a esse processo foram estudados posteriormente, como identificação, avaliação e categorização das respostas à sociedade, formalização dos estágios das demandas sociais, resposta corporativa para a mídia com relação às atitudes tomadas, entre outros (GARRIGA; MELÉ, 2004, p. 58).

Ackerman (1973) chama "zona de entendimento" (zone of discretion) o espaço de tempo entre o sinal emitido pela sociedade e ação da empresa. $O$ intervalo existe porque a empresa precisa compreender a demanda social e decidir como agir sem prejudicar seus objetivos principais. Depois da decisão, a empresa passa por um processo de institucionalização, quando ocorre a implantação da decisão, e assume a responsabilidade por suprir uma demanda social.

Sethi (1975) desenvolve uma estrutura para facilitar as decisões sobre ações sociais corporativas. O texto sugere uma racionalização do processo decisório, de modo que a companhia analise as alternativas em termos de relevância social. O comportamento corporativo é descrito como um fenômeno com três estágios baseados na evolução da noção de legitimidade:

- obrigação social é o comportamento corporativo como resposta às forças de mercado ou aos requisitos legais;

- responsabilidade social implica em elevar o comportamento corporativo para o nível de congruência com as normas, valores e expectativas de desempenho social prevalecentes e

- compreensão social direciona o comportamento corporativo para os impactos sociais de longo prazo, isto é, a empresa passa a se antecipar e prevenir possíveis problemas sociais.

Com isso, o autor sugere que as ações da empresa sejam planejadas por esses três estágios com o objetivo de atingir o terceiro nível de legitimidade. 
Jones (1980) defende ser impossível definir responsabilidade social empresarial por ações ou decisões específicas da empresa e afirma que a RSC deve ser analisada como um processo. As companhias "precisam analisar o impacto social de suas decisões antes de tomá-las e incluir medidas para minimizar os custos sociais dessas decisões quando apropriado" (p. 65). Na implementação dessa visão, o autor ressalta a necessidade de dar ênfase às variáveis sociais já na tomada de decisão, portanto, a questão social passa a ser uma variável de entrada no processo decisório e não apenas uma variável de saída ou uma consequência da decisão. Por fim, o próprio autor coloca uma importante limitação da sua proposta: a mudança no processo não implica necessariamente em mudança de comportamento.

Wartick e Rude (1986) mostram a transição da discussão de reação da empresa para a definição da administração de problemas. A proposta dos autores é que a empresa passe de uma posição reativa para uma postura pró-ativa, minimizando as "surpresas" trazidas pelas demandas sociais. A mudança acontece com a formalização das respostas dadas aos problemas sociais. As decisões passam a ser sistematizadas, de modo que estejam coordenadas e integradas com todo o processo decisório da companhia.

A segunda abordagem, responsabilidade pública, é focada apenas na "discussão" de Jones (1980) com Preston e Post (1975, 1981). Preston e Post (1975, apud Jones, 1980, e apud Preston e Post, 1981) analisam a responsabilidade dos administradores em dois níveis de envolvimento com os problemas sociais: primário e secundário. O envolvimento primário está relacionado com as atividades essenciais da empresa: empregar pessoas, contratar fornecedores, transportar produtos, comprar matéria-prima, obter licença de funcionamento, etc. O nível secundário está relacionado aos efeitos indiretos das decisões das empresas que os administradores contemporâneos devem ter consciência, como impactos na comunidade local com a entrada ou saída de uma fábrica, desemprego gerado pela automação da linha de produção, desenvolvimento de produtos com efeitos colaterais, poluição gerada no transporte das mercadorias, etc.

Preston e Post (1975, apud Preston e Post, 1981, p. 57) argumentam que o estabelecimento desses dois níveis de responsabilidade ajudou as empresas a definir uma agenda de responsabilidades sociais, mostrando que não há uma agenda comum a todas as corporações, ao contrário cada empresa desenvolve a sua agenda baseada em princípios éticos. E ainda enfatizou a importância de se estabelecerem limites para a RSC, pois a empresa não deveria 
se envolver com problemas que desconsideram suas características e suas causas. Para estabelecer esses limites, os autores sugerem que as empresas acompanhem as políticas públicas, não apenas as políticas públicas formais, mas também questões emergentes e padrões sociais definidos pela opinião pública.

Jones (1980, p. 62-64) critica os autores porque sua definição das responsabilidades com base em políticas públicas não pode ser adotada como critério para tomada de decisão. As políticas públicas formais, muitas vezes, não são claras, e as informais, geralmente, são permeadas de conflitos sociais e por isso não obtiveram formalização. Além disso, as políticas públicas podem apresentar conflitos inclusive nas apresentações formais, por exemplo, legislação versus código de conduta moral formalizado. Por fim, Jones apresenta quatro exemplos mostrando que a proposta de Preston e Post acaba levando a empresa de volta ao conflito dos limites da RSC.

No ano seguinte, Preston e Post (1981) devolvem a crítica. Preston e Post (1981) usam os exemplos dados por Jones (1980), os quais eles criticam por serem "extremamente simplistas" e diferentes do "mundo real" (p.58), para mostrar que sua teoria é válida para tomada de decisão e sugerem aos críticos o desenvolvimento de uma nova abordagem, incluindo os possíveis conflitos com as políticas públicas.

Não havia necessidade de Garriga e Melé (2004) criarem uma abordagem específica para esses textos, a ideia inicial de Preston e Post (1981), assim como as discussões que seguem, enquadram-se na abordagem anterior em que as empresas buscam administrar as demandas sociais.

A próxima abordagem, gestão dos stakeholders, traz uma das teorias mais utilizadas na literatura de RSC, a teoria dos stakeholders. Emshoff e Freeman (1978) apresentaram o trabalho seminal que trazia dois princípios básicos sobre a administração dos stakeholders: (i) o objetivo maior é atingir a máxima cooperação entre o sistema formado por todos os grupos de stakeholders e os objetivos da empresa e (ii) as estratégias mais eficientes envolvem esforços que tratem simultaneamente demandas relacionadas a múltiplos stakeholders (GARRIGA; MELÉ, 2004, p. 59). 
Freeman e Reed (1983, p. 88-95) mostram como surgiram esses princípios, durante trabalho desenvolvido no Instituto de Pesquisa de Stanford. Os autores analisam também a relação de poder e interesse entre os diversos grupos de stakeholders. O Quadro 4 mostra um resumo desta análise.

Quadro 4 - Mapa dimensional dos stakeholders: poder x interesse

\begin{tabular}{|c|c|c|c|}
\hline & \multicolumn{3}{|c|}{ Poder } \\
\hline & Formal ou Votante & Econômico & Político \\
\hline $\begin{array}{l}\text { Propriedade } \\
\text { (Equity) }\end{array}$ & $\begin{array}{ll}\text { - } & \text { Acionistas } \\
\text { - } & \text { Diretores } \\
\text { - } & \text { Minoritários }\end{array}$ & & - Acionistas dissidentes \\
\hline Econômico & $\cdot$ & $\begin{array}{l}\text { Fornecedores } \\
\text { Clientes } \\
\text { tos }\end{array}$ & $\begin{array}{ll}\text { - } & \text { Governo local } \\
\text { - } & \text { Governo estrangeiro } \\
\text { - } & \text { Grupos de Consumidores } \\
\text { - } & \text { Sindicatos }\end{array}$ \\
\hline Influências & $\begin{array}{ll}\text { - } & \text { Governo } \\
\text { - } & \text { SEC } \\
\text { - } & \text { Outside Directors }\end{array}$ & EPA/OSHA & $\begin{array}{ll}\text { - } & \text { Nader’s Raiders } \\
\text { - } & \text { Governo } \\
\text { - } & \text { Associações de Comércio }\end{array}$ \\
\hline
\end{tabular}

FONTE: FREEMAN; REED, 1983, p. 94, tradução livre (Quadro original está exposto no Anexo C).

Recentemente, as corporações têm sido pressionadas por organizações não governamentais (ONGs), ativistas, comunidades, governo, mídia e outras forças institucionais. Esses grupos reivindicam o que eles consideram ser práticas socialmente responsáveis. Algumas corporações têm procurado respostas para as demandas sociais por meio de diálogos estabelecidos com um amplo grupo de representantes dos stakeholders (GARRIGA; MELÉ, 2004, p. 59).

Diversas teorias tentaram integrar as abordagens vistas nesse grupo. A abordagem do desempenho social corporativo é fruto dessas tentativas. Essa abordagem inclui a busca pela legitimidade social (GARRIGA; MELÉ, 2004, p. 60).

Legitimação envolve não somente o tipo de atividade corporativa, mas também o processo interno de tomada de decisão; a percepção do ambiente externo; a manipulação do ambiente externo físico, social e político - para torná-lo mais receptivo às atividades corporativas; e a natureza da prestação de contas para outras instituições sociais do sistema. ${ }^{9}$ (SETHI, 1975, p. 60, tradução livre).

\footnotetext{
${ }^{9}$ Legitimization involves not only the type of corporate activities, but also the process of internal decision making; the perception of external environment - physical, social and political - to make it more receptive to corporate activities; and the nature of accountability to other social institutions in the system (SETHI, 1975, p. $60)$.
} 
Carroll (1979) desenvolveu um modelo conceitual, sugerindo três aspectos fundamentais do desempenho social corporativo: uma definição básica de responsabilidade social, uma enumeração de demandas pelas quais a responsabilidade social existe e uma descrição da "filosofia de resposta" das companhias, que pode variar de reativa à pró-ativa (p. 499). A definição de responsabilidade social dada pelo autor nesse texto inclui quatro dimensões que devem existir simultaneamente nas organizações:

- responsabilidade econômica - antes de tudo, a empresa é uma unidade econômica na sociedade com a responsabilidade de produzir bens e serviços, conforme a demanda, e operar com lucros;

- responsabilidade legal - a empresa deve atender totalmente às normas legais estabelecidas pela sociedade, é uma parte do "contrato social" que permite a operação da firma como unidade econômica no sistema social;

- responsabilidade ética - a empresa deve respeitar as normas éticas da sociedade, mesmo que não estejam estabelecidas legalmente (o que dificulta sua ação responsável, pois as normas éticas nem sempre são claras e unânimes);

- responsabilidade discricionária - a empresa pode atender voluntariamente a demandas discricionárias da sociedade, deve-se considerar a existência de expectativas com relação às ações sociais da companhia, apesar de não haver obrigações legais nesse quesito.

Mais de uma década depois, Carroll (1991) retoma essas definições e transforma a responsabilidade discricionária em cidadania corporativa. $\mathrm{O}$ autor transforma o discurso do texto anterior (CARROLL, 1979) para a visão de legitimação perante os stakeholders e coloca a pirâmide de RSC como uma ferramenta de orientação para a tomada de decisão (Ilustração 2). Além disso, o autor defende a administração moral em contraposição à imoral e à amoral.

Wartick e Cochran (1985) revisam a literatura e propõem um novo modelo, buscando integrar os princípios de responsabilidade social com os processos de resposta da empresa às demandas sociais e ainda com as políticas sociais desenvolvidas na companhia para "fornecer uma visão distinta de todos os esforços da empresa para satisfazer suas obrigações com a sociedade" (p. 758). Os autores sintetizam as visões de Davis (1967), Carroll (1979) e Preston e Post (1981) para propor mais um modelo. Nesse, a responsabilidade social é vista como uma base filosófica e ética de orientação da empresa; o sistema de respostas às demandas 
sociais é um processo de aprendizagem para desenvolver a "filosofia de respostas"; e a administração de demandas é a prática efetiva da responsabilidade social.

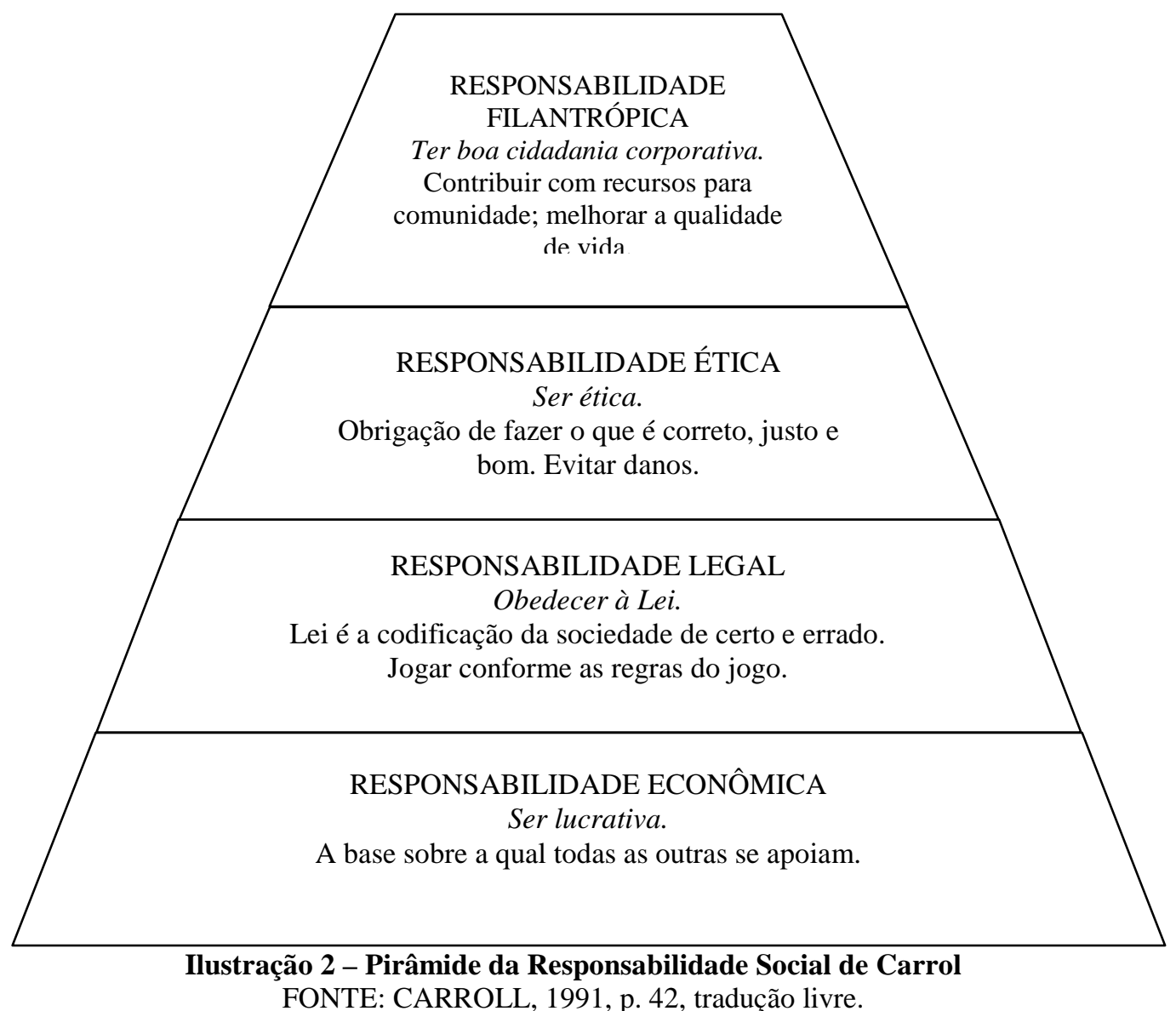

Wood (1991) propõe mais um modelo. Essa proposta articula princípios, práticas e resultados para entender o desempenho social corporativo. Os princípios são divididos em três níveis: (i) institucional, baseia-se na busca de legitimidade; (ii) organizacional, busca atender à ideia de responsabilidade pública; (iii) individual, pauta-se nas responsabilidades individuais do administrador. As práticas seguem a mesma linha e estão divididas em avaliação do ambiente, gestão de stakeholders e administração das demandas sociais. Ainda com a mesma ideologia, a autora propõe a avaliação de resultados por meio de análise das políticas sociais, dos programas sociais e dos impactos causados pelo comportamento organizacional. A proposta de avaliação de resultados é a parte inovadora do modelo proposto por Wood (1991).

Já no modelo de Enderle e Tavis (1998), a inovação está em focar resultados de longo prazo. Os autores defendem que o equilíbrio entre as responsabilidades econômica, ambiental e social acontece quando existe busca da maximização do valor de longo prazo da companhia. 
A ênfase maior nesse texto está na avaliação de resultados e no necessário desenvolvimento de indicadores capazes de mensurar o impacto de longo prazo das ações sociais e ambientais.

Quazi e O’Brien (2000) propõem um modelo bidimensional de RSC em que uma das dimensões é a amplitude da responsabilidade corporativa (de ampla a restrita) e a outra, a variação da relação custo-benefício da ação social (de custo a benefício líquido). A proposta classifica diferentes visões de responsabilidade social, conforme o posicionamento no modelo (Ilustração 3).

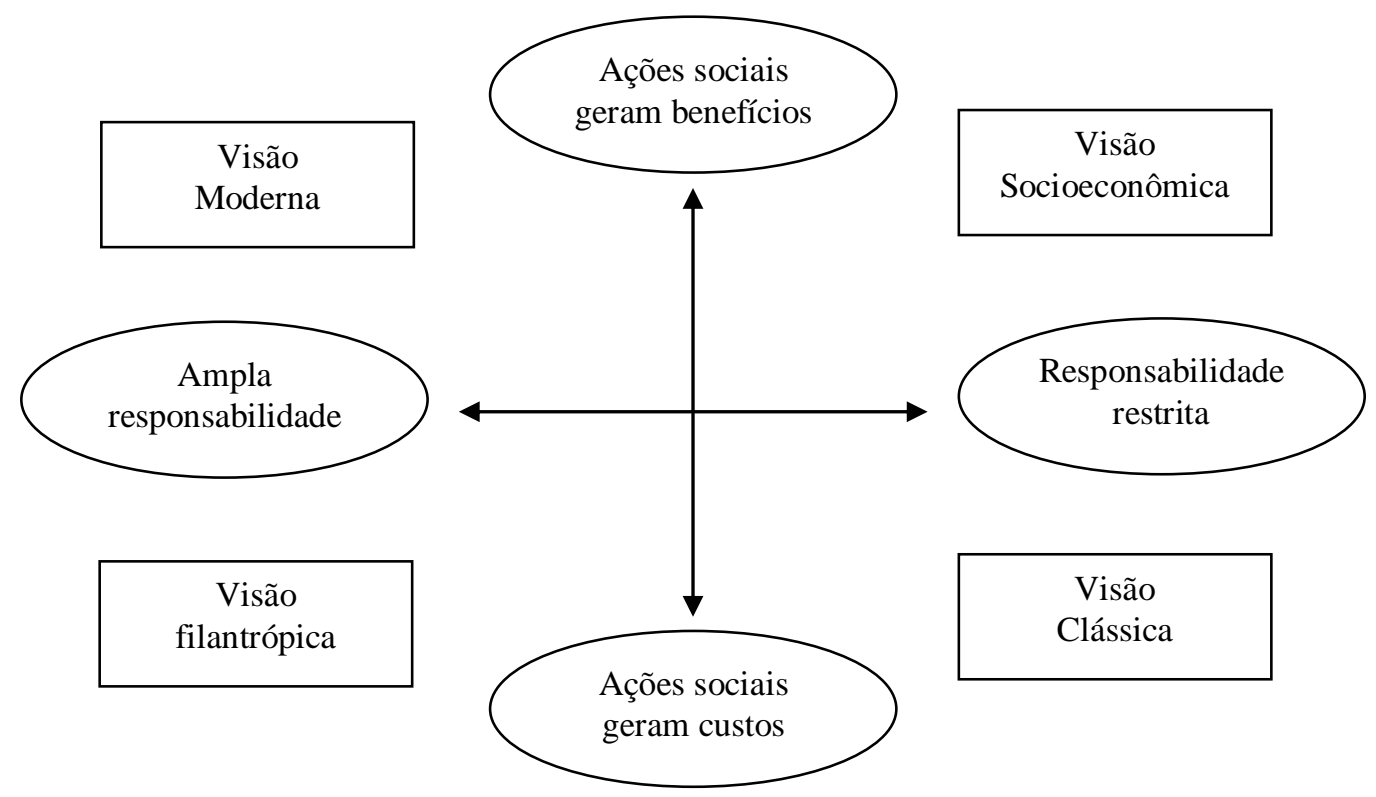

Ilustração 3 - Comparação do modelo tradicional da empresa com o modelo dos stakeholders FONTE: Quazi e O'Brien (2000, p. 36)

Pereira e Campos Filho (2006) estudaram similaridades entre modelos teóricos de RSC. Os autores analisaram quatro modelos conceituais: Carroll (1979 e 1991), Enderle e Tavis (1998), Quazi e O’Brien (2000) e Wood (1991). Quanto às similaridades, os autores destacam:

- a convergência das dimensões Econômica e Legal preconizadas por Carroll (1979, 1991) com a dimensão Econômica de Enderle e Tavis (1998) e a Visão Clássica defendida por Quazi e O’Brien (2000);

- a convergência do modelo de Wood (1991) com a dimensão Social de Enderle e Tavis (1998) e a Visão Sócioeconômica defendida por Quazi e O’Brien (2000); 
- a convergência da dimensão ética do modelo de Carroll $(1979,1991)$ com a dimensão Ambiental de Enderle e Tavis (1998) e a Visão Moderna apresentada por Quazi e O’Brien (2000) e

- a convergência da dimensão discricionária do modelo de Carroll $(1979,1991)$ com a Visão Filantrópica preconizada por Quazi e O’Brien (2000).

Esse grupo de teorias mostrou a necessidade de a empresa se relacionar com a sociedade. Esse é o grupo que considera as relações sociais da empresa como essenciais para alcançar o objetivo principal do negócio. É importante ressaltar que nenhuma das abordagens deixa de lado a necessidade de lucro nos negócios, mesmo alguns autores apresentando visões mais ideológicas. Deve-se atentar para não perder o foco do negócio quando se observa esse grupo de teorias, por isso, o ponto crítico é definir os limites da RSC, isto é, até que ponto a empresa pode/precisa se envolver com as questões sociais filantrópicas sem perder seu foco.

\subsubsection{Teorias Éticas}

Por fim, o quarto e último grupo teórico definido por Garriga e Melé (2004, p. 53), "teorias éticas", abrange teorias que percebem a relação entre a empresa e a sociedade permeada de valores éticos. Isto leva a enxergar a RSC de uma perspectiva ética e, como consequência, as empresas devem aceitar suas responsabilidades sociais como uma obrigação ética acima de qualquer outra consideração. As teorias desse grupo são baseadas em princípios que expressam a "coisa certa a fazer" ou a necessidade de buscar o "bem da sociedade" (p. 60). Novamente quatro abordagens são destacadas: (i) teoria normativa dos stakeholders, (ii) direitos universais, (iii) desenvolvimento sustentável e (iv) busca do bem comum.

Garriga e Melé (2004, p. 60) justificam a inclusão da teoria de gestão dos stakeholders como uma teoria integrativa porque alguns autores assim a consideram, mas a teoria de gestão dos stakeholders tornou-se uma teoria ética a partir da publicação do livro "Strategic Management: a Stakeholder Approach" por Freeman em 1984, porque o autor adota uma visão mais voltada ao relacionamento entre os grupos. Apesar da justificativa dada pelos autores, não é possível notar tal diferença nos textos de Freeman. Sua definição, tanto da teoria quanto de stakeholders, mantém-se a mesma nos textos de 1983, 1994 e 2002. Assim, 
adotou-se a divisão por tempo (ano) entre a perspectiva anterior e essa, apenas para continuar seguindo a classificação dos autores.

Donaldson e Preston (1995, p. 68-69) fazem uma comparação do tradicional processo de entradas e saídas das empresas (input-output) com a teoria dos stakeholders (Ilustração 4). Segundo eles, todas as pessoas ou grupos com interesses legítimos que participam do negócio buscam obter benefícios e não há prioridade de um sobre o outro. A teoria dos stakeholders busca explicar e orientar a empresa na administração desses múltiplos interesses.

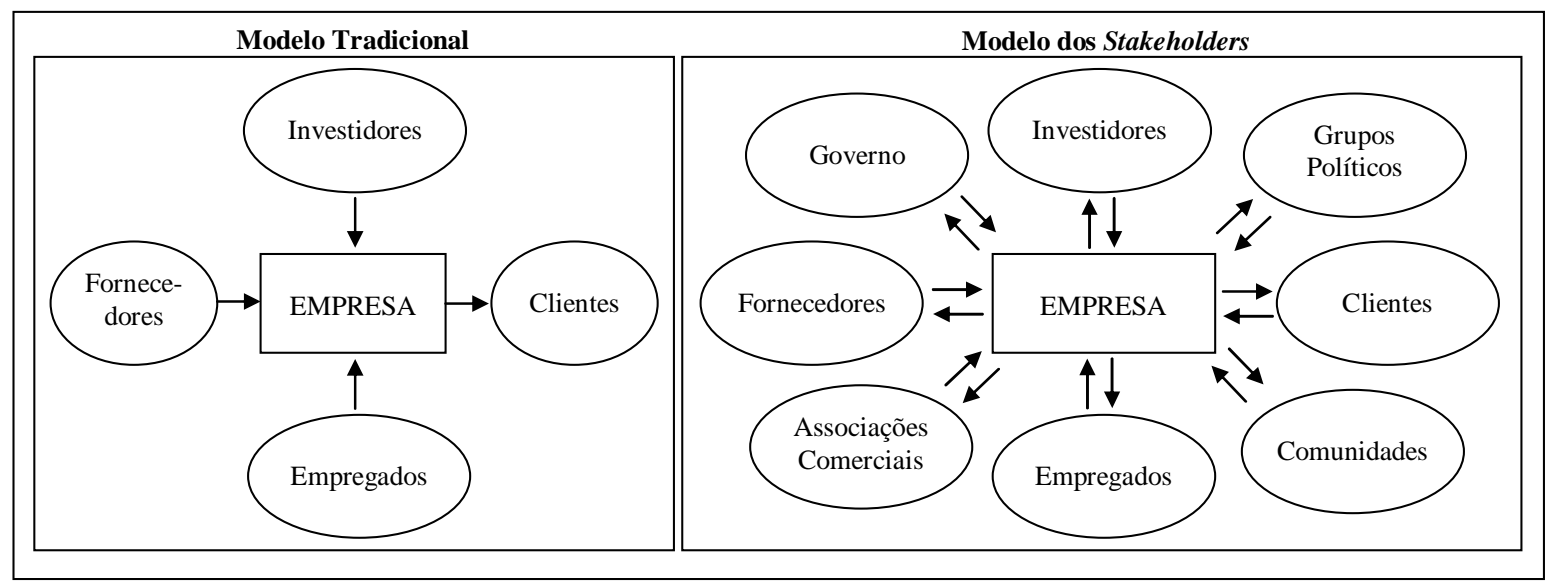

Ilustração 4 - Comparação do modelo tradicional da empresa com o modelo dos stakeholders FONTE: DONALDSON; PRESTON; 1995, p. 68-69, tradução livre.

Para Donaldson e Preston (1995), a teoria dos stakeholders pode ser definida em três níveis:

- descritivo: a teoria explica e descreve a relação da empresa com os stakeholders observados,

- instrumental: a teoria busca explicar e prever o impacto da administração dos stakeholders no desempenho corporativo,

- normativo: a teoria dá suporte à gestão porque analisa a função da empresa por meio de pressupostos filosóficos e morais dos stakeholders.

Bowie (1991) defende a divisão de responsabilidades entre os stakeholders. Ele acredita que a empresa não tem condições e nem recursos para resolver os problemas sociais e seu envolvimento com essas responsabilidades só é coerente quando o mercado competitivo exige isso e o governo não é capaz de atender às necessidades. Ele ainda defende que se a empresa tem responsabilidades com os stakeholders, estes também as têm com a empresa. 
A teoria dos stakeholders é tipicamente burguesa, já que o mundo é visto da perspectiva do administrador da organização que está estrategicamente preocupado com a continuidade do sucesso da companhia. Sob esta perspectiva, a continuidade da organização requer o suporte dos stakeholders, e sua aprovação passa a ser um objetivo da companhia. Quanto maior o poder dos stakeholders, mais a empresa buscará se adaptar às suas necessidades. Com isso, a divulgação de informações socioambientais passa a ser uma forma de diálogo com esses grupos. Realmente, sob a ótica da organização, essa abordagem é mais adequada para teorizar a relação empresa-sociedade. Entretanto, essa análise falha por não reconhecer as desigualdades nesses relacionamentos (GRAY; KOUHY; LAVERS, 1995a, p. 53).

Evidentemente, sempre existiu um grande abismo entre o mundo das intenções e a realidade cotidiana. As organizações são produto e produtor dos ambientes em que atuam. A competitividade atual não apareceu do nada, e são as próprias empresas que dela participam que estabelecem as regras. Quando o ambiente começa a se tornar nocivo ao próprio jogo, é preciso modificar o ambiente para que o jogo possa continuar. O modelo que consagra aquele que ganha de qualquer jeito tende a esgotar-se. Não existem anjos nem inocentes nesse jogo, mas existem conveniências e a necessidade de um mínimo de credibilidade para que as organizações possam operar, gerar lucros, crescer e expandir (FREITAS, 2000, p. 13).

É sempre nebuloso em que ponto a teoria dos stakeholders termina e começa a teoria da legitimidade (GRAY; KOUHY; LAVERS, 1995a, p. 66). Lindblom (1994, apud Gray, Kouhy e Lavers, 1995a, p. 54) analisa a teoria da legitimidade e enfatiza a diferença entre legitimidade, um estado ou condição, e legitimação, uma ação ou um processo. Assim, uma empresa adota uma estratégia de legitimação quando percebe uma lacuna de legitimidade, isto é, quando a legitimidade observada é diferente da desejada. A autora identifica quatro estratégias de legitimação que uma empresa pode adotar.

$1^{\circ}$. A organização pode procurar educar e informar seu "público relevante" sobre mudanças (reais) nas atividades e no desempenho da companhia. Essa estratégia é escolhida em resposta a uma lacuna de legitimidade originada por falha no desempenho da organização.

$2^{\circ}$. A organização pode procurar mudar a percepção do público relevante - mas não mudar seu verdadeiro comportamento. Essa estratégia é adotada quando a organização constata que a lacuna de legitimidade surgiu devido a uma percepção errônea por parte do público relevante. 
$3^{\circ}$. A organização pode procurar manipular a percepção do público relevante, desviando sua atenção de questões de interesse para outras questões relacionadas por meio de apelação, por exemplo, para símbolos emotivos. Essa estratégia é escolhida por intenções de manipulação. Um exemplo seria uma companhia com lacuna de legitimidade devido a sua contribuição para a poluição local optar por ignorar sua característica poluidora e divulgar projetos "filantrópicos" de educação ambiental.

$4^{\circ}$. Quarto, a companhia pode procurar mudar as expectativas externas com relação a seu desempenho. Essa estratégia é escolhida quando a empresa considera as expectativas de seu público relevante com relação a suas atividades irreais ou incorretas.

Essas estratégias de legitimação podem explicar a necessidade de a empresa divulgar suas ações sociais. Atualmente, até as peças publicitárias tiraram o foco dos produtos e passaram a vender a empresa e sua preocupação com sociedade e meio ambiente. Ventura (2003) questiona a legitimidade que sociedade e academia atribuem à RSC, pois qualifica os investimentos sociais como estratégia empresarial que "encobre" o processo de acumulação capitalista frente à sociedade.

No caso da responsabilidade social, o movimento surge como resultado da crítica à forma pela qual as empresas se relacionam com a sociedade, tirando dela (dos seus recursos) seu lucro, para os acionistas e controladores, mas pouco beneficiando-a ou até causando-lhe danos. Em resposta, o movimento pela responsabilidade social (re)cria provas e dispositivos que, ao operar um deslocamento, desmantela a crítica. São criados institutos para lidar com o assunto, de forma isomórfica às empresas; são instituídas certificações na área social, como a SA8000 e AA1000, balanços, selos, concursos; ou seja, todo um conjunto de regras e convenções, dispositivos para categorizar e classificar as empresas em relação a seu comportamento socialmente responsável, onde são exigidos e valorizados aspectos que, em última instância, os próprios capitalistas elegem, sem prejuízo para a lucratividade. [...]

Ou seja, como resposta à crítica, dentro do movimento pela responsabilidade social, as empresas passam a investir em ações sociais e a divulgar seus padrões éticos, justificando e criando provas à sociedade (e consumidores) de que estão indo ao encontro das aspirações sociais. (VENTURA, 2003, p. 10).

As teorias dos stakeholders e da legitimidade são as mais discutidas recentemente nos trabalhos sobre RSC. As duas, junto com as teorias econômicas, parecem ser as que melhor conseguem explicar as ações sociais corporativas.

A segunda abordagem desse grupo de teorias traz a questão dos direitos universais. A proposta de Garriga e Melé (2004, p. 61) para a abordagem dos direitos universais trata de legislação e declaração de direitos universais. O tema tem relação estreita com as empresas e com o Estado, especialmente por ser uma das formas de regulação do mercado pelo Estado. A 
interface mais prática do tema com as empresas são as certificações socioambientais, como SA8000, que fiscalizam a postura da empresa em relação aos direitos universais. Alguns críticos dessas certificações (veja Macedo, 2005) acreditam ser uma maneira de rotular os produtos brasileiros e criar uma barreira de entrada em outros mercados, além de se criar um custo adicional para as empresas sem, algumas vezes, o selo ser de fato um diferencial (pois se cria um mercado de "compra e venda"). A garantia dos direitos universais em fatores relacionados à empresa é uma obrigação legal, e não seria necessária certificação, mas sim fiscalização do governo.

A terceira abordagem, desenvolvimento sustentável, ganhou muita visibilidade nos últimos anos. O desenvolvimento sustentável tem dois princípios fundamentais: o tripé de sustentação do desenvolvimento envolve as dimensões econômica, social e ambiental, e a ação da empresa hoje não pode prejudicar as gerações futuras. Os textos sugeridos nessa abordagem não sugerem diferenciais sob a ótica dos objetivos deste capítulo. É um assunto importante, mas percebe-se que muitas discussões são releituras dos conceitos tradicionais de RSC com maior apelo para a vertente ambiental.

A última abordagem sustenta o bem comum da sociedade como o valor referencial da responsabilidade social corporativa. Sustenta-se que a empresa, como qualquer outra instituição social, deve contribuir para o bem comum. Os negócios não devem ser prejudiciais nem "parasitas" da sociedade (GARRIGA; MELÉ, 2004, p. 62). Os negócios podem contribuir para a sociedade somente por atingir seu objetivo de maximizar o valor do acionista de maneira ética ou pode contribuir por meio de ações sociais para seus stakeholders.

Para Freitas (2000, p.13), o movimento pela ressurreição da ética leva a supor que o ambiente estava se tornando mortífero e que as condições mínimas de confiabilidade estavam perecendo. As organizações modernas apresentam-se agora não apenas como o modelo de gestão eficaz que deve ser seguido pelas demais instituições da sociedade, mas também como as guardiãs dos valores sociais mais elevados e da moralidade pública. "É impressionante a maneira como as organizações modernas buscam transformar a necessidade em virtude."

O tratamento de problemas sociais complexos não se resume em uma gestão eficiente dos recursos financeiros. A produção de transformação social vai além da implementação de programas sociais, exigindo uma nova postura de atuação das empresas no campo da gestão 
social, com destaque para a geração de capital social e desenvolvimento local. Por isso, faz-se necessário criar uma rede de atuação no campo social onde a sociedade seja vista como um todo e não de forma fragmentada (MACKE; CARRION, 2006, p.14-15).

Faria e Sauerbronn (2008, p.18-20) separam três diferentes abordagens da responsabilidade social em sua leitura da revisão bibliográfica. A primeira é a abordagem normativa que surge da escola da ética nos negócios e se baseia no argumento de que as empresas estão sujeitas ao julgamento moral. A segunda abordagem, a contratual, se caracteriza por um enfoque sociopolítico e privilegia os interesses e conflitos dos diferentes grupos de atores sociais com os quais a empresa interage. "Essa abordagem traz a sociedade para o primeiro plano e desafia a abordagem normativa, a qual tem a sociedade apenas como recipiente/beneficiária de grandes princípios morais, tais como a justiça ou a igualdade.” (p. 19). Por fim, a abordagem estratégica tem como foco principal a produção de ferramentas de gestão que sejam capazes de melhorar o desempenho social e ético das empresas. "A ênfase está, quase sempre, no aproveitamento de oportunidades e na minimização de riscos, por meio da identificação e resposta a questões de cunho ético e social que podem causar impacto à empresa." (p. 20). Nessa abordagem, a ideia é transformar comportamento socialmente responsável em vantagem competitiva que permita o alcance dos objetivos estratégicos da organização.

Em suas conclusões, os autores alertam para o risco de ter a abordagem estratégica sobrepondo a abordagem contratual de RSC. Os autores alertam que a importação dos conceitos de RSC da literatura americana, sem um olhar crítico e sem as adaptações necessárias para o contexto brasileiro, pode gerar uma apropriação dos interesses públicos pelos interesses corporativos. E defendem uma participação mais ativa do Estado e da sociedade civil no campo organizacional, na tentativa de promover um equilíbrio de interesses.

\footnotetext{
Fortalecer a "abordagem estratégica" na área de estratégia significa garantir o domínio da bagagem importada e não reconhecer que a área é um campo organizacional constituído e disputado por atores de diferentes naturezas e altamente dependentes do poder político, econômico e ideológico das grandes corporações. Suprimir a importância da abordagem contratual é deixar de lado um caráter mais pluralista e menos assimétrico das práticas organizacionais e do conhecimento acadêmico. (FARIA; SAUERBRONN, 2008, p.28).
}

O grupo de teorias éticas, proposto por Garriga e Male (2004), poderia ser fundido com o grupo das teorias integrativas. Aparentemente, as teorias éticas têm o mesmo conteúdo das 
teorias integrativas, apenas melhoram a interface com o usuário, ou seja, aproximam a linguagem da empresa à linguagem da sociedade. Enquanto as teorias integrativas apresentavam claramente a maneira como a empresa enxerga a situação, as teorias éticas mostram um comportamento adequado esperado das empresas, que nada mais é do que a incorporação pelas empresas dos discursos de responsabilidade socioambiental em pauta na sociedade.

Conforme mostrado, diversas teorias tentam explicar a decisão de (não) investir da empresa. As teorias instrumentais são as mais diretas: a empresa só investe quando há perspectivas de maximização dos lucros, seja em curto ou longo prazo. Portanto, o motivo está claro: obter lucros. As teorias políticas mostram o interesse da empresa pelo poder. Não existe altruísmo, nem mesmo na abordagem da cidadania corporativa, o motivo do investimento é aumentar o poder social, pois isso melhora as condições de negociação da empresa. As teorias integrativas mostram o reconhecimento pela empresa de sua dependência da sociedade, mais especificamente, dos stakeholders. O motivo de a empresa investir em RSC é obter legitimidade, pois isso melhora as relações com os stakeholders e, consequentemente, aumenta a produtividade e melhora as condições de negociação. Por fim, as teorias éticas também mostram que a empresa busca legitimação com seus investimentos sociais. Portanto, os motivos das empresas para realizar investimentos sociais tangenciam frequentemente os objetivos de maximizar os lucros e legitimar o poder social e a imagem da empresa junto aos stakeholders.

O Instituto de Pesquisa Econômica Aplicada (IPEA) realizou uma pesquisa qualitativa por meio de entrevista estruturada com responsáveis por ações sociais em 47 empresas da região Sudeste do Brasil, sendo 34 com mais de 500 empregados. Entre outras questões o estudo indagou os motivos do envolvimento com ações sociais e concluiu:

Bondade ou Interesse? Nem um, nem outro, exclusivamente. As motivações [para a ação social empresarial] são complexas e interdependentes. Questões de foro íntimo, como o espírito humanitário, a vontade de dar, de retribuir benefícios recebidos, influenciam, e muito, o envolvimento dos empresários no atendimento social. Ajudar gratifica, e essa satisfação altruísta não deve ser negada ao se tentar entender o comportamento do setor privado na área social.

No entanto, fatores de caráter filantrópico, que sempre estiveram presentes no meio empresarial, não são suficientes para explicar o crescente envolvimento dos empresários com os problemas sociais. Não por acaso, as empresas ampliaram na década de 1990 sua participação na realização de ações sociais para a comunidade. Esse período foi marcado por inúmeras mudanças nas estratégias empresariais, com o objetivo de atender às novas exigências de uma economia 
globalizada na qual o país se inseria. Entre essas novas exigências surge a questão da responsabilidade social como fator de competitividade, ou seja, empresas socialmente ativas promovem sua imagem junto aos consumidores, melhoram o relacionamento com as comunidades vizinhas e percebem ganhos de produtividade de seus trabalhadores. (PELIANO, 2001, p. 33).

Silva Filho (2000) estudou a teoria econômica de maximização do autointeresse com uso de teoria dos jogos e evidencia que a maximização do autointeresse não explica em todos os casos o comportamento dos indivíduos.

\begin{abstract}
Os modelos econômicos tradicionais presumem que as pessoas maximizam sua própria renda sem considerar normas sociais e questões como justiça e reciprocidade. Esta hipótese é parcimoniosa e facilita a análise. Entretanto, em várias situações econômicas estes modelos geram previsões de comportamento não realistas. Um grande número de experimentos com o jogo de ultimato e o jogo ditatorial demonstrou que geralmente não é possível prever o comportamento individual apenas por meio da teoria da maximização de renda. As forças sociais podem ter efeitos substanciais nas decisões econômicas dos indivíduos. Mostramos casos nos quais os jogadores, ao invés de focar seu auto-interesse, seu próprio retorno, parecem responder em termos relacionados à utilidade social, mostrando consideração com relação à justiça e às intenções percebidas dos outros jogadores. (SILVA FILHO, 2000, p. 60).
\end{abstract}

Portanto, os administradores podem envolver valores morais na tomada de decisão, pois a decisão é pessoal. Segundo Davis (1960, p. 75), os administradores tipicamente usam três sistemas de valor isolados na tomada de decisão com primordiais considerações ético-morais: (i) técnico, baseado em fatos físicos e lógica científica, (ii) econômico, baseado em valores de mercado determinados pelos consumidores e (iii) relações humanas, baseado nas necessidades sociopsicológicas, outras além das necessidades de consumo. Em muitas decisões cada um dos sistemas exerce diferente peso para a solução final. Porque o administrador é humano, esse aspecto da sua vida não pode ser ignorado por nenhuma instituição que negocia com ele.

Isso é verdade para pequenas e médias empresas com poder centralizado. As grandes corporações têm decisões tomadas por mais de uma pessoa, o que reduz o peso do fator humano, e muitas vezes possuem um padrão de tomada de decisão, minimizando a influência de julgamentos morais. Além disso, os administradores, como agentes, têm suas remunerações associadas à maximização de valor, por isso, a racionalidade na tomada de decisão aumenta. Mas, ainda que um administrador tome a decisão do investimento social porque acredita na causa e não pelo benefício para a empresa, o investimento deverá ser usado depois para promoção da companhia, pois a característica econômica é inerente aos administradores. 
A sociedade ganha na maior parte das vezes com esses investimentos. As empresas usam estratégias do tipo ganha-ganha, isto é, a empresa ganha e a sociedade também. A empresa exerce o papel de "arrecadadora de fundos" para as causas sociais. A relação custo-benefício é positiva para a sociedade e para a empresa. Para a empresa existe, no mínimo, melhoria da imagem e, consequente maximização do valor da empresa em longo prazo. A sociedade ganha porque recebe gratuitamente um produto ou serviço que deveria ser pago pelas pessoas ou pelo governo.

Os quatro grupos de teorias analisados neste tópico, Responsabilidade Social Corporativa, mostram a grande diversidade de teorias existentes. Em uma análise geral dos trabalhos estudados, tem-se a impressão de que os autores querem corrigir as limitações das teorias anteriores e sempre propor uma nova teoria. Entretanto, em poucos trabalhos percebe-se um crescimento real dos conceitos. A grande maioria dos textos analisados tem as características da pesquisa normativa, de fato esta parece adequada para começar a estudar o assunto. Mas esse tema existe há mais de 50 anos. Talvez o momento seja de realizar um grande volume de estudos empíricos positivos para tentar provar ou refutar essas teorias. Contudo, as pesquisas empíricas nesta área têm a limitação de não haver banco de dados constituídos. Cada pesquisa realizada precisa compor seu banco de dados. O que se percebe no Brasil é que os bancos de dados são formados, mas não disponibilizados, e então cada pesquisa tem de começar novamente da estaca zero (exceção deve ser feita: a FIPECAFI tem grande disposição em ceder as informações do banco de dados 'Melhores e Maiores', mas ainda são poucas as informações socioambientais disponíveis - apenas com relação à DVA já existe volume consistente de informações). Nesse contexto, talvez seja mais importante atualmente a consolidação da "prestação de contas" de informações socioambientais, para que haja mais estudos empíricos sobre o assunto. O próximo tópico irá analisar os modelos de Balanço Social em vigor no Brasil.

\subsection{Balanço Social}

Grande parte das empresas de capital aberto divulga em suas páginas na Internet relatórios socioambientais. Esses relatórios trazem informações pertinentes às ações socioambientais praticadas pela empresa em determinado período (geralmente anual). Em sua maioria, eles 
apresentam mais informações qualitativas que quantitativas, não apresentam informações auditadas (algumas vezes as informações não são verificáveis) e possuem interface agradável ao usuário, pois são coloridos e com muitas fotos dos projetos realizados.

Siqueira e Vidal (2003, p. 12) afirmam que "a atual concepção dos balanços sociais brasileiros se aproxima mais de um instrumento de marketing do que de uma demonstração com real possibilidade de medir o impacto social de uma organização". E, ainda, os consideram instrumentos de mensuração e evidenciação falhos em externar aos usuários o verdadeiro impacto das organizações na sociedade, seja este positivo ou negativo. Seria necessária a realização de mudanças no enfoque para que os relatórios sociais pudessem ser considerados instrumentos de mensuração não enviesados da responsabilidade social das empresas.

O Balanço Social deve abordar quatro vertentes: Recursos Humanos, Relação com a Comunidade, Demonstração do Valor Adicionado e Balanço Ambiental. A vertente de Recursos Humanos, também chamado Balanço das Pessoas, busca evidenciar como a empresa se relaciona com seus funcionários: quais os benefícios, qual a diversidade entre eles, qual a desigualdade entre eles, qual a variação no nível de emprego etc. (FIPECAFI, 2007, p. 10).

A vertente de Relações com a Comunidade busca evidenciar as ações e os investimentos voltados para a comunidade, ou seja, para pessoas não diretamente relacionadas à organização. Essa vertente mostra as doações para entidades sem fins lucrativos, os incentivos e patrocínios à cultura, ao esporte e à educação entre outros.

A Demonstração do Valor Adicionado (DVA) tem o objetivo de evidenciar quanto a empresa agrega de valor à economia, como esse valor é agregado e, especialmente, como o valor agregado é distribuído entre os fornecedores dos fatores de produção (capital e trabalho). A distribuição do valor adicionado remunera os empregados (fator trabalho), o capital de terceiros, o capital próprio (acionistas) e o governo. Assim, essa demonstração evidencia a contribuição da empresa para o desenvolvimento local, mostrando como ela distribui a renda gerada no negócio.

Por fim, a última vertente (a ordem das vertentes não é padronizada e nem reflete maior importância a um dos fatores) é o Balanço Ambiental ou o Balanço Ecológico. O objetivo do 
Balanço Ambiental é evidenciar os eventos econômico-financeiros de natureza ambiental bem como os impactos das atividades da empresa no meio ambiente. Apesar de ainda não haver legislação sobre esse relatório, existem muitas instituições divulgando diretrizes de como e que tipo de informação divulgar. Ribeiro (2006) destaca seis modelos de Balanço Ambiental.

Há pouco tempo, as empresas não se preocupavam em ser transparentes, atualmente elas divulgam relatórios não obrigatórios para evidenciar o que têm feito pela sociedade. "Embora se percebam, de fato, excessos de marketing, é preciso reconhecer o fator positivo: a informação prestada tem estimulado os concorrentes a realizar ações semelhantes ou melhores, o que resulta, portanto, no benefício da sociedade como um todo." (RIBEIRO, 2006, p.108). Certamente houve um ganho para os stakeholders das empresas.

Entretanto, a proliferação dos relatórios foi mais rápida que sua padronização. Isso permite que as empresas evidenciem apenas informações convenientes para si. Os estudos de responsabilidade social enfrentam agora dois desafios: tornar as ações socioambientais verificáveis e comparáveis, isto é, os relatórios emitidos precisam de um padrão que permita auditoria (como ocorre com os selos e certificações) e comparabilidade com outras organizações. Algumas grandes iniciativas já ocorreram e vêm sendo consolidadas. Duas delas merecem destaque e serão abordadas neste tópico, o modelo de Balanço Social do Ibase e o modelo GRI.

O modelo de Balanço Social do Ibase aborda as quatro vertentes, ainda que de maneira condensada. O Instituto Brasileiro de Análises Sociais e Econômicas (Ibase) consolidou, a partir de 1997, com o sociólogo Betinho a ideia que vinha sendo discutida isoladamente desde a década de 1970. Nesse ano, Betinho lançou uma campanha pela divulgação voluntária do balanço social e foi bem-sucedido. Desde então um número substancial de empresas já aderiu a esse modelo. O anexo D traz o modelo apresentado pela instituição.

O Modelo Ibase é um relatório simples, são apenas duas páginas, com indicadores muito objetivos e apoiados nos quatro pilares do Balanço Social: Indicadores Sociais Internos, Indicadores Sociais Externos, Demonstração do Valor Adicionado e Balanço Ambiental. Além disso, o balanço traz alguns questionamentos relacionados à postura ética da empresa. 
Outra iniciativa é o Modelo GRI. A Global Reporting Iniciative (GRI), fundação institucionalizada em 1997, foi criada para estabelecer diretrizes na elaboração de relatórios de sustentabilidade. "Um relatório de sustentabilidade baseado nas Diretrizes da GRI divulga os resultados obtidos dentro do período relatado, no contexto dos compromissos, da estratégia e da forma de gestão da organização." (GRI, 2006, p.4.).

\begin{abstract}
A urgência e a magnitude dos riscos e dos danos para a nossa sustentabilidade e a grande disponibilidade de opções e oportunidades tornarão a transparência sobre os impactos econômicos, ambientais e sociais componente fundamental para que haja eficácia nas relações com os stakeholders (partes interessadas), nas decisões sobre investimento e em outras relações de mercado. Para dar suporte a essa expectativa e para comunicar de forma clara e transparente o que se refira à sustentabilidade, é necessário compartilhar globalmente uma estrutura de conceitos, uma linguagem coerente e uma métrica. A missão da Global Reporting Initiative (GRI) é satisfazer essa necessidade, oferecendo uma estrutura confiável para a elaboração de relatórios de sustentabilidade, que possa ser usada por organizações de todos os tamanhos, setores e localidades. (GRI, 2006, p.2).
\end{abstract}

A GRI estabelece uma estrutura para os relatórios de sustentabilidade bem como diretrizes na elaboração desses. "A Estrutura de Relatórios da GRI visa servir como um modelo amplamente aceito para a elaboração de relatórios sobre o desempenho econômico, ambiental e social de uma organização.” (GRI, 2006, p.4.). As diretrizes estabelecidas pelo modelo GRI compreendem protocolos de indicadores, suplemento setorial e protocolos técnicos.

As Diretrizes para Elaboração de Relatórios de Sustentabilidade da GRI consistem de princípios para a definição do conteúdo do relatório e a garantia da qualidade das informações relatadas. Incluem também o conteúdo do relatório, composto de indicadores de desempenho e outros itens de divulgação, além de orientações sobre temas técnicos específicos relativos à elaboração do relatório. (GRI, 2006, p.4.).

O relatório GRI é composto por características da empresa e indicadores de desempenho, estes, por sua vez, divididos em indicadores essenciais e indicadores adicionais. São três grandes grupos de indicadores: econômicos, ambientais e sociais (Ilustração 5), totalizando 79 indicadores de desempenho com informações qualitativas e quantitativas da empresa. Os grandes grupos são mais uma vez divididos: econômico, ambiental, práticas trabalhistas e trabalho decente, direitos humanos, sociedade e responsabilidade pelo produto. Os indicadores devem atender aos padrões e requisitos estabelecidos no Conjunto de Protocolos de Indicadores (disponível em http://www.ethos.org.br/_Uniethos).

Após a finalização do relatório, é necessário, ainda, informar qual o nível de aplicação das Estruturas de Relatórios da GRI, ou seja, com que rigor as normas da GRI foram seguidas na 
elaboração de tal relatório de sustentabilidade. Foi criado um sistema de avaliação para definir o nível de aplicação por meio da atribuição de notas A, B ou C. A declaração do nível de aplicação da Estrutura de Relatórios da GRI busca estabelecer uma comunicação transparente e clara entre as organizações e seus usuários.

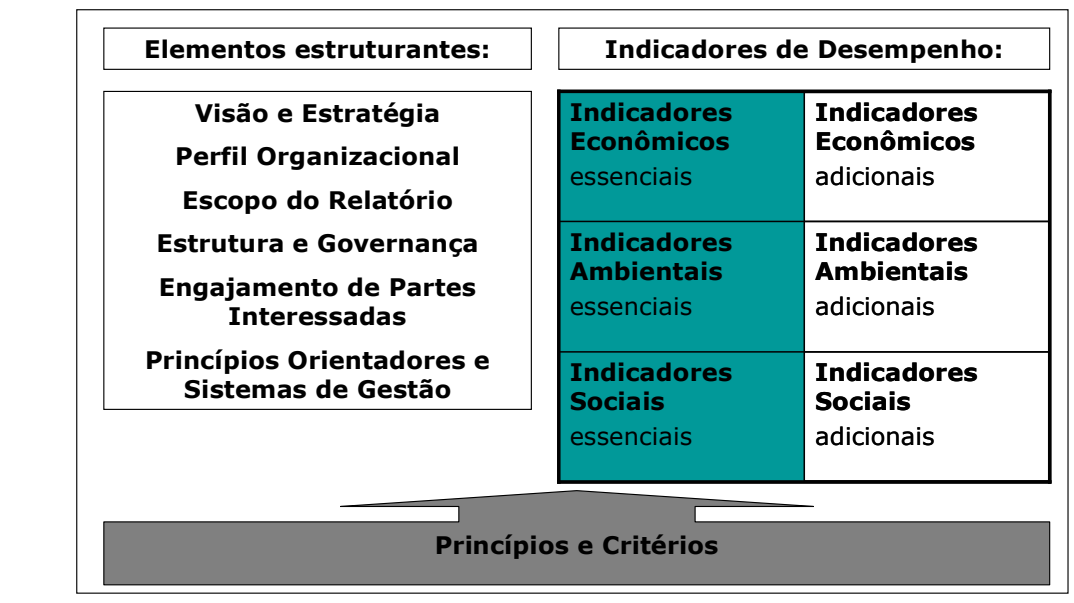

Ilustração 5 - Estrutura do relatório de sustentabilidade proposto pela GRI FONTE: Baseado em GRI (2006, p. 19-25)

No Brasil, o relatório GRI foi divulgado por um grupo de trabalho formado pelo Instituto Ethos, Aberje e Fundação Getúlio Vargas. A divulgação foi bastante intensa e atualmente diversas empresas brasileiras adotam este modelo. Ele tem a característica de não ter uma estrutura-padrão, mas sim um grupo de informações a serem divulgadas. Então, as empresas fazem seus Balanços Sociais com grande apelo mercadológico e no final colocam um índice remissivo direcionando para as páginas em que estão as informações solicitadas pelo GRI.

Entretanto, essa característica também dificulta a análise do relatório. As informações são pouco padronizadas devido ao grande número de indicadores descritivos e à falta de informações sobre as grandezas a serem utilizadas nas informações quantitativas (por exemplo, um indicador pede o número de empregados por faixas etárias, mas não diz quais os intervalos, então, as empresas definem intervalos diferentes, prejudicando a comparabilidade entre empresas e entre períodos).

O processo de desenvolvimento do relatório GRI significou uma oportunidade para diferentes grupos promoverem suas agendas se apropriando desses conceitos. Cada vez mais companhias têm adotado a metodologia GRI em todo o mundo para preparar seus relatórios de sustentabilidade, mas, ao mesmo tempo, o nível de compromisso com os pressupostos do 
desenvolvimento sustentável é baixo. Conseqüentemente, as diretrizes desenvolvidas pela GRI são usadas como uma ferramenta para legitimação das ações e decisões das empresas (MONEVA; ARCHEL; CORREA, 2006, p. 134).

Em uma comparação dos dois modelos citados, percebe-se que ambos pecam pelo excesso, um pelo excesso de objetividade e outro pelo excesso de subjetividade. O modelo Ibase tem como grande vantagem ser comparável e verificável, características que o modelo GRI tem em poucos dos 79 indicadores. Por outro lado, o modelo Ibase limita bastante o volume de informações fornecidas, ao contrário do modelo GRI que tem relatórios muito volumosos.

Com esse aumento da divulgação, a sociedade é quem ganha. Mas é importante que ela também faça seu papel. Cabe à sociedade cobrar a divulgação de informações e verificar, na medida do possível, as informações divulgadas. Apesar de o Balanço Social, em alguns casos, estar incluído no Relatório Anual da empresa, a informação não deve ficar restrita a administradores, contadores, economistas e profissionais afins. É importante que o maior número de profissionais se interesse por essas informações, assim, a cobrança sobre as empresas que ainda não divulgam este tipo de relatório aumenta, e a sociedade se beneficia com mais informações e mais empresas preocupadas com o desenvolvimento sustentável.

\footnotetext{
Da mesma forma que num passado próximo, os proprietários do capital sentiram necessidade de informações financeiras para decidir sobre o melhor investimento e que sofresse menor risco, surgindo, assim, as demonstrações contábeis na forma como são conhecidas hoje, surge agora a necessidade, não só de proprietários, mas também de empregados, governo, fornecedores e da comunidade como um todo, de informações que orientem a uma avaliação de desempenho baseada em conceitos que reúnem a preocupação com a responsabilidade social. (CUNHA, 2002, p. 44).
}

Enquanto a divulgação de informações socioambientais for voluntária, vale a teoria de Verrecchia (2001, p. 130) e serão divulgadas apenas as "boas notícias", isto é, aquelas com impacto positivo na avaliação da empresa. Por isso, foi um grande avanço para o Brasil a obrigatoriedade da Demonstração do Valor Adicionado, parte do Balanço Social que será abordada no próximo capítulo. 


\section{DEMONSTRAÇÃO DO VALOR ADICIONADO (DVA)}

A Demonstração do Valor Adicionado surgiu na década de 70 do século passado pela necessidade de publicar informações para os stakeholders da empresa. Em 1975, o Comitê Gestor dos Padrões Contábeis da Inglaterra - Accounting Standards Steering Committee (ASSC) - publicou um documento intitulado The Corporate Report que recomendava a publicação de uma demonstração que evidenciasse como os benefícios gerados pelo esforço de venda da empresa eram divididos entre empregados, provedores de capital, governo e reinvestimento (MEEK; GRAY, 1988, p. 73; HOPWOOD; BURCHELL; CLUBB, 1994, p. 211).

A estrutura da DVA apresenta duas partes com objetivos diferentes: uma parte mostra quanto a organização gera de riqueza, e a outra mostra como essa riqueza é distribuída entre os fatores de produção. O total de riqueza mostrado na primeira parte deve, necessariamente, ser igual ao total de riqueza distribuída da segunda parte. Essa igualdade vem da teoria econômica relacionada a valor adicionado.

\footnotetext{
No Brasil, os primeiros estudos dessa nova demonstração foram desenvolvidos no Departamento de Contabilidade e Atuária da Faculdade de Economia, Administração e Contabilidade da Universidade de São Paulo - FEA-USP. Nos últimos oito anos, a Demonstração do Valor Adicionado acabou tendo um aumento de vulto e importância. Sem medo de errar, pode-se afirmar que boa parte do impulso tomado por mais essa demonstração contábil foi sua inclusão no cálculo de excelência empresarial utilizado pela FIPECAFI - Fundação Instituto de Pesquisas Contábeis, Atuariais e Financeiras - para a escolha das empresas com os melhores desempenhos nos setores em que a atividade econômica é dividida para a edição de "Melhores e Maiores", da Revista Exame. [...] Claro que tal aumento não pode ser atribuído apenas a um único motivo; certamente o entendimento pelas empresas do tipo de informação de que poderiam passar a dispor, além do apoio dado pela CVM - Comissão de Valores Mobiliários, que passou a incentivá-las a divulgarem, de forma espontânea, esse tipo de demonstração, inclusive citando, textualmente o modelo divulgado pela FIPECAFI, são fatores que também muito contribuíram para esse comportamento. (SANTOS, 2005, p. 3).
}

Assim, este capítulo está dividido em quatro partes: a primeira faz uma contextualização do uso da DVA em outros países. A segunda parte trata da teoria econômica de valor adicionado e da igualdade entre produto, renda e consumo. A terceira parte mostra a estrutura da DVA e como são tratados atualmente os investimentos sociais realizados pelas empresas. Por fim, a última parte trata dos diferenciais e limitações da demonstração, conforme foram discutidos na literatura pesquisada. 


\subsection{Demonstração do Valor Adicionado em outros países}

Este tópico trata de estudos que abordam o surgimento da DVA e sua utilização em outros países. A intenção não é fazer uma lista exaustiva de países que utilizam ou já utilizaram a demonstração em estudo, mas traçar um panorama sobre sua criação e situação atual.

Apesar de referências anteriores serem encontradas na literatura contábil sobre valor adicionado (por exemplo, Suojanen, 1954, e Ball, 1968), foi após a publicação do The Corporate Report pela ASSC que emergiu a prática de divulgação da DVA. As primeiras DVAs foram divulgadas no Reino Unido em meados da década de 1970 (PONG; MITCHELL, 2005, p. 173).

No Reino Unido, a Demonstração do Valor Adicionado já teve ascensão e declínio. Conforme já mencionado, em 1975, a ASSC publicou o documento que recomendava, entre outras coisas, a demonstração de valor adicionado. Com isso, muitas empresas passaram a publicar a DVA. Entretanto, no final da década seguinte, diversas empresas deixaram de publicar a DVA (HOPWOOD, BURCHELL e CLUBB, 1994).

Burchell, Clubb e Hopwood (1985, p. 390-399) estudaram o contexto e as teorias sociais da contabilidade para o súbito interesse na DVA na década de 1970. Os autores delinearam três arenas para entender o movimento social por trás do processo de adoção da DVA no Reino Unido.

A primeira arena é definida pelo processo de padronização contábil. A publicação do The Corporate Report foi uma resposta da ASSC à ameaça de intervenção governamental ao processo de padronização contábil. A proposta de DVA colocada no relatório continha algumas inconsistências, e o ASSC encomendou quatro estudos sobre a demonstração às organizações parceiras.

Os relatórios apresentados por ambos, The Institute of Chartered Accountants in England and Wales (Renshall et al., 1979) e The Institute of Chartered Accountants in Scotland (Morley, 1978) concluíram em favor da demonstração de valor adicionado, mas adicionaram uma ressalva que a "padronização de práticas é condição necessária para qualquer exigência formal" (Renshall et al., 
1979, p. 38) e também "para conferir comparabilidade à Demonstração do Valor Adicionado e ainda resguardar a confiabilidade dos usuários da demonstração" (Morley, 1978, p. 141). O estudo preparado por The Institute of Cost and Management Accountants foi notavelmente menos entusiástico e apresentou o valor adicionado como apenas mais uma adição para a sacola de ferramentas gerenciais que poderia ser bem empregado em conexão com sistemas de remuneração dos empregados e relações públicas (Cox, 1979). A questão da padronização não foi levantada no relatório. $\mathrm{O}$ estudo da The Association of Certified Accountants investigou a necessidade de informações dos potenciais usuários da demonstração de valor adicionado e revisou as práticas corporativas anteriores na área discutindo políticas de mensuração e evidenciação (Gray \& Maunders, 1980). Foram identificadas duas abordagens para mensuração do valor adicionado e, embora o estudo tenha afirmado que "conceitualmente seria desejável que fosse adotada uma abordagem consistente de uma maneira ou da outra” (p. 28), ele também argumentou que a demonstração do valor adicionado deveria ser "colocada fora das restrições estabelecidas por convenção" com o intuito de facilitar seu "desenvolvimento imaginativo" de acordo com as necessidades da decisão dos potenciais usuários (p. 37). (BURCHELL; CLUBB; HOPWOOD, 1985 , p. 392, tradução livre) $)^{10}$.

A segunda arena é definida pela gestão macroeconômica. Durante o período de 1974 a 1979, o chamado Labour Government, foi marcado por proeminentes e recorrentes políticas de renda. Foram fixadas normas para aumento de salários, atrelando-o ao aumento de produtividade. Isso criou um importante papel para o valor adicionado que passa a compor os esquemas de remuneração dos empregados. Por conseguinte, a DVA passa a ser uma importante ferramenta de comunicação entre a empresa e seus colaboradores.

A terceira arena é definida pelas relações industriais e pela evidenciação de informações. A década de 1970 foi marcada por um período de "democracia industrial". Os sindicatos ficaram mais fortes e a relação empresa-empregados passou por uma redefinição na distribuição de poder. Com isso, sindicatos e empregados passam a exigir maior volume de informações, e o lucro assumiu uma conotação mais negativa. Nesse contexto, a DVA se ajustava melhor às necessidades de evidenciação dos resultados para a sociedade.

\footnotetext{
${ }^{10}$ The reports issued by both the Institute of Chartered Accountants in England and Wales (Renshall et al., 1979) and the Institute of Chartered Accountants in Scotland (Morley, 1978) conclude in favour of value added reporting but add the caveat that "Standardization of practice is a necessary precondition to any formal requirement" (Renshall et al., 1979, p. 38) so as "to bring comparability to Value Added Statements and so safeguard the confidence of readers in the Statement" (Morley, 1978, p. 141). The study prepared for the Institute of Cost and Management Accountants was notably less enthusiastic and presented value added as just one more addition to the kitbag of management tools which may be usefully employed in connection with employee payment systems and public relations (Cox, 1979). The issue of standardization was not raised in the report. The Association of Certified Accountants' study investigated the information needs of potential users of value added statements and reviewed existing corporate practice in the area before discussing measurement and disclosure policy (Gray \& Maunders, 1980). Two approaches to the measurement of value added were identified, and although it was stated that "conceptually it would seem desirable that a consistent approach be adopted one way or the other" (p. 28), it also was argued that value added reporting should be "placed outside the restrictions established by convention" in order to facilitate its "imaginative development" according to the decision requirements of its potential users (p. 37).
} 
Burchell, Clubb e Hopwood (1985) perceberam que a redução no interesse pela DVA coincidiu com a mudança do governo britânico em 1979 que gerou transformações no ASSC. Com isso, as três arenas discutidas foram repentinamente rompidas e transformadas. A política de governo mudou, as relações industriais passaram a ser conduzidas de outra maneira, e a possibilidade de intervenção do governo nas práticas contábeis tornou-se uma possibilidade remota. O ASSC mudou seu foco e acabou removendo o tema valor adicionado da agenda de discussões. A partir de então, as empresas pararam, descompassadamente, de publicar a DVA.

Pong e Mitchell (2005) também analisaram o "fenômeno" DVA no Reino Unido. Eles afirmam que Burchell, Clubb e Hopwood (1985) inovaram as pesquisas acadêmicas sobre o assunto porque incluíram a vertente social em suas análises, mas sua ênfase exclusiva às questões sociais levou-os a desconsiderar aspectos contábeis importantes, já que não é valorizado o conteúdo das informações trazidas pela DVA nem sua relação com as expectativas e necessidades dos usuários (p. 183).

O papel das três arenas referenciadas por Burchell, Clubb e Hopwood (1985) parece ter sido mais significante para descrever a DVA como produto do tempo e lugar na agenda daqueles que decidem sobre as evidenciações corporativas (decisão política) do que uma tentativa de conduzir uma mudança universal de fato (PONG; MITCHELL, 2005, p. 193).

Gray, Kouhy e Lavers (1995a, p. 61-67) relacionam o contexto político do Reino Unido nas décadas de 1970, 1980 e 1990 com os padrões de evidenciação social das companhias britânicas. Os autores definem o período como uma época de "re-empoderamento" do capital com o apoio do Estado, pois ocorre a transição para o Estado Mínimo, e o governo transfere para o mercado funções tradicionais relacionadas ao bem-estar da sociedade. Ainda segundo os autores, o governo aprovou leis que incentivavam a evidenciação de informações sobre o emprego de deficientes e estimulavam maior participação dos empregados nas decisões e na propriedade da empresa. O mercado "aceita" as responsabilidades adicionais e responde com maior envolvimento com a comunidade. Esses autores colocam a necessidade de uma nova roupagem para a relação empresa-sociedade no final desse período. O relatório anual reflete isso em ampla evidenciação de esquemas de distribuição de ações, consultas aos empregados, treinamento, oportunidades iguais e maior envolvimento com a comunidade, enquanto as 
antigas áreas de confronto do relatório - demonstração do valor adicionado e informações para os sindicatos - "silenciosamente desapareceram".

[...] entre 1979 e 1991, a totalidade do UK CSR [Relatório Social Corporativo no Reino Unido] aumentou em quatro vezes, evidenciações relacionadas aos empregados caíram de aproximadamente 90 por cento do total para cerca de 78 por cento, e informações sobre relação com a comunidade e meio ambiente aumentaram de aproximadamente 10 para 32 por cento do total do relatório. Informações relacionadas à relação com os clientes permaneceram em um nível muito baixo. A única área do CSR que caiu sistematicamente foi a evidenciação da demonstração do valor adicionado. (GRAY; KOUHY; LAVERS, 1995a, p. 62, tradução livre) ${ }^{11}$.

O conteúdo da DVA no Reino Unido não ofereceu a atratividade necessária para obter apoio nem daqueles que voluntariamente publicaram a DVA (administradores das empresas) nem daqueles que supostamente seriam os maiores interessados (outros empregados e suas representações sindicais). Essa ausência de apoio parece ter contribuído significativamente para o desaparecimento dessa demonstração (PONG; MITCHELL, 2005, p. 193).

As informações contidas na DVA não sugerem que esse era um mecanismo adequado para resolver as disputas de natureza trabalhista. Ao examinar a distribuição de valor adicionado para empregados, geralmente, esse parecia ser o grupo de stakeholder mais favorecido da empresa. Isso em nada ajudaria em negociações sindicais e ainda poderia ter um reflexo ruim para a administração na avaliação dos acionistas. Então, a evidenciação da distribuição do valor adicionado não seria necessariamente uma estratégia para estimular a cooperação entre os stakeholders, ao contrário, seria uma propensão para fomentar conflitos de interesses entre eles, pois além de conhecer as participações relativas no valor adicionado, ainda seria possível perceber a mudança nessas proporções ao longo do tempo (PONG; MITCHELL, 2005, p. 193-194).

Haller e Stolowy (1998) fizeram um estudo comparativo entre França e Alemanha. O objetivo do trabalho era comparar o papel da informação "valor adicionado" nos relatórios e análises contábeis desses países. Eles analisaram os relatórios anuais de 1993 das 100 maiores empresas de cada país. O estudo concluiu que as empresas são relutantes em evidenciar informação de valor adicionado, ou mesmo a demonstração do valor adicionado, de modo a

\footnotetext{
${ }^{11}$ [...] between 1979 and 1991, total UK CSR [Corporate Social Reporting] rose by over four times, employeerelated disclosure fell from approximately 90 per cent of total to about 78 per cent, and community and environmental reporting rose from approximately 10 per cent to 32 per cent of total disclosure. Customer-related disclosure remained at a very low level. The only area of CSR which fell systematically was the disclosure of the value added statement.
} 
ser comparável com outras empresas. Os autores mostram-se surpresos e afirmam que o resultado é espantoso porque Alemanha e França são internacionalmente consideradas como países em que o conceito de valor adicionado tem um papel considerável na contabilidade financeira.

Meek e Gray (1988) estudaram a utilidade da DVA para as companhias norte-americanas e propõem que o uso dessa demonstração como informação suplementar poderia evidenciar implicações mais amplas da atividade corporativa. Eles também avaliaram a adequação da DVA aos padrões contábeis americanos (Statement of Financial Accounting Concepts SFAC) e relataram a adequação ao SFAC $n^{\circ}$. 2, cujo conteúdo traz a necessidade das informações contábeis serem relevantes, confiáveis e compreensíveis ao usuário, e ao SFAC $n^{0} .5$ que traz a necessidade das informações contábeis serem articuladas entre si. Os autores colocaram ainda a questão da auditoria da Demonstração do Valor Adicionado: justamente pela adequação aos SFACs, não haverá novos problemas para os auditores nem aumentará o potencial de reclamações de negligência contra eles.

Evraert e Riahi-Belkaoui (1998) também estudaram a utilidade do valor adicionado e afirmam que o custo de publicar a DVA pode ser imaterial dada a disponibilidade de todas as informações que a compõem. E ainda que, dado o baixo custo relativo aos benefícios potencialmente muito maiores mostrados em seu artigo, emitir relatórios de valor adicionado ou evidenciar os dados necessários para calcular o valor adicionado parece ser uma melhoria ao atual sistema de publicação americano.

Diversos estudos empíricos comparando valor adicionado, fluxo de caixa e lucro foram conduzidos com empresas norte-americanas. Bao e Bao (1989), Karpik e Riahi-Belkaoui (1989), Bannister e Riahi-Belkaoui (1991), Riahi-Belkaoui (1993), Riahi-Belkaoui e Fekrat (1994), Riahi-Belkaoui e Picur (1994), Bao e Bao (1996), Riahi-Belkaoui (1997), Bao e Bao (1998) e Riahi-Belkaoui (1999) realizaram estudos sem a publicação da DVA, isto é, os trabalhos calcularam o valor adicionado com base nas remunerações dos fatores de produção (salários, dividendos, juros, aluguéis, impostos e lucros retidos). Apesar das limitações dos estudos (esses estudos serão mais detalhados no tópico 2.4), a maior parte deles conclui que há superioridade na qualidade da informação de valor adicionado em relação ao lucro e ao fluxo de caixa. 
Apesar dos estudos de Meek e Gray (1988), da recomendação da American Accounting Association (1990) e dos estudos empíricos relacionados, Picur (2007), após um intervalo de quase vinte anos, mostra a baixa relevância nos EUA da divulgação de informações de valor adicionado até aquela data.

A África do Sul é o único país que se equipara ao Brasil atualmente com relação à divulgação da DVA. Em 1998, aproximadamente metade das companhias listadas na Bolsa de Valores de Joanesburgo publicava a DVA, voluntariamente, como parte integrante das demonstrações financeiras, e esta proporção vinha crescendo de maneira sustentável (VAN STADEN, 1998, p. 44; VAN STADEN, 2003, p. 225). Esse país incentiva a publicação da demonstração e há diversos estudos acadêmicos sobre a DVA.

Van Staden (2000, p. 5) pesquisou junto a uma amostra de 94 empresas sul-africanas as cinco principais razões pelas quais elas publicavam a DVA. São elas, em ordem de importância:

1. para ser usada como forma de comunicação com os empregados;

2. para ganhar pontos na premiação anual para relatórios financeiros;

3. para indicar responsabilidade social por parte da companhia;

4. para facilitar negociações salariais e acordos coletivos e

5. para condicionar as expectativas dos empregados.

Van Staden questiona a utilidade da DVA em dois artigos (1998 e 2003). Em 1998, na África do Sul, concluiu que mais de $50 \%$ dos usuários da contabilidade entrevistados não pretendiam usar a DVA para obter informações. Em 2003 concluiu que o alto nível de publicação da DVA na África do Sul, apesar de não ser útil aos usuários como concluiu anteriormente, é suportado pela Teoria da Legitimidade e pela Teoria da Economia Política da Contabilidade. O autor mostra a importância da DVA, mas critica a informação fornecida por ela, pois, por muitas vezes, a DVA não ser auditada como as demais demonstrações financeiras, as companhias podem fornecer apenas as "boas notícias", omitindo as más, o que torna a informação não confiável.

Oliveira (2008) pesquisou uma amostra de 50 países (PIB total da amostra era US\$ 38,2 trilhões de dólares no ano 2006) que adotam ou permitem as normas internacionais elaboradas pelo IASB com o objetivo de verificar se existe divulgação da DVA. Foram observadas 10 empresas de capital aberto por país. A DVA foi encontrada em 19 dos 50 países, e apenas 
13\% das empresas analisadas divulgaram a demonstração. Das empresas que publicaram a demonstração, $76 \%$ o fizeram no relatório anual e $24 \%$, no Relatório Social. A Tabela 3 mostra um resumo dos países em que foram encontradas DVAs.

Tabela 3 - Número de DVAs encontradas por tipo de apresentação

\begin{tabular}{l|r|c|c|c|c}
\hline Países & $\begin{array}{c}\text { PIB 2006 } \\
\text { (em US\$ } \\
\text { milhões) }\end{array}$ & $\begin{array}{c}\text { Relatório } \\
\text { Anual }\end{array}$ & $\begin{array}{c}\text { Relatório de } \\
\text { Sustentabilidade }\end{array}$ & Forma Gráfica & Total de DVA \\
\hline África do Sul & 257.894 & 6 & 1 & - & 7 \\
Alemanha & 2.914 .988 & - & - & - & 1 \\
Áustria & 323.071 & - & - & - & 1 \\
Botsuana & 11.298 & 3 & - & - & 3 \\
Brasil & 1.089 .301 & 8 & - & 2 & 8 \\
França & 2.271 .280 & - & - & - & 2 \\
Ilhas Maurício & 6.317 & 3 & - & - & 3 \\
Índia & 874.771 & 1 & 2 & - & 1 \\
Inglaterra & 2.435 .699 & - & 1 & - & 2 \\
Irlanda & 222.609 & - & - & 1 & 1 \\
Malta & 6.442 & - & - & - & 1 \\
Nepal & 9.034 & 1 & 1 & - & 1 \\
Peru & 92.306 & - & 1 & - & 1 \\
Portugal & 195.186 & - & - & - & 1 \\
Sri Lanka & 28.280 & 7 & - & - & 7 \\
Tanzânia & 14.351 & 2 & $\mathbf{8}$ & $\mathbf{4}$ & $\mathbf{4 2}$ \\
Total & $\mathbf{1 0 . 7 5 2 . 8 2 7}$ & $\mathbf{3 2}$ & & & \\
\hline
\end{tabular}

FONTE: OLIVEIRA; 2008, p. 45, adaptado ${ }^{12}$.

Percebe-se, com essa revisão da literatura internacional, que, atualmente, a prática de evidenciar a demonstração de valor adicionado não é comum. Entretanto, é interessante perceber que vários desses autores, ainda que a prática não corresponda às expectativas de seus trabalhos, defendem a divulgação das informações de valor adicionado e enfatizam a qualidade e a utilidade dessa informação para a sociedade.

Com isso, o Brasil tem um diferencial por impor a divulgação da DVA às companhias de capital aberto. Muitas pesquisas deverão se realizar doravante para comprovar as vantagens e desvantagens da publicação da DVA. É válido notar, conforme colocado no estudo de Burchell, Clubb e Hopwood (1985), que o contexto social é importante para entender a divulgação da demonstração no país. Assim, devem ser evitados estudos futuros que sejam apenas replicações de estudos internacionais e não considerem o contexto brasileiro.

\footnotetext{
${ }^{12}$ Foi incluída a coluna com o Produto Interno Bruto de cada país, informação que não constava no texto original. Os relatórios analisados pela autora se referiam ao ano 2006, e os valores de PIB coletados referem-se ao mesmo período. As informações foram obtidas no site do Fundo Monetário Internacional acessado em 05/09/09 (http://www.imf.org/external/pubs/ft/weo/2009/01/weodata/weoselgr.aspx).
} 


\subsection{Valor Adicionado}

A macroeconomia estuda os mercados em conjunto, isto é, estuda os mercados de modo agregado. É a área da economia responsável por mensurar a atividade econômica de um país. A Contabilidade Nacional é o instrumento utilizado para realizar essa mensuração e o faz por meio do princípio contábil das partidas dobradas. Entre os conceitos básicos a partir dos quais é desenvolvida a Contabilidade Nacional, estão os conceitos de produto e renda.

A produção é a principal atividade econômica a ser medida, uma vez que refletirá a capacidade de satisfação das necessidades dos membros da sociedade. Assim, o primeiro passo para avaliar-se o desempenho de um país é medir o seu produto. Este corresponde a soma daquilo que foi produzido em um país durante determinado período de tempo. [...] A partir do produto, podemos avaliar o crescimento econômico de um país. (GREMAUD; VASCONCELLOS; TONETO JÚNIOR, 2002, p. 50).

A produção de um país envolve produtos e serviços para serem consumidos pela sociedade (consumo final) ou utilizados na produção de outros bens e serviços (consumo intermediário). Assim, para evitar o problema da dupla contagem, o produto do país inclui apenas os bens e serviços destinados ao consumo final ou utiliza o conceito de valor adicionado. $\mathrm{O}$ valor adicionado em determinada etapa de produção é "a diferença entre o valor bruto produzido nessa etapa (igual a vendas mais acréscimo de estoques) e os consumos intermediários" (SIMONSEN; CYSNE, 2007, p.147).

O cálculo do produto nacional por meio da soma dos produtos e serviços finais obterá o mesmo valor do cálculo pela soma dos valores adicionados em todas as etapas da produção. Para explicar o conceito de valor adicionado, Yoshioca (1998, p. 3) apresenta o exemplo exposto na Tabela 4.

Tabela 4 - Exemplo de valor adicionado ao longo da cadeia produtiva

\begin{tabular}{lcccc}
\hline \multicolumn{1}{c|}{ Estágio da Produção } & Vendas & Aquisições & Valor Adicionado \\
\hline Proprietário de terras (vende árvores) & 50 & 0 & 50 \\
Proprietário de madeira & 100 & 50 & 50 \\
Produtor de mobília & 200 & 100 & 100 \\
Varejista (vende mobília) & 250 & 200 & 50 \\
\hline Soma & 600 & 350 & 250 \\
\hline
\end{tabular}

FONTE: YOSHIOCA; 1998, p.3. 
O exemplo estuda o processo produtivo de um móvel. O processo todo gerou riqueza econômica de \$250, mas é possível identificar a parcela gerada por cada etapa do processo. A produção se inicia no cultivo da árvore que fornece a madeira e termina com a venda da mobília, no varejo, para um consumidor final. Percebe-se que, em cada etapa da produção, existe um acréscimo de valor. Nota-se ainda a igualdade entre a soma dos valores adicionados em todas as etapas e o valor das vendas na última etapa da cadeia produtiva.

A adição de valor justifica-se pela necessidade de custear os esforços de produção ou venda envolvidos em cada etapa. Supondo a produção de mobília extremamente artesanal, sem utilizar nenhum outro recurso além da madeira, ainda será necessário um esforço de transformação da madeira em mobília, isto é, será necessário trabalho, que deve ser remunerado, por isso a mobília tem maior valor que a madeira: existe adição de valor. Portanto, uma empresa gera mais riqueza quanto maior o valor que consegue adicionar aos seus produtos.

A produção envolve matéria-prima (bens e serviços de consumo intermediário) e fatores de produção. São considerados fatores de produção: terra, capital e trabalho (GREMAUD; TONETO JR., 2007, p. 202). Ainda no caso do produtor de mobília, suponha que a empresa depende apenas do capital investido pelo proprietário e do trabalho do artesão responsável por transformar a madeira em mobília. Como no exemplo de Yoshioca (1998), o valor adicionado pelo produtor de mobília foi $\$ 100$, capital e trabalho devem ser remunerados com essa quantia total. Mas qual a proporção da distribuição entre os fatores de produção? O proprietário pode ficar com $90 \%$ e pagar apenas $\$ 10$ para o artesão, ou pode dividir meio a meio, depende do acordo realizado entre as partes.

Tem-se, então, o conceito de renda: remuneração dos fatores de produção. Salários, juros, lucros e aluguéis remuneram, respectivamente, trabalho, capital de empréstimo, capital de risco e propriedade física de bens de capital. Para evitar a dupla contagem, são considerados na Contabilidade Nacional apenas juros e aluguéis pagos a pessoas físicas, pois quando pagos a pessoas jurídicas, tais valores são contabilizados nos lucros das empresas (SIMONSEN; CYSNE, 2007, p. 147).

Por conseguinte, o produto nacional pode ser mensurado pela ótica do produto ou pela ótica da renda (e ainda pela ótica do consumo). "A igualdade entre produto e renda decorre do fato 
de que o valor adicionado em cada etapa produtiva corresponde justamente à remuneração dos fatores envolvidos naquela etapa" (GREMAUD; TONETO JR., 2007, p. 205).

A Ilustração 6 mostra o fluxo circular da atividade econômica de uma sociedade. Paulani e Braga (2007, p. 21) explicam que as linhas contínuas representam o fluxo de bens e serviços e as linhas pontilhadas representam o fluxo monetário e ainda explicam a numeração da figura:

1. as famílias cedem às empresas os fatores de produção de que são proprietárias e, em troca, recebem das empresas uma renda, ou seja, uma remuneração sob a forma de dinheiro;

2. as empresas combinam esses fatores num processo denominado processo de produção e obtêm, como resultado, um conjunto de bens e serviços;

3. com a renda recebida em troca da utilização, na produção, dos fatores de que são proprietárias, as famílias compram das empresas os bens e serviços por estas produzidos;

4. as famílias consomem os bens e serviços.

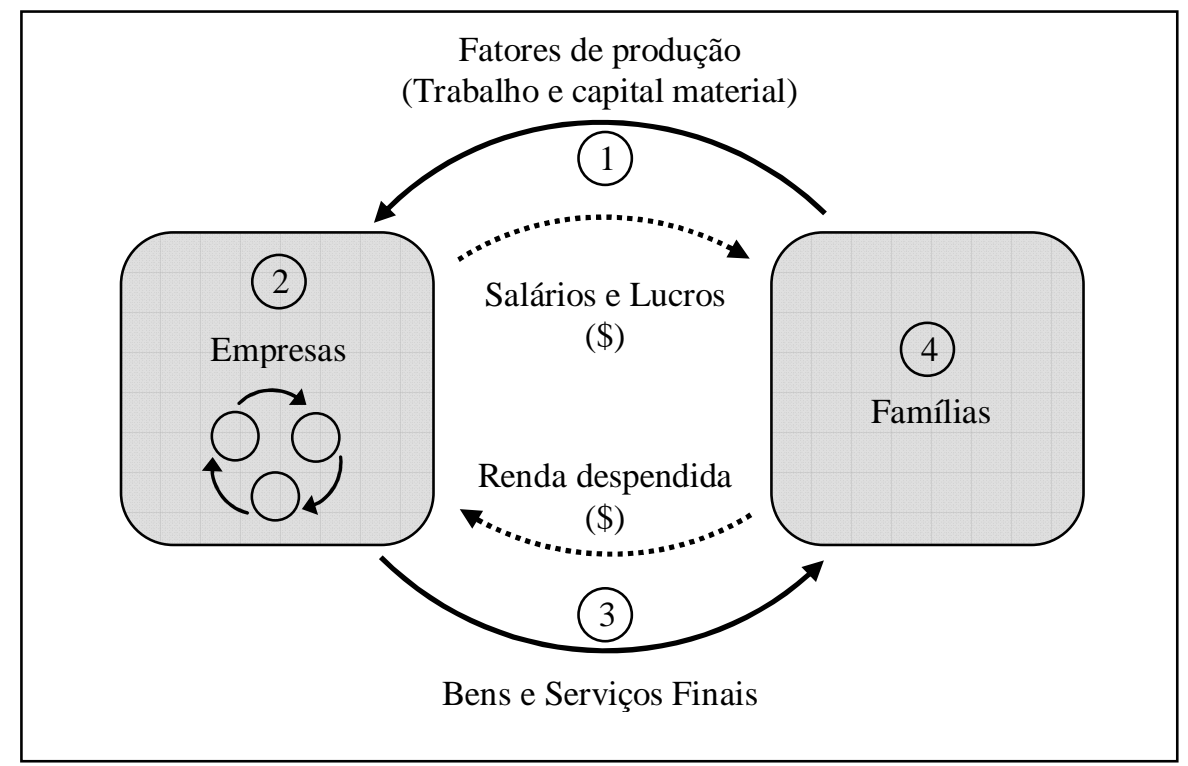

Ilustração 6 - Fluxograma empresas-famílias FONTE: PAULANI; BRAGA, 2007, p. 21.

O esquema básico apresentado ainda não inclui investimentos, depreciação, a participação do governo e as transações com outros países, importações e exportações. Esses fatores são indispensáveis no cálculo do produto nacional e serão mais bem explicados no capítulo 5 .

O conceito de valor adicionado usado na elaboração da DVA é o conceito econômico apresentado. Se todas as entidades produtivas do país elaborassem essa demonstração, a soma da riqueza gerada seria o produto nacional. Entretanto existem diferenças metodológicas no cálculo do valor adicionado pelo IBGE e no cálculo da DVA. Isto é, a metodologia contábil de cálculo do valor adicionado apresenta algumas diferenças da metodologia econômica. 
De Luca (1996) faz uma conciliação das duas metodologias e apresenta todas as diferenças. Apesar da alteração no modelo de cálculo do PIB pelo IBGE em 2000, quando foi incorporada a estrutura de matriz insumo-produto recomendada pela ONU, os conceitos por trás da metodologia mantiveram-se os mesmos. Portanto, o trabalho de De Luca manteve-se válido também.

\begin{abstract}
A base de mensuração é um dos principais pontos a ser conciliado. $\mathrm{O}$ conceito de valor adicionado utilizado na economia adota o conceito de produção. Em geral, a Demonstração do Valor Adicionado apresenta o valor adicionado em função das suas vendas. Para conciliar, a própria contabilidade da empresa pode dar as informações necessárias para o cálculo do valor adicionado a partir do valor da produção.

Outros itens tais como a produção distribuída gratuitamente, as participações dos empregados nos lucros, juros nominais e receita e despesa de aluguel, também merecem atenção especial pois têm tratamentos diferenciados. Merecem atenção ainda, os itens como por exemplo, a provisão para devedores duvidosos, que é registrada pela Demonstração do Valor Adicionado e não possui orientação específica por parte do IBGE no sistema de contas nacionais brasileiro. (DE LUCA, 1996, p. 147).
\end{abstract}

A Demonstração do Valor Adicionado pode ser resumida na equação apresentada por Morley (1979, p. 619):

$$
S-B-D e p=W+I+D i v+T+R
$$

onde:

$\mathrm{S}=\mathrm{Vendas}$

$\mathrm{B}=$ Aquisição de materiais e serviços

Dep $=$ Depreciação

$\mathrm{W}=$ Salários

$\mathrm{I}=\mathrm{Juros}$

Div $=$ Dividendos

$\mathrm{T}=$ Tributos

$\mathrm{R}=$ Lucros retidos

O lado esquerdo da equação mostra a formação do valor adicionado, e o lado direito mostra como o valor adicionado foi distribuído entre os stakeholders. A equação (1) expressa a distribuição do valor adicionado líquido, como é utilizado no Brasil. Também existe DVA que apresenta a Depreciação (Dep) como distribuição de valor, conforme equação (2). Neste caso, o lado esquerdo mostra o valor adicionado bruto e o lado direito, sua distribuição. A questão da depreciação será discutida no item 2.3 deste capítulo.

$$
S-B=W+I+D i v+T+R+D e p
$$


Devido à identidade macroeconômica entre produto e renda, a formação do valor adicionado pode ser calculada pelo método aditivo ou pelo método subtrativo. Nas equações apresentadas, o método aditivo é exposto do lado direito (soma da remuneração dos fatores de produção), e o método subtrativo é exposto do lado esquerdo (diferença entre vendas e aquisição de materiais e serviços de terceiros). A possibilidade de calcular o valor adicionado pelo método aditivo viabilizou o estudo da DVA em países que não têm como prática a elaboração e divulgação dessa demonstração, como os EUA (veja os trabalhos de RiahiBelkaoui, por exemplo).

Com isso, explica-se a igualdade das duas partes da DVA: formação do valor adicionado e distribuição do valor adicionado. A seguir, será discutida a estrutura da DVA com foco nos pontos mais divergentes com relação às demonstrações expostas em outros países.

\subsection{Estrutura da Demonstração do Valor Adicionado}

A Demonstração do Valor Adicionado foi regulamentada recentemente no Brasil com o Pronunciamento Técnico CPC n. ${ }^{\circ} 09$ aprovado pela CVM com a Deliberação n. ${ }^{\circ}$ 557/08. Até então, as empresas que publicavam DVA o faziam pelo modelo FIPECAFI ou pelo modelo do Conselho Federal de Contabilidade (CFC). Como o estudo empírico desta tese utiliza relatórios referentes a 2007, este tópico analisa a estrutura da DVA conforme os modelos usados na época. Para conhecimento, o modelo de DVA do CPC está exposto no Anexo E.

A CVM, em seu OFÍCIO-CIRCULAR/CVM/SNC/SEP n ${ }^{\circ}$. 01/2006 emitido em fevereiro de 2006, incentivava a divulgação voluntária da DVA e sugeria a utilização do modelo FIPECAFI:

Dentro dessa visão, a CVM vem incentivando e apoiando a divulgação voluntária de informações de natureza social, tendo, inclusive, já em 1992, apoiado e estimulado a divulgação da DVA, por meio do Parecer de Orientação CVM no. 24/92. No Ofício Circular CVM/SNC/SEP/ no 01/00, a CVM sugeriu a utilização de modelo elaborado pela Fundação Instituto de Pesquisa Contábeis, Atuariais e Financeiras da USP (FIPECAFI). Além disso, fez incluir no anteprojeto de reformulação da Lei $\mathrm{n}^{\circ}$. 6.404/76 a obrigatoriedade da divulgação da Demonstração do Valor Adicionado e de informações de natureza social e de produtividade.

Considerando que as companhias abertas vêm, cada vez mais, aderindo à divulgação de informações de natureza social, principalmente a DVA, e, dentro desse caráter voluntário de divulgação, objetivando orientar e incentivar aquelas empresas que ainda não aderiram, estamos 
apresentando um modelo simplificado de Demonstração do Valor Adicionado (baseado em modelo elaborado pela FIPECAFI) com instruções para o seu preenchimento.

O modelo FIPECAFI não era o único modelo de DVA em uso no Brasil em 2007. Entre os demais estava o modelo do Conselho Federal de Contabilidade (CFC), aprovado pela Resolução $\mathrm{n}^{0}$. 1.010/05. A norma brasileira de contabilidade (NBC T 3.7/2005), aprovada por essa Resolução, trazia um modelo muito semelhante ao modelo FIPECAFI. O Quadro 5 mostra a estrutura das contas no modelo CFC em comparação ao modelo FIPECAFI.

Quadro 5 - Modelo FIPECAFI x Modelo CFC de DVA

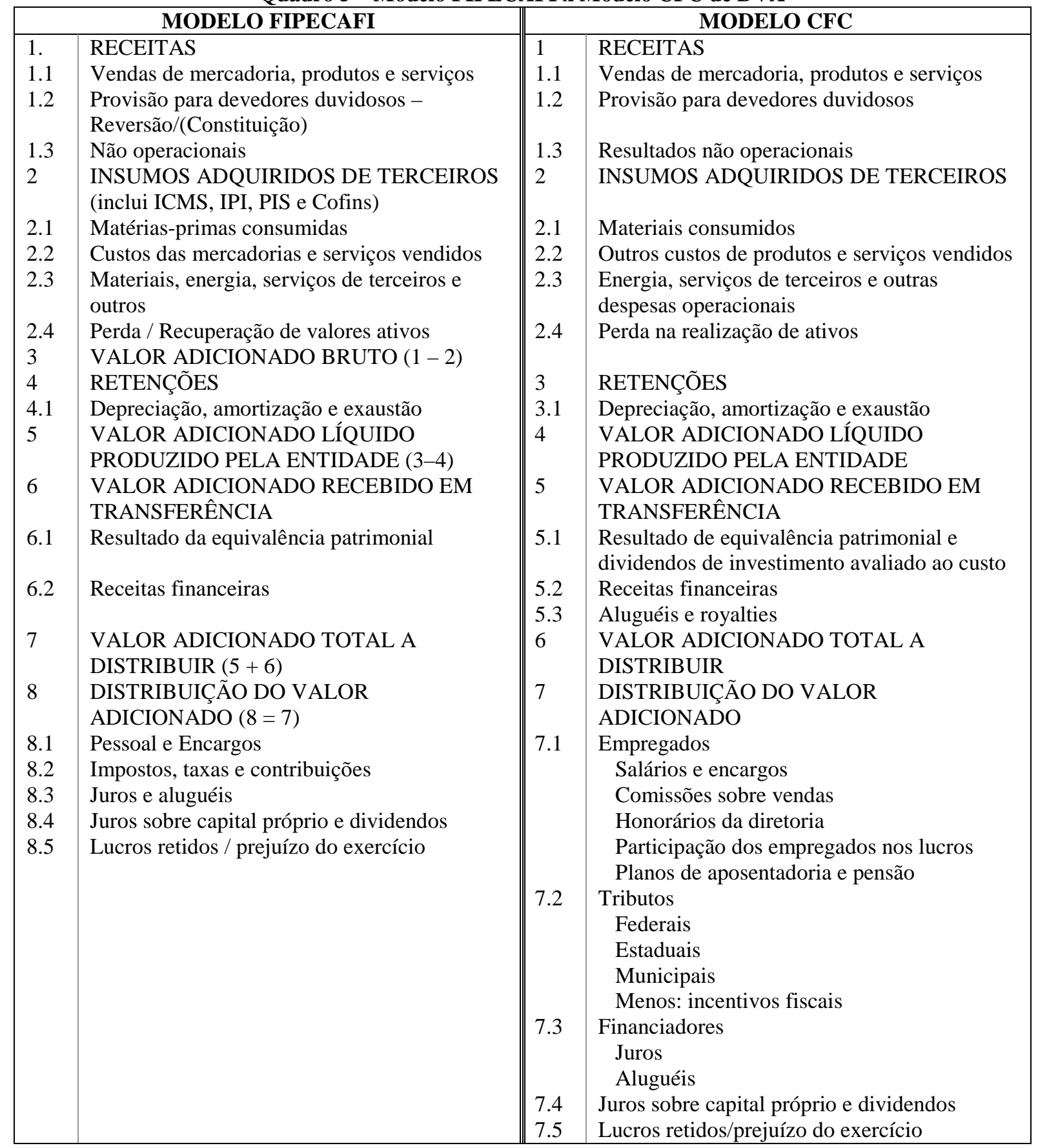


Além da estrutura semelhante, os dois modelos determinam o uso do regime de competência e a evidenciação de forma comparativa dos exercícios corrente e anterior, como nas demais demonstrações contábeis. A Resolução CFC n ${ }^{0}$. 1.010/05 determina ainda:

$[\ldots]$

3.7.1.4. Caso a entidade elabore Demonstrações Contábeis Consolidadas, a Demonstração do Valor Adicionado deve ser elaborada com base nas demonstrações consolidadas, e não pelo somatório das Demonstrações do Valor Adicionado individuais. (CFC, p.1)

$[\ldots]$

3.7.3.2. A Demonstração do Valor Adicionado deve ser consistente com a demonstração do resultado e conciliada em registros auxiliares mantidos pela entidade.

3.7.3.3. A Demonstração do Valor Adicionado deve conter representação percentual participativa.

3.7.3.4. As informações contábeis contidas na Demonstração do Valor Adicionado são de responsabilidade técnica de contabilista registrado no Conselho Regional de Contabilidade.

3.7.3.5. A Demonstração do Valor Adicionado deve ser objeto de revisão ou auditoria se a entidade possuir auditores externos independentes que revisem ou auditem suas Demonstrações Contábeis. (CFC, p.4).

Vale ressaltar que Santos (2003, p. 43) traz também um modelo de DVA específico para bancos que não será abordado neste trabalho. Os subtópicos a seguir tratam do conteúdo de cada grupo da DVA, abordando as instruções da FIPECAFI (SANTOS, 2003, FIPECAFI, 2007 e CVM, 2006) e do CFC (CFC, 2005).

\subsubsection{Receitas}

O item de receitas representa o total das receitas geradas pela empresa deduzido da provisão para perdas por vendas a prazo. Os conceitos do modelo FIPECAFI e do modelo CFC são muito semelhantes.

1 - RECEITAS (soma dos itens 1.1 a 1.3 )

1.1 - Vendas de mercadorias, produtos e serviços

Inclui os valores do ICMS e IPI incidentes sobre essas receitas, ou seja, corresponde à receita bruta ou faturamento bruto.

1.2 - Provisão para devedores duvidosos - Reversão/Constituição

Inclui os valores relativos à constituição/baixa de provisão para devedores duvidosos.

1.3 - Não operacionais

Inclui valores considerados fora das atividades principais da empresa, tais como: ganhos ou perdas na baixa de imobilizados, ganhos ou perdas na baixa de investimentos etc.

(FIPECAFI, 2007, p. 502).

3.7.2.4. No grupo de receita bruta e outras receitas, devem ser apresentados:

a) as vendas de mercadorias, produtos e serviços, incluindo os valores dos tributos incidentes sobre essas receitas, ou seja, o valor correspondente à receita bruta, deduzidas as devoluções, os abatimentos incondicionais e os cancelamentos; 
b) as outras receitas decorrentes das atividades afins não-constantes da letra "a" deste item, acima, ou não constantes do item 3.7.2.8, a seguir [valores adicionados recebidos em transferência];

c) os valores relativos à constituição (reversão) de provisão para créditos duvidosos;

d) os resultados não-decorrentes das atividades-fim, como: ganhos ou perdas na baixa de imobilizado, investimentos, etc., exceto os decorrentes do item 3.7.2.8 a seguir. (CFC, 2005, p.2).

Deve ser tratada neste item uma diferença entre o conceito econômico e o conceito contábil de valor adicionado. Conforme já colocado, a principal diferença entre os dois conceitos está na base de mensuração. A CVM defende o uso da mensuração por vendas pela simplicidade e pela possibilidade de conciliação com a Demonstração do Resultado do Exercício (DRE).

Pode-se verificar, no modelo abaixo [modelo FIPECAFI de DVA], a utilização do critério de cálculo do valor adicionado com base nas vendas, o que torna mais simples a elaboração da DVA e mais fácil seu entendimento, uma vez que, assim, o valor adicionado fica relacionado com os princípios contábeis utilizados nas demonstrações contábeis tradicionais, possibilitando sua conciliação com a demonstração do resultado. Parte-se, desse modo, das receitas brutas e subtraise o valor dos bens adquiridos de terceiros que foi incorporado ao produto final alienado ou serviço prestado, para que se conheça o valor efetivamente gerado pela companhia. Deve-se destacar, ainda, que a depreciação de ativos avaliados pelo custo de aquisição deve ser subtraída do valor adicionado bruto para se calcular o valor adicionado líquido, não devendo ser classificados tais valores como retenções do lucro do período. (CVM, 2006).

No cálculo do PIB pelo IBGE, não são computadas as vendas do país, mas sua produção. Assim, o 'valor adicionado total a distribuir' evidenciado na DVA não será exatamente igual ao valor adicionado calculado pela economia que compõe o PIB do país. A diferença entre os dois métodos está nos valores de estoques iniciais e finais (isto é, se não houver estoques iniciais nem finais, os valores adicionados serão iguais pelas duas metodologias).

O conceito de valor adicionado utilizado na economia adota o conceito de produção. Em geral, a Demonstração do Valor Adicionado apresenta o valor adicionado da empresa em função das suas vendas. Para conciliar, a própria contabilidade da empresa pode dar as informações necessárias para o cálculo do valor adicionado a partir do valor da produção. (DE LUCA, 1996, p. 147).

Isso mostra que a opção de usar as vendas não é uma questão de facilidade, mas uma questão de conceito. É o processo produtivo que agrega valor ao produto ou serviço, mas se a venda não ocorrer o valor adicionado não se realiza. Quando acontece a perda do estoque pode haver remuneração do trabalho, mas o capital, ao menos o capital próprio, acaba não recebendo a remuneração, e isso prejudica a economia. 


\subsubsection{Insumos adquiridos de terceiros}

Os insumos adquiridos de terceiros podem ser traduzidos como sacrifício, além dos fatores de produção capital e trabalho, necessário para a geração de receita. Assim, é classificada neste grupo a maioria das despesas e dos custos das mercadorias vendidas.

Duas considerações importantes devem ser ressaltadas: a questão dos impostos, tratada na explicação dos modelos FIPECAFI e CFC a seguir, e a questão dos custos das mercadorias não vendidas. Esta última questão é consequência da diferença de base de mensuração do valor adicionado, produção e vendas, citada no item anterior. Como a contabilidade respeita o regime de competência e considera a receita por sua realização, o custo incorrido na produção de mercadorias ainda não vendidas fica acumulado no estoque e, portanto, não compõe o item de insumos adquiridos de terceiros (nem a distribuição de valor adicionado pela mão de obra empregada na produção).

2 - INSUMOS ADQUIRIDOS DE TERCEIROS (soma dos itens 2.1 a 2.4)

2.1 - Matérias-primas consumidas (incluídas no custo do produto vendido).

2.2 - Custos das mercadorias e serviços vendidos (não inclui gastos com pessoal próprio).

2.3 - Materiais, energia, serviços de terceiros e outros (inclui valores relativos às aquisições e pagamentos a terceiros).

Nos valores dos custos dos produtos e mercadorias vendidos, materiais, serviços, energia, etc. consumidos deverão ser considerados os impostos (ICMS e IPI) incluídos no momento das compras, recuperáveis ou não.

2.4 - Perda/Recuperação de valores ativos

Inclui valores relativos a valor de mercado de estoques e investimentos, etc. (se no período o valor líquido for positivo deverá ser somado). (FIPECAFI, 2007, p. 502).

3.7.2.5. No grupo de insumos adquiridos de terceiros, devem ser apresentados:

a) materiais consumidos incluídos no custo dos produtos, mercadorias e serviços vendidos;

b) demais custos dos produtos, mercadorias e serviços vendidos, exceto gastos com pessoal próprio e depreciações, amortizações e exaustões;

c) despesas operacionais incorridas com terceiros, tais como: materiais de consumo, telefone, água, serviços de terceiros, energia;

d) valores relativos a perdas de ativos, como perdas na realização de estoques ou investimentos, etc.

3.7.2.6. Nos valores constantes dos itens "a", "b" e "c" acima, devem ser considerados todos os tributos incluídos na aquisição, recuperáveis ou não. (CFC, 2005, p. 2).

A diferença entre receitas e insumos adquiridos de terceiros é o Valor Adicionado Bruto, item 3, apresentado nos modelo FIPECAFI e CFC. O conceito de valor adicionado bruto é mais próximo do PIB. Pois, também no conceito econômico, a diferença entre o PIB e o PIL (Produto Interno Líquido) é a depreciação, isso é, "parcela dos bens de capital que é consumida a cada período" (GREMAUD; TONETO JÚNIOR, 2007, p. 207-208). 


\subsubsection{Retenções}

São consideradas retenções as despesas do período com depreciação, amortização e exaustão que representam o custo dos ativos imobilizados (respectivamente, bens físicos, direitos adquiridos e recursos minerais ou florestais) por seu uso no decorrer da vida útil econômica (FIPECAFI, 2007, p. 221).

Em outros países, a DVA apresenta depreciação, amortização e exaustão como lucro retido, ou seja, como uma forma de distribuição de valor adicionado. De fato, essa é uma questão polêmica sobre a estrutura da DVA. Oliveira (2008) encontrou essa estrutura em 21 das 44 DVAs analisadas e em 7 dos 16 países com DVA.

Portanto, há duas maneiras de tratar a depreciação: (i) como retenção, neste caso é distribuído entre os fatores de produção o valor adicionado líquido, como mostrado nos modelos brasileiros (FIPECAFI, 2007, p. 502; SANTOS, 2003, p. 39-45; CFC, 2005); (ii) como distribuição, neste caso é distribuído entre os fatores de produção o valor adicionado bruto e a depreciação é acrescida ao lucro retido da companhia, como tratado na proposta inicial do The Corporate Report (MEEK; GRAY, 1988, p. 79).

Meek e Gray (1988, p. 79) argumentam que a segunda abordagem é consistente com o princípio da continuidade, pois o reinvestimento é necessário para compensar a perda da capacidade física produtiva. Essa abordagem tem a vantagem do valor adicionado não ser afetado pela subjetividade envolvida no método de depreciação adotado pela empresa, conferindo comparabilidade e consistência à DVA. Entretanto, esses autores afirmam que há uma série de argumentos em favor da primeira abordagem, e o mais persuasivo é o fato de os ativos fixos que estão sendo depreciados terem sido adquiridos de terceiros, como os materiais e serviços tratados no item anterior.

\footnotetext{
A depreciação representa um custo de aquisição e não tratá-la como tal é, não apenas inconsistente com o tratamento dado às outras aquisições de materiais, mas também, superavalia a riqueza criada durante o período. Além disso, distribuir 100 por cento do valor adicionado bruto poderia eventualmente reduzir seu patrimônio (isso derruba o argumento do investimento para manutenção da capacidade produtiva que favorece o método do valor adicionado bruto!). ${ }^{13}$ (MEEK; GRAY, 1988, p. 79).
}

\footnotetext{
${ }^{13}$ Depreciation represents an input cost and not treating it as such is not only inconsistent with how the other inputs are treated but also overstates the wealth created during the period. Moreover, distributing 100 percent of
} 
Santos (2003, p.49) corrobora com os autores citados e também coloca a questão da consistência do método adotado no modelo FIPECAFI com os conceitos contábeis. Esse autor entende que o problema da subjetividade do método de depreciação adotado pode ser evitado se a contabilidade levar em consideração os valores de mercado de seus ativos (e essa é a tendência da contabilidade mundial) e conclui que "a discussão sobre a depreciação poderia ser resolvida através do aprimoramento de seu cálculo e não da revisão de seu conceito" (p. 49).

Rodrigues, Mello e Lustosa (2007, p.4) realizaram o primeiro estudo empírico no Brasil em busca de evidências sobre a melhor forma de evidenciação da depreciação, mas não encontraram resultados conclusivos devido à limitação do tamanho da amostra. A partir da obrigatoriedade da DVA, o estudo poderá ser refeito, mas é importante reconsiderar a hipótese adotada, já que, teoricamente, o PIB tem relação com o valor adicionado bruto, e o PIL é que teria relação com o valor adicionado líquido (MARTINS, 1993, p. 114).

\subsubsection{Valor adicionado recebido em transferência}

Os valores recebidos em transferência representam valores que a empresa recebe de terceiros, mas não representam sacrifícios operacionais. São investimentos realizados no passado que estão sendo recompensados agora, como é o caso das receitas financeiras, dos ganhos com participações acionárias, do aluguel de imóveis para renda, etc. Esses valores somados ao valor adicionado líquido vão demonstrar o total dos recursos gerados (CUNHA, 2002, p. 39).

Os modelos FIPECAFI e CFC mais uma vez são muito semelhantes. A diferença está apenas nas receitas de aluguéis ou royalties, quando não se tratar da atividade principal da empresa, pois o modelo CFC faz menção explícita a isso, e o modelo FIPECAFI não.

6 - VALOR ADICIONADO RECEBIDO EM TRANSFERÊNCIA (soma dos itens 6.1 e 6.2)

6.1 - Resultado de equivalência patrimonial (inclui os valores recebidos como dividendos relativos a investimentos avaliados ao custo)

O resultado de equivalência poderá representar receita ou despesa; se despesa deverá ser informado entre parênteses.

the firm's gross value added would eventually deplete its capital base (thus turning the physical capital argument favoring the gross method on its head!). 
6.2 - Receitas financeiras (incluir todas as receitas financeiras independentemente de sua origem). (FIPECAFI, 2007, p. 502).

3.7.2.8. Os valores adicionados recebidos (dados) em transferência a outras entidades correspondem:

a) ao resultado positivo ou negativo de equivalência patrimonial;

b) aos valores registrados como dividendos relativos a investimentos avaliados ao custo;

c) aos valores registrados como receitas financeiras relativos a quaisquer operações com instituições financeiras, entidades do grupo ou terceiros, exceto para entidades financeiras que devem classificá-las conforme descrito no item 3.7.2.4 [Receitas]; e

d) aos valores registrados como receitas de aluguéis ou royalties, quando se tratar de entidade que não tenha como objeto essa atividade. (CFC, 2005, p. 2-3).

O título desse grupo é bastante explicativo e trata-se do resultado de um investimento, conforme já explicado. Muitas vezes são valores que aparecem na DVA da empresa que realizou a transferência como distribuição de valor adicionado.

Após esse grupo, a DVA apresenta o "Valor Adicionado Total a Distribuir" que será igual à soma dos lucros retidos com todas as remunerações que aparecem a seguir: empregados, capital de terceiros e capital próprio, e, ainda, a distribuição de valor adicionado para o governo.

\subsubsection{Pessoal e encargos (empregados)}

A distribuição de valor adicionado aos empregados é sempre o primeiro item entre aqueles que compõem a distribuição. Ele representa as despesas da empresa com pessoal considerando todos os valores que beneficiam diretamente os empregados. Por isso, não é considerado neste item o INSS. “Nesse item deverão ser incluídos os encargos com férias, $13^{\circ}$ salário, FGTS, alimentação, transporte, etc., apropriados ao custo do produto ou resultado do período (não incluir encargos com o INSS - veja tratamento a ser dado no item seguinte)" (FIPECAFI, 2007, p. 503).

A parcela de INSS que é despesa da empresa (a parcela do empregado não aparece em nenhum lugar porque não compõe o resultado da empresa, é apenas uma troca de passivos) é, na realidade, um tributo que só beneficiará diretamente o empregado em casos definidos pelo governo. Por exemplo, se uma pessoa contribui por dez anos e depois nunca mais contribui, ela não receberá aposentadoria, nem terá direito a receber o valor pago, ou ainda, uma pessoa que contribui durante quinze anos com o valor mínimo do INSS e uma outra que contribui 
sete anos também com o valor mínimo receberão o mesmo valor de aposentadoria ao se aposentarem por idade. Então, o INSS é um tributo que o governo usa para exercer suas funções de Estado, no caso, distribuição de renda e não um benefício direto ao trabalhador.

O modelo CFC dá instruções um pouco mais detalhadas que o modelo FIPECAFI neste quesito, mas o conteúdo é o mesmo discutido anteriormente:

3.7.2.9. No componente relativo à distribuição do valor adicionado, devem constar:

a) colaboradores - devem ser incluídos salários, férias, $13^{\circ}$ salário, FGTS, seguro de acidentes de trabalho, assistência médica, alimentação, transporte, etc., apropriados ao custo do produto ou ao serviço vendido ou ao resultado do período, exceto os encargos com o INSS, SESI, SESC, SENAI, SENAT, SENAC e outros assemelhados. Fazem parte desse conjunto, também, os valores representativos de comissões, gratificações, participações, planos privados de aposentadoria e pensão, seguro de vida e acidentes pessoais;

b) governo [...];

c) agentes financiadores $[\ldots]$;

d) acionistas $[\ldots]$;

e) participação dos minoritários nos "Lucros retidos" [...];

f) retenção de lucro [...]. (CFC, 2005, p. 3-4).

\subsubsection{Impostos, taxas e contribuições (ou tributos)}

A distribuição de valor adicionado para impostos, taxas e contribuições, na DVA, representa a parcela da remuneração dos fatores de produção que é entregue para financiamento do governo. Apesar de "governo" não ser um fator de produção, a parte do valor adicionado entregue ao Estado é considerada uma forma de distribuição da renda, tanto na visão econômica quanto na DVA. Isso pode ser explicado pela própria função de Estado de redistribuição de renda (STIGITZ, 2000, p.86).

Os modelos FIPECAFI e CFC explicam todos os tributos a serem alocados neste item e destacam a questão dos impostos de valor agregado, pois o valor computado neste item é diferente da forma como os tributos são colocados na DRE. Nesta demonstração, o custo dos produtos aparece líquido no benefício fiscal da compra de produtos com destaque de ICMS, por exemplo, e tributo sobre as vendas aparece pelo valor completo destacado na nota fiscal emitida. Se a empresa não tiver estoques inicial nem final, o valor será o mesmo, mas quando ela mantém produtos em estoque, ela pode acumular créditos de ICMS. Então, não é possível identificar na DRE a tributação real do produto. Na DVA, deverá aparecer neste item a tributação real, como explicam os modelos. 
8.2 - Impostos, taxas e contribuições

Além das contribuições devidas ao INSS, imposto de renda, contribuição social, todos os demais impostos, taxas e contribuições deverão ser incluídos neste item. Os valores relativos ao ICMS e IPI deverão ser considerados como os valores devidos ou já recolhidos aos cofres públicos, representando a diferença entre os impostos incidentes sobre as vendas e os valores considerados dentro do item 2 - Insumos adquiridos de terceiros. (FIPECAFI, 2007, p. 503).

3.7.2.9. No componente relativo à distribuição do valor adicionado, devem constar:

a) colaboradores $[\ldots]$;

b) governo - devem ser incluídos impostos, taxas e contribuições, inclusive as contribuições devidas ao INSS, SESI, SESC, SENAI, SENAT, SENAC e outros assemelhados, imposto de renda, contribuição social, ISS, CPMF, todos os demais tributos, taxas e contribuições. Os valores relativos a ICMS, IPI, PIS, Cofins e outros assemelhados devem ser considerados os valores devidos ou já recolhidos aos cofres públicos, representando a diferença entre os impostos incidentes sobre as vendas e os valores considerados dentro do item "Insumos adquiridos de terceiros". Como os tributos são, normalmente, contabilizados no resultado como se devidos fossem, e os incentivos fiscais, quando reconhecidos em conta de reserva no patrimônio líquido, os tributos que não forem pagos em decorrência de incentivos fiscais devem ser apresentados na Demonstração do Valor Adicionado como item redutor do grupo de tributos;

c) agentes financiadores [...];

d) acionistas $[\ldots]$;

e) participação dos minoritários nos "Lucros retidos" [...];

f) retenção de lucro [...]. (CFC, 2005, p. 3-4).

Sem dúvida, a maneira como a tributação da empresa é tratada na DVA é um diferencial da demonstração. Essa informação, a carga tributária total da empresa, só é fornecida na DVA. E estudos brasileiros já analisaram a carga tributária setorial, usando a distribuição de valor adicionado para o governo (por exemplo, GALLO, PEREIRA e LIMA, 2006; GALLO, 2007; SANTOS, 1999; SANTOS e HASHIMOTO, 2003).

A carga tributária apresentada aparece líquida dos incentivos fiscais recebidos. Rodrigues Júnior (2003) mostra a utilidade da DVA como meio de mensuração dos efeitos sociais e econômicos decorrentes dos incentivos fiscais e sugere que a demonstração seja referência também na decisão de concessão de incentivos fiscais.

Cosenza (2003, p. 15) afirma que, para uma melhor evidenciação da carga tributária, "o ideal seria especificar os impostos conforme suas competências segundo a unidade federativa que os originou, por exemplo, da União, do Estado ou do Município, ou, ainda, de um País estrangeiro". O modelo aprovado pelo CPC, em vigor, atualmente, no Brasil, prevê essa evidenciação em sua estrutura, com exceção de tributação gerada por outro país (CPC, 2008b). 
McLeay (1983) e Meek e Gray (1988) mostram que as companhias evidenciam a distribuição de valor adicionado para o governo de uma série de maneiras diferentes, entre elas: impostos sobre a folha de salários considerados distribuição para o governo ou para os empregados; impostos sobre mercadorias considerados como redução da receita e dos insumos adquiridos de terceiros (como na DRE) ou como distribuição para o governo; impostos retidos dos empregados como distribuição de valor ao governo. McLeay (1983, p. 46) defende que a maneira como a empresa evidencia a distribuição de valor adicionado para o governo está relacionada com a maneira como a empresa "enxerga" o governo, isto é, governo como um coletor de impostos ou governo como setor público, com as funções atribuídas ao Estado.

Por fim, uma questão importante deve ser levantada, convergente com o problema de pesquisa deste trabalho. As empresas podem destinar até $6 \%$ do imposto de renda que pagariam para o governo para determinados projetos de instituições filantrópicas. Esse valor referente ao imposto de renda, mas entregue a uma instituição do Terceiro Setor, é uma distribuição de valor adicionado para o governo? Esta questão será discutida no item 3.3.10.

\subsubsection{Juros e aluguéis (ou financiadores)}

A distribuição de valor adicionado para juros e aluguéis representa a remuneração do capital de terceiros. Em aluguéis inclui-se a remuneração pelo uso de ativos tangíveis e intangíveis (royalties e franquias). De Luca (1996, p. 103) aponta mais uma diferença entre o cálculo do valor adicionado na contabilidade e o cálculo do IBGE. Este último considera o pagamento de aluguel de bens tangíveis como consumo intermediário, ou seja, insumos adquiridos de terceiros e não remuneração do capital de terceiros.

O modelo FIPECAFI considera neste item "as despesas financeiras e as de juros relativas a quaisquer tipos de empréstimos e financiamentos junto a instituições financeiras, empresas do grupo ou outras e os aluguéis (incluindo-se as despesas com leasing) pagos ou creditados a terceiros" (FIPECAFI, 2007, p. 503). O modelo CFC traz exatamente o mesmo conteúdo e adiciona que, quando for DVA de instituição financeira, os juros devem ser tratados como insumos adquiridos de terceiros (CFC, 2005, p. 3). Conforme já citado, Santos (2003, p. 43) traz um modelo específico para instituições financeiras. 


\subsubsection{Juros sobre capital próprio, dividendos e lucros retidos}

Este último item refere-se à remuneração do capital próprio e ao reinvestimento dos lucros na companhia. Na realidade, ambos representam a remuneração do acionista, pois o lucro é o próprio retorno do acionista. A evidenciação na DVA acontece quase sempre de forma separada, uma linha para dividendos e outra para lucros retidos, tanto no exterior (OLIVEIRA, 2008) quanto nos modelos brasileiros, FIPECAFI e CFC.

\section{4 - Juros sobre o capital próprio e dividendos}

Inclui os valores pagos ou creditados aos acionistas. Os juros sobre o capital próprio contabilizados como reserva deverão constar do item "lucros retidos".

8.5 - Lucros retidos/prejuízo do exercício

Devem ser incluídos os lucros do período destinados às reservas de lucros e eventuais parcelas ainda sem destinação específica. (FIPECAFI, 2007, p. 503).

3.7.2.9. No componente relativo à distribuição do valor adicionado, devem constar:

a) colaboradores $[\ldots]$;

b) governo $[\ldots]$;

c) agentes financiadores $[\ldots]$;

d) acionistas - incluem os valores pagos ou creditados aos acionistas, a título de juros sobre o capital próprio ou dividendos. Os juros sobre o capital próprio apropriados ou transferidos para contas de reservas no patrimônio líquido devem constar do item "Lucros retidos";

e) participação dos minoritários nos "Lucros retidos" - deve ser incluído neste componente, aplicável às Demonstrações Contábeis Consolidadas, o valor da participação minoritária apurada no resultado do exercício, antes do resultado consolidado;

f) retenção de lucro - deve ser indicado neste componente o lucro do período destinado às reservas de lucros e eventuais parcelas ainda sem destinação específica. (CFC, 2005, p. 3-4).

Martins (1993) enfatiza a necessidade de evidenciar os lucros retidos separadamente dos lucros distribuídos, mas ambos como subtítulo do grupo acionistas, pois "a colocação desses lucros retidos da empresa fora do subgrupo Sócios pode inclusive dar a idéia, que pode não ser verdadeira, de a administração querer estar escondendo o total do valor adicionado que pertence aos seus proprietários” (p. 128).

\subsubsection{DVA x DRE x EVA}

Santos e Carvalho (1997, p. 132) lembram a importância de observar que a DVA não deve ser confundida com a Demonstração de Resultados do Exercício ou com o Economic Value Added (EVA)"14. Assim, este tópico tem o objetivo de diferenciar esses conceitos.

\footnotetext{
${ }^{14}$ Marca registrada da Stern Stewart \& Co.
} 
O Economic Value Added $\left(\mathrm{EVA}^{\circledR}\right)$ é uma das, talvez a mais famosa, medidas de lucro residual utilizada para avaliar o retorno do investimento do acionista. A teoria de valor econômico agregado utiliza termos muito parecidos com aqueles utilizados quando se discute a DVA. O valor econômico agregado representa a riqueza gerada para o acionista e é mensurado excluindo do lucro operacional ajustado pelos impostos o custo médio ponderado do capital investido. Portanto, mostra quanto o investidor acrescentou de valor à sua riqueza por optar por determinado investimento e não pela melhor alternativa disponível (YOUNG; O’BYRNE, 2003, p. 33-55).

$\mathrm{O} \mathrm{EVA}^{\circledR}$ é muito diferente da DVA. Enquanto o primeiro tem foco na riqueza gerada para o acionista, a segunda tem foco na riqueza gerada para a sociedade. O primeiro se constitui em informação financeira voltada para o investidor, enquanto a segunda se preocupa em informar a geração e distribuição de riqueza para todos os stakeholders da firma, inclusive investidores. O primeiro depende de informações não contabilizadas (custo de oportunidade do capital próprio), já a segunda é elaborada somente com informações da contabilidade financeira da empresa. Assim, não se deve confundir esse dois conceitos tão diferentes.

Assim como o EVA ${ }^{\circledR}$, a DRE também é uma informação voltada para o acionista. Essa talvez seja a grande diferença entre a DVA e a DRE. Para Martins (1997, p. 1), a DRE mostra uma visão particular, de apenas um dos grupos interessados da empresa, os seus proprietários, ao passo que a DVA traz uma visão muito mais geral, dando a mesma importância a todos os fatores de produção. Santos (2003, p. 15) chega a qualificar a DRE como uma demonstração “extremamente exclusivista" devido ao enfoque dado ao lucro que só interessa aos sócios.

Meek e Gray (1988, p. 75) observam a existência de muitas informações em comum nas duas demonstrações, mas não concordam com uma das críticas à DVA, a falta de informações adicionais sobre a empresa. Esses autores ressaltam a questão do gasto com trabalho e depreciação para contradizer essa visão, pois a DRE traz parte destes custos embutidos no custo dos produtos vendidos e não é possível identificar o total gasto com empregados e depreciação nessa demonstração, ao contrário da DVA.

A norma internacional IAS 1, conforme já citado, trata da apresentação das demonstrações contábeis. Ao tratar da DRE, a norma faculta a empresa a escolher entre duas classificações 
de despesas: por natureza (por exemplo: despesa de materiais, despesas com pessoal, despesas de depreciação, entre outras) ou por função (por exemplo: custo da mercadoria vendida, custos de distribuição, despesas administrativas etc.). A empresa deverá escolher aquela que fornecer a informação mais fidedigna e mais relevante para a tomada de decisão. Entretanto, as entidades que usarem a classificação por função devem evidenciar informação adicional sobre a natureza dos gastos, incluindo gastos de amortização e depreciação e despesas com empregados (IASB, 2007, p. 797-798).

Pode-se afirmar que, no Brasil, a DRE é apresentada atualmente, pela maior parte das empresas, com a classificação de despesas por função. Já a DVA, conforme as características da sua estrutura, apresenta os gastos classificados por natureza. Nesse contexto, a DVA assume também a função de complementar a DRE para atender às normas internacionais. Essa é mais uma evidência de que as demonstrações são complementares.

\subsubsection{Evidenciação dos investimentos socioambientais na DVA}

Este tópico tem por objetivo mostrar como são tratados os investimentos socioambientais atualmente na DVA, mostrar como a mudança no tratamento (redução ou distribuição de valor adicionado) altera o valor da riqueza gerada pela empresa e apresentar o modelo de DVA proposto pelo GRI.

Qualquer investimento socioambiental realizado pela empresa, que não se inclua em seu processo produtivo, será contabilizado como uma despesa e assim será tratado na DRE. Entretanto, conforme já citado, a DRE reflete a visão do acionista. O valor adicionado entregue aos empregados e ao governo também é considerado despesa quando contabilizado. Isso mostra que a contabilização, realizada conforme o plano de contas da empresa, segue a ótica do acionista.

Atualmente, no Brasil, a DVA é realmente um rearranjo da DRE porque todas as receitas e despesas que aparecem nesta demonstração estarão somadas também naquela. Assim, se os investimentos socioambientais privados são despesas, eles já aparecem na DVA das empresas que a publicam. Os modelos FIPECAFI e CFC não preveem uma linha específica para evidenciar esses investimentos, nem na parte de formação do valor adicionado nem em sua 
distribuição. Isso significa que os investimentos sociais vêm sendo somados aos insumos adquiridos de terceiros.

Este trabalho estuda se os investimentos socioambientais poderiam figurar como distribuição de valor adicionado, como algumas empresas já o fazem. Questiona-se: faz diferença? O exemplo apresentado na Tabela 5 mostra o impacto dos investimentos socioambientais no valor adicionado bruto, valor correspondente ao PIB, ou à riqueza bruta adicionada pela empresa para a sociedade.

Tabela 5 - Simulação de DVA com investimentos sociais destacados como distribuição de VA

\begin{tabular}{|c|c|c|}
\hline Demonstração do Valor Adicionado & $\mathbf{A}$ & $\mathbf{B}$ \\
\hline 1. RECEITAS & $15.520,00$ & $15.520,00$ \\
\hline 1.1 Vendas de mercadoria, produtos e serviços & $16.000,00$ & $16.000,00$ \\
\hline 1.2 Provisão para devedores duvidosos - & & \\
\hline Reversão/(Constituição) & $(480,00)$ & $(480,00)$ \\
\hline 1.3 Não operacionais & - & - \\
\hline 2 INSUMOS ADQUIRIDOS DE TERCEIROS & $6.810,00$ & $6.760,00$ \\
\hline 2.1 Matérias-primas consumidas & - & - \\
\hline 2.2 Custos das mercadorias e serviços vendidos & $6.640,00$ & $6.640,00$ \\
\hline 2.3 Materiais, energia, serviços de terceiros e outros & 170,00 & 120,00 \\
\hline 2.4 Perda / Recuperação de valores ativos & & \\
\hline 3 VALOR ADICIONADO BRUTO $(1-2)$ & &, 00 \\
\hline 4 RETENÇÕES & 0 & 600,000 \\
\hline 4.1 Depreciação, amortização e exaustão & 600,00 & 600,00 \\
\hline 5 VA LÍQUIDO PRODUZIDO PELA ENTIDADE (3-4) & $8.110,00$ & $8.160,00$ \\
\hline 6 VA RECEBIDO EM TRANSFERÊNCIA & 150,00 & 150,00 \\
\hline 6.1 Resultado da equivalência patrimonial & - & - \\
\hline 6.2 Receitas financeiras & 150,00 & 150,00 \\
\hline 7 VA TOTAL A DISTRIBUIR $(5+6)$ & $8.260,00$ & $8.310,00$ \\
\hline 8 DISTRIBUIÇÃO DO VALOR ADICIONADO $(8=7)$ & $8.260,00$ & $8.310,00$ \\
\hline 8.1 Pessoal e Encargos & $3.240,00$ & $3.240,00$ \\
\hline 8.2 Impostos, taxas e contribuições & $2.455,00$ & $2.455, \Omega Q$ \\
\hline Investimentos Sociais & 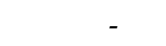 & 50,00 \\
\hline 8.3 Juros e aluguéis & 250,00 & $250,000^{\circ}$ \\
\hline 8.4 Juros sobre capital próprio e dividendos & 926,00 & 926,00 \\
\hline 8.5 Lucros retidos / prejuízo do exercício & $1.389,00$ & $1.389,00$ \\
\hline
\end{tabular}

A. DVA conforme modelo FIPECAFI

B. DVA com Investimentos Socioambientais como distribuição de valor adicionado

Os valores destacados (circunscritos com linhas pontilhadas) representam a contribuição da empresa fictícia para o PIB brasileiro (considerando a ótica de valor adicionado contábil). A diferença entre os dois valores é exatamente o valor dos investimentos socioambientais privados realizados no período (também circunscrito). A empresa realizou investimento de aproximadamente $0,3 \%$ da receita de vendas, e o impacto no valor adicionado bruto foi superior a $0,5 \%$. 
Em 2004, as empresas investiram 4,7 bilhões de reais no atendimento de comunidades carentes, o que representou aproximadamente 0,3\% do PIB brasileiro no mesmo ano (IPEA, 2006, p. 17). Então, esse seria o tamanho da diferença no cálculo do PIB pela soma das DVAs devido à classificação dos investimentos sociais de maneira incoerente com a metodologia de cálculo do PIB.

Conforme já mencionado, os investimentos sociais privados recebem incentivos do governo por meio de benefícios tributários. O governo permite deduzir parte dos investimentos realizados do valor devido de imposto de renda. Essa postura é coerente com a postura de um Estado menos centralizador e mais regulador. Ou seja, o Estado transfere para o mercado tarefas relacionadas à sua função de prover o bem-estar social. O mercado assume essa função e se beneficia disso melhorando sua imagem perante a sociedade.

Se o governo oferece incentivos fiscais para algumas atividades de responsabilidade social empresarial, ele reconhece os benefícios trazidos para o bem-estar da sociedade. Então, no caso dos benefícios fiscais para incentivo a atividades de esporte, cultura e assistência social, qual o tratamento contábil a ser dado para esses benefícios? O benefício em questão é um redirecionamento de uma despesa que a empresa tem independente do investimento social. Explica-se: uma empresa que teria $\mathrm{R} \$ 5.000$ de imposto de renda a pagar pode destinar $\mathrm{R} \$ 50$ para Fundos Municipais dos Direitos das Crianças e Adolescentes (FMDCA). Se ela optar por destinar o valor ao fundo municipal em questão, o imposto recolhido passa a ser $\mathrm{R} \$ 4.950$. Então, a despesa total é R $\$ 5.000$, independente da opção da empresa.

Entretanto, a contabilização é diferente. Na opção 1 (empresa não destina valor ao FMDCA), a empresa contabiliza $\mathrm{R} \$ 5.000$ como despesa de imposto de renda contra imposto de renda a pagar no encerramento do exercício contábil. Na opção 2 (empresa destina valor ao FMDCA), a empresa deve realizar o pagamento para o fundo dentro do exercício contábil. Assim, durante o exercício, a empresa contabiliza $\mathrm{R} \$ 50$ como despesa com investimentos sociais contra caixa ou banco e, no encerramento do exercício, contabiliza $\mathrm{R} \$ 4.950$ como despesa de imposto de renda contra imposto de renda a pagar (CRC-SP, 2007).

Obviamente a DRE será diferente nas duas situações. Por conseqüência, a DVA também será: a opção 1 mostra distribuição de valor adicionado ao governo de $\mathrm{R} \$ 5.000$ e a opção 2, 
$\mathrm{R} \$ 4.950$; a opção 1 possui valor adicionado bruto produzido pela entidade $\mathrm{R} \$ 50$ maior que a opção 2. Questiona-se: a contribuição da empresa para sociedade é maior na opção 1 que na opção 2? Em valores monetários, não.

Por outro lado, é importante pensar que a empresa poderá utilizar sua contribuição ao FMDCA (ou ao patrocínio de atividades esportivas ou culturais e outras opções) como ferramenta para melhorar sua imagem junto aos consumidores, ou seja, marketing. Assim, retoma-se a discussão: a empresa está realizando um investimento social ou uma despesa de marketing?

A Global Reporting Iniciative defende a posição dos investimentos sociais como distribuição de valor. Este tópico sobre estrutura da DVA não pode deixar de apresentar esse modelo, apesar de sua utilização estar, atualmente, restrita aos Balanços Sociais.

Conforme já exposto, o GRI apresenta indicadores de desempenho econômico, ambiental e social divididos em seis categorias: econômico, ambiental, práticas trabalhistas e trabalho decente, direitos humanos, sociedade e responsabilidade pelo produto. O primeiro dos indicadores de desempenho da categoria "econômico" (EC1) é o "valor econômico direto gerado e distribuído, incluindo receitas, custos operacionais, remuneração de empregados, doações e outros investimentos na comunidade, lucros acumulados e pagamentos para provedores de capital e governos" (GRI, 2006, p. 27).

Para cada categoria de indicadores, foi desenvolvido um conjunto de protocolos que mostra a relevância do indicador, ensina a calcular e a evidenciar o indicador e traz outras referências a serem consultadas para o desenvolvimento do indicador. É importante ressaltar a proximidade do GRI com a contabilidade. As normas contábeis do IASB são citadas como referências em diversos indicadores, e alguns princípios do desenvolvimento do relatório fazem parte da estrutura conceitual da contabilidade (relevância e materialidade, por exemplo).

O protocolo de desenvolvimento do EC1 propõe uma tabela que se aproxima da DVA em sua estrutura. $\mathrm{O}$ objetivo desse indicador é fornecer uma "indicação básica de como a organização gerou riqueza para seus stakeholders" (GRI, 2006, p. EC4). A tabela, intitulada Tabela de Valor Econômico Gerado e Distribuído - EVG\&D - pelo GRI, está exposta no Quadro 6. 
Quadro 6 - Tabela de Valor Econômico Gerado e Distribuído - EVG\&D - pelo GRI

\begin{tabular}{|l|l|}
\hline Componente & Comentário \\
\hline Valor econômico direto gerado & $\begin{array}{l}\text { Vendas líquidas mais receitas provenientes de investimentos } \\
\text { financeiros e vendas de ativos. }\end{array}$ \\
\hline a) Receitas & $\begin{array}{l}\text { Pagamentos para fornecedores, investimentos não estratégicos, } \\
\text { royalties e pagamentos de facilitação. }\end{array}$ \\
\hline b) Custos operacionais & $\begin{array}{l}\text { Total da folha de pagamento para empregados (pagamentos atuais } \\
\text { e não obrigações futuras). }\end{array}$ \\
\hline c) Salários e benefícios de empregados & $\begin{array}{l}\text { Todos os pagamentos financeiros feitos aos provedores de capital } \\
\text { da organização. }\end{array}$ \\
\hline d) Pagamentos para provedores de capital \\
\hline e) Pagamentos ao governo (por país) & Impostos brutos. \\
\hline f) Investimentos na comunidade & $\begin{array}{l}\text { Contribuições voluntárias e investimento de fundos na } \\
\text { comunidade como um todo (inclui doações). }\end{array}$ \\
\hline $\begin{array}{l}\text { Valor econômico acumulado } \\
\text { (calculado como Valor econômico gerado } \\
\text { menos Valor econômico distribuído) }\end{array}$ & Investimentos, hipotecas, etc. \\
\hline FONTE: GRI (2006, p. EC5)
\end{tabular}

FONTE: GRI (2006, p. EC5)

Apesar das semelhanças na estrutura, existem algumas diferenças conceituais entre o protocolo do indicador EC1 e a DVA, não obstante muitas empresas divulguem a DVA como resposta a esse requisito GRI. A primeira diferença é que não há conciliação da DVA com a DRE, isto é, a tabela EVG\&D não apresenta todos os itens de resultado da empresa. A segunda diferença é a classificação de fornecedores entre os stakeholders que "recebem" a distribuição de valor, mostrando que não há relação entre o conceito econômico de valor adicionado e o conceito adotado pelo GRI. A terceira diferença é a distribuição de valor para a comunidade, questão discutida neste trabalho.

É provável que as empresas que apresentam investimentos sociais como distribuição de valor, mostradas na introdução deste trabalho, tenham sido influenciadas mais por este modelo GRI de "demonstração do valor adicionado" que por conceitos econômicos de fato.

\subsection{Vantagens e limitações da DVA}

A Demonstração do Valor Adicionado é recente no Brasil. Apesar de já haver um crescente número de empresas que publicam a demonstração, conforme mostrado na introdução deste trabalho, muitas empresas ainda estão aprendendo como elaborar a demonstração. $\mathrm{O}$ ano de 2008 é o primeiro em que a DVA é obrigatória para as companhias de capital aberto (Lei $\mathrm{n}^{\mathrm{O}}$. 11.638/07). Por isso, a discussão sobre limitações e diferenciais da DVA é importante no contexto atual. 
Suojanen (1954, p. 397-398), um dos primeiros textos a tratar do assunto DVA, traz algumas vantagens do conceito de valor adicionado como medida de resultado. A primeira fala da maior abrangência da DVA por estar voltada a todos os participantes com os quais a empresa tem contínua responsabilidade. Quando a empresa é vista como uma pessoa ou um proprietário, a DRE é a demonstração adequada, mas quando a empresa é vista como um negócio, ou uma instituição, a DVA reflete melhor o desempenho da empresa. Usando esta abordagem, o pagamento de salários pela empresa aos empregados tem o mesmo significado, "dollar for dollar", que os dividendos distribuídos aos acionistas. A segunda vantagem fala de informações importantes sobre o desenvolvimento econômico que poderiam ser fornecidas para o governo, de modo que informações econômicas fossem transmitidas com maior velocidade, melhorando as atividades de planejamento do Estado (isso em 1954, quando telefone era artigo de luxo!). Por fim, o texto fala da vantagem da contabilidade financeira não ter de sofrer alterações significativas para fornecer a "informação suplementar" do valor adicionado.

Morley (1979) aumenta o número de vantagens da DVA, mas também apresenta suas desvantagens. O autor corrobora com a última vantagem exposta por Suojanen (1954, p. 398) e afirma que a DVA é elaborada com base nos mesmos princípios contábeis adotados na contabilidade, como continuidade, competência, consistência, objetividade e essência sobre a forma (MORLEY, 1979, p. 623).

Morley (1979, p. 622) corrobora também com a segunda vantagem exposta por Suojanen (1954, p. 398) quando expõe como vantagem o fato de a DVA relacionar a contabilidade da empresa à renda nacional. Morley afirma, ainda, que o valor adicionado da empresa corresponde à sua contribuição para a renda nacional e que a soma do valor adicionado de cada companhia seria igual à renda nacional. Santos e Carvalho também ressaltam essa vantagem.

Outra grande vantagem da DVA está no fato de que, se todas as empresas a elaborarem, a consolidação de seus valores comporia parte substancial da riqueza interna gerada no país, ou seja, o produto interno bruto - PIB. Nesse caso, teríamos o trunfo de não mais trabalhar com valores estimados na fixação do PIB, pois parte determinante de seus componentes passaria a ter maior grau de credibilidade. Em última análise, podemos até afirmar que parcela significativa do nosso PIB passaria por um devido processo de auditoria, uma vez que boa parte das empresas, que são as maiores criadoras de riquezas, é normalmente auditada. (SANTOS E CARVALHO 1997, p. 132). 
Cunha (2002, p. 176) complementa essa ideia com a necessidade de a DVA ser evidenciada de maneira descentralizada em cada região onde a empresa atua, para que as informações possam ser analisadas em conjunto com os dados do IBGE sobre a renda local. Sugere ainda que a DVA apresente o número de empregados no início e fim do período, permitindo à sociedade acompanhar a evolução dos postos de trabalho em cada empresa.

\begin{abstract}
A avaliação da empresa com relação à economia setorial, regional, ou nacional pode ser obtida através da comparação entre o seu valor adicionado (riqueza criada da empresa) e o valor adicionado da economia (PIB) setorial, regional ou nacional, desde que ambos utilizem as mesmas bases conceituais de mensuração. (DE LUCA, 1996, p. 91).
\end{abstract}

Cunha, Ribeiro e Santos (2005, p. 9) definem a DVA como um relatório contábil capaz de demonstrar tanto os benefícios que as organizações oferecem para a sociedade quanto a capacidade da empresa de gerar riqueza para a economia e contribuir para o desenvolvimento econômico. Ribeiro e Cunha (2003, p.13) materializam esse conceito por meio de análise empírica:

As DVAs analisadas permitiram observar que as empresas aumentaram suas parcelas de contribuição na composição riqueza do país. Na análise do valor distribuído observou-se que o governo é o agente que mais consome os recursos gerados pelas empresas; os empregados ocupam a segunda posição, no entanto, em forte declínio, movimento este oposto ao da remuneração de terceiros. Ou seja, as companhias estão contribuindo mais para o desenvolvimento econômico e social do país: econômico quando produzem mais riqueza, social quando repassam os impostos ao governo para que este promova o bem-estar geral da nação. Lamentavelmente, estão empregando menos. (RIBEIRO; CUNHA, 2003, p. 13).

Quanto à primeira vantagem levantada por Suojanen (1954, p. 397) a qual coloca a DVA como ferramenta que reflete melhor o esforço da empresa enquanto equipe em busca de resultado comum, não há consenso sobre o assunto. É uma questão ambígua, pois pode despertar rivalidade entre os grupos, como ocorreu no Reino Unido.

Morley (1979, p. 620) afirma que a DVA melhora a atitude dos empregados com relação às empresas, e isso ocorre porque a demonstração traz uma visão mais abrangente dos objetivos e das responsabilidades da empresa. $\mathrm{O}$ valor adicionado da firma representa a riqueza criada disponível para a equipe que contribuiu para tanto. E os empregados são tidos como responsáveis também, então eles ficam motivados porque são informados de seus resultados.

A DVA pode ser utilizada para reduzir os custos políticos impostos à empresa, por exemplo, por empregados, sindicatos e governo, já que a DRE evidencia os lucros altos, e a DVA 
destaca também a parcela da riqueza distribuída para esses grupos. De acordo com a teoria dos custos políticos da contabilidade, as empresas tendem a evitar as reações adversas geradas por lucros altos por meio de ações que beneficiem os empregados ou a comunidade, como investimentos sociais privados. As evidenciações voluntárias de informações financeiras se justificam como estratégia para reduzir os custos políticos (WATTS; ZIMMERMAN, 1978; DEEGAN, 2002).

A interdependência entre os vários grupos de stakeholders é enfatizada pela DVA, assim como o efeito interativo das decisões de qualquer grupo nos demais. Isso pode gerar maior coesão entre os stakeholders e uma atitude mais positiva dos empregados em relação à empresa. Por outro lado, pode evidenciar discrepâncias nas remunerações dos fatores de produção, gerando competitividade e rivalidade entre os grupos (MEEK; GRAY, 1988, p. 78).

De fato, o próprio Morley $(1979$, p. 623) já colocou isso como uma limitação da DVA, pois apesar da ideia de enxergar a empresa como um conjunto de equipes que cooperam para compor o valor adicionado, a remuneração dessa cooperação pode não ser proporcional à contribuição para a formação de valor. O governo, por exemplo, não foi “convidado" para se juntar à equipe, não participa da tomada de decisão, mas recebe, muitas vezes, a maior parte do valor adicionado.

\footnotetext{
Nem sempre há coincidência entre o que os diferentes agentes econômicos esperam da repartição do valor adicionado e aquilo que finalmente foi obtido. Quando ocorre esta discrepância, aumenta a tensão interna na empresa, o que poderá resultar em diversas categorias de problemas e conflitos para a sua gestão, como impasses junto à classe trabalhadora, demandas de maiores retornos dos acionistas, incrementos de impostos, negativas à renegociação de dívidas e aumento de cargas financeiras. (COSENZA, 2003, p. 10).
}

Soujanen (1954, p. 392-395) define a empresa como um centro de tomada de decisões em que as decisões afetam diversos grupos com interesses diferentes. E acrescenta que o corpo de pessoas que compõem a diretoria ou a administração da empresa, e também são empregados da firma, não pode "dividir sua lealdade" e tem de assumir uma postura de pensar em todos os stakeholders, independente de participar de um deles especificamente. Entretanto, a teoria da agência de Jensen e Meckling (1976) mostra que os administradores tendem a agir em seu próprio interesse, gerando um conflito de interesses entre eles e os acionistas. 
Morley (1979, p. 621) ainda coloca como vantagem a facilidade trazida pela DVA para a introdução de um esquema de bonificação por produtividade para empregados, baseado no valor adicionado. O autor defende a inclusão da DVA no relatório anual para ampliar o conhecimento e a confiabilidade no valor adicionado, pois isso aumenta a adesão dos empregados ao plano de bonificação.

Como a DVA evidencia a geração de riqueza pela empresa e sua forma de distribuição aos agentes que colaboraram na sua criação, constitui-se numa visão nova para os trabalhadores sobre o desempenho das entidades. Por meio dessa demonstração, é possível aos trabalhadores avaliarem a oscilação da riqueza que a empresa produziu, acompanhar a parcela que está sendo levada por eles e, assim, conscientemente, lutar por aumentos reais de salários e de incentivos, em virtude desse acréscimo na riqueza. (CUNHA, RIBEIRO e SANTOS, 2005, p.10).

Entretanto, novamente isso pode trazer resultados adversos. Vale lembrar o estudo já citado neste trabalho em que Pong e Mitchell (2005, p. 193-194) concluem que as informações contidas na DVA não se constituem como um mecanismo adequado para resolver as disputas de natureza trabalhista. No Reino Unido, ao examinar a distribuição de valor adicionado para empregados, geralmente, esse parecia ser o grupo de stakeholder mais favorecido da empresa. Isso em nada ajudava em negociações sindicais e ainda podia ter um reflexo ruim para a administração na avaliação dos acionistas. Assim, a evidenciação da distribuição do valor adicionado não era exatamente uma estratégia para estimular a cooperação entre os stakeholders, ao contrário, acabou sendo uma forma de fomentar conflitos de interesses entre eles.

Morley (1979, p. 621) coloca, ainda, como vantagem da DVA, os indicadores de desempenho baseados em valor adicionado, ferramentas úteis para diagnóstico e predição de resultados. Com isso, poderiam ser avaliadas tendências de desempenho, ser realizadas comparações entre companhias do mesmo setor e com outros países. Um indicador da remuneração de empregados, por exemplo, poderia ser útil como ferramenta de barganha para aumento de salário. Outro indicador poderia comparar a carga tributária das empresas em países diferentes.

A DVA pode ser utilizada para analisar aspectos referentes ao ambiente interno e externo à empresa. Para análise de ambiente interno, são propostos indicadores que relacionam valor adicionado com número de empregados, folha de pagamento, vendas e lucro operacional. Quanto ao ambiente externo, a DVA "proporciona análises sobre a participação da empresa no cenário econômico onde ela atua", como avaliação da contribuição da empresa à sociedade 
por meio de pagamento de impostos; avaliação do nível de remuneração da força de trabalho; avaliação da contribuição da empresa para a produção de riqueza da economia setorial, local e nacional, inclusive por comparações entre empresas concorrentes (DE LUCA, 1996, p. 91).

Santos (2003, p. 219-228) propõe uma série de indicadores baseados no valor adicionado e outras informações da DVA. O Quadro 7 mostra alguns dos indicadores propostos pelo autor.

Quadro 7 - Exemplos de indicadores de avaliação de desempenho baseados na DVA, proposto
SANTOS (2003, p. 219-228)
\begin{tabular}{ll|}
\hline Produtividade da mão de obra & Valor Adicionado \\
Produtividade das vendas & $\frac{\mathrm{N}^{\mathrm{o}} \text { de Empregados }}{\text { Valor Adicionado }}$ \\
Remuneração do capital em relação ao ativo & Faturamento \\
Carga tributária da empresa & VA Terceiros + VA Acionistas \\
\cline { 2 - 3 } & Ativo Total \\
\end{tabular}

Morley (1979, p. 622) mostra, por meio de exemplos, que o valor adicionado oferece melhor proxy para mensuração de tamanho da empresa para as indústrias, superando as medidas tradicionais de vendas e capital empregado. Entretanto, os exemplos referem-se a casos específicos, por isso, não é possível estender a crítica do autor a todos os casos. Um estudo empírico poderia comprovar isso.

Estudos empíricos avaliaram a relevância da informação do valor adicionado, entre eles: Bao e Bao (1989), Riahi-Belkaoui e Fekrat (1994), Riahi-Belkaoui e Picur (1994), Bao e Bao (1998) e Scherer (2006).

Bao e Bao (1989 e 1998) realizaram dois estudos com o objetivo de avaliar a relevância do valor adicionado. Vale ressaltar que o valor adicionado dos estudos foi calculado pelos pesquisadores, já que as empresas americanas não divulgam a DVA. No primeiro (BAO e BAO, 1989), os autores constatam que o valor adicionado pode ser usado como proxy de produtividade. No segundo (BAO e BAO, 1998), eles investigaram a relevância do valor adicionado líquido e do $\mathrm{EVA}^{\circledR}$ em relação ao lucro. A amostra foi composta por 166 empresas americanas em dois anos, 1992 e 1993. Para o EVA ${ }^{\circledR}$, os resultados encontrados não foram estatisticamente significativos. Mas o valor adicionado líquido se mostrou uma variável explicativa estatisticamente significante em todas as análises, e seu poder explicativo foi 
maior que o poder explicativo do lucro. Portanto, valor adicionado líquido é relevante, ou seja, tem conteúdo informativo na avaliação da empresa para a amostra estudada.

Riahi-Belkaoui e Fekrat (1994) examinaram empiricamente indicadores de desempenho evidenciados na DVA em comparação com indicadores tradicionais da Demonstração de Resultados e da Demonstração dos Fluxos de Caixa. A amostra utilizada era composta por 673 empresas norte-americanas no período de 1981 a 1990. Esses autores mostram que os indicadores baseados no valor adicionado líquido têm menor variabilidade e maior persistência que indicadores correspondentes baseados em lucro e fluxo de caixa.

\begin{abstract}
Menor variabilidade e maior persistência combinadas com uma associação mais robusta com as medidas de risco baseadas no mercado e uma medida superior de desempenho gerencial tornam os dados contábeis baseados em valor adicionado potencialmente muito mais importantes e informativos que os dados atualmente derivados da Demonstração de Resultado e Demonstração dos Fluxos de Caixa. A intenção não é sugerir que os dados contábeis utilizados neste momento sejam descontinuados ou abandonados, mas dado o custo aparentemente baixo de produzir informações de valor adicionado e o benefício potencialmente alto a ser gerado por elas, deveria ser dada mais atenção para a inclusão dessas informações na rotina das empresas. (RIAHIBELKAOUI; FEKRAT, 1994, 1999, p. 9, tradução livre) ${ }^{15^{3}}$.
\end{abstract}

Riahi-Belkaoui e Picur (1994) avaliaram o incremento da informação fornecida pelo valor adicionado líquido em relação aos lucros na avaliação de títulos mobiliários. A amostra incluiu todas as empresas com ações negociadas na Bolsa de Valores de Nova Iorque (NYSE) e na Bolsa de Valores Americana (AMEX) que tinham as informações referentes ao período 1979-1983, no banco de dados COMPUSTAT, resultando em 2.398 observações. Os autores concluem que a variação nos preços dos títulos estudados é correlacionada tanto com a variação do valor adicionado quanto com a variação dos lucros. E ainda, que o modelo que combinou as duas variáveis foi o que explicou melhor o lucro da empresa.

Scherer (2006) realizou o único estudo sobre o conteúdo informacional do valor adicionado com dados brasileiros. O autor estudou a relevância da informação de valor adicionado por meio de sua associação com o preço das ações na Bolsa de Valores de São Paulo e concluiu que, para a amostra estudada (57 empresas brasileiras, no período de 2000 a 2004), a

\footnotetext{
${ }^{15}$ Lower variability and higher persistency combined with a stronger association with market-based measures of risk and a superior measure of management performance make the value-added-based accounting data potentially much more important and informative than data currently derived from accrual and cash-flow reporting. This is not to suggest that presently available accounting data should be discontinued or abandoned, but given the seemingly low cost of producing value-added information and the potentially high benefit to be derived from it, serious consideration should be given to reporting such information on a routine basis.
} 
informação de valor adicionado líquido para distribuição é relevante para os investidores dessa Bolsa.

Também com estudos empíricos, Karpik e Belkaoui (1989), Bao e Bao (1996) e RiahiBelkaoui (1999) buscaram avaliar a capacidade preditiva do valor adicionado.

O estudo de Karpik e Belkaoui (1989) buscava determinar se o valor adicionado possui maior capacidade de explicar o risco de mercado que o lucro e o fluxo de caixa. Os autores encontraram maior eficiência do valor adicionado para explicar a variabilidade do beta de mercado.

Bao e Bao (1996) testaram a capacidade preditiva em quatro variáveis do valor adicionado: líquido baseado em vendas, líquido baseado em produção, bruto baseado em vendas e bruto baseado em produção. A amostra incluiu 163 empresas norte-americanas com série temporal de 20 anos. Os resultados encontrados classificam as quatro séries estudadas como processos random walk, ou seja, os efeitos dos fatores que afetam o valor adicionado e a direção da variação não são previsíveis. Os autores afirmam que enquanto não é desenvolvida uma teoria para explicar esse comportamento, acredita-se que o contexto econômico, as políticas de negócios e as práticas contábeis sejam possíveis causas. Por fim, os autores concluem que o melhor valor para predizer o valor adicionado do próximo ano é o valor adicionado do ano corrente.

Riahi-Belkaoui (1999) estudou a capacidade preditiva do valor adicionado líquido. Esse trabalho utilizou como amostra todas as empresas com ações negociadas na Bolsa de Valores de Nova Iorque (NYSE) e na Bolsa de Valores Americana (AMEX) que tinham as informações referentes ao período 1976-1995 no banco de dados COMPUSTAT, resultando em 4.410 observações após excluir as observações extremas. Os testes empíricos mostraram que o lucro é determinado como um processo de resposta à riqueza gerada pela firma, mensurada pelo valor adicionado líquido, e um processo de ajustamento do lucro do período anterior.

Esses estudos dão indícios da superioridade do valor adicionado em relação ao lucro na precificação das ações. Entretanto, é importante ressaltar que a maior parte deles é realizada em países onde a DVA não é oficial e, portanto, não é padronizada e muitas vezes não é 
auditada. Os estudos norte-americanos usam sempre o valor adicionado calculado com base no método aditivo, ou seja, a somatória da remuneração dos fatores, com valores obtidos em outras demonstrações contábeis.

Para Morley (1979, p. 625), a maior desvantagem da DVA é a falta de padronização. Além de perder comparabilidade, isso permite que um "contador inescrupuloso" manipule a escolha de métodos de cálculo do valor adicionado para produzir os resultados desejados.

No Brasil, esse problema acabará com a regulamentação da DVA, já que ela se tornou obrigatória para as empresas de capital aberto. Entretanto, a falta de padronização em outros países limita as referências para comparação entre países. Como não existe a obrigatoriedade da publicação pelo IASB, nem um padrão internacional para a demonstração, a comparabilidade fica prejudicada.

Há muitas divergências na apresentação da DVA. A começar pelo formato: tabelas, gráficos e figuras já representaram a demonstração, especialmente quando sua evidenciação está no relatório social da empresa. Até o regime de apuração dos valores pode variar, pois existem algumas apuradas exclusivamente pelo regime de caixa, outras exclusivamente pelo regime de competência e até algumas que misturam informações de caixa com informações por competência. E o mais comum é a divergência de conteúdo, muitas já colocadas ao longo deste capítulo: alocação da depreciação, doações para comunidade como distribuição de valor, distribuição para o governo separada ou não por esferas de governo e até pesquisa e desenvolvimento como distribuição de valor adicionado (OLIVEIRA, 2008). Há claramente muitos usos diferentes para "valor adicionado" (BURCHELL; CLUBB; HOPWOOD, 1985, p. 388).

Na visão de Van Staden (2000, p. 5), a DVA vem perdendo credibilidade por ser um veículo ideal para mudar percepções sobre a empresa, pois a demonstração não é regulada e normalmente não é auditada, permitindo que os administradores a utilizem como meio de condicionar as expectativas dos usuários. Van Staden é um autor que pesquisou muito a África do Sul e atualmente é professor na Nova Zelândia. Apesar de a situação da África do Sul ter semelhanças com o Brasil (muitas empresas de capital aberto divulgando a informação voluntariamente e estudos desenvolvidos sobre a utilidade da informação para o mercado de capitais), essa crítica não é aplicável aqui com tamanha propriedade. Isso porque o modelo 
FIPECAFI, grande responsável pela divulgação voluntária no país conforme já citado, "amarra" a DVA à DRE, portanto, mesmo quando a DVA não era auditada (e muitas vezes era), era possível reconciliá-la com as informações da DRE e esta sempre foi auditada. Entretanto, na visão de Pong e Mitchell (2005, p. 177), a forma de mensuração do valor adicionado incorpora muitas das fraquezas da contabilidade financeira, já que a DVA é derivada das contas de resultado. No Brasil, essa crítica de falta de padronização é aplicável ao restante do Balanço Social que, exceto pelo modelo Ibase, ainda está longe de ser padronizado.

Burchell, Clubb e Hopwood (1985, p. 388-389) argumentam que a DVA não pode ser tratada como um instrumento de transformação social somente porque os diferentes stakeholders são tratados da mesma maneira em sua estrutura. A DVA "parece contribuir para confusão, dúvida e desconfiança". O texto justifica a afirmação pela diversidade de conceitos de valor adicionado que foram criados. E com a profusão da adoção do valor adicionado como medida de remuneração no Reino Unido, no final da década de 1970, o conceito de valor adicionado passa a ter um papel muito importante. Muitos conceitos de valor adicionado implicam em diferentes conceitos de produtividade e eficiência, portanto, insatisfação do empregado. Com isso a harmonia social pode não ser consequência do valor adicionado da maneira como ele foi constituído.

Uma das desvantagens atribuídas à DVA é a pequena quantidade, ou até a falta, de informações adicionais. Os estudos de Van Staden (1998, 2000 e 2003) argumentam que a DVA oferece apenas uma informação adicional: gasto total com salários e encargos. O último argumenta que, com a adoção das normas internacionais, essa informação passa a ser obrigatória pelo IAS 1, como já comentado neste trabalho, e a DVA perde essa única informação adicional (2003, p. 227). Pong e Mitchell (2005, p. 195) dizem que a DVA pode ser vista como "tecnicamente redundante", já que o usuário pode obter as informações evidenciadas na demonstração no restante do relatório anual.

Entretanto, essa não é a situação da DVA no Brasil. Além do gasto total com empregados e depreciação, que passa a ter evidenciação obrigatória com a adoção das normas internacionais, um grande diferencial é o valor apurado de impostos durante o período. O total distribuído ao governo, que pode ser qualificado com a carga tributária total da empresa, só é informado por meio da DVA. Devido aos impostos de valor agregado, as outras 
demonstrações não mostram essa informação porque apresentam os impostos sobre a venda, e o imposto deduzido pela compra de materiais não aparece.

\begin{abstract}
Uma das vantagens proporcionadas pelas informações apuradas na Demonstração do Valor Adicionado é a possibilidade de obter-se em um único item todos os encargos com impostos, taxas e contribuições suportados pela empresa. Em nenhuma outra demonstração contábil há essa segregação de encargos. Na demonstração do resultado do exercício, além de figurarem em itens específicos, como impostos sobre vendas e provisão para imposto de renda, os encargos com impostos, taxas e contribuições podem estar incluídos em diversos outros itens da demonstração, como, por exemplo, nas despesas de vendas, nas despesas administrativas, nos resultados financeiros e até mesmo, em determinadas situações, no custo dos produtos vendidos. Ao agrupar os encargos de natureza tributária, a DVA torna possível avaliar quantitativa e qualitativamente a respectiva carga tributária suportada pela empresa, bem como permite uma comparação imediata com outras empresas do mesmo setor, ou entre setores distintos, relativamente a essa carga. (SANTOS e HASHIMOTO, 2003, p. 154)
\end{abstract}

As duas últimas desvantagens expostas por Morley (1979, p. 624) são os custos extras gerados pela elaboração da DVA e sua publicação com o relatório anual e a confusão que a DVA pode gerar por levar os administradores a buscar a maximização do valor adicionado e não a maximização do lucro, conduzindo a decisões erradas e podendo causar prejuízos aos acionistas.

Van Staden (1998, p. 57) constata que o baixo índice de utilização da DVA pelos usuários da informação contábil na África do Sul deve-se ao receio de usar informações de divulgação voluntária e ao baixo volume de informações adicionais em relação às informações já divulgadas no Balanço Patrimonial e na DRE. Van Staden (2000, p. 9) complementa que a DVA introduz uma nova perspectiva do desempenho da empresa, não um grande volume de novas informações.

Picur (2007) realizou um estudo experimental para examinar se o nível de conhecimento em contabilidade está associado à tendência do decisor de não utilizar a informação de valor adicionado nas decisões envolvendo mensuração e distribuição de riqueza. A pesquisa constatou menor grau de utilização da informação de valor adicionado para maiores graus de conhecimentos contábeis, pois os pesquisados com maior nível de conhecimento contábil preferem usar o lucro para tomar decisões envolvendo mensuração e distribuição de riqueza.

Evraert e Riahi-Belkaoui (1998) estudaram as vantagens e desvantagens da DVA por meio de pesquisa bibliográfica e listaram as vantagens e as limitações da demonstração, citadas com 
mais frequência. Muitos dos resultados já foram abordados neste capítulo. O Quadro 8 mostra uma síntese dos resultados.

\begin{tabular}{|c|c|}
\hline Vantagens & Limitações \\
\hline $\begin{array}{l}\text { Evidencia a contribuição dos empregados para o } \\
\text { resultado final da empresa. } \\
\text { Fornece um bom indicador de produtividade para o } \\
\text { pagamento de bônus. }\end{array}$ & $\begin{array}{l}\text { Falsas Suposições - (a) uma empresa é um time } \\
\text { de grupos que cooperam, (b) o governo é } \\
\text { considerado um grupo legítimo, (c) todos os } \\
\text { grupos legítimos foram incluídos. }\end{array}$ \\
\hline $\begin{array}{l}\text { O valor adicionado pode ser mais útil na previsão de } \\
\text { eventos econômicos importantes para a empresa. } \\
\text { A DVA é congruente com os conceitos de produto } \\
\text { nacional da macroeconomia. }\end{array}$ & $\begin{array}{l}\text { Possível confusão - DVA pode causar confusão, } \\
\text { especialmente quando o valor adicionado } \\
\text { aumenta enquanto o lucro ou um componente do } \\
\text { VA decresce. }\end{array}$ \\
\hline 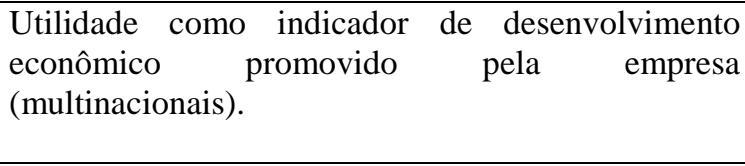 & $\begin{array}{l}\text { Possível desvio na missão do gestor }- \text { a inclusão } \\
\text { da DVA pode levar o administrador a, } \\
\text { erroneamente, perseguir maximização do valor } \\
\text { adicionado da empresa. }\end{array}$ \\
\hline $\begin{array}{l}\text { Valor adicionado funciona como uma } \\
\text { de tamanho da empresa que vendas ou }\end{array}$ & \multirow{5}{*}{$\begin{array}{l}\text { Falácias - uma interpretação errônea da DVA } \\
\text { pode criar } 5 \text { falácias: } \\
\text { a. Aumento de VA gera aumento do lucro; } \\
\text { b. Aumento de VA / trabalhador gera benefícios } \\
\text { para o acionista; } \\
\text { c. Identificar distribuição equitativa de variações } \\
\text { no valor adicionado; } \\
\text { d. Um VA / trabalhador relativamente alto } \\
\text { representa melhor desempenho econômico; } \\
\text { e. Maior distribuição de VA para os empregados } \\
\text { não implica em aumento de salário. }\end{array}$} \\
\hline $\begin{array}{l}\text { Valor adicionado tem maior poder preditivo para } \\
\text { lucros, retorno esperado e risco (Maunders, 1985). }\end{array}$ & \\
\hline $\begin{array}{l}\text { DVA é mais útil para os representantes de classe } \\
\text { negociarem condições de trabalho. }\end{array}$ & \\
\hline $\begin{array}{l}\text { VA é melhor indicador de desempenho que lucro } \\
\text { líquido. }\end{array}$ & \\
\hline $\begin{array}{l}\text { Fornece um bom indicador de eficiência de gestão e } \\
\text { de integração vertical. }\end{array}$ & \\
\hline
\end{tabular}

FONTE: Baseado em EVRAERT; RIAHI-BELKAOUI (1998)

Tanto na abordagem normativa de maximização dos lucros como o principal objetivo da organização como na abordagem positiva da utilidade da informação para a tomada de decisão financeira, as demonstrações contábeis têm como principal objetivo atender às necessidades dos investidores, ou seja, acionistas e credores (VAN STADEN, 2000, p. 9). As normas internacionais de contabilidade sustentam essa mesma visão (Framework e IAS 1), e os demais stakeholders acabam sendo desconsiderados.

A empresa não pode ser objeto de análise pela contabilidade apenas do ponto de vista dos seus acionistas, dos seus credores e dos seus administradores. A amplitude e a diversidade de atividades e de relacionamentos que a empresa é obrigada a manter, ainda que sob a justificativa de que são meios para atingir os objetivos dos acionistas, necessitam também ser objeto de estudo da contabilidade, levando em consideração os interesses que outras pessoas têm sobre a empresa. Nesse contexto, desloca-se a visão da contabilidade como instrumento a serviço daqueles que investiram no negócio (os acionistas ou stockholders) para uma nova ótica, em que a contabilidade é utilizada como ferramenta útil aos que têm interesses de natureza diversa no mesmo negócio (stakeholders). (SANTOS e HASHIMOTO, 2003, p. 154). 
A contabilidade é uma disciplina social e técnica, e a interação desses dois aspectos é relevante para explicar a mudança (ou a ausência de mudança) nas práticas contábeis. A mudança contábil depende de fatores externos e internos da empresa. Investigar como suas combinações levam a diferentes resultados ajuda a elucidar o processo de desenvolvimento da disciplina contábil (PONG; MITCHELL, 2005, p. 183/193).

A instituição da DVA no Brasil é um fato, uma mudança em fase de consolidação. Conforme estudado neste capítulo, essa mudança deverá trazer bons resultados para a contabilidade. Entretanto, é importante assegurar que as vantagens, como a interface inteligível e a abordagem dos stakeholders, mantenham-se como vantagens, mesmo que problemas políticos aconteçam como ocorreu no Reino Unido. E as desvantagens sejam superadas, como a questão da padronização e da comparabilidade com o resto do mundo (será um desafio para o Brasil, a partir do próximo ano, mostrar a importância da DVA para o IASB), a disputa pela maior fatia da remuneração e o pequeno, ainda que consistente, volume de informações adicionais.

Considerando o caráter social da demonstração em estudo, os investimentos sociais podem ser adicionados como uma informação (seja como redução ou como distribuição de valor adicionado) diferenciada da demonstração. Será uma demonstração auditada, portanto, os gastos com responsabilidade social também serão e isso dará mais força para o desenvolvimento do Balanço Social no Brasil. 


\section{INVESTIMENTOS SOCIOAMBIENTAIS}

O objetivo deste capítulo é analisar os investimentos sociais realizados pelas empresas. O Instituto de Pesquisa Econômica Aplicada (IPEA), por sua Diretoria de Estudos Sociais (DISOC), vem pesquisando, desde 1999, as ações sociais realizadas pelas empresas em caráter voluntário. É uma pesquisa pioneira sobre os investimentos sociais privados. Já foram concluídas duas edições nacionais, referentes aos anos 2000 e 2004. O conceito utilizado pela pesquisa para definir ação social empresarial foi amplo, tendo sido considerada qualquer atividade que as empresas realizaram, em caráter voluntário, para o atendimento de comunidades nas áreas de assistência social, alimentação, saúde, educação, entre outras. Essas atividades incluem desde pequenas doações eventuais a pessoas ou instituições até grandes projetos mais estruturados (IPEA/DISOC, 2006, p. 4).

A amostra de empresas pesquisadas (mais de 9.000 em cada edição) é estatisticamente significativa e permite a generalização dos resultados para todo o Brasil. Foram pesquisadas empresas de diferentes portes, localizações e atividades econômicas. Na pesquisa de 2004, estão na região Sudeste $48 \%$ das empresas e $71 \%$ delas têm apenas de 1 a 10 empregados. A pesquisa mostrou um crescimento na proporção de empresas que declararam realizar algum tipo de ação social para a comunidade, passando de 59\%, em 2000, para 69\%, em 2004. As empresas de grande porte são aquelas com maior participação em ações sociais, mas foram as que tiveram menor crescimento no período, apenas 6\%, mesmo aumento observado nas empresas de pequeno porte. Esse crescimento foi mais expressivo nas microempresas, $12 \%$, e nas empresas de médio porte, 19\% (IPEA/DISOC, 2006).

Essa pesquisa do IPEA/DISOC dá os primeiros indícios do que deve ser observado no estudo empírico. O Gráfico 2 mostra os tipos de investimentos constatados. Destacam-se as ações relacionadas com Assistência Social e com Alimentação e Abastecimento, que receberam mais investimentos. A pesquisa aponta ainda a preferência por ações relacionadas a crianças (62\%, em 2004) e idosos (39\%, em 2004). 


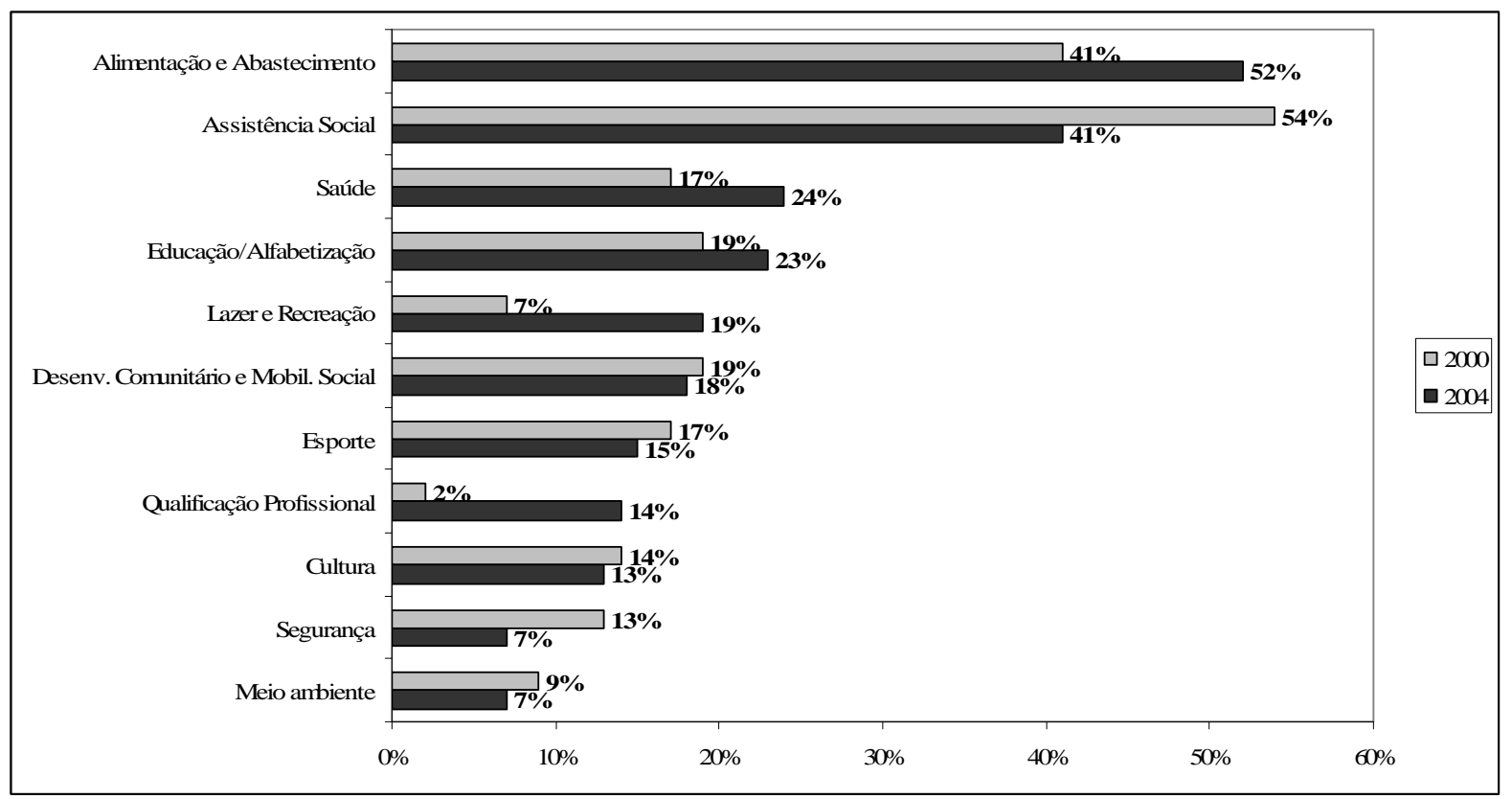

Gráfico 2 - Gráfico das atividades que receberam ações sociais das empresas

FONTE: Pesquisa Ação Social das Empresas no Brasil (IPEA/DISOC, 2006, p. 21)

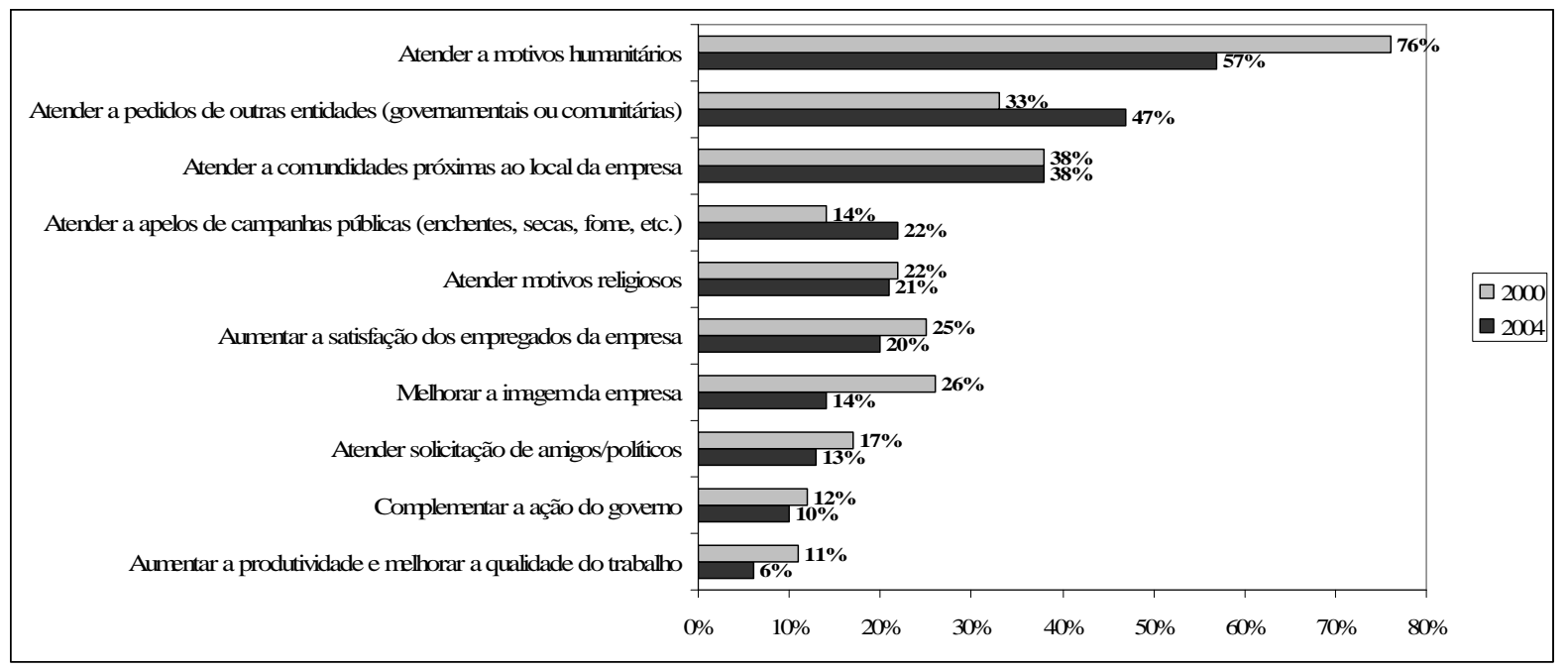

Gráfico 3 - Gráfico dos motivos pelos quais as empresas realizaram ações sociais FONTE: Pesquisa Ação Social das Empresas no Brasil (IPEA/DISOC, 2006, p. 23)

A pesquisa preocupou-se também em saber o motivo que leva as empresas a investirem em ações sociais (Gráfico 3). A questão permitia marcar mais de uma alternativa, e mais da metade das empresas respondeu realizar ações sociais por motivos humanitários. Vale notar que as motivações relacionadas a ganhos da empresa (aumentar a satisfação dos empregados, melhorar a imagem e aumentar a produtividade) apresentaram quedas. Entretanto, em 2006, $63 \%$ das empresas alegam que realizar ações sociais faz parte da estratégia da empresa. 
Por fim, é interessante observar o recuo acentuado do percentual de empresas que realizam ações sociais com o objetivo de melhorar sua imagem: enquanto em 2000, 26\% das empresas atuava com essa motivação, em 2004, a proporção cai pela metade. Esse resultado pode estar refletindo o aumento da participação das micro-empresas. Em geral, elas atuam de maneira mais eventual e preocupam-se menos com a imagem. Outra hipótese é de que, no final dos anos de 1990, a preservação da imagem foi mais vezes associada às relações de boa vizinhança do que a uma imagem pública voltada para diferenciar e prestigiar a empresa. A entrada maciça de novas empresas no campo social parece ter decorrido de convicções pessoais dos dirigentes empresariais (filantrópicas e religiosas) associadas a demandas externas às empresas, tanto por parte das entidades que executam projetos sociais como por parte do poder público. (IPEA/DISOC, 2006, p. 23).

O aumento de empresas agindo em resposta à demanda de outras entidades é compatível com a frequência de suas ações sociais. Em 2004, $41 \%$ das empresas declararam realizar ações sociais habitualmente e 40\%, eventualmente (19\% não responderam), enquanto, em 2000, essas proporções eram 58\% e $41 \%$ respectivamente (7\% não responderam). Possivelmente, essa variação, conforme a pesquisa, deve-se "à maior presença de micro-empresas que, no geral, desenvolvem ações de caráter mais emergencial e, portanto, com menor regularidade do que as maiores" (IPEA/DISOC, 2006, p. 24).

Por fim, é necessário entender como as empresas realizam os investimentos. O "como" aqui se refere à maneira como a empresa entrega recursos para a causa social. Isso é importante para a análise do valor adicionado, sob a ótica do cálculo do PIB.

Em geral, as empresas realizam suas atividades sociais por meio de doações simultâneas de recursos, quer para pessoas ou comunidades carentes (54\%), quer para organizações que executam projetos sociais $(67 \%)$. No entanto, no período analisado, cresce a proporção de empresas que apóia organizações (comunitárias, filantrópicas ou religiosas), consolidando-se como o principal mecanismo de atuação das empresas privadas na área social. O percentual de empresas que informa doar recursos diretamente para pessoas ou comunidades carentes é alto e mantém-se estável ao longo dos anos. Por outro lado, apenas 3\% das empresas atuou, em 2004, por meio da criação e desenvolvimento de seus próprios projetos. (IPEA/DISOC, 2006, p. 24).

Os investimentos sociais privados recebem incentivos do governo por meio de benefícios tributários. Investimentos sociais que fomentem o esporte, a cultura, os direitos das crianças e adolescentes e atividades audiovisuais podem ser deduzidos do imposto de renda devido até o limite imposto pelo Regulamento do Imposto de Renda. Esses limites variam de 1 a $4 \%$ do imposto devido, conforme a atividade incentivada. $\mathrm{O}$ incentivo não é válido para a parcela adicional do imposto de renda (CRC-SP/FIESP/FACESP, 2002, p. 11).

Entretanto, o investimento social privado é pouco influenciado pela política de benefícios tributários. A proporção de empresários que se utilizava dos benefícios fiscais em 2000 era de 
apenas $6 \%$ e, em 2004, essa proporção caiu para 2\% das empresas que atuaram no social. Este comportamento, porém, é diferenciado segundo o porte da empresa. Nas empresas menores (até 10 empregados), em 2004, o uso desses benefícios atingia apenas 0,7\% das empresas, enquanto, entre aquelas com mais de 500 empregados, a proporção era de 17\%. Esse resultado confirma que o envolvimento social do setor privado ocorre independentemente do Estado: trata-se de uma forma de intervenção das próprias empresas que não reconhecem influências do governo no processo de sua atuação (IPEA/DISOC, 2006, p. 18).

A pesquisa realizada pelo IPEA é ampla e traz informações importantes para a análise dos investimentos sociais sob a ótica do valor adicionado. Mas a grande maioria das empresas entrevistadas não está sujeita à publicação da DVA. Logo, optou-se por realizar uma análise específica de empresas que estão obrigadas a publicar a DVA no Brasil.

\subsection{Estudo Empírico: Metodologia}

O objetivo desta etapa é identificar uma lista de categorias de investimentos sociais diferentes realizados pelas empresas para posterior verificação de como elas se relacionam com valor adicionado. Não existe a pretensão de avaliar os resultados desses investimentos sociais, o objetivo é identificar quais são as ações sociais praticadas e qual a estratégia de transferência dos recursos.

A estratégia de coleta de dados escolhida foi análise de conteúdo qualitativa dos relatórios de sustentabilidade publicados por uma amostra de empresas. A análise de conteúdo é uma técnica de análise das comunicações. "É uma técnica para se estudar e analisar a comunicação de maneira objetiva e sistemática. Buscam-se inferências confiáveis de dados e informações com respeito a determinado contexto, a partir dos discursos escritos e orais [...]" (MARTINS; THEÓPHILO, 2007, p. 95).

Bardin $(2004$, p. 107) reforça a validade da técnica na elaboração das deduções específicas sobre um acontecimento, isto é, os resultados da análise de conteúdo qualitativa são mais eficientes em inferências específicas, não gerais. Além disso, a técnica é eficiente para 
pequenos conjuntos de documentos e para estabelecimento de categorias mais discriminadas. Daí a adequação da ferramenta a este trabalho.

Richardson (1999, p. 223) coloca os requisitos que as categorias devem cumprir: (i) homogeneidade, ou seja, não misturar critérios de classificação; (ii) exaustividade, refere-se à necessidade de classificar todo o texto; (iii) exclusão, pois um mesmo elemento do conteúdo não pode ser classificado em mais de uma categoria; e (iv) objetividade, porque pesquisadores diferentes devem chegar aos mesmos resultados.

A análise de conteúdo pode ser organizada em três fases: pré-análise; exploração do material; e tratamento dos resultados. A primeira delas, pré-análise, é a fase da organização, aquela com o objetivo de tornar operacionais e sistematizar as ideias iniciais. Não obstante compreenda um "período de intuições", conduz a um plano de análise com um esquema preciso do desenvolvimento das etapas. A segunda fase consiste em codificar (se for o caso) e classificar os dados. Por fim, o tratamento dos resultados é a fase em que se buscam conclusões, inferências a respeito do tema estudado (BARDIN, 2004, p. 89-95).

Assim, na etapa de pré-análise deste estudo, constatou-se que o documento mais adequado a ser analisado é o Balanço Social da empresa, às vezes chamado Relatório de Sustentabilidade. Apesar das limitações apresentadas por esse tipo de documento, é a ferramenta mais adequada para atingir o objetivo proposto, pois é o único que declara todas as ações sociais realizadas. Entre as limitações, inclui-se a possibilidade de o relatório não ser auditado, o que reduz a confiabilidade da informação, e o fato de não haver um padrão de relatório amplamente adotado, o que prejudica a comparabilidade da informação. Decidiu-se que o ano de referência dos relatórios seria 2007 pela disponibilidade dos dados.

Além disso, ainda nessa fase, foi desenvolvido o roteiro da análise de conteúdo (Apêndice 1). $\mathrm{O}$ roteiro foi dividido em três partes, sendo as duas primeiras com informações de descrição da empresa e características do relatório. A terceira e mais importante traz a análise a ser usada para atingir o objetivo proposto. Optou-se por dividir essa parte em outras duas conforme o envolvimento de interpretação por parte do pesquisador. Por se tratar de uma pesquisa qualitativa, em alguns momentos será inevitável que o analista faça interpretações das informações evidenciadas, então, optou-se por deixar claro quando isso pode acontecer e por separar tal análise na etapa de avaliação dos resultados. Assim, o roteiro divide-se em: 
A. informações sobre a empresa (questões A.1 a A.6);

B. informações sobre a estrutura do relatório (B.1 a B.8);

C. informações divulgadas pela empresa no relatório com as subdivisões:

I. critérios que não envolvem julgamento do pesquisador (C.1 a C.6) e

II. critérios que envolvem julgamento do pesquisador (C.7 a C.11).

O roteiro desenvolvido sugere uma categorização prévia dos investimentos sociais. O roteiro foi, em sua maioria, baseado em Gray, Kouhy e Lavers (1995b) e teve influência também de Macke e Carrion (2006); Sousa Filho e Wanderley (2006); Rover, Múrcia e Borba (2008) e IPEA/DISOC (2006). Os trabalhos de Gray, Kouhy e Lavaers (1995a e 1995b) formaram a base de sustentação do estudo empírico porque eles fizeram um amplo estudo sobre a divulgação de informações socioambientais no Reino Unido, no período de 1979 a 1991. Na metodologia utilizada para coleta de dados, os autores usam análise de conteúdo e investigam as práticas sociais das empresas, por isso boa parte da metodologia é replicada neste trabalho. Além de uma lista ampla das possibilidades de investimentos sociais, os autores classificam a informação fornecida conforme a notícia que ela traz (boa, ruim ou neutra), conforme a característica qualitativa (descritiva, quantitativa financeira ou quantitativa não financeira) e conforme a possibilidade de verificação (auditável ou não).

As instruções colocadas entre colchetes no roteiro (Apêndice 1) visam a conferir confiabilidade ao instrumento de coleta de dados. A unidade de análise selecionada foi o parágrafo, isto é, cada parágrafo (as tabelas e gráficos serão avaliados como parágrafos) será analisado pelo roteiro desenvolvido.

O instrumento de análise de conteúdo foi testado com o Relatório de Sustentabilidade 2007 do Banco Bradesco e com o Balanço Social da Companhia de Bebidas Ipiranga. O pré-teste foi importante para realizar algumas adaptações no instrumento de coleta de dados. Após os ajustes, foi realizada verificação de confiabilidade do instrumento. Para isso, o relatório do Bradesco foi novamente avaliado, desta vez, por dois pesquisadores diferentes e houve homogeneidade em $92,6 \%$ das informações coletadas. As diferenças concentraram-se em três quesitos: quanto ao relacionamento da atividade com o processo produtivo (item C.7 do roteiro), quanto à "notícia" divulgada pela informação, boa, neutra ou ruim (C.8) e quanto à possibilidade de auditar a informação (C.10), todos do grupo de quesitos que envolvem 
julgamento do pesquisador. Com isso, o roteiro foi considerado apto para coleta de dados, com as devidas ressalvas na análise das questões que envolvem julgamento (C. 7 a C.11).

Quanto à amostra, optou-se por amostra intencional, logo não aleatória. O objetivo desta pesquisa empírica é categorizar os investimentos sociais, portanto, era importante buscar diversidade na amostra. A amostra intencional permite a escolha de empresas diferentes em vários aspectos e é possível abranger uma maior variedade de ações de RSC. Foram definidos alguns aspectos nos quais a amostra deveria apresentar diversidade:

1. atividade econômica, conforme classificação setorial no anuário EXAME Melhores e Maiores 2008;

2. tamanho, conforme classificação das maiores no anuário EXAME Melhores e Maiores 2008 ;

3. representatividade no setor, conforme classificação das melhores no anuário EXAME Melhores e Maiores 2008;

4. nível de governança corporativa, conforme classificação nos níveis diferenciados da Bolsa de Valores de São Paulo (Bovespa);

5. risco ambiental, conforme Lei Federal n. ${ }^{\circ} 10.165 / 00$ que classifica atividades por seu potencial de poluição e uso de recursos ambientais em pequeno, médio e alto;

6. participação no Índice de Sustentabilidade Empresarial (ISE) desenvolvido pela Bovespa;

7. classificação no anuário EXAME Melhores empresas para trabalhar $2008 \mathrm{e}$

8. classificação no anuário Guia EXAME de sustentabilidade 2008.

Em seguida, ficou definido que apenas as empresas de capital aberto entrariam na amostra, pois a Lei n. ${ }^{\circ} 11.638 / 07$ tornou a DVA obrigatória somente para essa categoria de empresas. Além disso, as empresas de capital aberto, por serem mais vulneráveis ao julgamento dos investidores, em geral, são mais transparentes, o que pode amenizar a questão da confiabilidade dos relatórios sociais.

Inicialmente, a amostra foi definida em 19 empresas, uma de cada atividade econômica, conforme classificação do anuário EXAME Melhores e Maiores 2008. Entretanto, em quatro setores, não foi possível encontrar empresa de capital aberto com o Relatório de Sustentabilidade (ou Relatório Social) divulgado no endereço eletrônico da companhia. São eles: Atacado, Bens de Capital, Farmacêutico e Indústria Digital. 
Além das 15 empresas já definidas, foram incluídas na amostra empresas premiadas por seu Relatório Social ou por informações de Responsabilidade Social. Foram elas: Natura, destaque do Guia EXAME de Sustentabilidade 2008; CPFL, premiada em 2008 pela Associação Brasileira de Distribuidores de Energia Elétrica (ABRADEE) na categoria Responsabilidade Social e Elektro que recebeu da Associação Brasileira das Companhias Abertas (ABRASCA), em 2008, menção honrosa pelos aspectos socioambientais do Relatório Anual. Também foi incluída a Petrobras por ser a maior empresa brasileira conforme anuário EXAME Melhores e Maiores 2008. Vale ressaltar que todos os prêmios e periódico citados referem-se à atuação da empresa em 2007 ou ao seu relatório sobre o ano 2007.

A Lei n. ${ }^{\circ} 10.165 / 00$ analisa os impactos ambientais das atividades econômicas, mas não analisa os impactos sociais. Então, optou-se por incluir empresas com impacto social negativo para garantir a diversificação da amostra. Como não seria possível avaliar as condições de trabalho na companhia, foi escolhida uma atividade econômica reconhecida pelos danos sociais, e a Souza Cruz, companhia de cigarros, entrou na amostra.

Por fim, como o setor de serviços na classificação adotada apresentava grande diversidade, optou-se por incluir mais empresas dessa atividade. Foram incluídas as companhias Anhanguera Educacional e a Sabesp, além da CCR Rodovias que já estava classificada no setor. Com isso, a amostra ficou definida com 22 empresas (Tabela 6).

Em três casos, conforme Tabela 6, foi utilizado o Relatório Anual da empresa ao invés do Relatório Social ou de Sustentabilidade. Em todos os casos, a empresa anunciava explicitamente em seu endereço eletrônico que o Relatório de Sustentabilidade estava incluído no relatório anual, por isso optou-se por utilizá-los. Na análise de conteúdo desses documentos, as demonstrações contábeis junto com suas notas explicativas foram classificadas como um único parágrafo.

Além disso, em outros três casos não foi possível analisar o relatório de 2007. Duas empresas só divulgavam o relatório bianual (2007/2008), Souza Cruz e Whirlpool, e optou-se por utilizá-los. O terceiro caso, o grupo Pão de Açúcar, só disponibilizou o Relatório 2008. Houve tentativa de contato com a empresa para ter acesso ao Relatório 2007, mas sem sucesso. Então, para não ficar com mais um setor sem representação na amostra, definiu-se pela utilização do relatório. 
Tabela 6 - Caracterização da amostra de empresas analisadas no estudo empírico

\begin{tabular}{|c|c|c|c|c|c|c|c|c|}
\hline Empresa & Setor & $\begin{array}{c}\text { Classificação } \\
\text { Maiores }\end{array}$ & $\begin{array}{l}\text { Classificação } \\
\text { Melhores (no } \\
\text { setor) }\end{array}$ & ISE & $\begin{array}{l}\text { Governança } \\
\text { Corporativa }\end{array}$ & $\begin{array}{l}\text { Risco da } \\
\text { atividade }\end{array}$ & $\begin{array}{c}\text { Melhores } \\
\text { para } \\
\text { Trabalhar }\end{array}$ & $\begin{array}{c}\text { Melhores } \\
\text { Sustentabili- } \\
\text { dade }\end{array}$ \\
\hline$\overline{\text { AES Tietê }}$ & Energia & 244 & 1 & $\operatorname{sim}$ & - & Médio & $\operatorname{sim}$ & $\operatorname{sim}$ \\
\hline Ambev & Bens de Consumo & 4 & 8 & $\operatorname{sim}$ & - & Médio & $\operatorname{sim}$ & não \\
\hline Anhanguera Educ & Serviços & Não Consta & 1 & não & $\mathrm{N} 2$ & Não Consta & não & não \\
\hline Bradesco ${ }^{1}$ & Instituições Financeiras & $* *$ & $* *$ & $\operatorname{sim}$ & N1 & Não Consta & $\operatorname{sim}$ & $\operatorname{sim}$ \\
\hline Braskem & Química e Petroquímica & 13 & 12 & $\operatorname{sim}$ & N1 & Alto & não & não \\
\hline CCR Rodovias & Serviços & Não Consta & Não Consta & $\operatorname{sim}$ & NM & Não Consta & não & não \\
\hline Celulose Irani & Papel e Celulose & 686 & 8 & não & - & Alto & não & não \\
\hline $\mathrm{CPFL}^{2}$ & Energia & 48 & 2 & $\operatorname{sim}$ & NM & Médio & $\operatorname{sim}$ & $\operatorname{sim}$ \\
\hline СТВC & Telecomunicações & 380 & 12 & não & - & Não Consta & não & não \\
\hline Duratex ${ }^{2}$ & Indústria da Construção & 177 & 3 & $\operatorname{sim}$ & N1 & Médio & não & não \\
\hline Elektro & Energia & 94 & Não Consta & não & - & Médio & não & $\operatorname{sim}$ \\
\hline Gol & Transporte & 71 & 12 & $\operatorname{sim}$ & N2 & Não Consta & não & não \\
\hline Karsten & Têxteis & 921 & 11 & não & - & Médio & não & não \\
\hline Metal Leve (Mahle) & Auto-industria & 210 & Não Consta & não & - & Médio & não & não \\
\hline Natura ${ }^{2}$ & Bens de Consumo & 82 & 1 & $\operatorname{sim}$ & NM & Alto & não & $\operatorname{sim}$ \\
\hline Pão de Açúcar ${ }^{3}$ & Varejo & 17 & 11 & não & N1 & Não Consta & não & não \\
\hline Petrobras & Química e Petroquímica & 1 & 5 & $\operatorname{sim}$ & - & Alto & não & não \\
\hline Sabesp & Serviços & 50 & 11 & $\operatorname{sim}$ & NM & Médio & não & não \\
\hline Souza Cruz ${ }^{3}$ & Bens de Consumo & 31 & 2 & $\operatorname{sim}$ & - & Médio & não & não \\
\hline Tenaris Confab ${ }^{2}$ & Siderurgia e Metalurgia & 187 & 14 & não & N1 & Alto & $\operatorname{sim}$ & não \\
\hline Vale & Mineração & 5 & 13 & $\operatorname{sim}$ & N1 & Alto & $\operatorname{sim}$ & não \\
\hline Whirlpool ${ }^{3}$ & Eletroeletrônico & 52 & 7 & não & - & Médio & $\operatorname{sim}$ & não \\
\hline $\begin{array}{l}{ }_{1} \text { Os bancos não for } \\
\text { conforme faturamen } \\
{ }^{2} \text { Relatório incluído } \\
{ }^{3} \text { Relatório 2007/20 }\end{array}$ & $\begin{array}{l}\text { classificados com as den } \\
\text { mas de acordo com o Pa } \\
\text { relatório anual. } \\
\text { Souza Cruz e Whirlpoo }\end{array}$ & $\begin{array}{l}\text { empresas no } \\
\text { ônio Líquido } \\
\text { apenas } 2008\end{array}$ & $\begin{array}{l}\text { uário EXAM } \\
\text { r isso o valor } \\
\text { ão de Acúcar }\end{array}$ & Mell & $\begin{array}{l}\text { es e Maior } \\
\text { a faturame }\end{array}$ & $\begin{array}{l}\text { Também } \\
\text { do Brade }\end{array}$ & $\overline{\text { oram c }}$ & $\begin{array}{l}\text { ificados } \\
\text { valor de }\end{array}$ \\
\hline
\end{tabular}

Após a coleta, os dados foram tabulados para análise. Foram utilizados os softwares Microsoft Excel e SPSS. A análise dos resultados será apenas descritiva, visto que o objetivo do estudo empírico é identificar as categorias dos investimentos sociais. É importante ressaltar que as informações evidenciadas nos relatórios analisados não podem ser definidas como investimentos sociais ou ambientais. São informações e nem sempre se caracterizam como investimento. Por isso, inicialmente será realizada análise das informações, isto é, das categorias em que as informações se enquadram. Em seguida, haverá a diferenciação entre as informações e as ações socioambientais.

\subsection{Estudo Empírico: Resultados}

A primeira parte do roteiro de análise de conteúdo traz informações sobre a empresa. Como a amostra é intencional, não foi possível estabelecer nenhum tipo de relação entre tamanho da empresa e qualidade do relatório, ou ainda, nacionalidade do controle e características do 
relatório. O objetivo dessa etapa é complementar a caracterização da amostra. A Tabela 7 mostra as respostas para as seguintes perguntas:

A1. Qual a nacionalidade do controle da empresa?

A2. Quantas pessoas a empresa declarou empregar no Relatório Social 2007?
a. Número de empregados
b. Número de empregados terceirizados

A3. Qual a receita líquida no ano 2007?

A4. Qual a margem líquida da empresa em 2007?

A5. Qual o valor total do ativo consolidado em 2007?

A6. Relatório Social está agregado ao Relatório Anual?

Tabela 7 - Dados de caracterização da amostra coletados na parte A do roteiro de avaliação dos relatórios

\begin{tabular}{|c|c|c|c|c|c|c|c|}
\hline \multirow{2}{*}{ Empresa } & $\overline{\mathrm{A1}}$ & A2a & A2b & $\overline{\mathrm{A3}}$ & $\overline{\mathrm{A4}}$ & A5 & $\overline{\mathrm{A6}}$ \\
\hline & Controle & $\begin{array}{c}\text { Total de } \\
\text { Empregado } \\
\mathrm{S} \\
\end{array}$ & $\begin{array}{c}\text { Empregados } \\
\text { Terceirizados }\end{array}$ & $\begin{array}{c}\text { Receita } \\
\text { Líquida (em } \\
\text { milhões R\$) }\end{array}$ & $\begin{array}{c}\text { Margem } \\
\text { Líquida }\end{array}$ & $\begin{array}{c}\text { Ativo } \\
\text { Consolidado }\end{array}$ & $\begin{array}{c}\text { Agregado } \\
\text { Relatório } \\
\text { Anual } \\
\end{array}$ \\
\hline$\overline{\text { AES Tietê }}$ & Americano & 283 & Não Declarado & $1.463,88$ & $41,61 \%$ & $2.503,45$ & Não \\
\hline Ambev & Belga & 25219 & 5113 & $19.648,2$ & $14,33 \%$ & $35.475,75$ & Não \\
\hline Anhanguera Educ & Brasileiro & 6952 & Não Declarado & 273,6 & $0,16 \%$ & 819,66 & Não \\
\hline Bradesco & Brasileiro & 82773 & 7678 & 18032,17 & $44,42 \%$ & $341.184,40$ & Não \\
\hline Braskem & Brasileiro & 3427 & 9934 & $17.679,4$ & $3,10 \%$ & $20.892,00$ & Não \\
\hline CCR Rodovias & Brasileiro & 4387 & 0 & $2.353,0$ & $24,80 \%$ & $4.228,70$ & Não \\
\hline Celulose Irani & Brasileiro & 3187 & 1388 & 350,4 & $4,17 \%$ & 479,99 & Não \\
\hline CPFL & Brasileiro & 7176 & 5414 & $9.409,5$ & $17,47 \%$ & $15.595,77$ & Sim \\
\hline СТВC & Brasileiro & 10682 & 749 & $1.160,2$ & $2,26 \%$ & $1.271,59$ & Não \\
\hline Duratex & Brasileiro & 6785 & 114 & $1.670,6$ & $19,09 \%$ & $2.630,47$ & Sim \\
\hline Elektro & Americano & 2690 & 4382 & $2.256,1$ & $20,70 \%$ & $2.669,99$ & Não \\
\hline Gol & Brasileiro & 15722 & 6891 & $4.967,3$ & $5,41 \%$ & $5.764,83$ & Não \\
\hline Karsten & Brasileiro & 2429 & Não Declarado & 269,5 & $4,07 \%$ & 209,56 & Não \\
\hline Metal Leve (Mahle) & Alemão & 9716 & Não Declarado & $1.639,4$ & $6,48 \%$ & $1.189,30$ & Não \\
\hline Natura & Brasileiro & 5919 & 1170 & $3.072,7$ & $15,04 \%$ & $1.962,61$ & Sim \\
\hline Pão de Açúcar & anco-Brasilei & 70656 & Não Declarado & $18.033,1$ & $1,44 \%$ & $13.544,02$ & Não \\
\hline Petrobras & Estatal & 68931 & 211566 & $170.577,7$ & $12,61 \%$ & $231.227,80$ & Não \\
\hline Sabesp & Estatal & 16850 & 0 & $5.970,8$ & $17,56 \%$ & $18.663,38$ & Não \\
\hline Souza Cruz & Inglês & 7109 & 0 & $4.846,8$ & $18,74 \%$ & $3.234,26$ & Não \\
\hline Tenaris Confab & Argentino & Jão Declarad & Não Declarado & $1.808,8$ & $13,77 \%$ & $1.715,21$ & Sim \\
\hline Vale & Brasileiro & 56400 & 90400 & $64.763,5$ & $30,89 \%$ & $132.897,84$ & Não \\
\hline Whirlpool & Americano & 11930 & Não Declarado & $5.582,6$ & $8,52 \%$ & $3.818,33$ & Não \\
\hline
\end{tabular}

A Tabela 8 traz a segunda parte do roteiro de análise de conteúdo. O objetivo é caracterizar os relatórios analisados. As questões respondidas nesta etapa foram:

B1. O Relatório divulga o modelo Ibase de Balanço Social?

B2. O Relatório segue os padrões GRI de Balanço Social?

B3. Qual o nível de aderência ao GRI declarado no relatório?

B4. Relatório Social foi auditado? 
B5. O Relatório está estruturado conforme as quatro vertentes do Balanço Social?

B6. Qual o número de páginas do Relatório analisado?

B7. Qual o número de parágrafos analisados no Relatório?

Tabela 8 - Dados de caracterização da amostra coletados na parte B do roteiro de avaliação dos relatórios

\begin{tabular}{lc|c|c|c|c|c|c}
\hline \multirow{1}{*}{ Empresa } & B1 & B2 & B3 & B4 & B5 & B6 & B7 \\
\cline { 2 - 8 } AES Tietê & Ibase? & GRI? & Aderência GRI & Auditado? & $\begin{array}{c}\text { Quatro } \\
\text { vertentes? }\end{array}$ & $\begin{array}{c}\text { Número de } \\
\text { Páginas }\end{array}$ & $\begin{array}{c}\text { Número de } \\
\text { Parágrafos }\end{array}$ \\
\cline { 2 - 8 } Ambev & Sim & Sim & C & Não & Não & 107 & 255 \\
Anhanguera Educ & Não & Sim & B & Não & Exceto DVA & 47 & 248 \\
Bradesco & Não & Não & - & Não & Não & 140 & 321 \\
Braskem & Sim & Sim & A+ & Sim & Não & 103 & 371 \\
CCR Rodovias & Sim & Não & - & Não & Não & 40 & 102 \\
Celulose Irani & Sim & Sim & B & Não & Não & 145 & 397 \\
CPFL & Não & Sim & B+ & Sim & Não & 83 & 382 \\
CTBC & Sim & Sim & A & Não & Não & 118 & 380 \\
Duratex & Sim & Sim & C & Não & Não & 65 & 212 \\
Elektro & Sim & Sim & C & Não & Não & 77 & 284 \\
Gol & Sim & Sim & B & Não & Não & 166 & 362 \\
Karsten & Sim & Não & - & Não & Sim & 38 & 106 \\
Metal Leve (Mahle) & Sim & Não & - & Não & Sim & 16 & 74 \\
Natura & Não & Não & - & Não & Não & 28 & 142 \\
Pão de Açúcar & Não & Sim & A+ & Sim & Não & 80 & 289 \\
Petrobras & Sim & Sim & C & Não & Não & 74 & 249 \\
Sabesp & Sim & Sim & A+ & Sim & Não & 118 & 475 \\
Souza Cruz & Sim & Sim & C & Não & Não & 175 & 405 \\
Tenaris Confab & Sim & Sim & Não Declarado & Sim & Não & 80 & 426 \\
Vale & Não & Não & - & Não & Não & 84 & 166 \\
Whirlpool & Não & Sim & B+ & Sim & Não & 226 & 1009 \\
\hline & Não & Sim & B & Sim & Não & 58 & 289 \\
\hline
\end{tabular}

O Relatório Ibase é uma tabela com elaboração relativamente simples e bem divulgado pelo próprio Ibase e pelo Instituto Ethos. Antes de iniciar a coleta, a expectativa era que $100 \%$ das empresas divulgassem esse relatório. Entretanto, 36\% dos relatórios analisados não incluíam o modelo Ibase. Não foi verificado se todas as informações do Ibase estavam dispersas ao longo desses relatórios.

Já o modelo GRI de relatório, um modelo complexo com volumoso número de indicadores, foi publicado por $73 \%$ da amostra. Apesar de apenas quatro empresas, $18 \%$ do total da amostra, apresentarem nível A de aderência (representa apresentar todos os indicadores sugeridos - são 70 indicadores essenciais além dos indicadores setoriais), o volume de empresas seguindo o modelo GRI superou a expectativa inicial desta pesquisa. Isso pode indicar que as empresas estão buscando melhorar o detalhamento dos relatórios sociais. Entretanto, também pode indicar que as empresas usam o modelo GRI como um guia para a construção dos relatórios, mas divulgam somente os indicadores que lhes são convenientes. Esta segunda hipótese é fortalecida pela análise dos relatórios, pois apenas 5\% dos parágrafos 
analisados, nas categorias Recursos Humanos, Meio Ambiente e Comunidade, foram classificados como informação ruim, contra $72 \%$ de informações boas e $23 \%$ de informações neutras.

Sobre a verificação externa dos relatórios, percebe-se que ainda não há uma tendência nesse sentido. Apenas 32\% dos relatórios apresentaram declaração de garantia das informações fornecidas. Vale ressaltar que tais declarações avaliam a exatidão e a confiabilidade das informações fornecidas pelo relatório, não os impactos das práticas da companhia. Isso destaca certa fragilidade do documento usado no estudo empírico, limitação já colocada na descrição da metodologia.

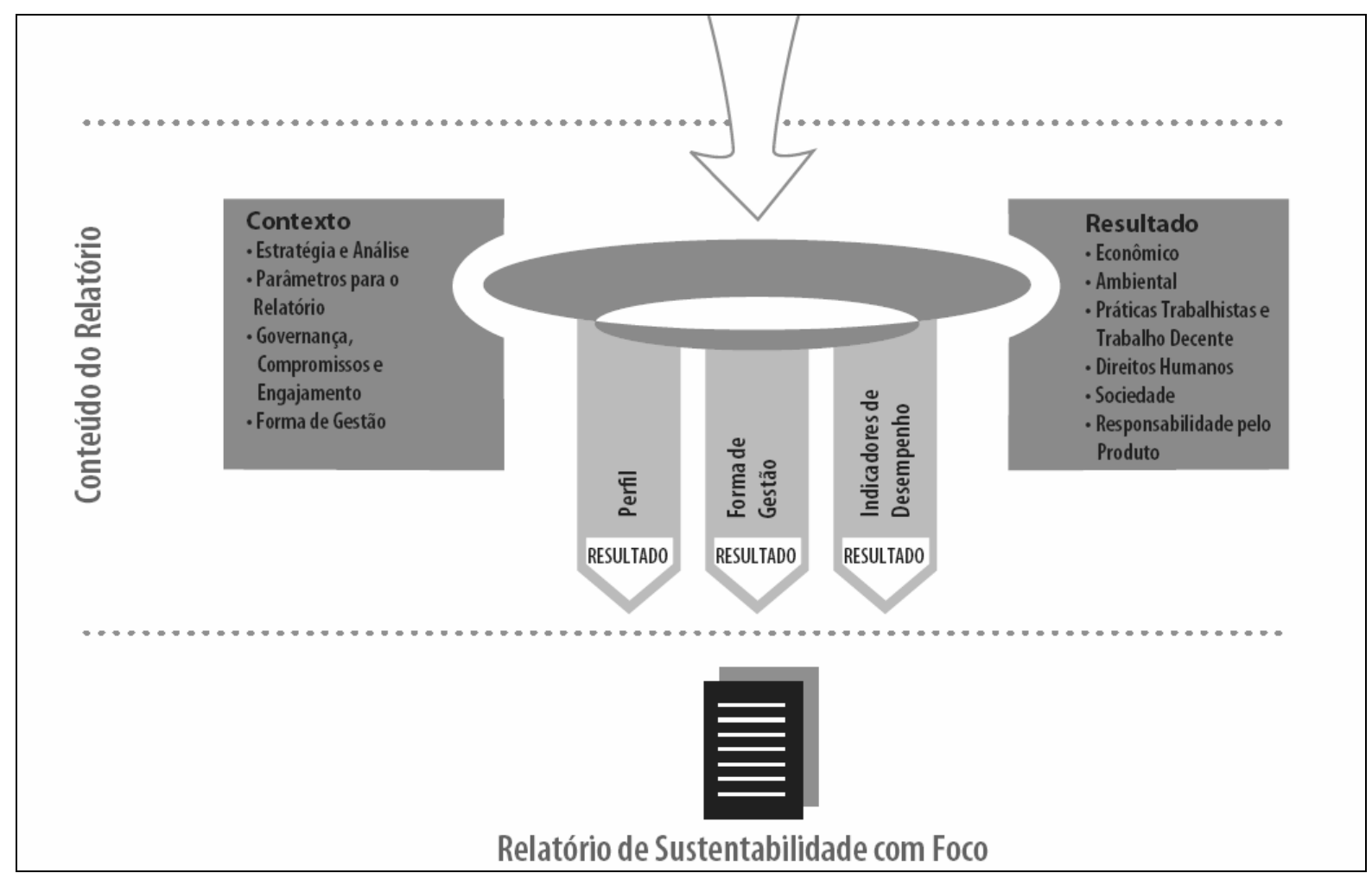

Ilustração 7 - Visão Geral do Conteúdo do Relatório da GRI FONTE: GRI (2006, p. 19)

Apenas duas empresas estruturaram seu relatório usando as quatro vertentes do Balanço Social (FIPECAFI, 2007, p. 10) - Recursos Humanos (RH), Relações com a Comunidade, DVA e Balanço Ambiental. Entretanto, quando observado se as informações das quatro vertentes são evidenciadas, percebe-se que a maioria das empresas analisadas evidencia informações dessas vertentes. As vertentes RH, Comunidade e Meio Ambiente aparecem em $100 \%$ dos relatórios, apesar de muitos não seguirem essa estrutura na organização do 
relatório. A maioria dos relatórios segue a divisão de áreas do modelo GRI (Ilustração 7). O Apêndice 2 traz os sumários de todos os relatórios analisados.

A vertente DVA, ao contrário das outras três, não apareceu em toda a amostra. Em 7 das empresas analisadas, nenhuma informação dessa vertente foi evidenciada e, das 15 restantes, 8 divulgam a informação de valor adicionado, mas não a DVA. Nestas, a informação é divulgada dentro do relatório Ibase (4 empresas), conforme a estrutura GRI (2 empresas), ou ainda divulgam apenas a estrutura de distribuição do valor adicionado ( 2 empresas). Apenas 7 empresas divulgam a DVA com estrutura similar aos modelos vistos no capítulo 3. O Gráfico 4 mostra a distribuição da vertente DVA nos relatórios.

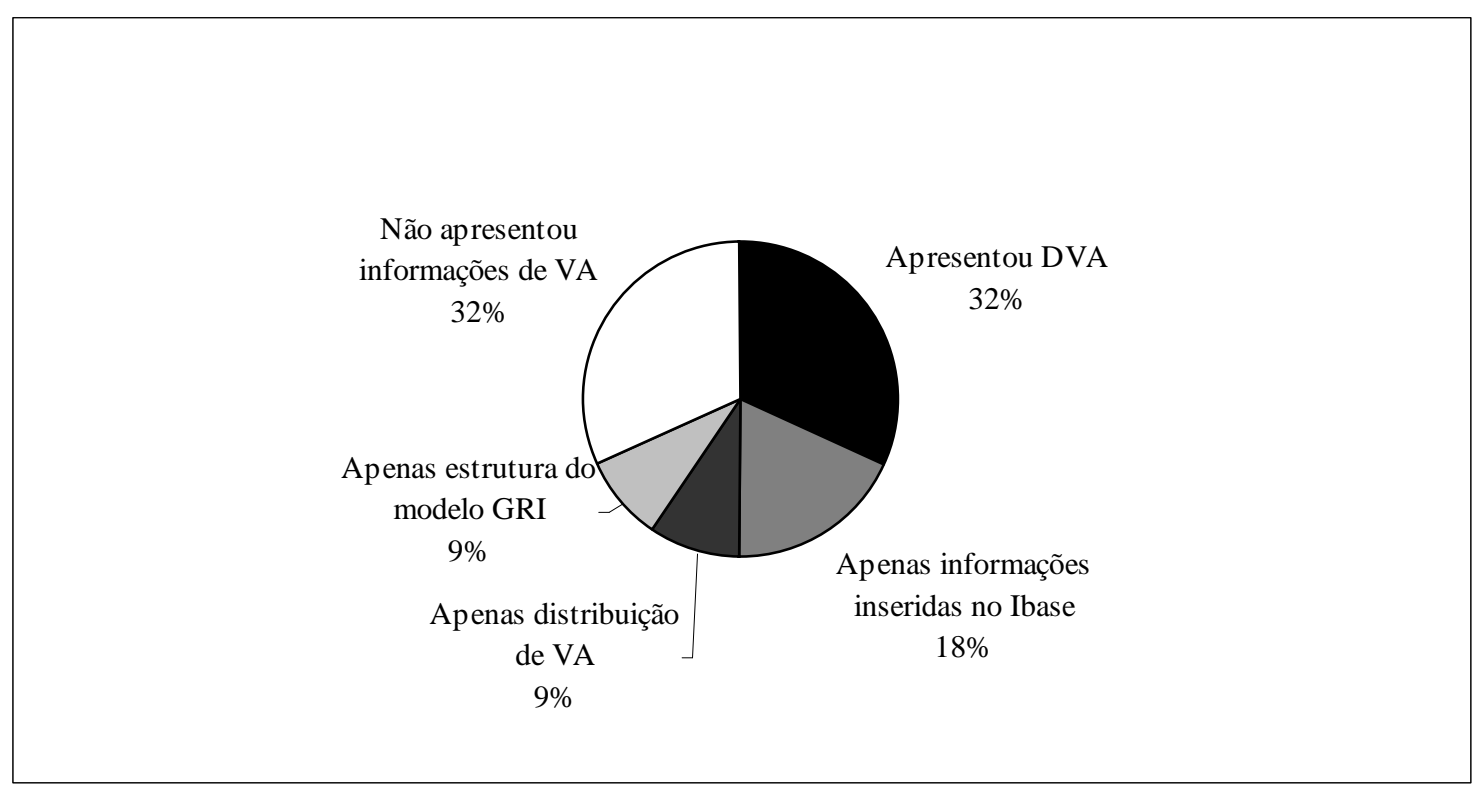

Gráfico 4 - Análise da presença da DVA nos relatórios analisados

O número de páginas dos relatórios não é um dado que retrata o volume de informações dos relatórios analisados. Os relatórios apresentam diversas fotos, muitas vezes de página inteira. O número de parágrafos guarda maior relação com o volume de informações divulgado, mas ainda não pode ser considerado um referencial, pois alguns relatórios mostraram-se bastante repetitivos, trazendo a mesma informação em até três seções diferentes do relatório.

A análise dos resultados, por usar estatística descritiva e trabalhar com o total das observações (são 6.944 parágrafos), pode apresentar distorção devido à variação do número de parágrafos por relatório. Por isso, o Apêndice 3 traz as tabelas com as variáveis distribuídas por empresa. 
Após analisar os dados coletados sobre a empresa e sobre os relatórios, dá-se início à análise das informações divulgadas pelas empresas da amostra. A parte $\mathrm{C}$ do roteiro de avaliação dos relatórios traz as seguintes classificações da informação:

C.1. quanto ao formato: texto, forma gráfica, tabela ou quadro;

C.2. quanto à qualidade da informação: quantitativa monetária, quantitativa não monetária, declarativa ou informação técnica sobre o próprio relatório;

C.3. quanto ao conteúdo da informação: informações históricas da organização, informações sobre atividades referentes ao ano 2007 ou informações do ambiente externo da organização que contextualizam as atividades de 2007;

C.4. quanto à efetividade da atividade informada: valores, práticas ou intenções;

C.5. quanto à etapa de desenvolvimento da atividade: planejamento, execução ou avaliação;

C.6. quanto à categoria da informação (Quadro 9);

C.7. quanto ao relacionamento da atividade com o processo produtivo;

C.8. quanto à "notícia" divulgada pela informação: neutra, boa ou ruim;

C. 9. quanto ao tipo de dispêndio por parte da empresa: monetário, em horas de trabalho dos empregados, em recursos do imobilizado, em estoques ou não envolve nenhum tipo de dispêndio;

C.10. quanto à possibilidade de auditar a informação;

C.11. Quanto ao meio de transferência de recursos da empresa para a atividade declarada.

Conforme descrito no Roteiro de Avaliação dos Relatórios, os quesitos C7 a C11 só foram classificados quando a categoria na questão C6 era Recursos Humanos, Meio Ambiente ou Comunidade.

Apesar de os relatórios apresentarem muitas fotos, os elementos gráficos com informações representam apenas $6 \%$ dos parágrafos analisados, as tabelas e quadros representam $13 \%$, e a maior parte das informações divulgadas pela empresa está disposta na forma de textos, $81 \%$. 
Quadro 9 - Categorias e subcategorias definidas na questão C6 para classificação do investimento social

\begin{tabular}{|c|c|}
\hline \multirow{10}{*}{$\begin{array}{l}\text { 1. Recursos } \\
\text { Humanos }\end{array}$} & a. Dados sobre quantidades de empregados [inclusive por diferentes idades, etnias e gêneros] \\
\hline & b. Avaliação de desempenho e ambiente de trabalho \\
\hline & $\begin{array}{l}\text { c. Prêmios, benefícios, incentivos, planos de carreira e políticas salariais [exceto participação nos } \\
\text { lucros e prêmios em ações] }\end{array}$ \\
\hline & $\begin{array}{l}\text { d. Treinamentos e cursos de capacitação para empregados [exceto em temas relacionados ao meio } \\
\text { ambiente, saúde e segurança no trabalho] }\end{array}$ \\
\hline & e. Previdência dos empregados \\
\hline & f. Emprego de minorias e/ou deficientes \\
\hline & g. Saúde e segurança no trabalho [inclui treinamentos em temas de meio ambiente] \\
\hline & $\begin{array}{l}\text { h. Engajamento dos empregados nas decisões da empresa [ações que incentivem a participação de } \\
\text { empregados nos processo decisórios e/ou informem os empregados sobre as decisões da empresa] }\end{array}$ \\
\hline & i. Participação nos lucros, prêmios em ações ou opções, incentivos para compra de ações \\
\hline & j. Informações de conjuntura com seus impactos nos empregados da empresa. \\
\hline \multirow{7}{*}{$\begin{array}{l}\text { 2. Meio } \\
\text { Ambiente }\end{array}$} & a. Realização de projetos ambientais em parceria com outras instituições, públicas ou privadas \\
\hline & $\begin{array}{l}\text { b. Políticas Ambientais da empresa [inclui informações de conjuntura com seus impactos nas } \\
\text { decisões tomadas pela empresa] }\end{array}$ \\
\hline & $\begin{array}{l}\text { c. Sistemas de Gerenciamento Ambiental [procedimentos incluídos no processo operacional da } \\
\text { empresa com o objetivo de melhorar sua relação com o meio ambiente] }\end{array}$ \\
\hline & d. Impactos dos Produtos e Processos [inclusive uso da água e energia e passivos ambientais] \\
\hline & $\begin{array}{l}\text { e. Investimentos em ativos ambientais [considerar ativo ambiental os bens e direitos que tenham } \\
\text { capacidade de geração de benefício econômico em períodos futuros e que visem à preservação, } \\
\text { proteção e recuperação ambiental (RIBEIRO, 2006, p. 61)] }\end{array}$ \\
\hline & f. Educação, Pesquisa e Treinamento [exceto para empregados da empresa] \\
\hline & g. Mercado de Créditos de Carbono \\
\hline \multirow{8}{*}{$\begin{array}{l}\text { 3. Comuni- } \\
\text { dade }\end{array}$} & a. Realização de projetos sociais na comunidade \\
\hline & b. Doações em espécie para projetos sociais da comunidade \\
\hline & c. Doações de bens e mercadorias (ou serviços) para a comunidade \\
\hline & d. Voluntariado empresarial quando o apoio da empresa for evidente \\
\hline & e. Patrocínios a escolas, artes e esportes \\
\hline & f. Parcerias público-privadas quando o beneficiário for a comunidade \\
\hline & g. Doações para o governo \\
\hline & h. Doações para campanhas políticas \\
\hline 4. DVA & [mesmo que as informações da DVA estejam desmembradas no Relatório] \\
\hline \multirow{4}{*}{$\begin{array}{l}\text { 5. Consumi- } \\
\text { dores }\end{array}$} & a. Segurança do produto e para o consumidor \\
\hline & b. Serviços de atendimento ao consumidor \\
\hline & c. Atendimento especial para consumidores deficientes e idosos \\
\hline & d. Atendimento especial para consumidores "afastados" \\
\hline \multirow{6}{*}{ 6. Empresa } & a. Desempenho Financeiro \\
\hline & $\begin{array}{l}\text { b. Desempenho Mercadológico [informações sobre crescimento da empresa, participação de } \\
\text { mercado, campanhas publicitárias etc.] }\end{array}$ \\
\hline & $\begin{array}{l}\text { c. Processo operacional [quando a informação refere-se ao processo de produção da empresa em } \\
\text { sua operação principal] }\end{array}$ \\
\hline & $\begin{array}{l}\text { d. Desempenho Socioambiental [apenas quando a empresa declara prêmios recebidos pela atuação } \\
\text { socioambiental da empresa como um todo] }\end{array}$ \\
\hline & $\begin{array}{l}\text { e. Políticas e valores da empresa [quando relacionada apenas à operação da empresa e seu contexto } \\
\text { - não envolvem políticas e valores com empregados, meio ambiente ou ações com a comunidade] }\end{array}$ \\
\hline & f. Desenvolvimento ou venda de produtos com forte apelo socioambiental \\
\hline $\begin{array}{l}\text { 7. Objetivos } \\
\text { globais }\end{array}$ & $\begin{array}{l}\text { Adoção de objetivos globais de sustentabilidade [classificar aqui as declarações de anuência a } \\
\text { políticas nacionais ou globais - não desenvolvidas pela empresa - como: Objetivos do Milênio, } \\
\text { Princípios do Equador, Pacto Global etc.] }\end{array}$ \\
\hline 8. Outros & [sempre que houver classificação nesse grupo, registrar o evento no bloco de anotações] \\
\hline
\end{tabular}


Um quesito importante dos investimentos sociais para a pesquisa em contabilidade é o valor do investimento. $\mathrm{O}$ quesito $\mathrm{C} 2$ da análise das informações buscava identificar informações financeiras, por isso classificava a informação em quantitativa ou não. A Tabela 9 mostra que a maioria dos parágrafos traz apenas informações declarativas, 59\%, e apenas $11 \%$ dos parágrafos trazem alguma informação financeira. Isso corrobora a percepção do processo de coleta de dados, pois era frequente a descrição de projetos nos quais a empresa se dizia envolvida, mas não declarava exatamente como se dava a relação com o projeto nem qual o valor investido.

Tabela 9 - Classificação das informações divulgadas nos relatórios quanto à qualidade da informação

\begin{tabular}{|c|c|}
\hline \multicolumn{2}{|l|}{ Quanto à qualidade da informação } \\
\hline quantitativa monetária & $8 \%$ \\
\hline quantitativa não monetária & $28 \%$ \\
\hline quantitativa monetária e não monetária & $3 \%$ \\
\hline declarativa & $59 \%$ \\
\hline informação técnica sobre o relatório & $2 \%$ \\
\hline Totc & $100 \%$ \\
\hline
\end{tabular}

A título de exemplo, o relatório da Braskem, na descrição das ações junto à comunidade externa, declara ter participado do Instituto Trata Brasil. Mais à frente, na descrição das ações que tiveram continuidade em 2007, fala do projeto Vila Pinto. Entretanto, questiona-se: houve investimento da companhia nos projetos em 2007? Quanto? Houve dispêndio monetário ou entrega de outros ativos? A empresa se beneficia do projeto? Como (dando destino aos seus resíduos, por exemplo)? São apenas dois exemplos dos muitos casos encontrados nesse e em outros relatórios. Para analisar se há distribuição de renda da empresa para esses projetos é fundamental que essas perguntas sejam respondidas.

A Braskem participou em 2007 da criação do Instituto Trata Brasil, organização com sede em São Paulo que tem como finalidade promover, apoiar e desenvolver ações de conscientização e mobilização visando à universalização do saneamento básico. A iniciativa responde ao estímulo dado pela Companhia aos empresários parceiros para que invistam em causas de interesse público com a mesma responsabilidade e critérios com que cuidam dos negócios, de maneira que os efeitos dos investimentos sociais componham os resultados não-econômicos de cada Unidade de Negócios. (BRASKEM, 2007, p. 16).

Centro de Educação Ambiental Vila Pinto, voltado para a geração de renda de famílias dessa comunidade da periferia da região metropolitana de Porto Alegre. A Braskem iniciou sua participação em 1999, com a doação de equipamentos para separação de resíduos sólidos, e em 2007 manteve parceria com o Centro Federal de Educação Tecnológica - Cefet para aprimorar a gestão do Centro. Em suas instalações são recicladas aproximadamente 60 toneladas de material por mês, nas quais $80 \%$ são plásticos, matéria-prima que sustenta a atividade da comunidade. $\mathrm{O}$ 
espaço possui, ainda, sala de informática, biblioteca e sala de cinema. Mais de 2 mil pessoas foram atendidas por mês em suas oficinas de costura, informática, dança e teatro. (Ibid., p. 21).

O quesito C3 foi criado após o teste do roteiro de avaliação. Percebeu-se a existência de muitas informações que não diziam respeito ao período relatado (2007) ou não diziam respeito à empresa (4\% e 9\% dos parágrafos, respectivamente), portanto, não havia sentido em classificar a informação. Assim, esse quesito era um filtro, e só as informações referentes a atividades de 2007 ( $87 \%$ dos parágrafos) continuavam a ser classificadas conforme o roteiro de avaliação.

As empresas não declaram apenas as atividades realizadas. Elas também informam suas intenções e seus valores. O quesito C4 avaliava a efetividade da atividade informada. Quando a empresa declara ser contra qualquer tipo de preconceito, está informando um valor da companhia e não uma prática. Quando a empresa declara uma meta para o ano seguinte, está informando uma intenção e não uma prática. Esse quesito é relevante porque só as práticas podem ser consideradas investimentos sociais. As intenções foram encontradas em $7 \%$ dos parágrafos analisados, os valores em $9 \%$ e as práticas em $84 \%$.

Por fim, antes da categorização principal do estudo empírico, a informação foi classificada quanto à etapa de desenvolvimento da atividade. Mostraram-se em fase de planejamento, $8 \%$ das informações declaradas pelas empresas, em fase de execução, $68 \%$, e $24 \%$ das informações diziam respeito à avaliação de programas executados pela empresa.

A classificação das informações entre as categorias do quesito C6 - Recursos Humanos, Meio Ambiente, Comunidade, DVA, Consumidores, Empresa, Adoção de Objetivos Globais e Outros - dará subsídio para a definição de uma estrutura capaz de abranger os diferentes tipos de investimentos sociais. Por isso, ao analisar os resultados de cada categoria e suas subcategorias, haverá um exame da adequação da estrutura utilizada à prática observada e serão realizadas alterações em tal estrutura, quando necessárias.

O Gráfico 5 mostra a distribuição dos parágrafos entre as grandes categorias definidas. Fica evidente que mais da metade das informações divulgadas dizem respeito à própria empresa, isto é, dizem respeito ao desempenho da empresa, sua relação com fornecedores, características do seu processo produtivo etc. Os volumes de informações sobre RH, Ambiente e Comunidade apresentam certo equilíbrio, mas prevalecem as informações sobre 
RH. A categoria DVA, como esperado, tem participação inexpressiva, porque, na maior parte dos casos, a demonstração é exposta sem discuti-la ou analisar seus valores. Portanto, na análise de conteúdo dos relatórios, a DVA toda foi considerada um único parágrafo (uma tabela). O mesmo acontece com a declaração de adoção dos objetivos globais, pois um único parágrafo é suficiente para declarar a anuência com tais programas.

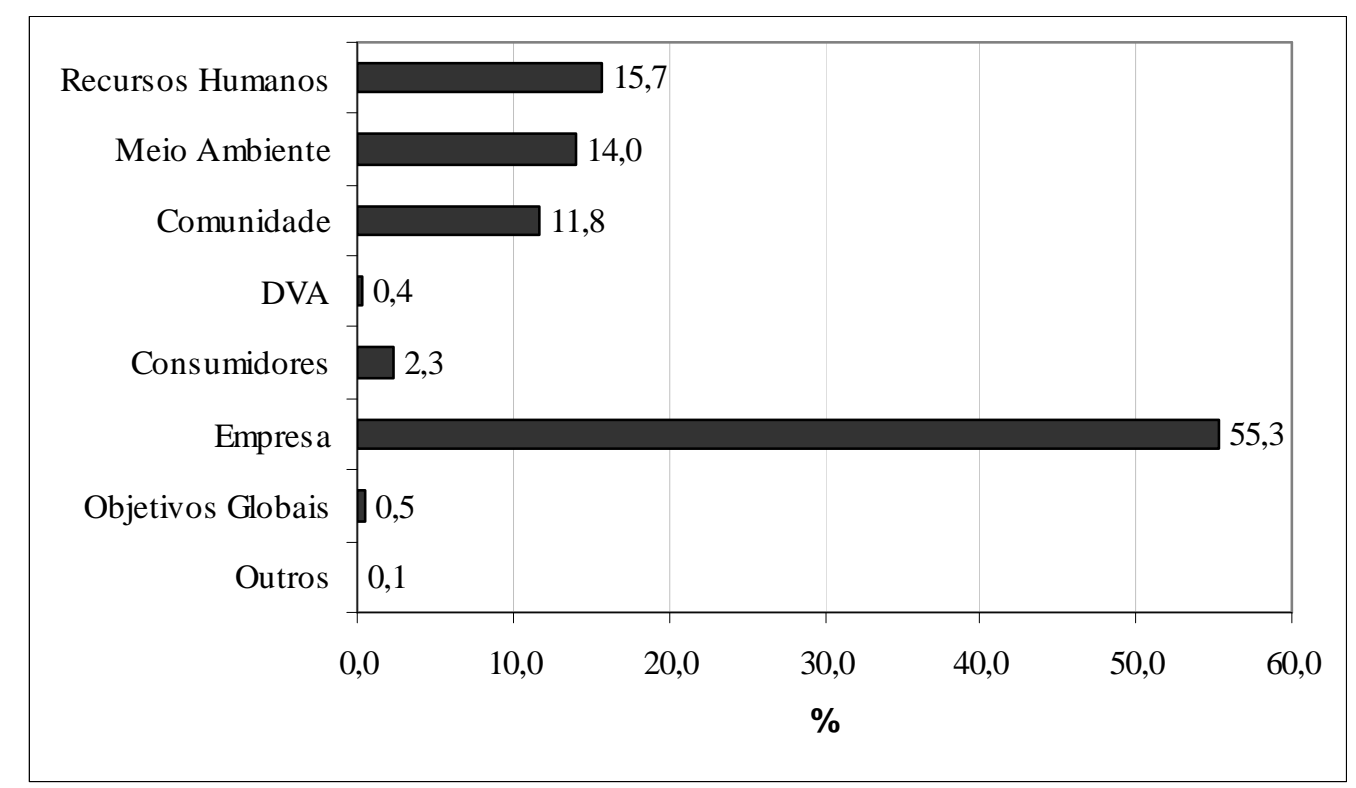

Gráfico 5 - Distribuição das informações divulgadas entre as categorias de sustentabilidade

Como a definição de categorias ocorreu em conformidade com trabalhos acadêmicos que também classificaram informações socioambientais, esperavam-se poucas ocorrências na categoria outros, ou seja, as categorias definidas seriam suficientes para classificar todas as informações declaradas na amostra estudada. De fato, apenas cinco parágrafos foram classificados na categoria outros. Dois parágrafos, de empresas diferentes (Sabesp e Bradesco), falavam sobre relação com investidores, um falava sobre a criação de uma área de Responsabilidade Social na estrutura organizacional (Bradesco) e dois falavam sobre direitos indígenas (Vale). Para resolver os dois primeiros casos, foi criada uma subcategoria do grupo empresas: estrutura de governança e relação com acionistas. Quanto ao caso dos direitos indígenas, foi criada subcategoria do grupo Comunidade: conflitos entre a empresa e a comunidade. Com isso, foi necessária a criação de novas categorias, por outro lado algumas subcategorias não foram usadas. Por isso, serão analisadas todas as subcategorias do quesito C6. 
O Gráfico 6 mostra como as informações de Recursos Humanos foram classificadas em suas subcategorias. Percebe-se maior volume de informações sobre saúde e segurança no trabalho. Talvez o objetivo seja minimizar o risco financeiro inerente aos processos operacionais, pois tanto acidentes de trabalho, quanto problemas de saúde dos funcionários geram despesas para a companhia, portanto diminuem sua rentabilidade. Ao mostrar programas que minimizam esses riscos, a empresa pode aumentar a projeção dos investidores sobre seus fluxos de caixa futuros.

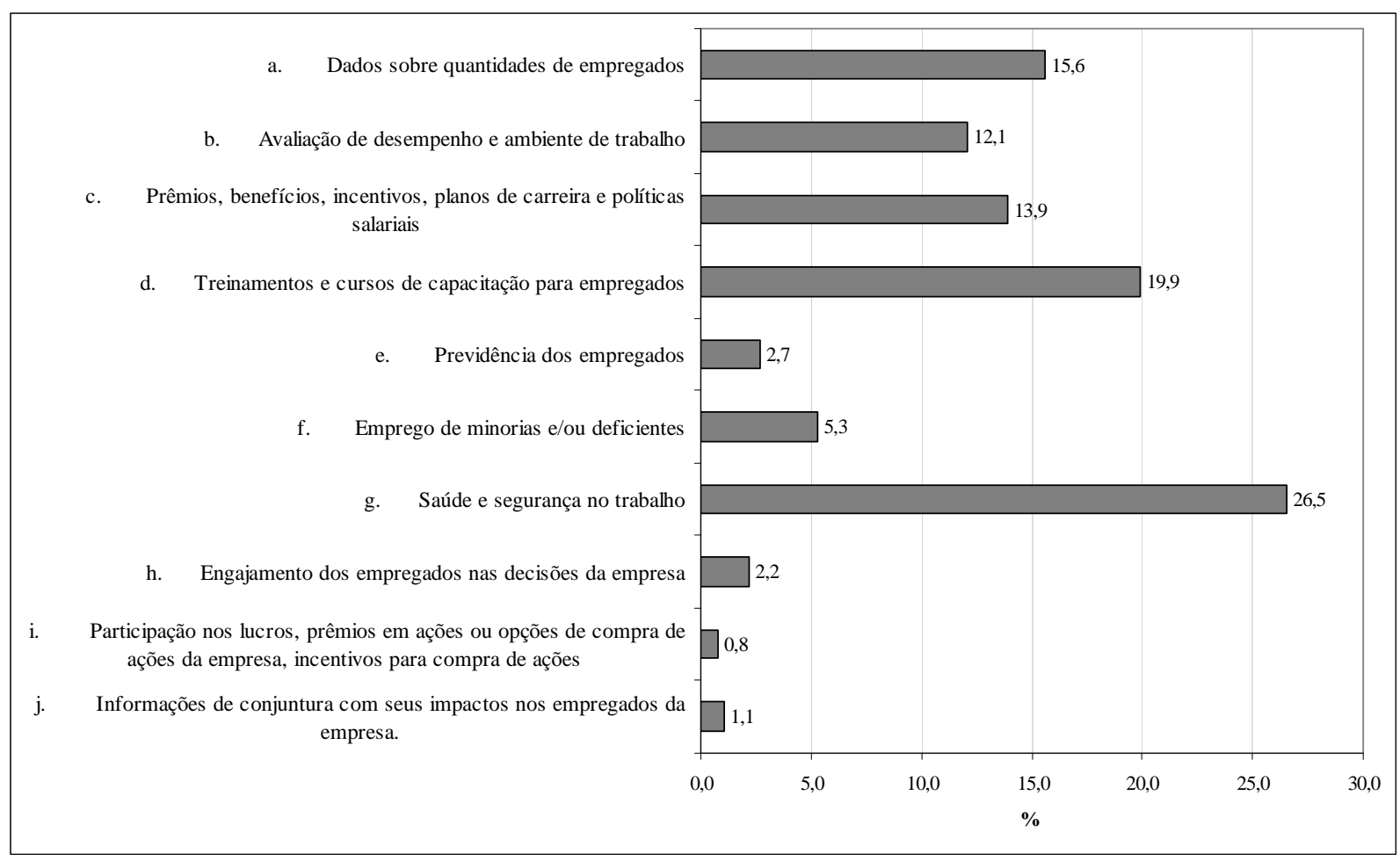

Gráfico 6 - Distribuição das informações de Recursos Humanos entre suas subcategorias

Nessa categoria, todas as subcategorias foram utilizadas e mostraram-se eficientes para classificar as informações fornecidas nos relatórios. O menor volume de informações classificadas em determinada subcategoria, não significa sua irrelevância, significa que poucos parágrafos podem definir a atuação da empresa no quesito em questão ou que a empresa não tem interesse em aprofundar tal informação.

O uso das subcategorias de Meio Ambiente estão expostas no Gráfico 7. Apesar de todas as categorias terem sido utilizadas, as informações sobre Meio Ambiente geraram dúvidas frequentes entre classificar determinados parágrafos em processo operacional na categoria empresa (6c) ou sistema de gerenciamento ambiental na categoria meio ambiente (2c). Por 
isso, a categoria 6c teve sua definição alterada de "Sistemas de Gerenciamento Ambiental [procedimentos incluídos no processo operacional da empresa com o objetivo de melhorar sua relação com o meio ambiente]" para "Sistemas de Gerenciamento Ambiental [procedimentos incluídos no processo operacional da empresa com o objetivo de minimizar o impacto dos resíduos gerados pela empresa ao meio ambiente]”.

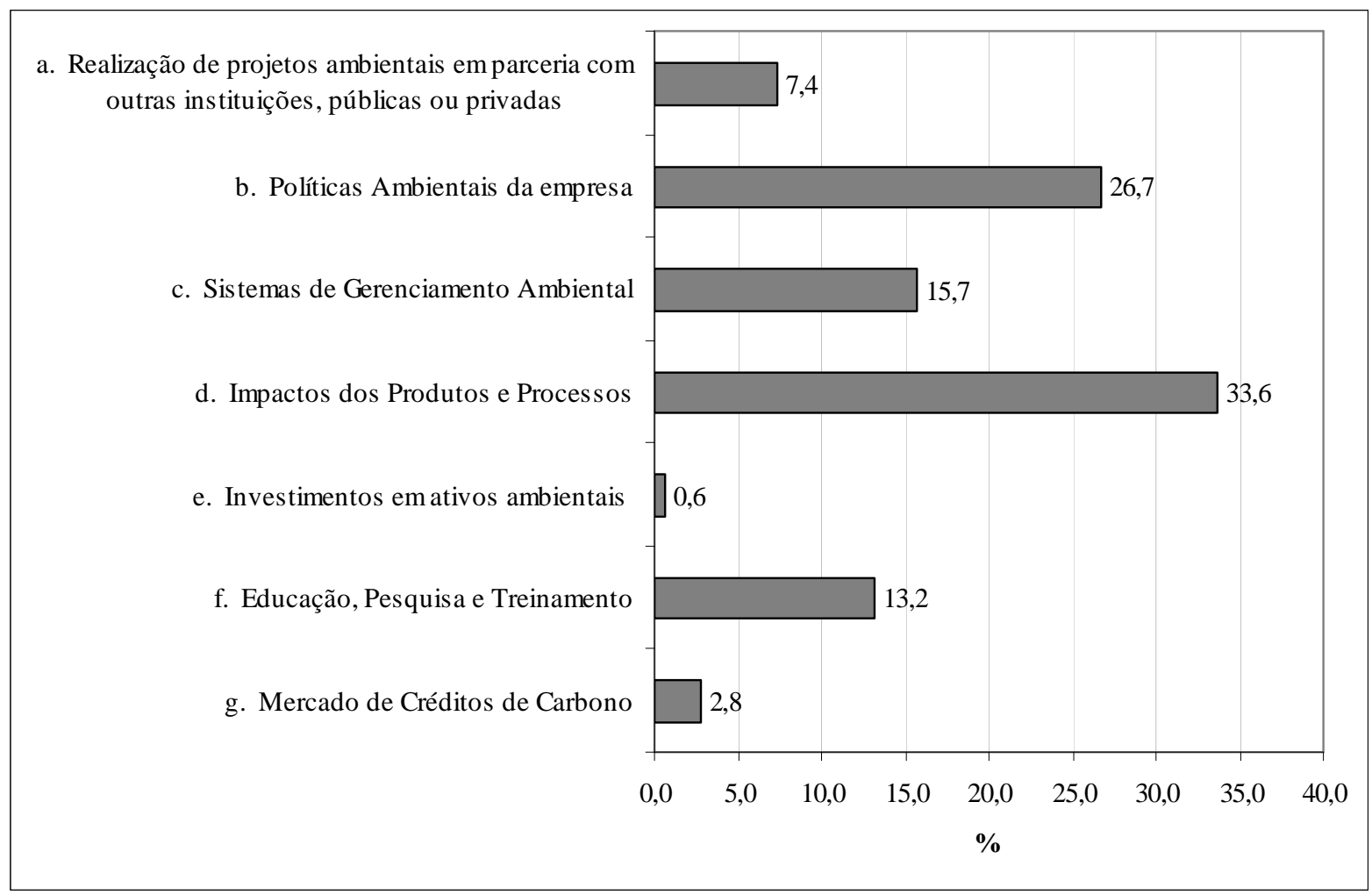

Gráfico 7 - Distribuição das informações de Meio Ambiente entre suas subcategorias

As maiores dificuldades de classificação ocorreram na categoria Comunidade. Em parte, isso ocorreu devido às informações confusas divulgadas pelas empresas, pois há muita "apropriação" dos serviços sociais de entidades sem fins lucrativos beneficiadas pela organização em algum momento. Ou seja, as entidades descrevem ações das entidades beneficiadas como se todas fossem fruto de seu investimento, mas não diz o valor do investimento ou qual sua contribuição. Já foi citado como exemplo o caso da Braskem. Entretanto, parte da dificuldade de classificação deve-se à falta de especificação das subcategorias. O Gráfico 8 mostra o grande volume de informações classificadas na categoria 3a $(52 \%)$. No processo de coleta de dados, foi possível perceber que a classificação em 3a ocorria por falta de evidências da doação realizada, nem sempre porque a empresa participou de todo o projeto social (como era a intenção inicial no desenvolvimento do roteiro). 


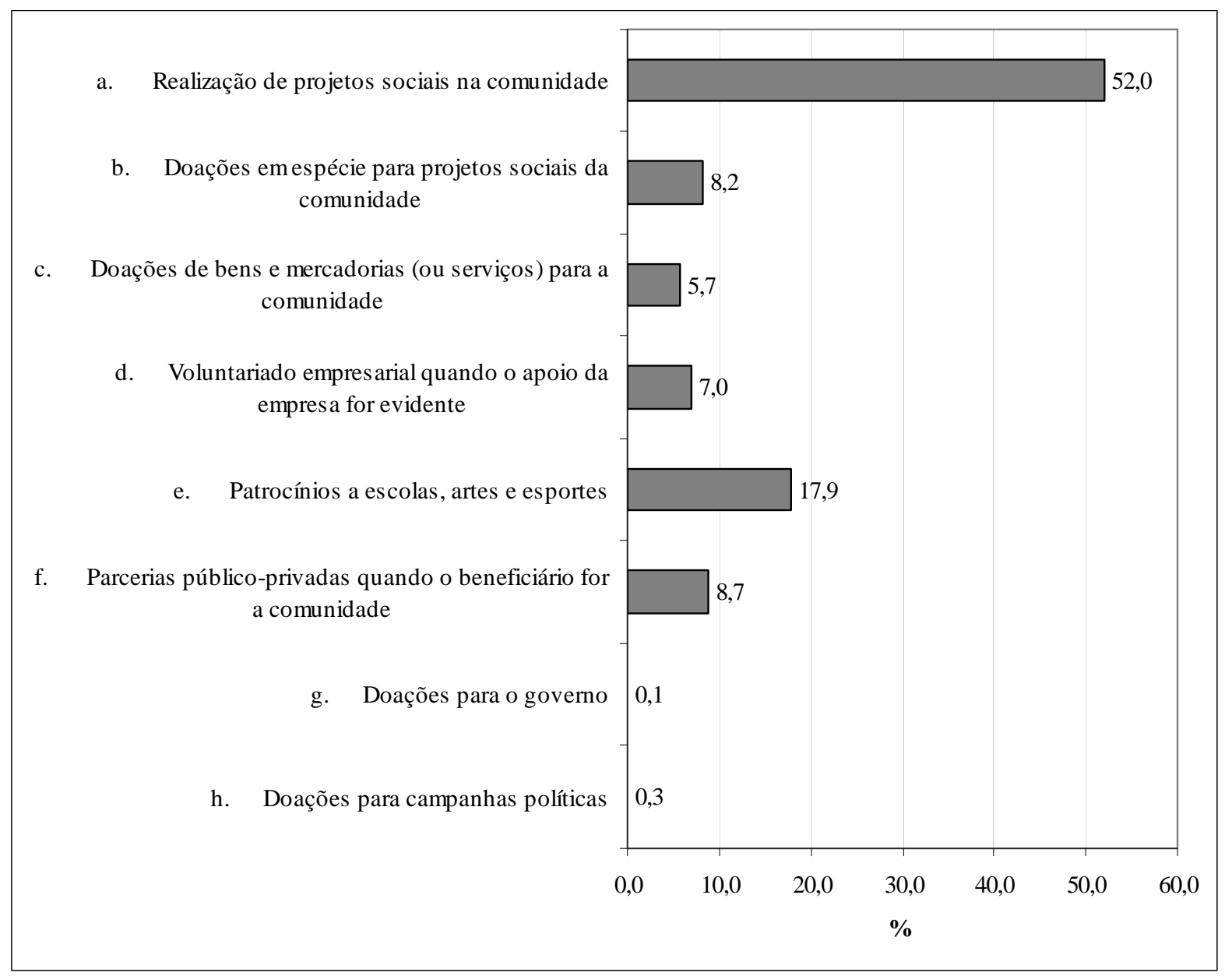

Gráfico 8 - Distribuição das informações de Relações com a Comunidade entre suas subcategorias

Como a categoria comunidade está entre aquelas com menor volume de informações (Gráfico 5), não foi possível identificar esse problema nos testes do instrumento de coleta de dados. Com isso, houve uma reestruturação da categoria Comunidade:

a. realização de projetos sociais na comunidade [quando a participação efetiva da empresa for evidente];

b. doações para projetos sociais da comunidade;

c. doações para programas sociais do governo;

d. voluntariado empresarial quando o apoio da empresa envolver algum tipo de investimento [por exemplo, em horas de trabalho];

e. patrocínios à educação, artes e aos esportes [quando há o custeio da atividade com a divulgação explícita da marca da empresa no projeto];

f. conflitos entre a comunidade externa e a empresa ou seu processo operacional;

g. doações para campanhas políticas. 
A categoria Consumidor não é expressiva na amostra analisada. Além de representar apenas 2,3\% dos parágrafos analisados, 10 das 22 empresas analisadas não apresentaram nenhum parágrafo classificado nessa categoria. O Gráfico 9 mostra alta concentração das informações em atendimento ao consumidor e em características de segurança do produto ou serviço oferecido. $\mathrm{O}$ item de atendimento especial para consumidores afastados (distante dos centros comerciais) mostrou-se desnecessário, pois as informações poderiam ser classificadas como serviços de atendimento ao consumidor. Com essa análise, optou-se por transformar a categoria Consumidor em uma subcategoria da categoria Empresa.

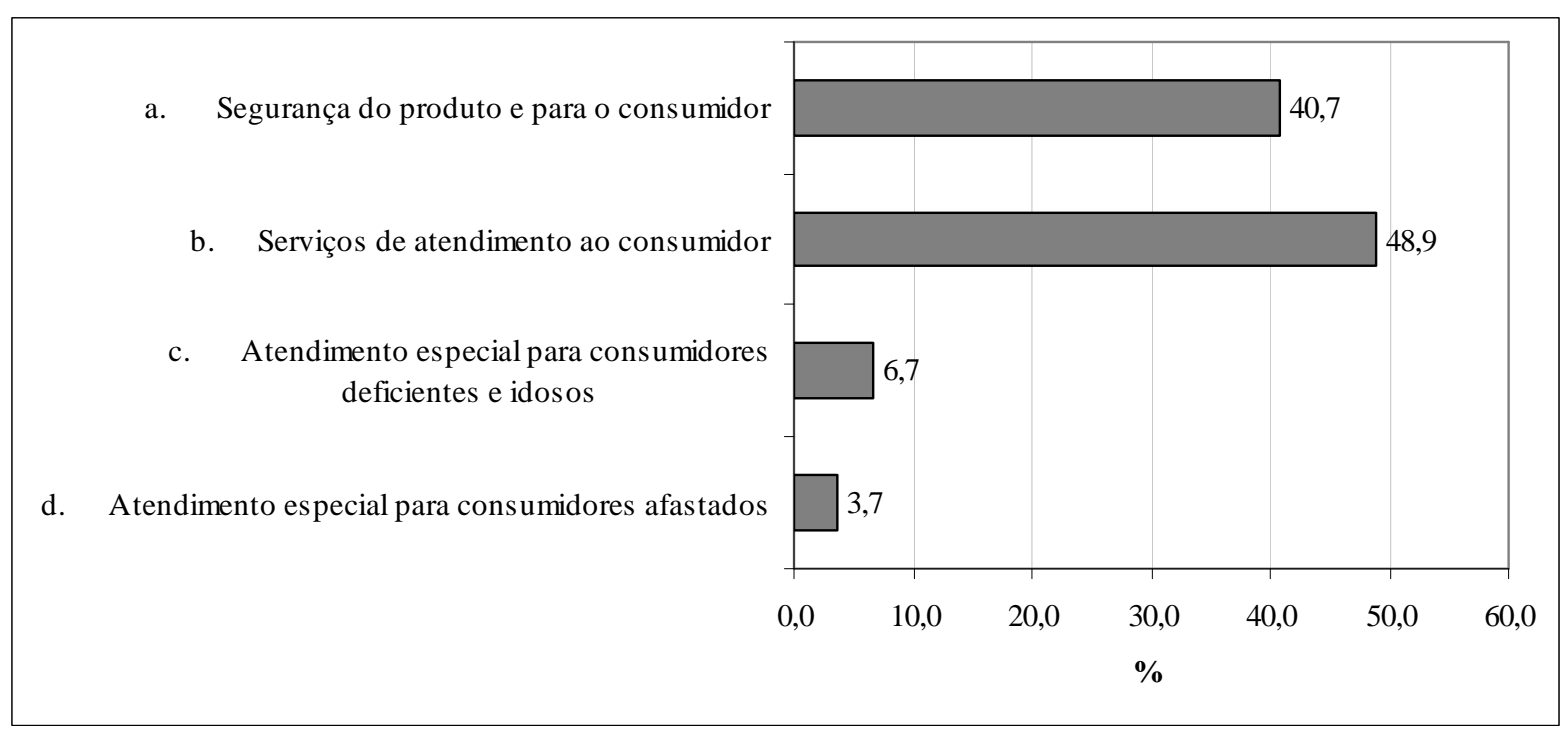

Gráfico 9 - Distribuição das informações de Consumidores entre suas subcategorias

A categoria empresa concentrou 55,3\% do total de parágrafos analisados. Destes, quase $50 \%$ traziam informações sobre políticas, estratégias e valores da empresa (Gráfico 10). As subcategorias definidas foram capazes de classificar as informações divulgadas, com exceção das informações sobre relacionamento com acionistas, conforme já mencionado, e das informações sobre relacionamento com fornecedores. Estas últimas foram classificadas como parte do processo operacional por se tratar das matérias-primas da produção, mas seria mais adequado incluir uma subcategoria para os fornecedores. Por isso, foi criada a subcategoria relação com fornecedores dentro da categoria Empresa.

Estratégias, políticas e valores não mudam com frequência, logo cerca de $28 \%$ das informações divulgadas nos relatórios devem vir se repetindo nos últimos anos. Assim, seria interessante que os relatórios tivessem uma seção separada para as políticas e valores da 
organização. As informações dessa qualidade, em sua maioria, não são verificáveis, não envolvem investimento socioambiental direto (política não implica, necessariamente, em investimento) e, portanto, configuram-se apenas em formação de imagem da companhia.

As informações dessa categoria, quando se configurarem investimentos, sempre serão gastos da empresa inerentes ao seu processo produtivo e a sua política de gestão. Então, não podem ser considerados investimentos sociais nem ambientais, são investimentos na melhoria da imagem da empresa, sua produtividade ou lucratividade.

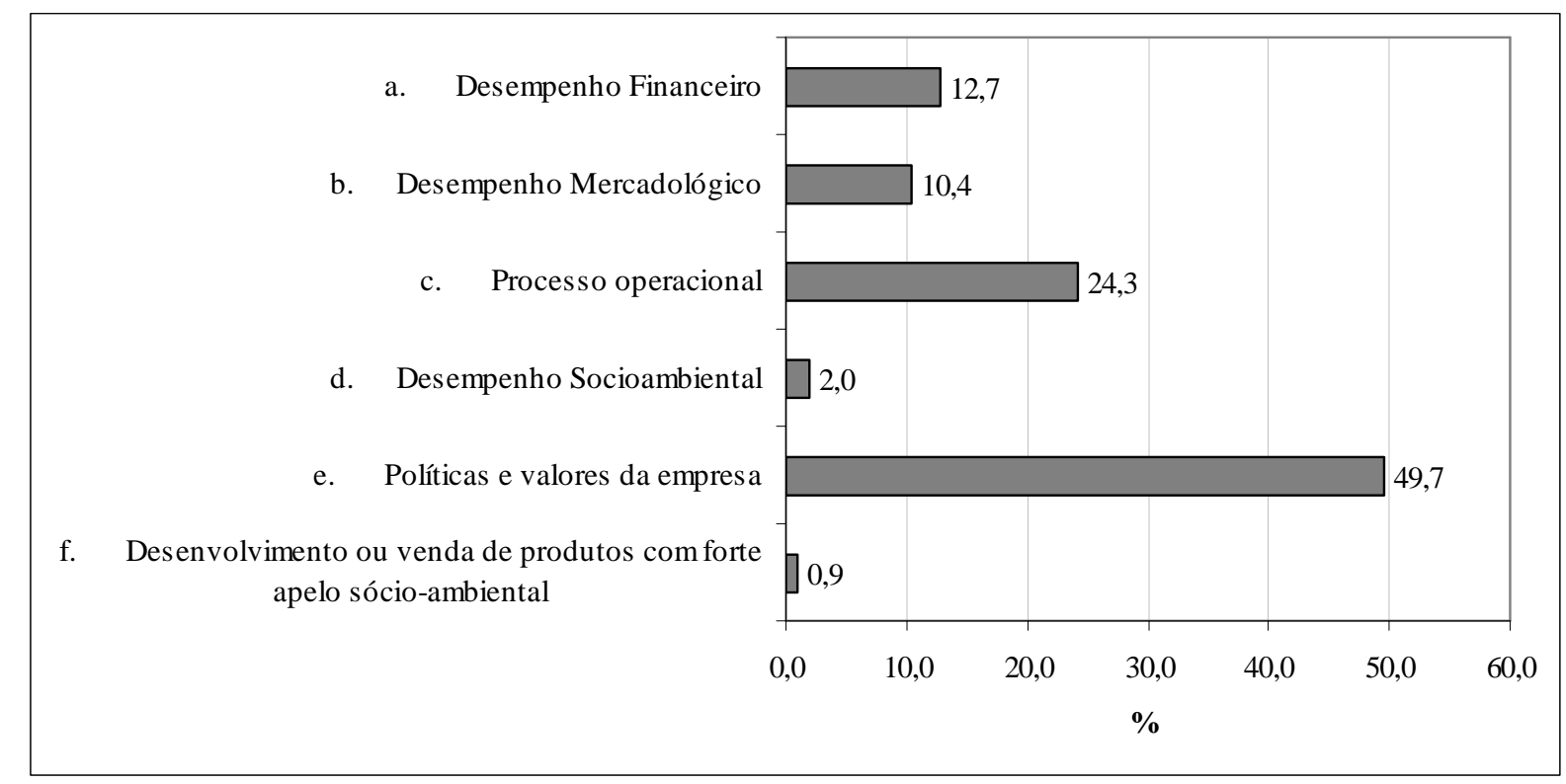

Gráfico 10 - Distribuição das informações sobre a Empresa entre suas subcategorias

Além de investigar qual a natureza do investimento socioambiental, para análise do problema de pesquisa desta tese, é necessário investigar a relação da informação com o processo produtivo e, principalmente, se há dispêndio por parte da companhia e como ele é realizado. Essas questões foram colocadas nos quesitos C7 a C11 do roteiro de avaliação dos relatórios. Entretanto, como essas informações nem sempre são explícitas, a coleta de dados, nesses quesitos, foi permeada de julgamento do pesquisador. Sem dúvida, essa é uma limitação do trabalho, mas era importante tentar investigar essas questões.

Apenas as informações categorizadas nos itens Recursos Humanos, Meio Ambiente e Comunidade e ainda reconhecidas como práticas (não valor, nem intenções - quesito C4) foram classificadas para esses quesitos. 
O quesito C8 buscava identificar se foram divulgadas voluntariamente apenas "boas notícias", aquelas com impacto positivo na avaliação da empresa, conforme teoria da divulgação voluntária de Verrecchia (2001). De fato, a presença de informações boas e neutras (72\% e $23 \%$, respectivamente) é muito superior aos $5 \%$ das informações caracterizadas como ruins.

Apesar de dar grande ênfase às boas notícias, as empresas divulgaram mais informações auditáveis (94\%) que não auditáveis. Este trabalho classificou como informação auditável aquela para a qual é possível definir uma metodologia de verificação da informação. Ou seja, existe a possibilidade de auditar a informação, mas não significa que já houve tal verificação.

De acordo com as teorias instrumentais abordadas no Capítulo 2, os investimentos socioambientais são instrumentos para maximizar o retorno da empresa. Por esse raciocínio, os investimentos identificados na pesquisa empírica deveriam, de alguma forma, estar sempre relacionados com o processo produtivo da empresa. Assim, o quesito C7 avaliou em que as práticas das empresas estavam relacionadas com seus processos produtivos, conforme a seguinte classificação:

- práticas relacionadas a pessoas que trabalham direta ou indiretamente no processo produtivo da empresa;

- práticas relacionadas aos produtos e serviços produzidos pela empresa em qualquer etapa de seu ciclo de vida;

- práticas relacionadas ao consumo de recursos naturais ou emissão de resíduos durante o processo produtivo da empresa;

- ações, na comunidade ou com seu público interno, relacionadas com impactos (passados, presentes ou futuros) gerados pela própria empresa e/ou seu processo produtivo na sociedade;

- atividade não está relacionada, em nenhuma vertente, ao processo produtivo da empresa.

As alternativas de respostas para esse quesito apresentam três relações diretas com o processo produtivo (pessoas, produtos, consumo de recursos naturais), mas também uma relação indireta. Esta última inclui as práticas que buscam compensar prejuízos causados por seus produtos ou por seu processo produtivo. Ou seja, são ações relacionadas às externalidades negativas geradas pela companhia. 
Sempre que um indivíduo ou firma empreende uma ação que tem um efeito em outro indivíduo ou firma, pelo qual este último não paga ou não é pago, há uma externalidade. A externalidade pode ser positiva, quando o efeito causado é benéfico, ou negativa, quando, ao contrário, o efeito causado é prejudicial (STIGLITZ, 2002, p. 215). Um exemplo de ação social que busca compensar externalidade negativa vem da Companhia de Bebidas Ipiranga, fábrica da Coca-Cola situada em Ribeirão Preto. A empresa apresenta em seu Balanço Social um projeto de reciclagem que inclui palestras educativas para crianças de escolas públicas do município de Ribeirão Preto e troca de material reciclável (inclusive latas de alumínio e garrafas PET) por prêmios para as mesmas escolas (computadores, bicicletas, livros etc.). A empresa inclusive coloca nas escolas tambores para coleta de lixo reciclável. O lixo reciclável é vendido pela companhia ou trocado por matéria-prima. Fica evidente que a empresa está declarando um projeto de educação ambiental na comunidade, mas, na verdade, está recolhendo resíduos gerados pela própria atividade. Isso não tira o mérito do projeto como ação social, mas o descaracteriza como altruísmo da empresa.

O Gráfico 11 mostra a distribuição das respostas. A alta concentração de informações sobre práticas relacionadas a pessoas acontece porque $100 \%$ das práticas de Recursos Humanos foram classificadas, obviamente, como práticas relacionadas a pessoas envolvidas no processo produtivo da empresa. Por isso, o Gráfico 12 traz a distribuição das respostas conforme as categorias Comunidade e Meio Ambiente.

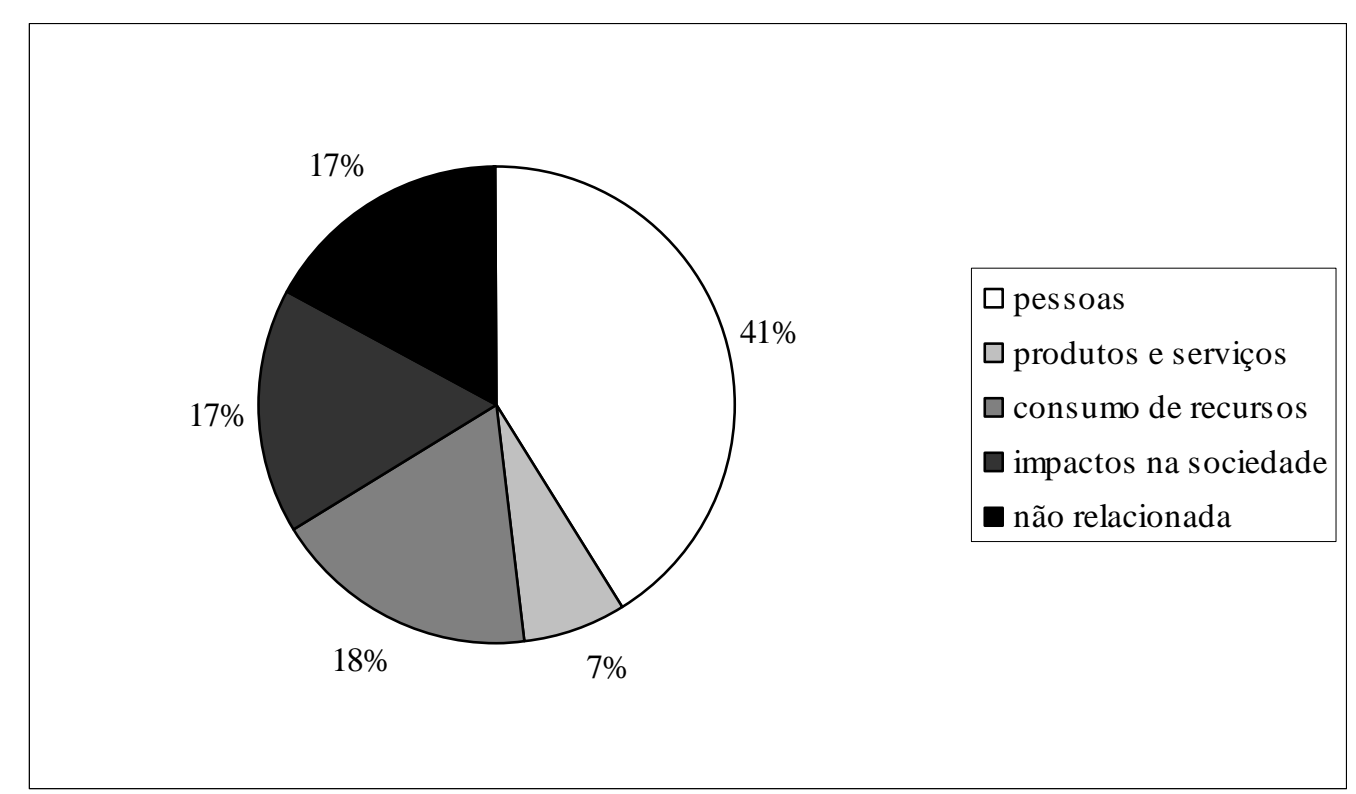

Gráfico 11 - Classificação das informações conforme o relacionamento da prática social com o processo produtivo da companhia 
A categoria Meio Ambiente apresenta mais da metade de suas práticas relacionadas ao consumo de recursos naturais, enquanto na categoria Comunidade mais da metade das práticas não apresenta relação evidente com o processo produtivo. As práticas relacionadas com as externalidades das empresas representam 22\% das ações de Meio Ambiente e 30\% das ações com a Comunidade. É uma participação significativa, reforçando a necessidade de incluir a questão das externalidades nas análises do problema de pesquisa desta tese.

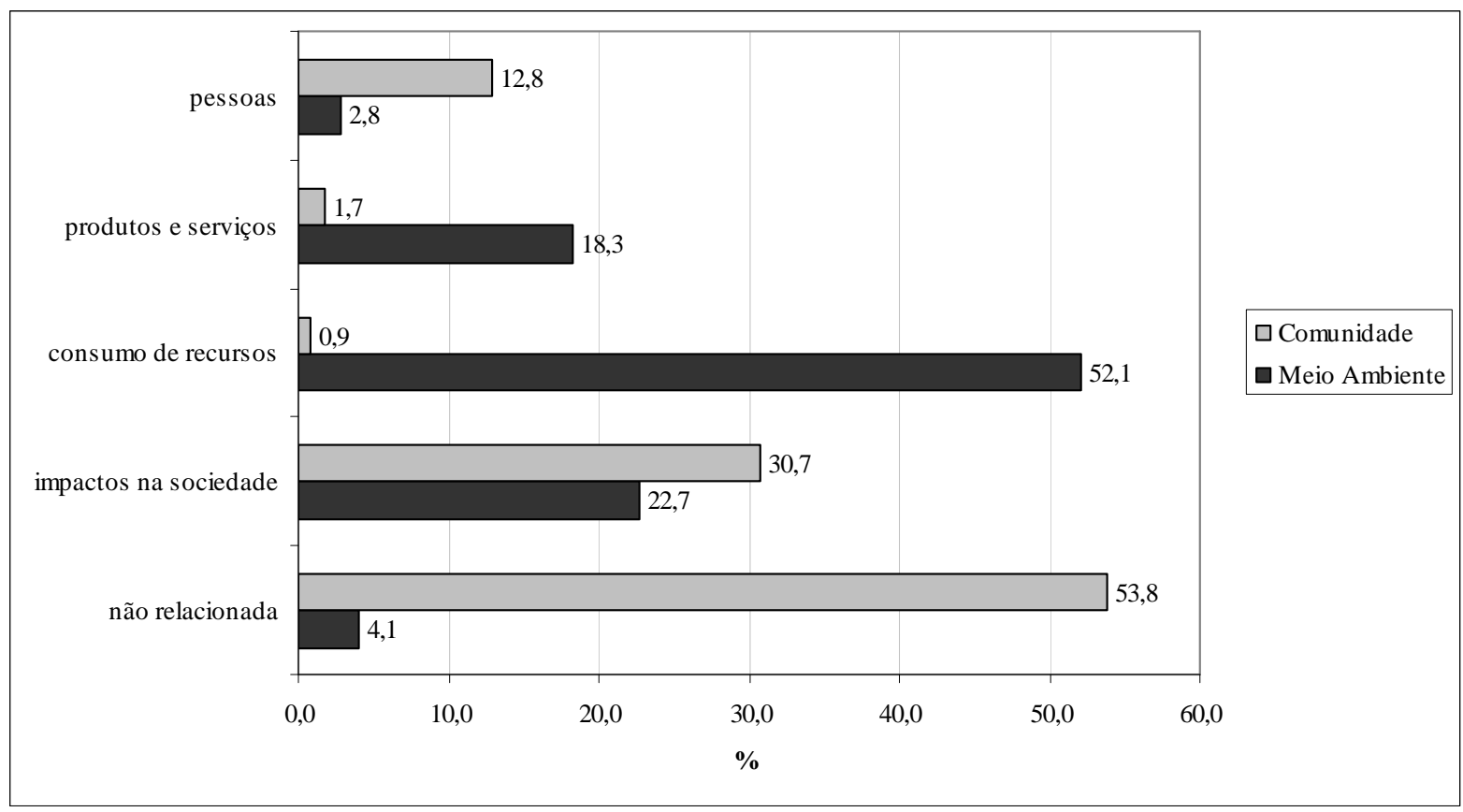

Gráfico 12 - Classificação das informações conforme o relacionamento da prática social com o processo produtivo da companhia, por categoria

É importante diferenciar as informações analisadas de ações sociais e investimentos sociais. As informações analisadas nesta pesquisa empírica incluem informações socioambientais divulgadas pelas empresas da amostra em seus relatórios. Informações não se referem necessariamente a ações das empresas. São ações socioambientais as atitudes práticas das empresas, portanto, declaração de intenções ou valores da companhia não são ações socioambientais. Uma ação será considerada um investimento socioambiental quando houver dispêndio por parte da empresa, mas nem toda ação envolve dispêndio. Apesar de ser usado o termo investimento na literatura de responsabilidade social corporativa, contabilmente, esses gastos são despesas porque há entrega de ativo e não é possível garantir nem quantificar, em bases confiáveis, os benefícios futuros gerados pela decisão. 
Despesas são decréscimos nos benefícios econômicos durante o período contábil sob a forma de saída de recursos ou redução de ativos ou incrementos em passivos, que resultam em decréscimo do patrimônio líquido e que não sejam provenientes de distribuição aos proprietários da entidade. (CPC, 2008a, p. 21).

Uma despesa é reconhecida imediatamente na demonstração do resultado quando um gasto não produz benefícios econômicos futuros ou quando, e na extensão em que os benefícios econômicos futuros não se qualificam, ou deixam de se qualificar, para reconhecimento no balanço patrimonial como um ativo. (ibidem, p. 26)

89. Um ativo é reconhecido no balanço patrimonial quando for provável que benefícios econômicos futuros dele provenientes fluirão para a entidade e seu custo ou valor puder ser determinado em bases confiáveis.

90. Um ativo não é reconhecido no balanço patrimonial quando desembolsos tiverem sido incorridos ou comprometidos, dos quais seja improvável a geração de benefícios econômicos para a entidade após o período contábil corrente. Ao invés, tal transação é reconhecida como despesa na demonstração do resultado. Esse tratamento não implica dizer que a intenção da Administração ao incorrer na despesa não tenha sido a de gerar benefícios econômicos futuros para a entidade ou que a Administração tenha sido mal conduzida. A única implicação é que o grau de certeza quanto à geração de benefícios econômicos para a entidade, após o período contábil corrente, é insuficiente para justificar o reconhecimento de um ativo. (ibidem, p. 24-25).

Logo, para analisar os investimentos socioambientais, é fundamental entender se há dispêndio por parte da empresa. A empresa pode realizar um investimento socioambiental por meio da entrega de dinheiro, estoques, imobilizados ou horas de trabalho de seus empregados. $\mathrm{O}$ Gráfico 13 mostra a classificação das informações por categoria, Comunidade, Meio Ambiente e Recursos Humanos.

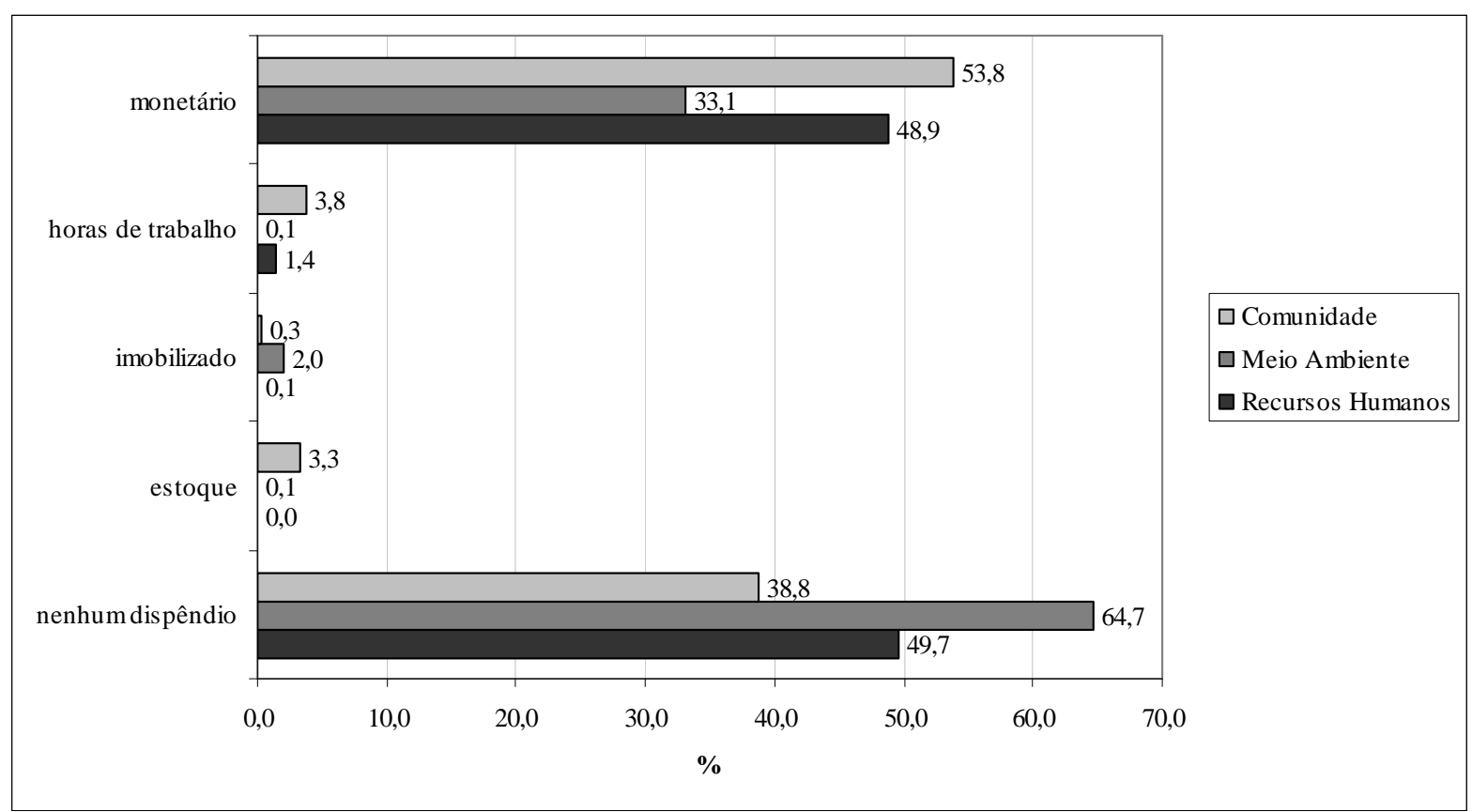

Gráfico 13 - Classificação das informações conforme o dispêndio da companhia, por categoria 
Muitas vezes a informação divulgada nos relatórios analisados não deixava evidentes os dispêndios realizados. Assim, durante a coleta de dados, coube ao pesquisador classificar a existência de gasto e o tipo de ativo entregue, conforme descrição da atividade. Percebe-se que a maior parte das informações divulgadas sobre as categorias Recursos Humanos, Meio Ambiente e Comunidade não se configura como investimento socioambiental. Não foram identificadas outras formas de dispêndio além das incluídas no instrumento de avaliação dos relatórios. Mas, para o caso de ações ambientais, identificou-se a possibilidade de a empresa apresentar ganho líquido, isto é, ganhos superarem os investimentos realizados (por eficiência operacional ou por venda de créditos de carbono), e essa resposta foi incluída nesse quesito.

O Gráfico 14 mostra como investimentos socioambientais são realizados. Em 30\% dos casos, não foi possível identificar quem recebeu o recurso gasto pela empresa, apesar de conhecer o beneficiário final. A falta de informação dos relatórios prejudica, neste quesito, a validação dos critérios adotados. Isto é, pode haver outra forma de transferência não identificada pela falta de detalhamento dos investimentos realizados pelas empresas.

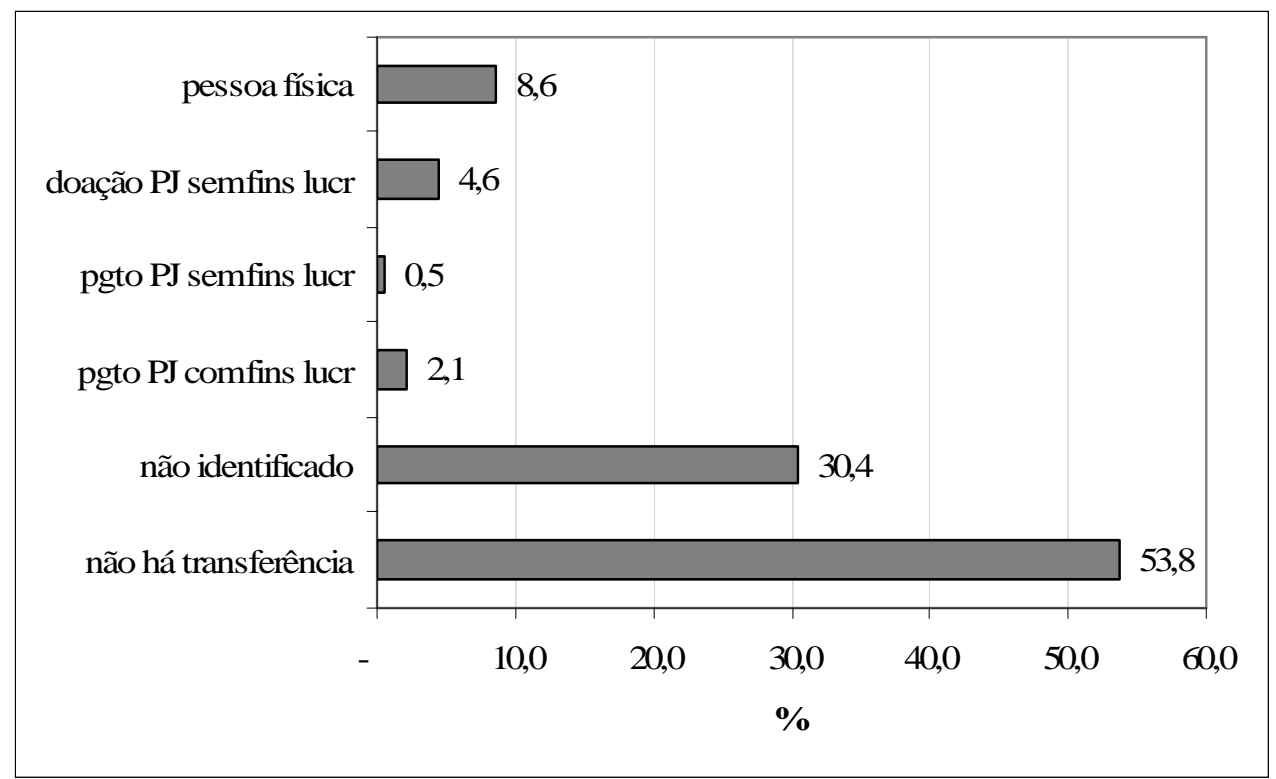

Gráfico 14 - Classificação das informações conforme o meio de transferência de recursos

A pesquisa empírica buscava a identificação dos tipos de investimento socioambiental realizados pelas empresas da amostra. A partir da estrutura adotada por Gray, Kouhy e Lavers (1995a e 1995b) foi desenvolvido o elenco de informações socioambientais com incorporação de informações dos estudos de Macke e Carrion (2006); Sousa Filho e Wanderley (2006) e Rover, Múrcia e Borba (2008). Tal elenco foi adaptado após a realização da pesquisa 
empírica. Dada a diversificação da amostra, espera-se ter alcançado uma tipologia capaz de abranger os diferentes tipos de informação sobre tais investimentos. Para verificar a validade da estrutura desenvolvida, foram realizadas duas entrevistas com pesquisadores da área.

\subsection{Pesquisa Empírica: Validação}

A validação da tipologia de informações socioambientais foi realizada por meio de entrevista semiestruturada com duas pesquisadoras de Responsabilidade Social Corporativa. O roteiro de entrevista (Apêndice 4) foca, especialmente, as categorias Meio Ambiente e Comunidade, pois os investimentos da categoria Recursos Humanos são reconhecidamente classificados na DVA como remuneração do fator de produção trabalho. Os investimentos classificados nas categorias Empresa e Consumidor, conforme já discutido, sempre serão gastos da empresa inerentes ao seu processo produtivo e sua rentabilidade, portanto não se configuram como investimentos socioambientais.

A estrutura apresentada no roteiro de entrevista foi dividida em três partes, A, B e C. A parte A contém a estrutura de classificação das informações socioambientais conforme discutido nos resultados da pesquisa empírica. A parte B questiona o dispêndio realizado e o tipo de ativo entregue, com o objetivo de diferenciar as informações dos investimentos socioambientais. A parte $\mathrm{C}$ questiona o meio de transferência do recurso para a comunidade beneficiada, conforme o último quesito analisado no tópico anterior.

A primeira entrevista foi com a socióloga Anna Maria Medeiros Peliano. Ela é pós-graduada em Política Social pela Universidade de Brasília e já realizou diversas pesquisas sobre políticas sociais e segurança alimentar, inclusive o Mapa da Fome que subsidiou o trabalho de Herbert de Souza na Campanha contra a Fome. É coordenadora-geral da pesquisa Ação Social das Empresas (IPEA/DISOC, 2006) desde a primeira edição que teve início em 1999.

Após analisar a estrutura proposta, Sra. Anna Maria ressaltou que não poderia garantir que as categorias apresentadas esgotam as possibilidades de investimentos socioambientais porque precisaria de mais tempo para a análise. Dada essa limitação, a pesquisadora fez ponderações que serão analisadas a seguir. 
Quanto às categorias Recursos Humanos e Empresa, ela só propôs alteração no nome da categoria Empresas e concordou que os dois grupos constituem-se investimentos com maior interesse para a empresa que para a comunidade. A sugestão foi chamar a categoria Empresa de gestão ou desempenho organizacional, porque "tudo o que está sendo analisado é empresa". Para a estrutura final, o nome da categoria foi alterado para Perfil Organizacional, pois ficaria coerente com sua sugestão, com o Relatório GRI e com a prática observada nos relatórios quando falam da empresa. Ela fez ainda uma ponderação sobre a classificação de treinamentos em meio ambiente para empregados como Recursos Humanos. Ela colocaria essa subcategoria no grupo Meio Ambiente, mesmo sendo voltado para o empregado.

Quanto à categoria Comunidade, a primeira sugestão foi melhorar a definição de realização de projetos da sociedade, explicando o que é a participação efetiva, e a sugestão foi acatada. A segunda sugestão foi evitar usar a questão da imagem ou da troca de divulgação da marca como corte entre as subcategorias. Foi realizada uma adequação das subcategorias, e a questão da imagem ficou apenas para diferenciar doação de patrocínio. Mais duas sugestões foram acatadas: chamar os projetos do governo de programas do governo e excluir as subcategorias doações para campanhas políticas e governo. Segundo a entrevistada, essas subcategorias se enquadrariam no grupo empresa porque não são ações para a comunidade, mas ações políticas para beneficiar a empresa. Vale destacar que as ocorrências de Doações para o governo e Doações para campanhas políticas ocorridas na pesquisa empírica foram apenas declarações de não praticar tais doações. Por fim, mas fundamental para o estudo, foi sugerida a inclusão de uma subcategoria para realização de campanhas de arrecadação de donativos.

Quanto à categoria Meio Ambiente, a primeira sugestão foi separar, na subcategoria 2a (realização de projetos ambientais em parceria com outras instituições, públicas ou privadas), as parcerias com entidades públicas das parcerias com organizações privadas. Entretanto, optou-se por não realizar a alteração porque essa diferenciação já ocorrerá na forma de transferência dos recursos. A segunda sugestão foi rever a redação do item $2 b$ e trocar políticas ambientais por diretrizes ou orientações ambientais, pois política ambiental é muito abrangente e poderia haver sobreposição com os outros itens. Como a ideia dessa subcategoria era separar as informações que não são práticas, a sugestão foi aceita. 
Ela ressaltou a questão da intersecção entre Comunidade e Meio Ambiente e citou que todos os projetos de reciclagem de lixo irão se enquadrar nas duas categorias. Apesar de a afirmativa estar correta, optou-se, neste trabalho, por considerar tais projetos na categoria Comunidade sempre que em curto ou médio prazo houver impacto na renda da comunidade envolvida.

A pesquisa IPEA/DISOC (2006) categoriza qual a atividade que recebe o investimento da empresa: alimentação, assistência social, educação e saúde entre outros. Nesta pesquisa não se julgou relevante tal distribuição, já que não seria possível inferir sobre maior ou menor distribuição de renda em cada atividade. A Sra. Anna Maria corroborou e afirmou que, apesar de haver maior investimento em projetos de alimentação e assistência social, as atividades são interdependentes, o sucesso de alguns projetos de educação depende de projetos de saúde (“às vezes é melhor pra criança cuidar da saúde que saber ler: a criança sabe ler, mas não tem remédio, medicamento, está cheia de sofrimento pela saúde, mas está na escola" ... "escolher o que é melhor entre as atividades é muito complicado").

Quanto ao dispêndio da empresa, ela ressaltou a existência de ações sociais que não envolvem dispêndio, mas não perdem o mérito de ação social. Como exemplo, pode ser citada a Celulose Irani que comprou, em 2007, os cartões de Natal que ela distribuiria da Associação de Pais e Amigos dos Excepcionais (APAE). Haveria a aquisição dos cartões de qualquer maneira na empresa, por isso ela considera uma ação social sem dispêndio, mas optar por produtos que irão financiar a ação social é um tipo de ação social. Assim, foi inserida uma subcategoria com essa ação social no item Comunidade.

Ainda quanto ao dispêndio, a entrevistada sugeriu não usar o termo ganhos líquidos ou especificar que há recuperação dos dispêndios pelos ganhos. Então, o texto foi alterado para "há dispêndios que são compensados e/ou superados pelos ganhos com a mesma atividade". Apesar de inicialmente essa resposta ter sido incluída para atender a investimentos ambientais, conforme discussão na entrevista com a Sra. Anna Maria, há casos de ações sociais que podem se enquadrar nessa resposta.

Quanto aos meios de transferência, a Sra. Anna sugeriu usar os termos pagamento e doação, pois “transferência tem outra conotação". Além disso, ponderou que uma ação social pode ser 
entregue em serviços e sugeriu observar o benefício entregue para a comunidade durante a análise dos investimentos.

A segunda entrevistada, Profa. Dra. Maísa de Souza Ribeiro, é professora associada da Faculdade de Economia, Administração e Contabilidade da Universidade de São Paulo, campus Ribeirão Preto. Contadora com mestrado, doutorado e livre-docência em Ciências Contábeis pela Universidade de São Paulo, ela foi uma das pioneiras no estudo de contabilidade ambiental no Brasil e pesquisa responsabilidade social e a relação das empresas com o meio ambiente desde 1987. É autora do livro Contabilidade Ambiental (RIBEIRO, 2006) e coautora do livro Demonstração do Valor Adicionado: do cálculo da riqueza criada pela empresa ao valor do PIB (DE LUCA et al., 2009).

A profa. Maísa corrobora que as informações pertencentes à categoria Empresa dizem respeito a investimentos com interesse maior para a empresa que para a comunidade. Entretanto, ela alega que a categoria Recursos Humanos é tão importante para a empresa quanto para a comunidade, especialmente a parcela da comunidade que trabalha para a companhia. Ela destacou que a categoria Recursos Humanos deve ser qualificada como investimentos sociais, pois os salários e os benefícios pagos para a empresa são essenciais para a vida dessas pessoas. E ainda, ressaltou a alocação bem definida da categoria na DVA, como distribuição de valor adicionado, dispensando análises mais profundas sobre a categoria neste trabalho.

Quanto à categoria Comunidade, a professora questionou como classificar os projetos nos quais duas empresas dividem a realização de um mesmo projeto e lembrou que as empresas nem sempre mostram em seus relatórios a existência de um parceiro e mais ainda, não evidenciam qual a participação de cada envolvido. De fato, a questão levantada foi notada na análise dos relatórios de sustentabilidade. Nesse caso, os projetos seriam classificados conforme a participação da própria empresa (doação, patrocínio, realização...), e a parceria seria uma informação adicional (e imprescindível) do projeto realizado.

Quanto à categoria Meio Ambiente, sugeriu dividir a subcategoria 2e em investimentos em ativos ambientais e investimentos em ativos de produção limpa, sendo a principal diferença entre eles a essencialidade do ativo de produção limpa no processo produtivo, enquanto o 
ativo ambiental visa exclusivamente à preservação, proteção e recuperação ambiental. A sugestão foi incorporada à estrutura.

Ainda sobre Meio Ambiente, profa. Maísa sugeriu maior especificação na subcategoria 2d ("Impactos dos Produtos e Processos - inclusive uso da água e energia e passivos ambientais") para diminuir sua abrangência e eliminar sobreposições com a subcategoria Sistemas de Gerenciamento Ambiental. A nova definição ficou: "desgaste de recursos naturais durante o processo de produção de produtos e serviços [inclui uso da água e energia e passivos ambientais]”.

Quanto ao dispêndio na categoria Meio Ambiente, a professora levantou a dificuldade de separar os sistemas de gerenciamento ambiental dos sistemas de produção. Apesar de a classificação ser essencial para diferenciar os investimentos ambientais dos investimentos em processo produtivo, as empresas não deixam tais diferenças evidentes na informação divulgada.

A professora concordou com a necessidade de se classificarem as informações quanto ao dispêndio e quanto ao meio de transferência dos recursos, pois assim será divulgada a participação efetiva da empresa. Se as empresas divulgarem o tipo de dispêndio e o meio de realização do investimento, "ainda que não haja valores, haverá um cenário muito mais completo do que o de hoje que é meramente qualitativo".

Segundo profa. Maísa, a responsabilidade social corporativa é um conceito em evolução, por isso, ela ressaltou em cada categoria que a tipologia criada atende ao conceito atual de RSC, mas com a evolução das práticas socioambientais, novas subcategorias poderão surgir.

\subsection{Tipologia dos Investimentos Socioambientais}

As alterações sugeridas nas entrevistas foram incluídas conforme o tópico anterior, e o Quadro 10 mostra a tipologia final das informações socioambientais divulgadas nos Relatórios de Sustentabilidade das empresas analisadas. 
Quadro 10 - Tipologia Final das Informações do Relatório de Sustentabilidade

\begin{tabular}{|c|c|}
\hline & parte A - Tipologia das Informações dos Relatórios de Sustentabilidade \\
\hline \multirow{11}{*}{$\begin{array}{l}\text { 1. Recursos } \\
\text { Humanos }\end{array}$} & Dados sobre quantidades de empregados [inclusive por diferentes idades, etnias e gêneros] \\
\hline & Avaliação de desempenho e ambiente de trabalho \\
\hline & $\begin{array}{l}\text { c. Prêmios, benefícios, incentivos, planos de carreira e políticas salariais [exceto participação nos lucros e } \\
\text { prêmios em ações] }\end{array}$ \\
\hline & $\begin{array}{l}\text { d. Treinamentos e cursos de capacitação para empregados [exceto em temas relacionados ao meio } \\
\text { ambiente, saúde e segurança no trabalho] }\end{array}$ \\
\hline & Previdência dos empregados \\
\hline & Emprego de minorias e/ou deficientes \\
\hline & Saúde e segurança no trabalho [inclui treinamentos em temas de meio ambiente] \\
\hline & $\begin{array}{l}\text { h. Engajamento dos empregados nas decisões da empresa [ações que incentivem a participação de } \\
\text { empregados nos processo decisórios e/ou informem os empregados sobre as decisões da empresa] }\end{array}$ \\
\hline & $\begin{array}{l}\text { i. Participação nos lucros, prêmios em ações ou opções de compra de ações da empresa, incentivos para } \\
\text { compra de ações [exceto para diretoria] }\end{array}$ \\
\hline & Direitos do trabalhador, Direitos Humanos e Trabalho Infantil \\
\hline & Informações de conjuntura com seus impactos nos empregados da empresa. \\
\hline \multirow{8}{*}{ 2. Meio Ambiente } & $\begin{array}{l}\text { a. Realização de projetos ambientais em parceria com outras instituições, públicas ou privadas [quando for } \\
\text { evidente que não há vínculo da atividade econômica da empresa com o projeto realizado] }\end{array}$ \\
\hline & $\begin{array}{l}\text { b. Diretrizes Ambientais da empresa [inclui informações de conjuntura com seus impactos nas decisões } \\
\text { tomadas pela empresa] }\end{array}$ \\
\hline & $\begin{array}{l}\text { c. Sistemas de Gerenciamento Ambiental [procedimentos incluídos no processo operacional da empresa } \\
\text { com o objetivo de minimizar o impacto dos resíduos gerados pela empresa ao meio ambiente] }\end{array}$ \\
\hline & $\begin{array}{l}\text { d. Desgaste de recursos naturais durante o processo de produção de produtos e serviços [inclui uso da água } \\
\text { e energia e passivos ambientais] }\end{array}$ \\
\hline & $\begin{array}{l}\text { e. Investimentos em ativos de produção limpa [considerar ativos de produção limpa os bens e direitos de } \\
\text { longa duração essenciais ao processo produtivo e que visem a melhorar a interação entre o processo produtivo } \\
\text { e o meio ambiente] }\end{array}$ \\
\hline & $\begin{array}{l}\text { f. Investimentos em ativos ambientais [considerar ativo ambiental os bens e direitos que tenham } \\
\text { capacidade de geração de benefício econômico em períodos futuros e que visem exclusivamente à preservação, } \\
\text { proteção e recuperação ambiental (RIBEIRO, 2006, p. 61)] }\end{array}$ \\
\hline & $\begin{array}{l}\text { g. Educação, Pesquisa e Treinamento [exceto para empregados da empresa; quando for evidente a relação } \\
\text { do tema com a atividade econômica da empresa] }\end{array}$ \\
\hline & Mercado de Créditos de Carbono \\
\hline \multirow{7}{*}{ 3. Comunidade } & $\begin{array}{l}\text { a. Realização de projetos sociais na comunidade [quando a participação da empresa ocorrer não apenas } \\
\text { com aporte de recursos, mas também com a organização e/ou execução do projeto] }\end{array}$ \\
\hline & Doações para projetos sociais da comunidade \\
\hline & Doações para programas sociais do governo \\
\hline & $\begin{array}{l}\text { d. Voluntariado empresarial quando a participação da empresa envolver algum tipo de investimento [por } \\
\text { exemplo, em horas de trabalho ou transporte dos voluntários] }\end{array}$ \\
\hline & $\begin{array}{l}\text { e. Patrocínios à educação, artes e esportes [quando há o custeio da atividade com a divulgação explícita da } \\
\text { marca da empresa no projeto] }\end{array}$ \\
\hline & $\begin{array}{l}\text { f. Realização de campanhas de arrecadação de donativos [quando a empresa faz a divulgação, recolhe e } \\
\text { entrega os donativos à comunidade] }\end{array}$ \\
\hline & $\begin{array}{ll}\text { g. } & \text { Conflitos entre a empresa ou seu processo operacional e a comunidade externa } \\
\text { h. } & \text { Aquisição de produtos que financiam projetos sociais para serem usados no processo operacional da } \\
\text { empresa }\end{array}$ \\
\hline \multirow{12}{*}{$\begin{array}{c}\text { 4. Perfil } \\
\text { Organizacional }\end{array}$} & Desempenho Financeiro \\
\hline & $\begin{array}{l}\text { b. Desempenho Mercadológico [informações sobre crescimento da empresa, participação de mercado, } \\
\text { campanhas publicitárias etc.] }\end{array}$ \\
\hline & $\begin{array}{l}\text { c. Processo operacional [quando a informação refere-se aos produtos ou ao processo de produção da } \\
\text { empresa em sua operação principal - considerar informações de empregados e meio ambiente nos tópicos } \\
\text { anteriores] }\end{array}$ \\
\hline & $\begin{array}{l}\text { d. Desempenho Socioambiental [apenas quando a empresa declara prêmios recebidos pela atuação } \\
\text { socioambiental da empresa como um todo] }\end{array}$ \\
\hline & $\begin{array}{l}\text { e. Políticas, valores e estratégias da empresa [quando relacionada apenas à operação da empresa e seu } \\
\text { contexto - não envolvem políticas e valores com empregados, meio ambiente ou ações com a comunidade] }\end{array}$ \\
\hline & Desenvolvimento ou venda de produtos com forte apelo socioambiental \\
\hline & $\begin{array}{l}\text { g. Adoção de objetivos globais de sustentabilidade [declarações de anuência a políticas nacionais ou } \\
\text { globais - não desenvolvidas pela empresa - como: Objetivos do Milênio, Princípios do Equador, Pacto Global } \\
\text { etc.] }\end{array}$ \\
\hline & Estrutura de governança corporativa e relações com acionistas \\
\hline & Segurança do produto e para o consumidor \\
\hline & Serviços de atendimento ao consumidor \\
\hline & Atendimento especial para consumidores deficientes e idosos \\
\hline & Relação com Fornecedores [inclui treinamentos, brindes e incentivos para fornecedores] \\
\hline
\end{tabular}


Para resolver o problema de pesquisa desta tese, é necessário estudar os investimentos socioambientais e sua relação com o conceito de valor adicionado. No estudo empírico, ficou evidente que as informações da categoria Perfil Organizacional não se configuram, em nenhuma hipótese, como investimento socioambiental. Tal conclusão foi validada nas entrevistas realizadas. Já a categoria Recursos Humanos se configura como investimento social, mas já tem sua relação com o conceito de valor adicionado bem definida: remuneração do fator de produção trabalho, logo é distribuição de valor adicionado. Portanto, as categorias Recursos Humanos e Perfil Organizacional serão excluídas da análise a partir deste ponto, pois o problema de pesquisa desta tese não abrange tais informações.

Assim, serão avaliadas, no próximo capítulo, as categorias Comunidade e Meio Ambiente. Para finalizar a tipologia, é necessário evidenciar as possibilidades de dispêndio e o meio de transferência dos recursos. O Quadro 11 mostra as possibilidades de dispêndio para cada categoria, e o Quadro 12, os meios de transferência dos recursos. A diferenciação das formas de dispêndio entre as categorias deve-se ao fato de as informações de investimentos ambientais estarem muito relacionadas com o processo operacional. E para caracterizar o investimento ambiental, é fundamental separá-lo do processo operacional. As formas sem dispêndio foram excluídas, pois não representam investimentos socioambientais.

Quadro 11 - Tipologia Final dos Dispêndios realizados nos Investimentos Socioambientais

\begin{tabular}{|c|c|}
\hline & parte B - Carcaterização do dispêndio da empresa \\
\hline \multirow{6}{*}{ Meio Ambiente } & I. a atividade envolve dispêndios para a empresa já característicos do processo produtivo \\
\hline & $\begin{array}{l}\text { II. a atividade envolve dispêndios monetários por parte da empresa adicionalmente àqueles inerentes ao processo } \\
\text { produtivo }\end{array}$ \\
\hline & $\begin{array}{l}\text { III. a atividade envolve dispêndios para a empresa em horas de trabalho adicionais àquelas inerentes ao processo } \\
\text { produtivo }\end{array}$ \\
\hline & $\begin{array}{l}\text { IV. a atividade envolve dispêndios de recursos do imobilizado da empresa adicionalmente àqueles inerentes ao } \\
\text { processo produtivo }\end{array}$ \\
\hline & V. a atividade envolve dispêndios de estoques da empresa adicionalmente àqueles inerentes ao processo produtivo \\
\hline & VI. a atividade envolve dispêndios que são recuperados e/ou superados pelas receitas da atividade (ganho líquido) \\
\hline \multirow{5}{*}{ Comunidade } & I. a atividade envolve dispêndio monetário direto por parte da empresa \\
\hline & II. a atividade envolve dispêndio para a empresa em horas de trabalho dos empregados \\
\hline & III. a atividade envolve dispêndio de recursos do imobilizado da empresa \\
\hline & IV. a atividade envolve dispêndio de estoques da empresa \\
\hline & V. a atividade envolve dispêndios que são recuperados e/ou superados pelas receitas da atividade (ganho líquido) \\
\hline
\end{tabular}


Quadro 12 - Tipologia Final dos Meios de Transferência de Recursos nos Investimentos Socioambientais

\begin{tabular}{|c|c|}
\hline & parte C - Caracterização da transferência de recursos pela empresa \\
\hline \multirow{5}{*}{ Meio Ambiente } & i. ocorre doação direta para pessoas físicas \\
\hline & ii. ocorre doação para uma pessoa jurídica sem fins lucrativos \\
\hline & iii. ocorre pagamento para uma pessoa jurídica sem fins lucrativos por produto ou serviço adquirido \\
\hline & iv. ocorre pagamento para uma pessoa jurídica com fins lucrativos por produto ou serviço adquirido \\
\hline & v. ocorre doação para programas de governo \\
\hline \multirow{6}{*}{ Comunidade } & i. $\quad$ ocorre doação direta para pessoas físicas \\
\hline & ii. ocorre doação para uma pessoa jurídica sem fins lucrativos em troca de incentivo fiscal \\
\hline & iii. ocorre doação para uma pessoa jurídica sem fins lucrativos sem se beneficiar de incentivos fiscais \\
\hline & iv. ocorre pagamento para uma pessoa jurídica sem fins lucrativos por produto ou serviço adquirido \\
\hline & v. ocorre pagamento para uma pessoa jurídica com fins lucrativos por produto ou serviço adquirido \\
\hline & vi. ocorre doação para programas do governo \\
\hline
\end{tabular}




\section{INVESTIMENTOS SOCIOAMBIENTAIS E VALOR ADICIONADO}

A questão central deste trabalho requer definir se os investimentos socioambientais devem ser tratados como redução na formação do valor adicionado ou remuneração dos fatores de produção (distribuição de valor adicionado). Então, este capítulo traz uma análise teórica de valor adicionado e remuneração dos fatores de produção e sua relação com investimentos socioambientais. Em seguida, o problema é analisado sob a ótica do cálculo do PIB brasileiro pelo Instituto Brasileiro de Geografia e Estatística (IBGE).

\subsection{Valor Adicionado X Remuneração dos Fatores de Produção}

$\mathrm{O}$ valor adicionado mostra a renda gerada por uma unidade produtiva à economia. $\mathrm{O}$ IBGE define valor adicionado como o valor agregado por uma atividade aos bens e serviços consumidos no processo produtivo. "É a contribuição ao produto interno bruto pelas diversas atividades econômicas, obtida pela diferença entre o valor de produção e o consumo intermediário absorvido por essas atividades" (IBGE, 2008b, p. 100).

Todo o valor adicionado gerado por um país será igual a sua renda após os efeitos das transações com outros países. A renda decorre da remuneração dos fatores de produção. Conforme visto anteriormente, incluem-se na renda: os salários (remuneração do trabalho), os juros (remuneração do capital de empréstimo), os lucros (remuneração do capital de risco) e os aluguéis (remuneração da propriedade física de bens de capital) (SIMONSEN; CYSNE, 2007, p. 147). Uma parcela dessas remunerações é entregue ao governo para financiamento das atividades públicas, com isso o governo também figura entre as partes que recebem distribuição do valor adicionado. Pode haver, geralmente por parte do governo, redistribuição da renda, quando o governo tira a renda de alguém e a transfere a outro (STIGLITZ, 2000, p. $33)$.

Assim, a distribuição de valor adicionado irá se caracterizar quando houver remuneração dos fatores de produção (capital, terra ou trabalho) ou quando houver um redirecionamento dessa 
remuneração para outros beneficiários (governo). Isso implica dizer que quando a empresa investe em ações não relacionadas com seu processo produtivo que tenham como beneficiárias pessoas que não tenham alugado os serviços do capital, terra ou trabalho à empresa, haverá distribuição secundária da renda. Logo, para as empresas investirem em ações socioambientais com benefício para a comunidade haverá redução na remuneração de capital, terra e trabalho ou redução na parcela de valor adicionado entregue ao governo.

Sob a ótica contábil, isto é, pela DVA (Quadro 13), necessariamente os investimentos socioambientais devem ser classificados como formação ou distribuição do valor adicionado, pois aparecem como despesa na DRE e todas as despesas da DRE são computadas na elaboração da DVA. Na estrutura atual da DVA, pode-se afirmar que todas as despesas da empresa serão deduções na formação do valor adicionado com exceção das despesas com pessoal, impostos, juros e aluguel, ou seja, todas as despesas exceto aquelas que se caracterizam como remuneração dos fatores de produção (destinação da renda).

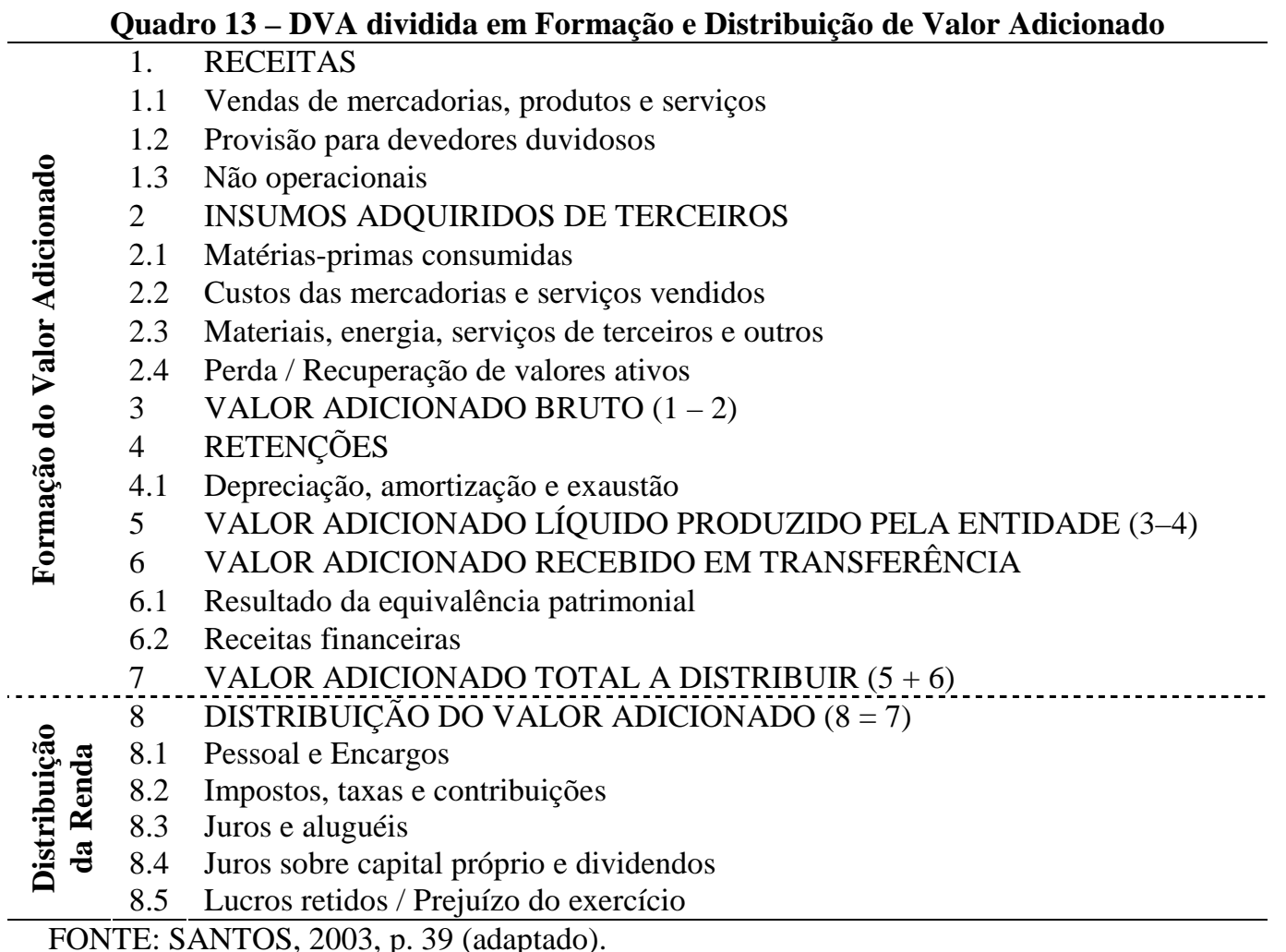

Para analisar a adequada alocação dos investimentos socioambientais na DVA, deve-se entender a relação de tais investimentos com o processo produtivo da empresa, pois tanto o 
conceito de valor adicionado quanto o conceito de remuneração dos fatores estão associados ao processo produtivo.

O estudo empírico apresentado no capítulo 4 separou as informações divulgadas pelas empresas em seus Relatórios de Sustentabilidade em quatro grandes grupos: Recursos Humanos, Meio Ambiente, Comunidade e Perfil Organizacional. Este último não representa investimentos socioambientais. Recursos humanos, conforme já discutido, referem-se à remuneração do trabalho como fator de produção, e sua posição na DVA é bem definida. Os investimentos em meio ambiente e na comunidade serão analisados aqui.

As informações relacionadas com meio ambiente, analisadas no estudo empírico, ficaram categorizadas conforme Quadro 14. A subcategoria 'b', na maior parte dos casos analisados, não envolve dispêndio, portanto, não se caracteriza como investimento ambiental. As subcategorias 'c', 'd' e 'e', pela própria definição, mostram-se relacionadas ao processo produtivo. Os investimentos relacionados às categorias 'c' e 'e' deverão aparecer na DRE, principalmente, como despesa de depreciação, enquanto o investimento relacionado à categoria 'd' deverá aparecer como parte do custo dos produtos vendidos ou como despesas operacionais. Esses investimentos representam o consumo de recursos (água, energia, equipamentos etc.) no processo produtivo, isto é, são bens e serviços utilizados como insumos, logo, conceitualmente se caracterizam como redução do valor adicionado.

Quadro 14 - Tipologia das informações na categoria Meio Ambiente

\begin{tabular}{|l|l|}
\hline \multirow{2}{*}{ Meio Ambiente } & $\begin{array}{l}\text { a. Realização de projetos ambientais em parceria com outras instituições, públicas ou privadas [quando for } \\
\text { evidente que não há vínculo da atividade econômica da empresa com o projeto realizado] }\end{array}$ \\
\hline $\begin{array}{l}\text { b. Diretrizes Ambientais da empresa [inclui informações de conjuntura com seus impactos nas decisões tomadas } \\
\text { pela empresa] }\end{array}$ \\
$\begin{array}{l}\text { c. Sistemas de Gerenciamento Ambiental [procedimentos incluídos no processo operacional da empresa com o } \\
\text { objetivo de minimizar o impacto dos resíduos gerados pela empresa ao meio ambiente] }\end{array}$ \\
$\begin{array}{l}\text { d. Desgaste de recursos naturais durante o processo de produção de produtos e serviços [inclui uso da água e } \\
\text { energia e passivos ambientais] }\end{array}$ \\
$\begin{array}{l}\text { e. Investimentos em ativos de produção limpa [considerar ativos de produção limpa os bens e direitos de longa } \\
\text { duração essenciais ao processo produtivo e que visem a melhorar a interação entre o processo produtivo e o meio } \\
\text { ambiente] } \\
\text { f. Investimentos em ativos ambientais [considerar ativo ambiental os bens e direitos que tenham capacidade de } \\
\text { geração de benefício econômico em períodos futuros e que visem exclusivamente à preservação, proteção e } \\
\text { recuperação ambiental (RIBEIRO, 2006, p. 61)] }\end{array}$ \\
\hline $\begin{array}{l}\text { g. Educação, Pesquisa e Treinamento [exceto para empregados da empresa; quando for evidente a relação do } \\
\text { tema com a atividade econômica da empresa] } \\
\text { h. Mercado de Créditos de Carbono }\end{array}$ \\
\hline
\end{tabular}

As subcategorias 'a', 'f' e 'g' (Quadro 15) não mostram relação direta com o processo produtivo. Entretanto, pode haver relação com as externalidades negativas geradas pela empresa para o meio ambiente. No capítulo anterior, foi apresentado o caso da Companhia de 
Bebidas Ipiranga que realiza programas de educação ambiental em escolas públicas. O programa é um incentivo à reciclagem: a empresa coloca tambores de reciclagem nas escolas e depois "compra" o material coletado por meio de doações (computadores, móveis escolares, passeios, etc.). A maior parte do material reciclado é oriunda dos produtos vendidos pela empresa. Na verdade, a empresa está recolhendo o lixo que ela gerou. Isso é um custo estrutural do negócio, não há característica de distribuição do valor adicionado.

Ao analisar o processo produtivo, deve-se entender o processo como um todo, isto é, observar a cadeia produtiva da empresa e o ciclo de vida dos produtos vendidos. Apesar de o conceito econômico caracterizar o consumo final como o fim do processo produtivo, essa ideia já vem mudando na sociedade atual. O estado de São Paulo por meio da aprovação da Lei 13.576/2009 já responsabiliza os fabricantes pelos resíduos dos produtos eletrônicos. Em âmbito federal, o Projeto de Lei 1.991/2007 traz uma política para tratamento dos resíduos sólidos e conceitua o produto por seu ciclo de vida.

Nos relatórios analisados no estudo empírico, ações de reflorestamento foram divulgadas como investimento ambiental, mesmo quando havia obrigatoriedade legal. Se há obrigatoriedade legal, certamente, há prejuízo para a flora causado pela atividade produtiva. Nesse caso, a empresa está repondo insumos já utilizados no processo produtivo.

Portanto, ao analisar os investimentos ambientais, deve-se verificar a relação do investimento com o processo produtivo, antes de qualificá-lo como distribuição de valor adicionado. Conforme o conceito de valor adicionado, apenas os casos de investimentos ambientais que não representem, em nenhuma vertente, consumo de insumos para o processo produtivo nem compensação de prejuízos causados por esse processo poderiam ser qualificados como distribuição de valor adicionado.

Por fim, a subcategoria 'h', Mercados de Crédito de Carbono, envolve a comercialização de créditos de carbono obtidos porque o processo produtivo da empresa consegue capturar $\mathrm{CO}_{2}$ equivalente do meio ambiente. Dois aspectos descaracterizam a distribuição de valor adicionado nesse caso. O primeiro é a receita obtida pela venda dos créditos. A empresa não realiza um investimento ambiental (investimentos para mudanças no processo produtivo são classificadas na subcategoria 'e' do Quadro 14), realiza gastos para obtenção de receita. Assim, é possível entender a comercialização de créditos de carbono como uma atividade 
comercial da empresa com receitas e despesas ou como redução nos custos do processo operacional. O segundo aspecto é o envolvimento com processo produtivo, isto é, ainda que haja dispêndio na operação, haverá relação com a produção. Portanto, essa subcategoria caracteriza-se como formação do valor adicionado da companhia.

Quadro 15 - Tipologia das informações na categoria Comunidade

\begin{tabular}{|c|c|}
\hline \multirow{8}{*}{ Comunidade } & $\begin{array}{l}\text { a. Realização de projetos sociais na comunidade [quando a participação da empresa ocorrer não apenas } \\
\text { com aporte de recursos, mas também com a organização e/ou execução do projeto] }\end{array}$ \\
\hline & Doações para projetos sociais da comunidade \\
\hline & Doações para programas sociais do governo \\
\hline & $\begin{array}{l}\text { d. Voluntariado empresarial quando a participação da empresa envolver algum tipo de investimento [por } \\
\text { exemplo, em horas de trabalho ou transporte dos voluntários] }\end{array}$ \\
\hline & $\begin{array}{l}\text { e. Patrocínios à educação, artes e esportes [quando há o custeio da atividade com a divulgação explícita da } \\
\text { marca da empresa no projeto] }\end{array}$ \\
\hline & $\begin{array}{l}\text { f. Realização de campanhas de arrecadação de donativos [quando a empresa faz a divulgação, recolhe e } \\
\text { entrega os donativos à comunidade] }\end{array}$ \\
\hline & Conflitos entre a empresa ou seu processo operacional e a comunidade externa \\
\hline & $\begin{array}{l}\text { h. Aquisição de produtos que financiam projetos sociais para serem usados no processo operacional da } \\
\text { empresa }\end{array}$ \\
\hline
\end{tabular}

Na tipologia da categoria Comunidade (Quadro 15), a aquisição de produtos que financiam projetos sociais para serem usados no processo operacional da empresa é uma ação social porque beneficia a comunidade, mas não é sempre um investimento social porque não gera despesa adicional para a empresa. Quando a empresa, por exemplo, compra uniformes produzidos pela oficina de costura de uma clínica de reabilitação, ela está realizando ação social porque ajuda a financiar a clínica, mas não há despesa, pois a compra de uniformes é parte do processo operacional. Pode-se argumentar que há uma diferença de custos entre uma indústria de uniformes e a oficina de costura, e se a empresa paga mais caro para comprar da oficina, haveria investimento social (diferença paga a maior, pela ação social). É verdade, e nesse caso, se houver informação para mensurar o investimento, é possível considerá-lo como uma forma de distribuição secundária de renda para a comunidade, caso contrário, não haverá investimento social, e o gasto é classificado em insumos usados no processo produtivo.

Outra subcategoria, 'h', abrange conflitos entre a comunidade e a empresa por seu processo operacional. São exemplos: invasão de terras produtivas de empresas de papel e celulose ou avanço da tecnologia e processo produtivo de empresas de transporte para terras indígenas. Nessa subcategoria, só haverá investimento social se houver dispêndio para a empresa e se houver evidente benefício para a comunidade. Pois, em alguns casos, como a desocupação de terras invadidas, os dispêndios poderão gerar apenas benefícios para a empresa. 
As subcategorias 'a', 'b', 'c' e 'd' representam doações para projetos da comunidade e podem ser tratadas de modo conjunto para efeito de avaliação da participação na DVA. Em todos os casos, existe doação de recursos da empresa. Há um sacrifício não relacionado ao processo produtivo que representa redução de remuneração para governo, empregados e/ou proprietários de capital. Portanto, há distribuição secundária da renda. É importante ressaltar que há distribuição, mas não é possível saber o efeito distributivo disso, ou seja, não há garantias de melhoria na estrutura de distribuição de renda do país. O ideal seria as empresas avaliarem o impacto social de suas ações, mas segundo a entrevistada do estudo empírico, Sra. Anna Peliano, poucas organizações o fazem.

A subcategoria 'e' traz os patrocínios que, por definição, têm finalidade de divulgação da marca da empresa, então é uma espécie de propaganda. Assim, o investimento será relacionado ao processo produtivo e classificado na DVA como serviços adquiridos de terceiros, como ocorre com as despesas de publicidade. Em alguns casos, a intenção da empresa não é a divulgação da marca como propaganda, pois o impacto é pequeno, mas associar a imagem da empresa a um projeto social local ou utilizar um incentivo fiscal. Quando há aproveitamento de incentivo fiscal, a empresa está usando uma parte do imposto devido para o governo para realizar o patrocínio. Então, na DVA, os patrocínios incentivados devem ser tratados como distribuição de valor para o governo.

A subcategoria ' $f$ ' traz os casos de campanha de arrecadação de donativos. Esse caso é complexo porque quem doa são os clientes ou empregados da empresa, o investimento realizado pela companhia acontece para divulgação da campanha. Em alguns casos, o valor arrecadado nem é contabilizado porque não passa pela empresa. Quando o recurso recebido por meio de ações de responsabilidade social não transita pela contabilidade da empresa, não aparece na DRE, logo também não deverá compor a DVA que evidencia a distribuição de valor adicionado da companhia.

Um exemplo dessa subcategoria é o projeto Criança Esperança promovido pela Rede Globo. Nesse caso, a empresa é responsável apenas pela divulgação do evento, ou seja, os recursos doados não passam pela empresa. Segundo informação dada durante a divulgação do projeto, o valor arrecadado é depositado diretamente na conta corrente da Organização das Nações Unidas para a Educação, a Ciência e a Cultura (UNESCO). Portanto, a empresa tem gastos com a divulgação da campanha e com a realização do evento (show que acontece em um fim 
de semana para estimular a arrecadação), mas nenhum valor é entregue para a sociedade por esse projeto (a empresa tem outros projetos sociais pela Fundação Roberto Marinho que não estão em análise). A empresa apresenta os projetos beneficiados pelo Criança Esperança associados à sua imagem, mas não há transferência direta de recursos divulgada ${ }^{16}$. Existe distribuição de valor adicionado nesse caso? Não. Sem dúvida, o projeto é louvável e gera muitos benefícios sociais, mas não há distribuição de valor adicionado pela Rede Globo. Há distribuição secundária da renda pela UNESCO, pois ela recebe as doações de pessoas que, aparentemente, não são as mesmas beneficiadas pelo projeto, logo, ocorre transferência de fluxos de benefícios. Mas a Rede Globo não está envolvida diretamente nesse processo porque os valores não passam por sua contabilidade, e os gastos realizados pela Rede Globo para a campanha são típicos de seu processo produtivo.

Apesar de a análise ser coerente com o que parece ocorrer na contabilidade da Rede Globo com a realização do projeto, não seria um contrassenso pensar que o maior projeto de arrecadação de donativos do país não se define como distribuição de valor adicionado para sua organizadora? É importante haver análise detalhada pelo contador da empresa, a fim de identificar a relação dos investimentos realizados com o processo produtivo. O projeto social pode representar fonte de receita lucrativa para a empresa se houver venda de anúncios publicitários durante os shows e haveria, então, uma estratégia ganha-ganha, conforme já discutido. Vale destacar que não distribuir valor adicionado não invalida a ação social que gera benefícios para a comunidade.

Quanto ao dispêndio, a categoria Meio Ambiente apresenta a separação entre investimentos relacionados ao processo produtivo e os gastos adicionais. Essa separação é necessária porque somente aqueles dispêndios adicionais ao processo produtivo poderão ser considerados distribuição de valor adicionado. Tanto a categoria Meio Ambiente quanto Comunidade apresentam o dispêndio segregado conforme o tipo de recurso investido. Quando o dispêndio ocorre em horas de trabalho dos empregados, atualmente, aparece na DVA como remuneração do fator de produção trabalho, ou seja, distribuição de valor para empregados.

\footnotetext{
${ }^{16} \mathrm{Na}$ verdade, não foi possível identificar se os gastos com a divulgação e realização do evento são custeados pela Rede Globo ou pela Fundação Roberto Marinho. A Rede Globo pode doar o espaço na programação para a Fundação Roberto Marinho e nesse caso, para a Rede Globo, o projeto seria uma doação para projetos sociais da comunidade (subcategoria 'b') e não uma campanha de arrecadação de donativos. Ou ainda a emissora pode realizar a campanha de arrecadação, mas obter receitas com a venda de anúncios durante o show, como qualquer outro programa e, nesse caso, realmente não há distribuição de valor adicionado.
} 
Quando o dispêndio de recursos do imobilizado é apenas um desgaste, e não entrega do bem (empréstimo ou uso do bem em ações socioambientais), ele é incluído nos gastos de depreciação e aparece como retenção do valor adicionado na DVA, portanto participa da formação do valor adicionado reduzindo-o. O dispêndio com entrega de ativo, seja estoque, imobilizado ou caixa, atualmente é registrado como insumo adquirido de terceiros, logo, é computado na formação do valor adicionado, não como distribuição. Nesse caso, se o investimento socioambiental não fosse contabilizado na DVA, o valor adicionado seria maior, aumentando o valor a ser distribuído entre os fatores de produção e o governo. Fica evidente que a decisão de investir em ações para a comunidade ou o meio ambiente reduz a remuneração desses grupos.

Pela lógica atual da DVA, o meio de transferência dos recursos terá impacto na classificação do investimento socioambiental somente no caso dos incentivos fiscais. A DVA considera o conceito e não a natureza jurídica de quem recebe o valor adicionado. Assim, não há diferença na distribuição de valor adicionado se o acionista da empresa (remunerado pelo capital empregado) possui personalidade jurídica ou não ou se possui finalidade de lucro ou não. $\mathrm{O}$ incentivo fiscal recebido fará diferença porque, nesse caso, não há um novo dispêndio da empresa, apenas um redirecionamento do recurso. A empresa deixa de pagar parte do imposto de renda para o governo, mas entrega esse valor para um projeto social. Não há redução da carga tributária da empresa se ela optar por não investir.

Portanto, apesar de a teoria de Responsabilidade Social Corporativa mostrar o interesse próprio das entidades em seus investimentos socioambientais, a sociedade pode também ser beneficiada. É claro que a sociedade tem o papel de fiscalizar porque a empresa pode “explorar" a causa social ou ambiental. Mas o fato de usar ações socioambientais como marketing da instituição ou mesmo como forma de obtenção direta de receitas não invalida o benefício gerado para a sociedade. As empresas, então, não devem ser martirizadas porque buscam maximizar seu valor para os acionistas quando realizam investimentos socioambientais, mas também não devem ser idolatradas porque são socioambientalmente responsáveis.

Para analisar a distribuição de valor adicionado por um investimento socioambiental não é suficiente avaliar o motivo do investimento. É importante avaliar se o impacto direto na sociedade é uma "compensação" das externalidades geradas pela própria empresa ou um 
benefício adicional para a comunidade; avaliar o dispêndio realizado; e avaliar como esse investimento é realizado para saber se há contabilização na empresa e se há recebimento de incentivo fiscal. Vale ressaltar que o ideal seria a realização de uma avaliação de impactos sociais dos programas desenvolvidos por cada empresa investidora, isto é, a empresa deveria medir a variação de renda gerada por seus investimentos na comunidade. Mas a relação custobenefício dessa avaliação pode não ser viável para a empresa.

Com isso, encerra-se a análise conceitual proposta neste capítulo. Conclui-se que há possibilidade de a empresa realizar distribuição de valor adicionado com os investimentos socioambientais. Mais especificamente, as empresas realizam distribuição secundária da renda. Resta avaliar como se consideram esses investimentos no cálculo do produto nacional.

\subsection{Análise sob a ótica do PIB brasileiro (Metodologia IBGE)}

O produto nacional pode ser mensurado pela ótica do produto, pela ótica da renda e pela ótica do dispêndio. Conforme Gremaud e Toneto Jr. (2007, p. 205), “a igualdade entre produto e renda decorre do fato de que o valor adicionado em cada etapa produtiva corresponde justamente à remuneração dos fatores envolvidos naquela etapa". Já a igualdade entre produto e dispêndio vem do próprio conceito de dispêndio que engloba todos os destinos possíveis do produto. Mais especificamente, o produto de um país pode se destinar ao consumo das famílias, consumo do governo, investimentos ou exportações. Somado ao valor consumido pelo país estão as importações, por isso, a igualdade entre as três óticas pode ser resumida na Ilustração 8.

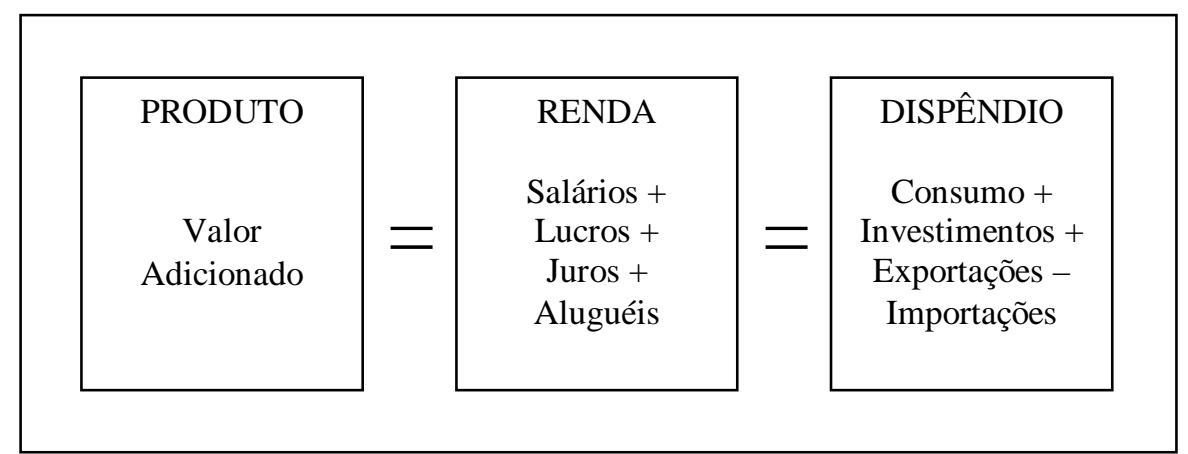

Ilustração 8 - Identidades macroeconômicas: produto, renda e dispêndio FONTE: GREMAUD; TONETO JR. (2007, p. 205) 
[...] o produto interno bruto é igual à soma dos consumos finais de bens e serviços valorados a preço de mercado sendo, também, igual à soma das rendas primárias. Pode, portanto, ser expresso por três óticas: a) do lado da produção - o produto interno bruto é igual ao valor da produção menos o consumo intermediário, mais os impostos, líquidos de subsídios, sobre produtos não incluídos no valor da produção; b) do lado da demanda - o produto interno bruto é igual à despesa de consumo final mais a formação bruta de capital fixo, mais a variação de estoques, mais as exportações de bens e serviços, menos as importações de bens e serviços; c) do lado da renda - o produto interno bruto é igual à remuneração dos empregados mais o total dos impostos, líquidos de subsídios, sobre a produção e a importação, mais o rendimento misto bruto, mais o excedente operacional bruto. (IBGE, 2008b, p. 99).

Na mensuração do produto, outros fatores são considerados. Os bens de capital sofrem desgaste durante o processo produtivo e, portanto, perdem valor. Essa depreciação dos investimentos gera duas possibilidades de mensuração do produto de um país: Produto Interno Bruto e Produto Interno Líquido, de modo que a diferença entre eles é exatamente a depreciação dos bens de capital. Outro fator que gera diferentes possibilidades de cálculo do produto é a tributação indireta, líquida de subsídios, por parte do governo. Os impostos sobre a produção diferenciam o Produto Interno calculado a custos de fatores do Produto Interno calculado a preços de mercado. Por fim, a relação do país com outros países diferencia o conceito de Produto Nacional do conceito de Produto Interno. A diferença entre eles é a renda líquida enviada ao exterior, isto é, "a diferença entre aquilo que é pago por fatores de produção externos utilizados internamente e aquilo que é recebido do exterior por fatores de produção nacionais empregados em outros países" (GREMAUD; TONETO JR., 2007, p. 210).

Gremaud e Toneto Jr. (2007, p. 211-212) alertam que frequentemente comete-se o erro de comparar a dimensão de uma empresa com a de um país, cotejando o faturamento anual da empresa com o PIB do país no mesmo ano. Para fazer tal comparação, deve-se usar aquilo que é adicionado pela empresa aos produtos intermediários utilizados em sua produção. Este valor adicionado da empresa corresponde justamente às rendas que ela gera, salários, lucros, aluguéis etc. A soma destes é compatível com o PIB.

Portanto, para comparar a dimensão de uma empresa com a de um país, deve-se usar o valor adicionado conforme divulgado na DVA. O valor adicionado líquido produzido pela entidade (linha 5 da DVA) corresponde, guardadas as diferenças metodológicas de cálculo, ao Produto Interno Líquido a preços de mercado ( $\left.\mathrm{PIL}_{\mathrm{pm}}\right)$. 
O produto em uma economia é mensurado por um sistema de contas denominado Contabilidade Nacional. A mensuração do PIB brasileiro, realizada pelo IBGE, segue a metodologia internacional sugerida pela Organização das Nações Unidas (ONU), intitulada System of National Accounts 93 (SNA 93). A necessidade de estabelecer comparações entre os diversos países tem feito com que a ONU divulgue, de tempos em tempos, um conjunto de recomendações, que a maior parte dos países procura seguir, a fim de tornar o mais homogêneo possível esse formato (PAULANI; BRAGA, 2007, p. 29). O IBGE publicou, em março de 2007, os resultados da economia conforme nova série do Sistema de Contas Nacionais, tendo como referência inicial o ano 2000 (IBGE, 2008a, p. 12). O Brasil ainda não adota completamente o modelo sugerido no SNA 93, mas os conceitos principais já foram incorporados.

A atividade econômica se traduz por inúmeras transações realizadas por uma infinidade de agentes. A tarefa fundamental do Sistema de Contas Nacionais é classificar essa variedade de agentes, os fluxos econômicos e os estoques de ativos e passivos num número limitado de categorias essenciais, integrando-as num esquema contábil, de forma a obter uma representação do funcionamento da economia. O esquema contábil das contas nacionais tem sua lógica centrada na ideia de reproduzir os fenômenos essenciais da vida econômica de um país: produção de bens e serviços; geração, alocação e distribuição da renda; consumo e acumulação (IBGE, 2008a, p. 17).

O esquema contábil das contas nacionais pode ser representado por meio de uma série de equações:

1. Produto Interno Bruto $(\mathrm{PIB})$ a preços de mercado = valor bruto da produção + impostos, líquidos de subsídios, sobre produtos - consumo intermediário;

2. Produto Interno Bruto (PIB) a preços de mercado $=$ despesa de consumo final + formação bruta de capital fixo + variação de estoques + exportação de bens e serviços - importação de bens e serviços;

3. Renda Nacional Bruta $(\mathrm{RNB})=\mathrm{PIB}+$ ordenados e salários (líquidos, recebidos do exterior) + rendas de propriedade (líquidas, recebidas do exterior);

4. Renda Nacional Disponível Bruta $(\mathrm{RNDB})=\mathrm{RNB}+$ outras transferências correntes (líquidas, recebidas do exterior);

5. Renda nacional disponível bruta $(\mathrm{RNDB})=$ despesa de consumo final + poupança bruta;

6. Poupança bruta + transferências de capital (líquidas, recebidas do exterior) $=$ variações no patrimônio líquido devido à poupança e à transferência de capital;

7. Poupança bruta + transferências de capital (líquidas, recebidas do exterior) $=$ formação bruta de capital fixo + variação de estoques + aquisições líquidas de cessões de ativos não-financeiros nãoproduzidos + capacidade/necessidade líquida de financiamento; e

8. Capacidade/necessidade líquida de financiamento = Exportação de bens e serviços - importação de bens e serviços + ordenados e salários (líquidos, recebidos do exterior) + rendas de propriedade (líquidas, recebidas do exterior) + outras transferências correntes (líquidas, recebidas do exterior) 
+ transferências de capital (líquidas, recebidas do exterior) - aquisições líquidas de cessões de ativos não-financeiros não-produzidos. (IBGE, 2008a, p. 19).

O Sistema de Contas Nacionais está centrado em dois grupos de informações: as Contas Econômicas Integradas (CEI), um conjunto de contas de operações e contas de ativos e passivos dos setores institucionais e do resto do mundo, e a Tabela de Recursos e Usos (TRU), matriz que traz os resultados agregados macroeconômicos por setores de atividade econômica. A integração entre os grupos (CEI e TRU) garante que os saldos obtidos pela classificação de setores institucionais, nas CEI, sejam idênticos aos obtidos pela classificação de atividades na TRU (FEIJÓ et al., 2003, p. 51).

\footnotetext{
Em cada linha da tabela das CEI são registradas as operações, saldos e agregados macroeconômicos, cuja seqüência permite identificar o conjunto de equações que retratam o funcionamento da economia nacional, desde a etapa da geração da renda, passando pela sua apropriação e distribuição, alcançando a etapa da utilização da renda nacional, quando se estima o consumo e a poupança da economia. Em seguida, as equações das CEI registram os fluxos relativos à acumulação de capital da economia, os quais permitem identificar a capacidade, ou necessidade de financiamento da economia. (IBGE, 2008b, p. 22).
}

O Quadro 16 traz a estrutura das CEI, exibindo a conta de produção. A tabela das CEI de 2006 está exposta no Anexo F. As Contas Econômicas Integradas dividem-se em contas correntes (produção e renda) e contas de acumulação. A conta de produção mostra o resultado do processo de produção: valor bruto de produção, consumo intermediário e valor adicionado (PIB). A conta de renda se divide em distribuição primária da renda, distribuição secundária da renda e uso da renda. As rendas primárias são rendas recebidas pelas unidades institucionais por sua participação no processo produtivo ou pela posse de ativos necessários à produção. A distribuição secundária da renda mostra a passagem do saldo da renda primária de um setor institucional para renda disponível, após o recebimento e pagamento de transferências correntes (exceto as transferências sociais em espécie). A conta de uso da renda disponível tem como objetivo mostrar como as famílias, as instituições sem fins de lucro a serviço das famílias e as administrações públicas alocam sua renda disponível em consumo e poupança. A poupança, saldo final das operações correntes, é o ponto de partida das contas de acumulação. A conta de capital, primeira deste conjunto, registra as operações relativas às aquisições de ativos não financeiros. As contas de transferências de capital, também deste conjunto, implicam em redistribuição de riqueza. Por fim, o saldo das contas é a capacidade/necessidade líquida de financiamento em cada setor institucional (IBGE, 2008a, p. 21-25). 
Quadro 16 - Estrutura parcial das Contas Econômicas Integradas

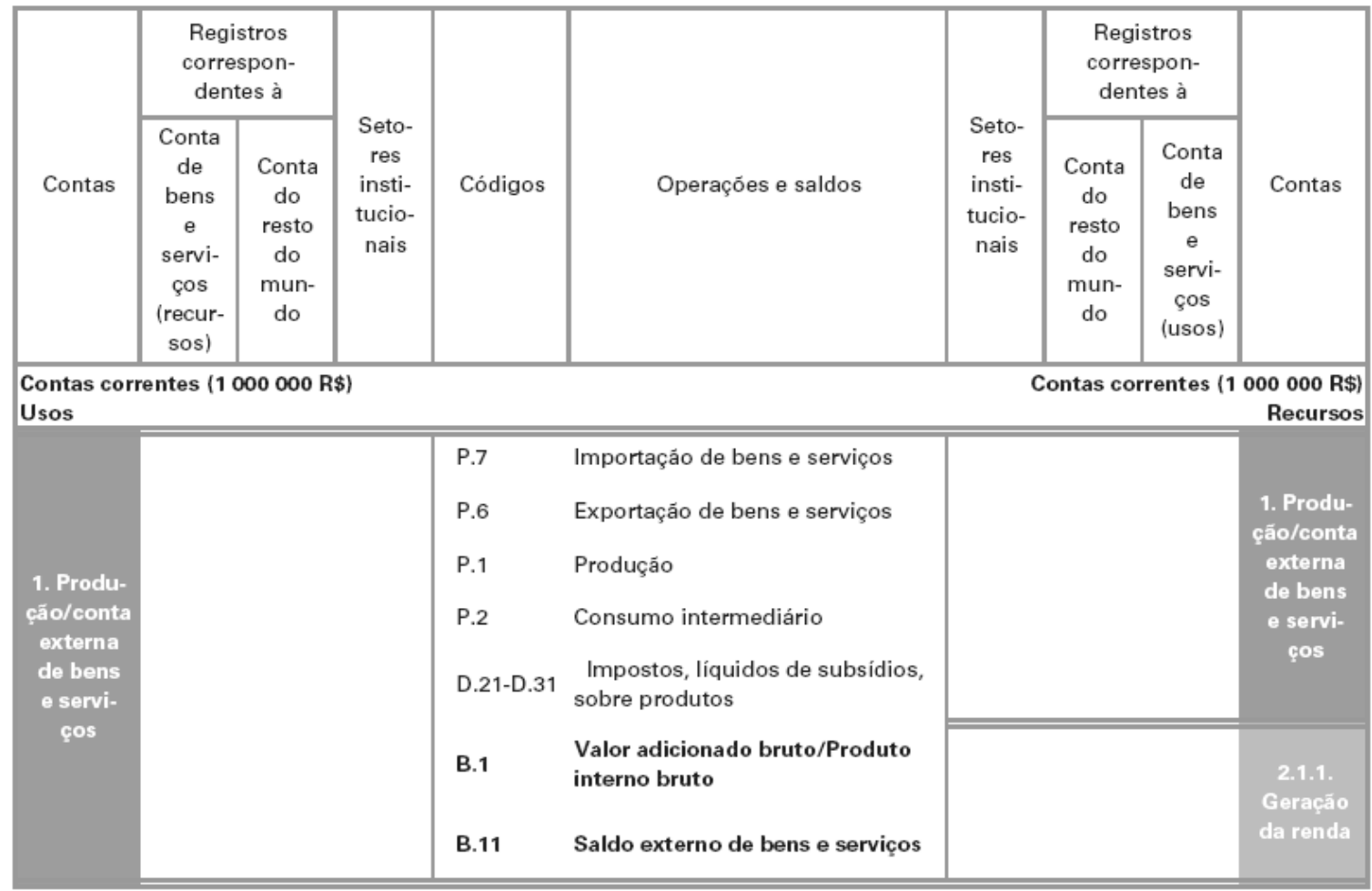

FONTE: IBGE (2008a, p. 21)

O Quadro 16 mostra que nas linhas da tabela-síntese das CEI figuram as operações, saldos e alguns agregados, descritos na coluna central. Nas colunas à esquerda do corpo central, são registrados os usos, operações que reduzem o valor de um setor institucional, e nas colunas à direita são registrados os recursos, operações que aumentam o valor de um setor institucional.

As unidades institucionais são unidades econômicas capazes de possuir ativos e contrair passivos por sua própria conta, caracterizadas por autonomia de decisão e unidade patrimonial. [...] As unidades institucionais são grupadas para formar os setores institucionais, segundo similaridades em suas funções, comportamento e objetivos principais. Assim, são definidos os seguintes setores: - S.11 - empresas não-financeiras: unidades institucionais cujo objetivo é a produção de bens e serviços mercantis não-financeiros;

- S.12 - empresas financeiras: unidades institucionais que se dedicam, principalmente, à intermediação financeira ou às atividades financeiras auxiliares;

- S.13 - administrações públicas: unidades institucionais que, além de cumprirem suas responsabilidades políticas e seu papel de reguladores da economia, produzem bens e serviços não-mercantis e redistribuem renda e riqueza;

- S.14 - famílias: conjunto das pessoas físicas da economia, sendo suas principais funções a oferta de mão-de-obra e o consumo e, enquanto empresários, produzir bens e serviços mercantis; e

- S.15 - instituições sem fins de lucro a serviço das famílias: entidades jurídicas ou sociais criadas com o fim de produzir bens ou serviços para as famílias, cujo estatuto não lhes permite ser uma fonte de rendimento, lucro ou outro ganho financeiro para as unidades que as criam, controlam ou financiam. (IBGE, 2008a, p. 31-32) 
A lógica de recursos e usos também é evidenciada na TRU, mas com a ótica de atividades e não de setores institucionais. O principal objetivo da TRU é a análise dos fluxos de bens e serviços e dos aspectos básicos do processo de produção. Ela mostra a estrutura de insumos e estrutura de produção de produtos por atividade (IBGE, 2008a, p. 27). A TRU apresenta seis blocos de informações, os quadrantes:

- $\mathrm{A}=$ oferta,

- $\mathrm{A}_{1}=$ produção,

- $\mathrm{A}_{2}=$ importação,

- $\mathrm{B}_{1}=$ consumo intermediário,

- $\mathrm{B}_{2}=$ demanda final e

- $\mathrm{C}=$ decomposição do valor adicionado em categoria de renda.

As equações básicas da economia mostram a relação entre os quadrantes e facilitam a compreensão da TRU, exposta no Anexo G. São elas:

- Oferta $=$ Produção + Importação $\Rightarrow A=A_{1}+A_{2}$ (equação representa os recursos postos à disposição no país);

- Oferta $=$ Consumo Intermediário + Demanda final $\Rightarrow \mathrm{A}=\mathrm{B}_{1}+\mathrm{B}_{2}$ (equação representa os possíveis usos dos recursos postos à disposição e $\mathrm{B}_{1}$ e $\mathrm{B}_{2}$ formam matriz insumoproduto);

- $\mathrm{PIB}=$ Demanda final - Importação $=\mathrm{B}_{2}-\mathrm{A}_{2} \mathrm{e}$

- $\mathrm{PIB}=$ Produção - Consumo Intermediário $=\mathrm{A}_{1}-\mathrm{B}_{1}$.

As matrizes $\mathrm{A}, \mathrm{A}_{2}, \mathrm{~B}_{2}$ e $\mathrm{C}$ são interpretadas pelo cruzamento dos títulos de suas linhas e colunas. Já as matrizes $A_{1}$ e $B_{1}$ podem gerar dúvidas ao leitor na interpretação por cruzar setores econômicos com os mesmos setores econômicos. A matriz $\mathrm{A}_{1}$ cruza informações de oferta e é composta por elementos $\mathrm{x}_{\mathrm{ij}}$ que representam a oferta de produtos característicos do setor i que foram produzidos pelo setor $\mathrm{j}$. Se os setores econômicos fossem puros, isto é, produzissem apenas os bens relativos às atividades que os caracterizam, a matriz $\mathrm{A}_{1}$ seria uma matriz identidade ${ }^{17}$. A matriz B1 apresenta informações do consumo intermediário das atividades e é composta por elementos $\mathrm{x}_{\mathrm{ij}}$ que representam os produtos transferidos pelo setor i para consumo no setor j (NUNES, 1998, p. 148-151).

\footnotetext{
${ }^{17}$ A matriz identidade possui número de linhas igual ao número de colunas e caracteriza-se por apresentar os elementos $\mathrm{x}_{\mathrm{ij}}$ iguais a 1 quando i é igual a j e iguais a 0 quando i é diferente de $\mathrm{j}$.
} 
O Anexo G mostra a TRU condensada em 12 setores. Entretanto, as TRUs anuais da série do Sistema de Contas Nacionais são constituídas de 149 atividades e 293 produtos sendo que, para divulgação, são posteriormente agregadas para 55 atividades e 110 produtos. As atividades foram definidas por uma agregação da Classificação Nacional de Atividades Econômicas (CNAE) utilizada pelas pesquisas econômicas do IBGE e pelos principais registros administrativos do país. A classificação por grupos de produtos é derivada diretamente da classificação de atividades e procura manter a homogeneidade de cada grupamento no que diz respeito à origem - atividade produtora e procedência, nacional ou importada - e ao destino - tipo de consumidor e/ou usos específicos (IBGE, 2008a, p. 46).

Retomando a questão dos investimentos socioambientais, o objetivo aqui é entender como tais investimentos estão contabilizados no Sistema de Contas Nacionais. Da maneira como são contabilizados na DVA atualmente, os investimentos socioambientais deveriam aparecer como consumo intermediário tanto na TRU quanto na conta de produção (CEI). Entretanto, observou-se que isso não acontece.

Inicialmente, é necessário observar as fontes de coleta de dados para construção das contas nacionais. O IBGE utiliza, principalmente, dados obtidos por pesquisas realizadas pelo próprio instituto (Pesquisa Industrial Anual - PIA, Pesquisa Anual da Indústria da Construção - PAIC, Pesquisa Anual do Comércio - PAC e Pesquisa Anual de Serviços - PAS) e dados informados na Declaração de Informações Econômico-fiscais da Pessoa Jurídica (DIPJ). Os questionários do IBGE, assim como a DIPJ, são preenchidos pela própria empresa e não possuem campo específico para informar as doações ou transferências realizadas no ano. Elas são informadas como “outras despesas operacionais” ou nem são informadas. As informações de doações só podem ser obtidas pelo IBGE por meio da declaração do imposto de renda das entidades sem fins de lucro e das pessoas físicas, informações também usadas na elaboração das contas nacionais.

Para análise dos investimentos socioambientais levantados no capítulo anterior, será usada ordem inversa ao que foi apresentado. Inicialmente, será discutida a questão dos meios de transferências de recursos. O Quadro 17 retoma a tipologia quanto a esse quesito. As transferências podem ocorrer direto para a pessoa física, para pessoa jurídica sem fins de 
lucro, para pessoa jurídica com fins de lucro ou para o governo. Podem ser doações ou pagamentos por serviços adquiridos. E ainda podem ou não ter recebido incentivo físcal.

Quadro 17 - Tipologia Final dos Meios de Transferência de Recursos nos Investimentos Socioambientais
\begin{tabular}{|c|lc|}
\hline \multicolumn{4}{|c|}{ parte C - Caracterização da transferência de recursos pela empresa } \\
\hline \hline \multirow{3}{*}{ Meio Ambiente } & i. & ocorre doação direta para pessoas físicas \\
\hline & ii. & ocorre doação para uma pessoa jurídica sem fins lucrativos \\
\cline { 2 - 3 } & iii. & ocorre pagamento para uma pessoa jurídica sem fins lucrativos por produto ou serviço adquirido \\
\cline { 2 - 3 } & iv. & ocorre pagamento para uma pessoa jurídica com fins lucrativos por produto ou serviço adquirido \\
\hline \hline \multirow{4}{*}{ Comunidade } & v. & ocorre doação para programas de governo \\
\hline & i. & ocorre doação direta para pessoas físicas \\
\hline & ii. & ocorre doação para uma pessoa jurídica sem fins lucrativos em troca de incentivo fiscal \\
\hline & iii. & ocorre doação para uma pessoa jurídica sem fins lucrativos sem se beneficiar de incentivos fiscais \\
\hline & iv. & ocorre pagamento para uma pessoa jurídica sem fins lucrativos por produto ou serviço adquirido \\
\hline & v. & ocorre pagamento para uma pessoa jurídica com fins lucrativos por produto ou serviço adquirido \\
\hline & vi. & ocorre doação para programas do governo \\
\hline
\end{tabular}

Conforme análise central deste estudo, para participar do valor adicionado como formação, os investimentos socioambientais devem se caracterizar como consumo intermediário - "bens e serviços utilizados como insumos (matérias-primas) no processo de produção" (IBGE, 2008a, p. 164). Caso contrário, serão caracterizados como distribuição do valor adicionado. Assim, os casos de doação sempre serão distribuição de valor adicionado porque não representam insumos do processo de produção. O pagamento por serviço adquirido poderá compor a formação de valor adicionado se o serviço for relacionado ao processo produtivo, pois será consumo intermediário. Se uma empresa compra presentes de natal para distribuir na comunidade vizinha, estará distribuindo valor adicionado, pois os presentes não possuem relação com a produção.

A diferenciação entre transferência para pessoa física, pessoa jurídica com ou sem fins lucrativos e programas de governo influenciará apenas na distribuição do valor entre os setores institucionais nas CEI. Se uma empresa faz uma doação para uma instituição sem fins de lucro, ela deveria aparecer na linha de transferências correntes diversas que pertence à conta nacional de distribuição secundária da renda, e na coluna de usos do setor institucional das instituições sem fins de lucro a serviço da família. Se a doação for para o governo, aparece na mesma linha, mas na coluna de usos da administração pública. E se for para pessoa física, aparece na coluna de usos da família, mas na mesma linha. 
Por fim, o fato de haver aproveitamento do incentivo fiscal não muda a classificação do investimento socioambiental em distribuição de valor adicionado, conforme já discutido. Investimentos sociais que fomentem o esporte, a cultura, os direitos das crianças e adolescentes e atividades audiovisuais podem ser deduzidos do imposto de renda a pagar até o limite fixado pelo Regulamento do Imposto de Renda. Nesse caso, haverá alocação primária da renda para excedente operacional bruto, depois distribuição secundária para impostos correntes sobre a renda e depois transferências correntes diversas para as instituições sem fins de lucros a serviço das famílias. Ou seja, as mudanças ocorrem após a apuração do valor adicionado, por isso não muda a adequação como distribuição de valor adicionado.

Com relação à categoria Meio Ambiente, não há contabilização de questões ambientais na metodologia de contas nacionais da ONU, SNA 93, nem nas contas nacionais brasileiras. É uma matéria em estudo (STIGLITZ; SEN; FITOUSSI, 2009), mas atualmente, não há contabilização. Apenas as atividades formalizadas (com código na Classificação Nacional de Atividades Econômicas - CNAE) aparecem nas contas nacionais pelo modelo em vigor. Alguns exemplos: reflorestamento, produção e consumo de energia e reciclagem.

As atividades de Meio Ambiente vinculadas ao processo produtivo da empresa aparecem nas contas nacionais como consumo intermediário, pois as empresas informam o consumo por meio dos questionários da PIA, PAC ou PAS. Conforme analisado no tópico anterior, os gastos que já compõem o processo produtivo, independente de estarem relacionados com Meio Ambiente, não seriam considerados investimentos ambientais porque não envolvem dispêndio de recursos adicionalmente aos já inerentes à produção.

As atividades de Meio Ambiente não vinculadas ao processo produtivo podem nem aparecer nas contas nacionais. Se a empresa realiza um projeto de educação e treinamento em temas de meio ambiente (para a comunidade, não para seus empregados), ela deverá informar ao IBGE como uma produção, com código do CNAE e volume de produção. Caso contrário, o IBGE não tomará conhecimento do projeto, e isso não aparecerá na produção do país. Não obstante, se o projeto for financiado pela empresa por meio de doação para entidades sem fins de lucro e esta informar a fonte de recursos e sua aplicação na Declaração do Imposto de Renda, haverá reconhecimento nas contas nacionais como uma produção da entidade. Para a empresa, o investimento caracterizar-se-á como doação, portanto, transferência secundária da renda. 
Quando ocorre investimento em ativos ambientais, a empresa informa a aquisição de bens de capital por meio dos questionários. Nas Contas Econômicas Integradas, ocorre lançamento desse valor como formação de capital fixo, derivado da conta de poupança que é uma forma de uso da renda. Portanto, tais investimentos seriam considerados distribuição de valor adicionado. Entretanto, a aquisição desses bens aparece na DVA apenas pela conta de depreciação à medida que ocorre o desgaste do bem, o que não corresponde ao que é reconhecido nas contas nacionais porque a depreciação não é contabilizada nas CEI.

Quanto à comunidade, os investimentos sociais caracterizados por doações já foram discutidos. Devem ser avaliados os casos de patrocínios e de campanhas de arrecadação. O caso dos patrocínios nas contas nacionais é bem definido porque as atividades econômicas estão definidas conforme a classificação CNAE. Esportes ou artes não se caracterizam como atividades de propaganda, pois apesar de estarem veiculando a marca da empresa, não se enquadram nessa atividade. Assim, os patrocínios, para a Contabilidade Nacional, são transferências de renda e não se caracterizam como consumo intermediário.

Itens de consumo, como, por exemplo, energia elétrica, combustível, fretes e carretos pagos a terceiros, aluguéis e despesas com propaganda e publicidade podem ser diretamente associados a produtos. [...] Optou-se por atribuir a uma única atividade (serviços prestados às empresas, onde estão classificados os estabelecimentos de empresas de publicidade) o consumo total dos veículos de publicidade e propaganda, tais como anúncios na imprensa, televisão e rádio e impressos de propaganda. O produto publicidade e propaganda refere-se, portanto, ao total dos serviços das agências e dos veiculadores de publicidade, correspondendo, pela ótica do consumo, às despesas com publicidade e propaganda alocadas às diversas atividades. (IBGE, 2008a, p. 63-64).

O caso das campanhas de arrecadação também fica mais simples, na ótica das contas nacionais. Isso porque origem e aplicação de recursos são bem definidas, mesmo que haja diversas transferências até a doação chegar ao beneficiário. Assim, o que ocorre é transferência, geralmente, das famílias para as famílias. Se os recursos forem contabilizados em uma entidade sem fins lucrativos antes de serem direcionados para as famílias, haverá transferência das famílias para a entidade e depois da entidade para as famílias. Se uma empresa também contabilizar a passagem do recurso (e esse não se configurar consumo intermediário da empresa), haverá mais uma transferência. A arrecadação não entra como produção das instituições sem fins de lucro porque arrecadar donativos não é uma atividade nas contas nacionais. 


\subsubsection{Validação dos resultados: a visão do IBGE}

Para validar a análise do problema sob a ótica do IBGE, foi realizada entrevista semiestruturada com Dr. Roberto Luís Olinto Ramos, doutor em Engenharia de Produção e chefe da Coordenação de Contas Nacionais do IBGE. O roteiro de entrevista está no Apêndice 5 deste trabalho.

Após a apresentação desta pesquisa, o Sr. Olinto fez questão de esclarecer que as contas nacionais medem a produção do país por suas atividades econômicas e remuneração dos fatores de produção e que não existe a pretensão de medir bem-estar. "Bem-estar é outro indicador econômico". A análise da entrevista está separada nas categorias Meio Ambiente e Comunidade.

Quanto ao meio ambiente, Sr. Olinto afirmou que o sistema de contas nacionais mostra operações econômicas bem definidas, e a tentativa de incluir o consumo do meio ambiente a essas operações é recente, apesar de estar pesquisando isso, ele ainda não tem conhecimento de resultados satisfatórios em nenhum país do mundo. Foram citados alguns exemplos. Os Estados Unidos tentam criar uma conta de meio ambiente no sistema de contas nacionais há treze anos, mas ainda não o fizeram. A Austrália tem uma conta nacional que mensura a produção e consumo de água no país. A Inglaterra tem uma conta de meio ambiente nas contas nacionais que mostra um conjunto de tabelas sobre o uso de recursos ambientais: extração e consumo de petróleo e gás, consumo de energia, emissão de $\mathrm{CO}_{2}$, extração de biomassa entre outras.

Segundo Sr. Olinto, o problema desses exemplos é a falta de integração dessas contas com a contabilidade nacional. Ele ressaltou que o Brasil tem condições de reunir um conjunto de informações semelhantes, pois apenas os dados levantados pela Petrobras já forneceriam várias tabelas como as mostradas na conta inglesa. Entretanto, não haveria grande mudança em relação ao que já existe, porque o IBGE não estaria medindo o impacto do consumo do meio ambiente na produção. Para mensurar meio ambiente com os agregados econômicos, o esforço deve ser na direção de fazer as contas nacionais refletirem esses resultados apresentados em tais tabelas. 
Sobre o estudo de Stiglitz, Sen e Fitoussi (2009), ele acredita que o estudo seja louvável (o relatório final foi divulgado no dia anterior à entrevista, portanto ele ainda não havia lido), mas prevê as dificuldades de aplicação dos resultados no mundo, pois muitos países não têm estrutura para levantar as informações necessárias para melhorar seus sistemas de contas nacionais. Levantar informações estatísticas tem custo alto e é necessário um longo período de coleta e análise dos dados antes da implantação de mudanças. Além disso, certas variáveis não são mensuráveis. Segundo ele, o Sistema de Contas Nacionais dos EUA tem cerca de 300 pessoas e ainda não implantaram uma conta de meio ambiente. A área de contas nacionais do Brasil tem cerca de 20 pessoas.

O Brasil tem caminhado para incluir nas contas nacionais a produção e consumo de água e florestas. A intenção inicial é incluir geração e consumo de recursos naturais para depois tentar integrar as variações de estoques (degradação). Sr. Olinto acredita que seja mais importante, neste momento, ter uma medida mais precisa do patrimônio econômico do país, antes de testar métricas para mensuração do patrimônio ambiental. Segundo ele, o Brasil ainda não consegue mensurar com precisão o patrimônio de construções ou de máquinas e equipamentos que são ativos tangíveis. Então, “isso tudo é um plano de médio prazo".

Sr. Olinto lembrou que a CNAE 2.0 já tem muitos serviços ambientais mensurados como atividades econômicas, entre eles: reflorestamento, reciclagem, tratamento de resíduos. E afirmou que a atividade formal econômica é "fácil de medir economicamente, o problema é medir o impacto econômico disso no meio ambiente - qual é a medida econômica de redução de $\mathrm{CO}_{2}$ ?" Esses estudos ainda são embrionários em todo o mundo.

Quanto à Comunidade, o entrevistado afirmou que as doações empresariais são redistribuições do Excedente Operacional Bruto. Segundo ele, a remuneração do empresário está dentro do excedente operacional, mas este agregado não inclui apenas a remuneração do executivo, e o detalhamento disso vai acontecer nas contas de renda.

Segundo Sr. Olinto, quando ocorre a doação direta para uma família em bens, haverá consumo da família e ainda uma transferência de renda para justificar o consumo. Por exemplo, quando ocorre a doação por uma siderúrgica de cestas básicas para a comunidade, nas contas nacionais haverá produção de alimentos, transferência de dinheiro fíctícia entre empresas não financeiras e famílias e consumo das famílias. 
Se a empresa criar uma ONG para prestar os serviços sociais, haverá uma instituição sem fins de lucros (ISFL) a serviço das famílias prestando um serviço não mercantil. Essa atividade já é mensurada nas contas nacionais, e as informações são obtidas pela DIPJ das instituições. Nas contas nacionais, o valor de produção de uma instituição sem fins de lucro é seu próprio custo de produção, obtido pela soma da remuneração de pessoal e do consumo intermediário, conforme explicou o entrevistado.

Sr. Olinto corrobora que sempre que uma empresa fizer uma doação de produtos, ela estará transferindo recursos de uma indústria de quem ela comprou para o consumo das famílias. Quando a doação ocorre por meio de uma ISFL, o impacto nas contas nacionais é o mesmo, só aumenta o volume de lançamentos de transferência. Novamente haverá produção de alimentos e consumo das famílias. Nesse caso, existe ainda uma transferência da empresa para ISFL e um serviço da ISFL para as famílias.

Sobre os trabalhos voluntários realizados em projetos sociais por empregados da companhia, Sr. Olinto disse que quando uma pessoa registrada na empresa é alocada para executar um projeto social, a empresa deveria declarar a atividade real exercida pelo empregado, como uma produção secundária não mercantil. Porquanto, quando a empresa doa estoque, imobilizado ou dinheiro, o efeito no PIB será o mesmo, e as operações nas contas nacionais poderão aumentar em volume de transferência entre a produção e o consumo.

Sr. Olinto reforça que as contas sempre devem registrar a origem do recurso e o destino da produção. A forma de financiamento desse destino pode aparecer de várias formas diferentes. Entretanto, a empresa não tem como informar as doações e as transferências realizadas para o IBGE, corroborando as informações obtidas em análise dos formulários. Segundo o entrevistado, o IBGE deveria incluir esse campo nos formulários.

Em caso de atividade econômica lucrativa desenvolvida pela ISFL para financiar a atividade não mercantil, a entidade deve registrar a atividade econômica mercantil desenvolvida com suas receitas e custos separados na DIPJ. Nas contas nacionais, haverá registro da atividade econômica prestada pelo setor de serviços não mercantis. 
Pesquisadora: o senhor concorda que sempre que uma empresa está fazendo doação, ela está transferindo renda entre os fatores de produção?

Sr. Olinto: exato.

Pesquisadora: isso não participa do consumo intermediário dela?

Sr. Olinto: não, o que é que vai mudar... ela não afeta o PIB, ela muda a renda disponível por setor institucional. Quando uma família recebe uma doação, a renda disponível dela está aumentando.

Sr. Olinto ressaltou a diferença entre o PIB e a renda disponível para a economia nacional: juros e dividendos recebidos do resto do mundo e transferências para o resto do mundo. Ao abrir as informações por setor, a lógica é a mesma. Quando uma empresa faz uma doação para uma ISFL, ela aumenta a renda disponível dessa entidade. E o uso da renda disponível será consumo e/ou investimentos. Com isso é possível observar a redistribuição interna. "As doações e outras transferências são redistribuições da renda dentro dos setores".

Após estudar os investimentos socioambientais e a remuneração dos fatores de produção sob a ótica conceitual e sob a ótica do IBGE, a análise deste capítulo pode ser concluída. Na DVA, a distribuição de valor adicionado mostra a remuneração dos fatores de produção e a alocação de renda para o governo. Apesar de algumas diferenças na metodologia de cálculo, o valor adicionado apresentado na DVA baseia-se nos mesmos conceitos do produto nacional. A inclusão dos investimentos socioambientais entre as remunerações de fatores da DVA não eliminará a base conceitual por trás da demonstração. Ao contrário, essa categoria de gastos, que vem aumentando sua participação nas empresas, fica mais adequada como distribuição de valor adicionado quando observadas algumas condições:

- deve haver dispêndio por parte da empresa investidora, além daqueles gastos gerados pelo próprio processo produtivo, ou, pelo menos, o valor deve ter sido registrado na contabilidade da companhia;

- deve haver benefício para a comunidade, além dos benefícios proporcionados pela simples existência da empresa;

- o consumo final do bem ou serviço, objeto de investimento social, deve ocorrer na comunidade;

- o dispêndio não pode representar compensação de externalidades negativas geradas pelo processo produtivo;

- o dispêndio não pode representar consumo de bens ou serviços usados no processo produtivo;

- quando o investimento for fruto de incentivo fiscal, a distribuição de valor adicionado deverá ser registrada como benefício para o governo, não para a comunidade. 


\section{CONCLUSÕES E CONSIDERAÇÕES FINAIS}

A Demonstração do Valor Adicionado tornou-se obrigatória para as companhias de capital aberto que atuam no mercado brasileiro a partir de 2008. É uma demonstração de cunho econômico-social e traz informações antes não divulgadas, como o valor total gasto com empregados e o valor total de tributos imputados à empresa segregados por esfera de governo. Seu objetivo é mostrar a riqueza adicionada pela empresa à economia do país e a estrutura de remuneração dos fatores de produção adotada pela companhia.

Não é uma demonstração inserida nas normas internacionais de contabilidade, emitidas pelo IASB, e tem pouca adoção em outros países. Entretanto, as informações da DVA compõem um dos indicadores do modelo GRI de Balanço Social. Apesar de algumas diferenças entre a estrutura da DVA adotada no Brasil e a estrutura proposta para o indicador intitulado EC1 pelo GRI, as informações solicitadas são basicamente as mesmas, com exceção do valor dos investimentos realizados na comunidade, solicitado no modelo de Balanço Social. Esse modelo tem levado algumas empresas a divulgarem suas DVAs inserindo uma linha com os investimentos sociais dentre as linhas de distribuição de valor adicionado.

Nesse contexto, esta tese buscou investigar, à luz dos conceitos econômicos, quais as condições para os investimentos socioambientais serem considerados distribuição de valor adicionado na DVA. Para responder às questões de pesquisa, foram realizadas pesquisa teórica, sobre responsabilidade social e sobre Demonstração do Valor Adicionado, e pesquisa empírica com os Relatórios de Sustentabilidade de 22 companhias abertas no Brasil. Por fim, os investimentos socioambientais identificados na pesquisa empírica foram analisados sob a ótica dos conceitos econômicos relacionados a valor adicionado e sob a ótica do IBGE, responsável pelo cálculo do produto nacional no país.

Os conceitos de responsabilidade social discutidos estão divididos em quatro grupos teóricos diferentes. O primeiro traz a visão da economia liberal com a ideia de que não é correto imputar às empresas a responsabilidade de pensar no bem comum, já que o objetivo dessas é defender os ganhos de seus acionistas em uma competição justa, sem enganos nem fraudes. $\mathrm{O}$ 
segundo grupo discute a questão do poder social da empresa, isto é, a empresa deve assumir responsabilidades à proporção do poder social conquistado. O terceiro grupo é caracterizado pelo reconhecimento por parte da empresa das demandas sociais que a cercam. Muitas vezes, a adoção das práticas de RSC se dá pela pressão do ambiente (clientes, concorrentes, funcionários entre outros) e não pela conscientização do seu papel na sociedade, ou seja, a empresa investe em ações sociais como forma de legitimação. Por fim, o quarto grupo coloca a responsabilidade social da empresa como a necessidade de se preocupar com impactos socioambientais da corporação na sociedade.

Duas correntes depreendem-se dessas teorias: a empresa decide realizar investimentos sociais para melhorar sua imagem; o administrador realiza investimentos sociais para atender a seus valores morais e éticos. Seja qual for o caminho adotado, a empresa acaba usando suas ações sociais para melhorar sua imagem. Então, a empresa pode realizar a ação social sem pensar no marketing para a empresa, mas depois usá-la para incrementar sua imagem. Ou pode tomar a decisão de agir socialmente, já pensando em uma estratégia de imagem da organização.

A pesquisa empírica realizada evidencia a necessidade da empresa de se relacionar bem com seus stakeholders. As informações analisadas mostraram como a empresa tenta melhorar sua relação com a comunidade, especialmente vizinhança da companhia, com empregados, meio ambiente, fornecedores e investidores. Vale ressaltar a incompletude das informações: falta de clareza sobre o envolvimento da empresa nos projetos divulgados, falta de dados sobre o investimento realizado, divulgação de projetos que já não recebem mais recursos da companhia, falta de informações sobre parcerias efetivadas para realização dos projetos, entre outras.

As informações divulgadas nos relatórios analisados foram categorizadas quanto ao beneficiário divulgado na informação, quanto ao dispêndio da empresa e quanto ao meio de transferência. As informações foram tipificadas em quatro categorias: Empregados, Meio Ambiente, Comunidade e Perfil Organizacional, com diversas subcategorias de atividades. A categoria Perfil Organizacional não foi analisada por não se caracterizar como informação socioambiental. A categoria Empregados não foi analisada por ter sua posição na DVA bem definida como distribuição de valor adicionado. Este estudo focou suas análises nas categorias Meio Ambiente e Comunidade e observou o envolvimento de muitas ações realizadas com o processo produtivo da empresa. 
Quanto ao dispêndio, a análise dos relatórios mostrou que diversas informações divulgadas diziam respeito a valores éticos ou políticas, sem dispêndio para a empresa. Então, inicialmente, observou-se a necessidade de identificar o sacrifício de ativos realizado pela empresa para caracterizar a existência de investimento socioambiental. Posteriormente, identificou-se a necessidade de tais gastos serem adicionais ao processo produtivo da empresa, isto é, não serem fundamentais para tal processo, pois nos relatórios, decisões de investimentos operacionais foram divulgadas como ações socioambientais.

Por fim, a necessidade de observar o meio de entrega dos recursos ficou evidente. As empresas podem realizar doações ou pagamento por bens ou serviços adquiridos. Podem entregar os recursos para pessoa física, pessoa jurídica com fins de lucro ou pessoa jurídica sem fins de lucro. E, ainda, podem se beneficiar ou não de incentivos fiscais.

Valor adicionado é a riqueza acrescentada a uma economia em um período de tempo. É o valor acrescentado ao custo de insumos adquiridos para remunerar os fatores de produção, capital, terra e trabalho. A remuneração dos fatores pode ser transferida a outro, como o governo, e haverá redistribuição da renda gerada. Dessa forma, os investimentos socioambientais poderiam, inicialmente, ser classificados como insumos do processo produtivo, como remuneração dos fatores de produção ou como distribuição secundária da renda.

Os investimentos socioambientais caracterizados como doações não podem ser considerados insumos do processo produtivo porque não há recebimento de produto ou serviço em contrapartida do recurso. Também não podem ser considerados como remuneração dos fatores de produção porque não se configura aluguel do serviço do capital, terra ou trabalho. Portanto, as doações deveriam ser classificadas como redistribuição da renda gerada e, como governo, aparecer na DVA em distribuição do valor adicionado.

Contudo, é importante observar a questão das externalidades negativas. Quando a empresa realiza investimentos na tentativa de compensar prejuízos previamente causados à sociedade, entende-se que há redução do valor adicionado, pois a empresa estará "pagando" por insumo utilizado no processo produtivo, seja um recurso natural, um bem público ou prejuízos causados a stakeholders. 
Já para os investimentos socioambientais caracterizados como pagamento por produto ou serviço adquirido, deve-se observar o beneficiário final do produto ou serviço. Quando o beneficiário final for a comunidade ou o meio ambiente, sem contrapartidas destes, configurase redistribuição da renda ou distribuição do valor adicionado.

Se houver aproveitamento de incentivo fiscal no investimento social, haverá distribuição de valor na DVA, mas no grupo de impostos, taxas e contribuições, não como investimentos socioambientais. Esse investimento é um redirecionamento do imposto devido, e, se não houvesse o investimento social, deveria haver o pagamento do imposto. Se esses investimentos não forem classificados nesse grupo - governo, poderá haver distorção no cálculo da carga tributária da empresa, uma das utilidades da DVA.

Com isso, propõe-se a inclusão de uma linha na DVA para os investimentos socioambientais que atendam às seguintes condições:

- haver dispêndio por parte da empresa investidora além daqueles gerados pelo próprio processo produtivo, ou, pelo menos, o valor deve ter sido registrado na contabilidade da companhia;

- haver benefício para a comunidade além daqueles proporcionados pela simples existência da empresa;

- o consumo final do bem ou serviço, objeto de investimento social, ocorrer na comunidade;

- o dispêndio não representar compensação de externalidades negativas geradas pelo processo produtivo;

- o dispêndio não representar consumo de bens ou serviços usados no processo produtivo; e

- não haver aproveitamento de incentivo fiscal caracterizado como dedução do tributo devido.

Mudar a estrutura de uma demonstração contábil envolve muita discussão e muitas simulações para análise dos impactos da mudança. Esta tese dá início à discussão de incluir na DVA uma linha para os investimentos socioambientais. 
Uma questão que se levanta para discussão posterior é o impacto da mudança na decisão de investimento das empresas. Conforme já ressaltado, mesmo que a empresa almeje um benefício próprio quando realiza um investimento socioambiental, a sociedade também pode ganhar com isso. Beneficiar a empresa não inviabiliza a ação social. É importante que a mudança na demonstração não desestimule a realização de projetos sociais bem-sucedidos. Pode haver projetos com investimento baixo e grande impacto social ou o contrário. Por outro lado, é necessário incentivar a divulgação dos valores investidos nos projetos. Alguns relatórios analisados, no estudo empírico, não evidenciaram o valor e a forma de investimento em nenhum projeto social ou ambiental divulgado.

Se houver a alteração da estrutura da DVA proposta, as empresas deveriam evidenciar em notas explicativas quais projetos foram incluídos nesse novo item, a forma de realização do investimento, especialmente, quais os ativos entregues, e, ainda, quais as parcerias envolvidas. Assim, a sociedade poderia julgar as decisões da empresa e agir como "reguladora" do mercado.

Devem-se destacar algumas limitações na elaboração deste trabalho. Uma delas decorre do conceito de responsabilidade social ainda estar em constante mudança. A tipologia criada limita-se às práticas socioambientais atuais das empresas. Com a evolução do conceito ou das práticas das empresas, novas categorias poderão surgir. Além disso, os casos analisados são generalizações por observação de uma amostra não aleatória. Poderão surgir casos que não se enquadrem na tipologia definida. Esses casos deverão ser analisados à luz dos conceitos econômicos discutidos nesta tese.

A pesquisa empírica analisa os Relatórios de Sustentabilidade, documento não obrigatório e, em sua maioria, não auditado. Assim, outra limitação aparece pelo documento utilizado na pesquisa, pois pode haver informações distorcidas, prejudicando a validade interna da pesquisa. Como esse era o documento mais apropriado para o estudo, optou-se por utilizá-lo, apesar da limitação.

Deve-se destacar que o trabalho não avalia, em nenhuma vertente, a existência de distribuição igualitária da renda. Essa análise seria possível apenas se os impactos da ação social fossem mensurados pelas empresas. Mas elas não fazem essa análise, e é provável que a relação custo-benefício dessa informação não seja favorável para a empresa. 
Por fim, acredita-se que o trabalho tenha contribuído para aproximar a DVA dos conceitos da Contabilidade Nacional. A questão levantada dá início a uma série de possibilidades de discussão. Ainda que o valor investido atualmente pelas empresas no país represente somente cerca de $0,5 \%$ do PIB brasileiro, este tema vem crescendo, e cada vez mais empresas adotam a bandeira da sustentabilidade que inclui o tema responsabilidade social. 


\section{REFERÊNCIAS}

ACKERMAN, Robert W. How companies respond to social demands. Harvard Business Review. Boston, v. 51, n. 4, p. 88-98. Jul./Aug. 1973.

ASHLEY, Patricia Almeida; COUTINHO, Renata Buarque Goulart; TOMEI, Patricia Amélia. Responsabilidade social corporativa e cidadania empresarial: uma análise conceitual comparativa. In: Encontro Anual da Associação Nacional dos Programas de Pós-Graduação em Administração - ENANPAD, 24., 2000, Florianópolis. Anais Eletrônicos... Florianópolis: ANPAD, 2000. CD-ROM.

BANNISTER, James W.; RIAHI-BELKAOUI, Ahmed. Value Added and corporate control in US. Journal of International Financial Management and Accounting. Oxford, v. 3, p. 241-257, autumn 1991.

BAO, Ben-Hsien; BAO, Da-Hsien. An empirical investigation of the association between productivity and firm value. Journal of Business, Finance \& Accounting. Oxford, v. 16, n. 5, p. 699-717, dec. 1989.

BAO, Ben-Hsien.; BAO, Da-Hsien. The time series behavior and predictiveability results of annual value added data. Journal of Business, Finance \& Accounting. Oxford, v. 23, n.3, p. 449-460, Apr. 1996.

BAO, Ben-Hsien.; BAO, Da-Hsien. Usefulness of value added and abnormal economic earnings: an empirical examination. Journal of Business, Finance \& Accounting. Oxford, v. 25, n.1\&2, p. 251-264, Jan./Mar. 1998.

BARDIN, Laurence. Análise de Conteúdo. 3ª ed. Lisboa: Edições 70, 2004.

BERTAGNOLLI, Daniele Dias de O.; OTT, Ernani; DAMACENA, Cláudio. Estudo sobre a Influência dos Investimentos Sociais e Ambientais no Desempenho Econômico das Empresas. In: Congresso USP de Contabilidade e Controladoria, 6., 2006, São Paulo. Anais Eletrônicos... São Paulo: FIPECAFI, 2006. CD-ROM.

BITTENCOURT, Epaminondas; CARRIERI, Alexandre. Responsabilidade Social: ideologia, poder e discurso na lógica empresarial. Revista de Administração de Empresas - RAE. São Paulo, v. 45, p. 10-22, nov./dez. 2005. Edição Especial Minas Gerais.

BORBA, Paulo da Rocha Ferreira. Relação entre desempenho social corporativo e desempenho financeiro de empresas no Brasil. São Paulo, 2005. Dissertação (Mestrado em Administração) - Programa de Pós-Graduação em Administração, Departamento de Administração, Faculdade de Economia, Administração e Contabilidade da Universidade de São Paulo.

BORGER, Fernanda Gabriela. Responsabilidade Social: Efeitos da Atuação Social na Dinâmica Empresarial. São Paulo, 2001. Tese (Doutorado em Administração) - Programa 
de Pós-Graduação em Administração, Departamento de Administração, Faculdade de Economia, Administração e Contabilidade da Universidade de São Paulo.

BOWIE, Norman. New Directions in Corporate Social Responsibility. Business Horizons. New York, v. 34, n. 4, p. 56-65, July/Aug. 1991.

BRASIL. Lei Ordinária $n^{\circ} 11.638$ de 28/12/2007. Diário Oficial - República Federativa do Brasil: Poder Legislativo. Brasília, DF, 2007.

BURCHELL, Stuart; CLUBB, Colin; HOPWOOD, Anthony G. Accounting in its social context: towards a history of value added in the United Kingdom. Accounting, Organizations and Society. Oxford, v.10, n.4, p. 381-413, 1985.

CARROLL, Archie B. A Three-Dimensional Conceptual Model of Corporate Performance. The Academy of Management Review. Briarcliff Manor, v. 4, n. 4 , p. 497-505, Oct. 1979.

CARROLL, Archie B. The Pyramid of Corporate Social Responsibility: Towards the Moral Management of Organizational Stakeholders. Business Horizons. New York, v. 34, n. 4, p. 39-48, July/Aug. 1991.

CARROLL, Archie B. Social Issues in Management Research, Business and Society. Thousand Oaks, v. 33, n. 1, p. 5-25, Apr. 1994.

CARROLL, Archie B. Corporate Social Responsibility. Evolution of Definitional Construct, Business and Society. Thousand Oaks, v. 38, n. 3, p. 268-295, Sep. 1999.

CIA DE BEBIDAS IPIRANGA. Balanço Social 2006. Disponível em: $<$ http://bebidasipiranga.com.br/acao/Balanco_Social.pdf>. Acesso em 21/08/2007.

COMISSÃO DE VALORES MOBILIÁRIOS - CVM. Comunicado ao Mercado de 14/01/2008. Disponível em: <http://www.cvm.gov.br/>. Acesso em 22/02/2008.

COMITÊ DE PRONUNCIAMENTOS CONTÁBEIS - CPC. Pronunciamento Conceitual Básico - Estrutura Conceitual. 2008a. Disponível em: 〈http://www.cpc.org.br $>$. Acesso em 18/03/2008.

COMITÊ DE PRONUNCIAMENTOS CONTÁBEIS - CPC. CPC 09 - Demonstração do Valor Adicionado. 2008b. Disponível em: 〈http://www.cpc.org.br〉. Acesso em 15/12/2008.

CONSELHO FEDERAL DE CONTABILIDADE - CFC. Resolução CFC n⿳⺈. 1.010/2005 de 21/01/2005. Disponível em: <http://www.cfc.org.br/>. Acesso em 13/08/2008.

CONSELHO REGIONAL DE CONTABILIDADE DO ESTADO DE SÃO PAULO CRC/SP. Uma ação que vale um milhão. 2007. Disponível em: $<$ http://www.crcsp.org.br/portal_novo/home/crc_social/hotsite/pdf/cartilha. Acesso em 19/08/2008.

COSENZA, José Paulo. A eficácia informativa da demonstração do valor adicionado. Revista Contabilidade \& Finanças. São Paulo, ano 14, edição comemorativa, p. 7 - 29, Out. 2003. 
CUNHA, Jacqueline Veneroso Alves da. Demonstração Contábil do Valor Adicionado DVA: um instrumento de mensuração da distribuição de riqueza das empresas para os funcionários. São Paulo, 2002. Dissertação (Mestrado em Controladoria e Contabilidade) Programa de Pós-Graduação em Ciências Contábeis, Departamento de Contabilidade e Atuária, Faculdade de Economia, Administração e Contabilidade da Universidade de São Paulo.

CUNHA, Jacqueline Veneroso Alves da; RIBEIRO, Maísa de Souza; SANTOS, Ariovaldo dos. A Demonstração do Valor Adicionado como instrumento de mensuração da distribuição da riqueza. Revista Contabilidade e Finanças - USP. São Paulo, v. 1, n. 37, p. 7-23, Jan./Abr. 2005.

DAVIS, Keith. Can business afford to ignore Corporate Social Responsibilities? California Management Review. Berkeley, v. 2, p. 70-76, Spring 1960.

DAVIS, Keith. Understanding the Social Responsibility Puzzle. Business Horizons. New York, v. 10, n. 4, p. 45-51, Winter 1967.

DEEGAN, Craig. Introduction - The Legitimising effect of social and environmental disclosures - a theoretical foundation. Accounting, Auditing \& Accountability Journal. Bradford, v. 15, n. 3, p. 282-311, 2002.

DE LUCA, Márcia Martins Mendes. A contribuição da Demonstração do Valor Adicionado no processo de mensuração do PIB e em algumas análises macroeconômicas. São Paulo, 1996. Tese (Doutorado em Controladoria e Contabilidade) - Programa de PósGraduação em Ciências Contábeis, Departamento de Contabilidade e Atuária, Faculdade de Economia, Administração e Contabilidade da Universidade de São Paulo.

DE LUCA, Márcia Martins Mendes. Demonstração do Valor Adicionado: do cálculo da riqueza criada pela empresa ao valor do PIB. São Paulo: Atlas, 1998.

DE LUCA, Márcia Martins Mendes; CUNHA, Jacqueline Veneroso A.; RIBEIRO, Maísa de Souza; OLIVEIRA, Marcelle Colares. Demonstração do Valor Adicionado: do cálculo da riqueza criada pela empresa ao valor do PIB. $2^{a}$ ed. São Paulo: Atlas, 2009.

DEMO, Pedro. Metodologia científica em ciências sociais. 3. ed. 11. reimpr. São Paulo: Atlas, 2007

DONALDSON, Thomas; DUNFEE, Thomas W. Towards a Unified Conception of Business Ethics: Integrative Social Contracts Theory. The Academy of Management Review. Briarcliff Manor, v. 19, n. 2, p. 252-284, Apr. 1994.

DONALDSON, Thomas; PRESTON, Lee E. The Stakeholder Theory of the Corporation: concepts, evidence, and implications. The Academy of Management Review. Briarcliff Manor, v. 20, n. 1, p. 65-91, Jan. 1995.

EDISON. Relatório de Sustentabilidade 2006 Gruppo Edison. $<$ http://edisonsr2006it.halvarsson.se/index.aspx?p=18\#430>. Acesso em: 25/08/2007. 
ENDERLE, Georges; TAVIS, Lee A.. A Balanced Concept of the Firm and Measurement of its longterm Planning and Performance. Journal of Business Ethics. Newark, v.17, n.11, p. 1129-1144, Aug. 1998.

EVRAERT, Serge; RIAHI-BELKAOUI, Ahmed. Usefulness of Value Added Reporting: a review and synthesis of the literature. Managerial Finance. Patrington, v. 24, n. 11, p. 1-15, 1998.

EXAME. São Paulo: Abril, ano 39, n. 839, 06/2005.

EXAME. Anuário Melhores e Maiores. São Paulo: Abril, ano 42, edição especial, 07/2008.

EXAME. Anuário VOCÊ S/A EXAME As 150 melhores empresas para você trabalhar. São Paulo: Abril, ano 42, edição especial, 09/2008.

EXAME. Anuário Guia EXAME de Sustentabilidade. São Paulo: Abril, ano 42, edição especial, 10/2008.

EXAME. Anuário Melhores e Maiores. São Paulo: Abril, ano 43, edição especial, 07/2009.

FARIA, Alexandre; SAUERBRONN, Fernanda Filgueiras. A responsabilidade social é uma questão de estratégia? Uma abordagem crítica. Revista de Administração Pública - RAP. Rio de Janeiro, v. 42, n. 1, p. 07-33, Jan./Fev. 2008.

FEIJÓ Carmem Aparecida; RAMOS Roberto Luis Olinto; LIMA, Fernando Carlos G. de Cerqueira; BARBOSA FILHO, Nelson Henrique; PALIS, Rebeca. Contabilidade social: a nova referência das contas nacionais do Brasil. $2^{\mathrm{a}}$ ed. Rio de Janeiro: Elsevier, 2003.

FONTANELLE, Isleide Arruda. Responsabilidade Social e mercado da cidadania no Brasil: o caso da McInternet. In: Encontro Anual da Associação Nacional dos Programas de PósGraduação em Administração - ENANPAD, 30., 2006, Salvador. Anais Eletrônicos... Salvador: ANPAD, 2006. CD-ROM.

FREDERICK, William C. Moving to CSR4. Business and Society. Thousand Oaks, v. 37, n. 1, p. 40-60, Mar. 1998.

FREEMAN, R. Edward; REED, David L.. Stockholders and Stakeholders: A New Perspective on Corporate Governance. California Management Review. Berkeley, v. 25, n. 3, p. 88106, Spring 1983.

FREEMAN, R. Edward. The politics of stakeholder theory: some future directions. Business Ethics Quarterly. Newark, v. 4, n. 4, p. 409-429, Oct. 1994.

FREEMAN, R. Edward; PHILIPS, Robert A.. Stakeholder Theory: a libertarian defence. Business Ethics Quarterly. Newark, v. 12, n. 3, p. 331-349, Jul. 2002.

FREITAS, Maria Ester. Contexto social e imaginário organizacional moderno. RAE Revista de Administração de Empresas. São Paulo, v. 40, n. 2, p. 6-15, Abr./Jun. 2000. 
FRIEDMAN, Milton. The Social Responsibility of business is to increase its profits. New York Times. New York, p. 32-33, 13/09/1970.

FRIEDMAN, Milton. Capitalismo e liberdade. 3. ed. São Paulo: Nova Cultural, 1988.

FUNDAÇÃO INSTITUTO DE PESQUISAS CONTÁBEIS, ATUARIAIS E FINANCEIRAS (FIPECAFI). Manual de Contabilidade das Sociedades por Ações. 7. ed., São Paulo: Atlas, 2007.

GALLO, Mauro Fernando. A relevância da abordagem contábil na mensuração da carga tributária das empresas. São Paulo, 2007. Tese (Doutorado em Controladoria e Contabilidade) - Programa de Pós-Graduação em Ciências Contábeis, Departamento de Contabilidade e Atuária, Faculdade de Economia, Administração e Contabilidade da Universidade de São Paulo.

GALLO, Mauro Fernando; PEREIRA, Carlos Alberto; LIMA, Emanoel Marcos. Mensuração da carga tributária efetiva: existem divergências entre os enfoques econômico e contábil? In: Encontro Anual da Associação Nacional dos Programas de Pós-Graduação em Administração - ENANPAD, 30., 2006, Salvador. Anais Eletrônicos... Salvador: ANPAD, 2006. CD-ROM.

GARRIGA, Elisabet, MELÉ, Domènec. Corporate Social Responsibility Theories: Mapping the Territory. Journal of Business Ethics. Dordrecht, v. 53, n. 1-2, p. 51-71, Aug. 2004.

GLADWIN, Thomas N.; KENNELLY, James J.; KRAUSE, Tara-Shelomith. Shifting paradigms for sustainable development: implications for management theory and research. The Academy of Management Review. Briarcliff Manor, v. 20, n. 4, p. 874-904, Out. 1995.

GLOBAL REPORTING INICIATIVE. Diretrizes para Relatório de Sustentabilidade. Tradução: Instituto Ethos, Aberje e FGV/EAESP. 2006. Disponível em: <http://www.globalreporting.org/ReportingFramework/G3Online/LanguageSpecific/Portugue se>. Acesso em: 08/11/2007.

GRAY, Rob; KOUHY, Reza; LAVERS, Simon. Corporate social and environmental reporting: a review of the literature and a longitudinal study of UK disclosure. Accounting, Auditing and Accountability Journal. Bradford, v. 8, n. 2, p. 47-77, 1995a.

GRAY, Rob; KOUHY, Reza; LAVERS, Simon. Methodological themes: constructing a research database of social and environmental reporting by UK companies. Accounting, Auditing and Accountability Journal. Bradford, v. 8, n. 2, p. 78-101, 1995 b.

GREMAUD, Amaury Patrick; VASCONCELlOS, Marco Antônio S.; TONETO JR., Rudinei. Economia Brasileira Contamporânea. 4ª ed. São Paulo: Atlas, 2002.

GREMAUD, Amaury Patrick; TONETO JR., Rudinei. Mensurando a Economia de um país. In: GREMAUD, A. P. et al. Introdução à Economia. São Paulo: Atlas, 2007.

HALLER, Alex; STOLOWY, Hervé. Value added in financial accounting. Advances in Internacional Accounting. Burlington, v. 11, p. 23-51, 1998. 
HART, Stuart L.. A Natural-Resource-Based view of the firm. The Academy of Management Review. Briarcliff Manor, v. 20, n. 4, p. 986-1012, Oct. 1995.

HOPWOOD, Anthony G.; BURCHELL, Stuart; CLUBB, Colin. Value-added accounting and national economic policy. In: Accounting as social and institutional practice. Cambridge: Cambridge University Press, 1994.

INSTITUTO BRASILEIRO DE GEOGRAFIA E ESTATÍSTICA. Sistema de contas nacionais. $2^{\mathrm{a}}$ ed. Rio de Janeiro: IBGE, 2008a.

INSTITUTO BRASILEIRO DE GEOGRAFIA E ESTATÍSTICA. Sistema de contas nacionais: Brasil: 2002-2006. Rio de Janeiro: IBGE, 2008b.

INSTITUTO DE PESQUISA ECONÔMICA APLICADA (DIRETORIA DE ESTUDOS SOCIAIS) - IPEA/DISOC. A iniciativa privada e o espírito público: a evolução da ação social das empresas privadas no Brasil. Brasília, jul. 2006. Disponível em: $<$ http://getinternet.ipea.gov.br/asocial>. Acesso em 21/06/2008.

INTERNATIONAL ACCOUNTING STANDARDS BOARD - IASB. IAS 1 (Presentation of Financial Statements). Disponível em: <http://www.iasb.org>. Acesso em: 12/01/2008.

JENSEN, Michael C.; MECKLING, William. Theory of the firm: managerial behavior, agency costs and ownership structures. Journal of Financial Economics. Amsterdam, v. 3, n. 4, p. 305-360, Out. 1976.

JENSEN, Michael C.. Value maximization, stakeholder theory, and the corporate objective function. p. 37-58. In BEER, M.; NOHRIA, N. (eds.). Breaking the Code of Change. Boston: Harvard Business School Press, 2000. Reimpressão: Value Maximization, Stakeholder Theory, and the Corporate Objective Function. Business Ethics Quarterly. Newark, v. 12, n. 2, p. 235-256, Apr. 2002.

JONES, Thomas M.. Corporate Social Responsibility revisited, redefined. California Management Review. Berkeley, v. 22, n. 2, p. 59-67, Spring 1980.

JUSTO, Carolina Raquel Duarte de Mello. Política de transferência de renda e cidadania no Brasil: implicações político-sociais dos programas municipais de renda mínima a partir do estudo comparativo dos casos de Campinas, Jundiaí, Santo André e Santos (1995-2006). Campinas, 2007. Tese (Doutorado em Ciências Sociais) - Programa de Pós-Graduação em Ciências Sociais, Instituto de Filosofia e Ciências Humanas da Universidade Estadual de Campinas.

KARPIK, Phillip; RIAHI-BELKAOUI, Ahmed. The effect of the implementation of the multidivisional structure on shareholder's wealth: the contingency of diversification strategy. Journal of Business, Finance and Accounting. Oxford, v. 21, n.3, p. 349-365, Apr. 1994.

KITAHARA, José Renato. Responsabilidade social e desempenho financeiro das empresas: um estudo empírico utilizando o balanço social padrão iBase. São Paulo, 2007. Dissertação (Mestrado em Administração) - Programa de Pós-Graduação em Administração, Departamento de Administração, Faculdade de Economia, Administração e Contabilidade da Universidade de São Paulo. 
KLONOSKI, Richard J. Foundational Considerations in the Corporate Social Responsibility Debate. Business Horizons. New York, v. 34, n. 4, p. 9-18, July/Aug. 1991.

LEVITT, Theodore. The Dangers of Social Responsibility. Harvard Business Review. Boston, v. 36, p. 41-50, Sep-Oct. 1958.

LOGSDON, Jeanne M.; WOOD, Donna J.. Business citizenship: from domestic to global level of analysis. Business Ethics Quarterly. Newark, v. 12, n. 2, p. 155-187, April 2002.

MACEDO, Isaias C.. A Energia da Cana-de açúcar: doze estudos sobre a agroindústria da cana-de-açúcar no Brasil e a sua sustentabilidade. Macedo, Isaias C. (organizador). São Paulo: Berlendis \& Vertecchia, UNICA - União da Agroindústria Canavieira do Estado de São Paulo, 2005.

MACKE, Janaina; CARRION, Rosinha Machado. Programas sociais corporativos: a importância da abordagem transdisciplinar. In: Encontro Anual da Associação Nacional dos Programas de Pós-Graduação em Administração - ENANPAD, 30., 2006, Salvador. Anais Eletrônicos... Salvador: ANPAD, 2006. CD-ROM.

MAHON, John F.; McGOWAN, Richard A.. Searching for the common good: a processoriented approach. Business Horizons. New York, v. 34, n. 4, p. 79-86, July/Aug. 1991.

MARTINS, Eliseu. Uma nova demonstração contábil: a do "valor adicionado". Temática Contábil. Boletim IOB, n. 14, jul. 1993.

MARTINS, Gilberto de Andrade; THEÓFILO, Carlos Renato. Metodologia da investigação científica para Ciências Sociais Aplicadas. São Paulo: Atlas, 2007.

MATTEN, Dirk; CRANE, Andrew; CHAPPLE, Wendy. Behind the mask: revealing the true face of Corporate Citizenship. Journal of Business Ethics. Dordrecht, v. 45, n.1-2, p. 109120, jun. 2003.

McLEAY, Stuart. Value added: a comparative study. Accounting, Organizations and Society. Oxford, v. 8, n. 1, p. 31-56, Mar. 1983.

McWILLIAMS, Abagail; SIEGEL, Donald. Corporate social responsibility: A theory of the firm perspective. The Academy of Management Review. Briarcliff Manor, v. 26, n. 1, p. 117-127, Jan. 2001.

MEEK, Gary K.; GRAY Sidney J.. The Value Added Statement: an innovation for U.S. companies? Accounting Horizons. Sarasota, v. 2, n. 2, p. 73-81, jun. 1988.

MENDONÇA, Luciana Rocha de. A decisão entre manter as práticas de atuação social vinculadas à estrutura organizacional ou constituir uma fundação ou instituto. São Paulo, 2003. Dissertação (Mestrado em Administração) - Programa de Pós-Graduação em Administração, Departamento de Administração, Faculdade de Economia, Administração e Contabilidade da Universidade de São Paulo. 
MITCHELL, Ronald. K.; AGLE, Bradley R.; WOOD, Donna J.. Toward a theory of stakeholder identification and salience: defining the principle of who and what really counts. The Academy of Management Review. Briarcliff Manor, v. 22, n. 4, p. 853-886, Oct. 1997.

MONEVA, José M.; ARCHEL, Pablo; CORREA, Carmen. GRI and the camouflaging of corporate unsustainability. Accounting Forum. Orlando, v. 30, n.2, p. 121-137, June 2006.

MORLEY, Michael F.. The Value Added Statement in Britain. The Accounting Review. Sarasota, v.54, n.3, p. 618-629, Jul. 1979.

NUNES, Eduardo Pereira. Sistema de Contas Nacionais: a gênese das contas nacionais modernas e a evolução das contas nacionais no Brasil. Campinas, 1998. Tese (Doutorado em Economia) - Programa de Pós-Graduação em Economia, Instituto de Economia da Universidade Estadual de Campinas.

OLIVEIRA, Juliana Godoi de. Análise da divulgação da DVA no cenário internacional. Ribeirão Preto, 2008. Trabalho de Conclusão de Curso (Graduação em Ciências Contábeis) Departamento de Contabilidade, Faculdade de Economia, Administração e Contabilidade de Ribeirão Preto da Universidade de São Paulo.

PASSADOR, Cláudia Souza; FERRAZ, Maitê Garcia Leal. The creation of a new concept: the Eco-social Economic Responsibility. In: International PENSA Conference, 6., 2007, Ribeirão Preto. Anais Eletrônicos... Ribeirão Preto: FUNDACE, 2007. CD-ROM.

PAUlANI, Leda Maria, BRAGA, Márcio Bobik. A Nova Contabilidade Social: uma introdução à macroeconomia. 2. ed. São Paulo: Saraiva, 2007.

PELIANO, Anna Maria T. Medeiros. Bondade ou interesse? Como e por que as empresas atuam na área social. Anna Maria T. Medeiros Peliano (coord.). Brasília: IPEA, 2001.

PEREIRA, Luiz Carlos Bresser. Reforma do estado para a cidadania: a reforma gerencial brasileira na perspectiva internacional. Brasília: ENAP, 1998.

PEREIRA, Wolney Afonso; CAMPOS FILHO, Luiz Alberto Nascimento. Investigação sobre as semelhanças entre os modelos conceituais da Responsabilidade Social Corporativa. In: Encontro Anual da Associação Nacional dos Programas de Pós-Graduação em Administração - ENANPAD, 30., 2006, Salvador. Anais Eletrônicos... Salvador: ANPAD, 2006. CD-ROM.

PHILLIPS, Robert A. Stakeholder Legitimacy. Business Ethics Quarterly. Newark, v. 13, n. 1, p. 25-41, Jan. 2003.

PHILLIPS, Robert A. FREEMAN, R. Edward; WICKS, Andrew C.. What stakeholder theory is not. Business Ethics Quarterly. Newark, v. 13, n. 4, p. 479-502, Oct. 2003.

PICUR, Ronald D. The effects of accounting knowledge on the omission of value added information in wealth measurement and distribution decisions. Review of Accounting and Finance. Patrington, v. 6, n. 1, p. 15-23, 2007. 
PONG, Chris; MITCHELL, Falconer. Accounting for a disappearance: a contribution to the history of the value added statement in the UK. Accounting Historians Journal. University Heights, v. 32, n. 2, p. 173-199. Dec. 2005.

PORTER, Michael E.; KRAMER, Mark R.. A vantagem competitiva da filantropia corporativa. Harvard Business Review. São Paulo, v. 80, n. 12, p. 43-54, dez. 2002.

PRESTON, L. E.; POST, J. E. Private Management and Public Policy, California Management Review. Berkeley, v. 23, n. 3, p. 56-63, Spring 1981.

QUAZI, Ali M.; O'BRIEN, Dennis. An empirical Test of a Cross-National Model of Corporate Social Responsibility. Journal of Business Ethics. Dordrecht, v. 25, n.1, p. 33-51, May 2000.

RIAHI-BELKAOUI, Ahmed. The information content of value added, earnings, and cash flow: US evidence. International Journal of Accountancy. Illinois, v. 28, p. 140-146, 1993.

RIAHI-BELKAOUI, Ahmed. Earnings-returns relation versus net-value-added-returns relation: the case for a nonlinear specification. Advances in Quantitative Analysis of Finance and Accounting. Chapel Hill, v. 4, p. 175-185, 1996.

RIAHI-BELKAOUI, Ahmed. Net Value Added and Earnings Determination. Review of Quantitative Finance and Accounting. Boston, v. 13, n. 4, p. 393-399. Dec. 1999.

RIAHI-BELKAOUI, Ahmed; FREKAT, M. Ali. The magic in value added: merits of derived accounting indicator numbers. Managerial Finance. Patrington, v. 20, n. 9, p. 3-15, 1994.

RIAHI-BELKAOUI, Ahmed; PICUR, Ronald D. Explaining market returns: earnings versus value added data. Managerial Finance. Patrington, v. 20, n. 9, p. 44-55, 1994.

RIBEIRO, Maísa de Souza; CUNHA, Jacqueline Veneroso A. O papel da demonstração do valor adicionado na avaliação da responsabilidade social das empresas. In: Congresso USP de Contabilidade e Controladoria, 3ㅇ, 2003, São Paulo. Anais Eletrônicos... São Paulo: FIPECAFI, 2003. CD-ROM.

RIBEIRO, Maísa de Souza. Contabilidade Ambiental. São Paulo: Saraiva, 2006.

RICHARDSON, Roberto J.. Pesquisa Social: Métodos e Técnicas. São Paulo: Atlas, 1999.

RODRIGUES, Fernanda Fernandes; MELLO, Maria Celeste B. de; LUSTOSA, Paulo Roberto Barbosa. Valor Adicionado Bruto ou Valor Adicionado Líquido: o Tratamento da Depreciação na Demonstração do Valor Adicionado. In: Encontro Anual da Associação Nacional dos Programas de Pós-Graduação em Administração - ENANPAD, XXXI., 2007, Rio de Janeiro. Anais Eletrônicos... Rio de Janeiro: ANPAD, 2007. CD-ROM.

RODRIGUES JÚNIOR, Manuel Salgueiro. A DVA como instrumento para mensuração da relação custo-benefício na concessão de incentivos fiscais: um estudo de casos. São Paulo, 2003. Dissertação (Mestrado em Ciências Contábeis) - Programa de Pós-Graduação em Ciências Contábeis, Departamento de Contabilidade e Atuária, Faculdade de Economia, Administração e Contabilidade da Universidade de São Paulo. 
ROVER, Suliani; MURCIA, Fernando Dal-Ri; BORBA, José Alonso. Divulgação de informações ambientais nas demonstrações contábeis: um estudo exploratório sobre o disclosure das empresas brasileiras pertencentes a setores de alto impacto ambiental. In: Encontro Anual da Associação Nacional dos Programas de Pós-Graduação em Contabilidade - ANPCONT, II., 2008, Gramado. Anais Eletrônicos... Gramado: ANPAD, 2008. CD-ROM.

SAMUELSON, Paul A.; NORDHAUS, William D. Economia. 14. ed. Lisboa: McGraw-Hill, 1993.

SANTOS, Ariovaldo dos; HASHIMOTO, Hugo. Demonstração do valor adicionado: algumas considerações sobre carga tributária. Revista de Administração da USP - RAUSP. São Paulo, v.38, n.2, p.153-164, Abr./Jun. 2003.

SANTOS, Ariovaldo dos; CARVALHO, L. Nelson. DVA, uma forma de avaliar a criação de riqueza. Revista Exame. São Paulo, p. 132-133, Set. 1997. Anuário Melhores e Maiores.

SANTOS, Ariovaldo dos. Demonstração Contábil do Valor Adicionado - DVA: um instrumento para medição da geração e distribuição de riqueza das empresas. São Paulo, 1999. Tese (Livre Docência) - Departamento de Contabilidade e Atuária, Faculdade de Economia, Administração e Contabilidade, Universidade de São Paulo.

SANTOS, Ariovaldo dos. Demonstração do Valor Adicionado: como elaborar e analisar a DVA. São Paulo: Atlas, 2003.

SANTOS, Ariovaldo dos. DVA - Uma demonstração que veio para ficar. Revista Contabilidade e Finanças - USP. São Paulo, n. 38, p. 3-6, maio/ago. 2005.

SCHERER, Luciano Márcio. Valor Adicionado: análise empírica de sua relevância para as companhias abertas que publicam a demonstração do valor adicionado. São Paulo, 2006. Tese (Doutorado em Controladoria e Contabilidade) - Programa de Pós-Graduação em Ciências Contábeis, Departamento de Contabilidade e Atuária, Faculdade de Economia, Administração e Contabilidade da Universidade de São Paulo.

SCHOMMER, Paula Chies. Investimento social das empresas: cooperação organizacional num espaço compartilhado. Organizações \& Sociedade. Salvador, v. 7, n. 19, p. 145-160, set./dez. 2000.

SELEKMAN, Benjamin Morris. A moral philosophy for management. New York: McGrawHill, 1959.

SETHI, S. Prakash. Dimensions of corporate social performance: an analytical framework, Califórnia Management Review. Berkeley, v. 17, n. 3, p. 58-65, Spring 1975.

SILVA FILHO, Geraldo Andrade. Auto-interesse Versus Considerações Morais: evidências da economia experimental. São Paulo, 2000. Dissertação (Mestrado em Economia) - Programa de Pós-Graduação em Economia, Departamento de Economia, Faculdade de Economia, Administração e Contabilidade da Universidade de São Paulo. 
SIMONSEN, Mário Henrique; CYSNE, Rubens Penha. Macroeconomia. 3. ed. São Paulo: Atlas, 2007.

SINGAPORE PRESS HOLDINGS. Annual Report 2006. Obtido em: <http://www.sph.com.sg/invrel/files/2006/p_54.pdf>. Acesso em: 18/08/2007.

SIQUEIRA, José Ricardo Maia de; VIDAL, Mario Cesar Rodríguez. Balanços Sociais brasileiros: uma análise de seu estágio atual. In: Congresso USP de Contabilidade e Controladoria, $3^{\text {o }}$, 2003, São Paulo. Anais Eletrônicos... São Paulo: FIPECAFI, 2003. CDROM.

SOUSA FILHO, José Milton; WANDERLEY, Lilian Soares Outtes. Divulgação da Responsabilidade Social Empresarial: como os websites empresariais vêm sendo utilizados por empresas de energia e varejo. In: Encontro Anual da Associação Nacional dos Programas de Pós-Graduação em Administração - ENANPAD, 30., 2006, Salvador. Anais Eletrônicos... Salvador: ANPAD, 2006. CD-ROM.

SROUR, Robert Henry. Poder, cultura e ética nas organizações. 2. ed. 2. reimpr. Rio de Janeiro: Campus, 2005.

STIGLITZ, Joseph E. Economics of the Public Sector. 3rd ed. New York: Norton, 2000.

STIGLITZ, Joseph E; SEN, Amartya; FITOUSSI, Jean-Paul. Report by the Commission on the Measurement of Economic Performance and Social Progress. 2009. Disponível em: <http://www.stiglitz-sen-fitoussi.fr/en/index.htm>. Acesso em 19/09/09.

SUOJANEN, Waino W. Accouning theory and the large corporation. The Accounting Review. Sarasota, v. 29, n. 3, p. 391-398. Jul. 1954.

TINOCO, João Eduardo P. Balanço Social: uma abordagem da transparência e da responsabilidade pública das organizações. São Paulo: Atlas, 2006.

UNILEVER UK. Sustainability Report. Obtido em: 〈http://www.unilever.co.uk>. Acesso em: 18/08/2007.

VAN STADEN, Chris J. The usefulness of the value added statement in South Africa. Managerial Finance. Patrington, v. 24, n. 11, p. 44-59, 1998.

VAN STADEN, Chris J. The value added statement: bastion of social report or dinosaur of financial reporting?. Working Paper Massey University, Palmerston North. Obtido em: <http://papers.ssrn.com/sol3/papers.cfm?abstract_id=611302>. Acesso em: 11/01/2008.

VAN STADEN, Chris J. The relevance of theories of political economy to the understanding of financial reporting in South Africa: the case of value added statements. Accounting Forum. Orlando, v. 27, n. 2, p. 224-245, June 2003.

VARADARAJAN, P. Rajan; MENON, Anil. Cause-related marketing: a coalignment of marketing strategy and corporate philanthropy, Journal of Marketing. New York, v. 52, n. 3, p. 58-58, July 1988. 
VELASQUEZ, Manuel. International Business, Morality and the Common Good. Business Ethics Quarterly. Newark, v. 2, n. 1, p. 27-40, Jan. 1992.

VENTURA, Elvira Cruvinel Ferreira. Responsabilidade Social das empresas sob a óptica do "Novo Espírito do Capitalismo". In: Encontro Anual da Associação Nacional dos Programas de Pós-Graduação em Administração - ENANPAD, 27., 2003, Atibaia. Anais Eletrônicos... Atibaia: ANPAD, 2003. CD-ROM.

VERRECCHIA, Robert E. Essays on disclosure. Journal of Accounting and Economics. Amsterdam, v. 32, n.1-3, p. 97-180, Dec. 2001.

VOGEL, D. The study of social issues in management: a critical appraisal, California Management Review. Berkeley, v. 28, n. 2, p. 142-152, Spring 1986.

WARTICK, Steven.; COCHRAN, Philip L. The evolution of corporate social performance model. The Academy of Management Review. Briarcliff Manor, v. 10, n. 4, p. 758-769, Oct. 1985.

WARTICK, Steven L.; RUDE. Robert E. Issues Management: Corporate Fad or Corporate Function?. California Management Review. Berkeley, v. 29, n. 1, p. 124-132, Fall 1986.

WARTICK, Steven L.; MAHON, John F.. Towards a substantive definition of the corporate issue construct: a review and synthesis of literature. Business and Society. Thousand Oaks, v. 33, n. 3, p. 293-311, Dec. 1994.

WATTS, Ross L.; ZIMMERMAN, Jerold L. Towards a Positive Theory of the Determinants of Accounting Standards. The Accounting Review. Sarasota, v. 53, n. 1, p. 112-134, Jan. 1978.

WOOD, Donna J. Corporate social performance revisited. The Academy of Management Review. Briarcliff Manor, v. 16, n. 4, p. 691- 718. Oct. 1991.

YOUNG, S. David; O'BYRNE, Stephen F. EVA e Gestão Baseada em Valor: Guia prático para implementação. Porto Alegre: Bookman, 2003.

YOSHIOCA, Ricardo. Valor Adicionado: alguns conceitos econômicos que ajudam a entender a demonstração contábil. Temática Contábil - Boletim IOB, n. 8/98. 


\section{APÊNDICES}

Apêndice 1 - Roteiro de Análise dos Relatórios Sociais

Apêndice 2 - Estrutura dos relatórios analisados no estudo empírico

Apêndice 3 - Gráficos da análise dos investimentos socioambientais por empresa

Apêndice 4 - Roteiro de Entrevista para Validação da Tipologia de Investimentos Socioambientais

Apêndice 5 - Roteiro de Entrevista para Validação dos Resultados

Apêndice 6 - Tipologia usada nas entrevistas de validação do estudo empírico 


\section{Apêndice 1 - Roteiro de análise dos Relatórios de Sustentabilidade}

\section{$\underline{\text { Roteiro de análise dos Relatórios de Sustentabilidade }}$}

As instruções e critérios de avaliação estão entre colchetes, [...], ao lado de cada tópico.

A. Sobre a empresa [se necessário, buscar informações deste tópico - apenas deste tópico - no website da empresa ou em seu Relatório Financeiro]

1. Qual a nacionalidade do controle da empresa? [considerar a origem informada na edição 2008 do anuário EXAME Melhores e Maiores]

2. Quantas pessoas a empresa declarou empregar no Relatório Social 2007 ?

a. Número de empregados [no final do período]

b. Número de empregados terceirizados [no final do período]

3. Qual a receita líquida no ano 2007? [em milhões de $\mathrm{R} \$$ ]

4. Qual a margem líquida da empresa em 2007? [lucro líquido dividido por receita líquida]

5. Qual o valor total do ativo consolidado em 2007? [em milhões de R \$]

6. Relatório Social está agregado ao Relatório Anual? [usar site da empresa como referência]

\section{B. Sobre a estrutura do Relatório}

1. O Relatório divulga o modelo Ibase de Balanço Social? [considerar a divulgação da tabela padronizada Ibase]

2. O Relatório segue os padrões GRI de Balanço Social? [considerar a divulgação do índice de indicadores GRI]

3. Qual o nível de aderência ao GRI declarado no relatório?

4. Relatório Social foi auditado? [considerar o relatório auditado quando houver parecer dos auditores independentes sobre o relatório social ou quando houver declaração de garantia das informações divulgadas]

5. O Relatório está estruturado conforme as quatro vertentes do Balanço Social? [observar pela estrutura do relatório - sumário - Recursos Humanos, DVA, Balanço Ambiental, Relação com a Comunidade] 
6. Qual o número de páginas do Relatório analisado?

7. Qual o número de parágrafos analisados no Relatório?

[copiar em planilha separada o sumário de todos os Relatórios analisados]

C. Sobre as informações divulgadas [para cada gráfico, parágrafo e tabela classificar a informação conforme os quesitos abaixo]

[marcar apenas uma opção em todos os quesitos]

\section{$\underline{\text { I. Critérios que não envolvem julgamento do pesquisador }}$}

C.1. Quanto ao formato:

1. texto

2. forma gráfica [considerar gráficos e fluxogramas]

3. tabela ou quadro

C.2. Quanto à qualidade da informação:

1. quantitativa monetária

2. quantitativa não monetária

3. quantitativa monetária e não monetária

4. declarativa [todas as informações não quantitativas serão declarativas, exceto as informações técnicas sobre o relatório]

5. informação técnica sobre o próprio relatório

[se a resposta para C.2. for igual a 5, parar a análise do parágrafo aqui]

C.3. Quanto ao conteúdo da informação:

1. informações históricas da organização

2. informações sobre atividades referentes ao ano 2007 [seja em planejamento, execução ou avaliação nesse período]

3. informações do ambiente externo da organização que contextualizam as atividades de 2007

[se a resposta para C.3. for diferente de 2, parar a análise do parágrafo aqui]

C.4. Quanto à efetividade da atividade informada: 
1. valores [quando a informação refere-se a valores morais, códigos de condutas e políticas da empresa]

2. práticas [quando a informação refere-se a ações operacionais, sociais ou ambientais efetivamente praticadas pela empresa]

3. intenções [quando a informação refere-se a intenções futuras de adoção ou mudança de práticas ou políticas]

C.5. Quanto à etapa de desenvolvimento da atividade:

1. planejamento [quando a informação refere-se ao planejamento de atividade - seja valores, práticas ou intenções - ainda não executada]

2. execução [quando a informação refere-se à implementação, isto é, à execução da atividade]

3. avaliação [quando a informação refere-se à avaliação (resultados) ou controle de atividade já executada]

C.6. Quanto à categoria da informação: [marcar categoria e subcategoria, por exemplo, 2b tentar não classificar nada em outros e quando o fizer anotar no bloco de notas]

\section{Recursos Humanos}

a. Dados sobre quantidades de empregados [inclusive por diferentes idades, etnias e gêneros]

b. Avaliação de desempenho e ambiente de trabalho

c. Prêmios, benefícios, incentivos, planos de carreira e políticas salariais [exceto participação nos lucros e prêmios em ações]

d. Treinamentos e cursos de capacitação para empregados [exceto em temas relacionados ao meio ambiente, saúde e segurança no trabalho]

e. Previdência dos empregados

f. Emprego de minorias e/ou deficientes

g. Saúde e segurança no trabalho [inclui treinamentos em temas de meio ambiente]

h. Engajamento dos empregados nas decisões da empresa [ações que incentivem a participação de empregados nos processo decisórios e/ou informem os empregados sobre as decisões da empresa] 
i. Participação nos lucros, prêmios em ações ou opções de compra de ações da empresa, incentivos para compra de ações

j. Informações de conjuntura com seus impactos nos empregados da empresa.

2. Meio Ambiente

a. Realização de projetos ambientais em parceria com outras instituições, públicas ou privadas

b. Políticas Ambientais da empresa [inclui informações de conjuntura com seus impactos nas decisões tomadas pela empresa]

c. Sistemas de Gerenciamento Ambiental [procedimentos incluídos no processo operacional da empresa com o objetivo de melhorar sua relação com o meio ambiente]

d. Impactos dos Produtos e Processos [inclusive uso da água e energia e passivos ambientais]

e. Investimentos em ativos ambientais [considerar ativo ambiental os bens e direitos que tenham capacidade de geração de benefício econômico em períodos futuros e que visem à preservação, proteção e recuperação ambiental (RIBEIRO, 2006, p. 61)]

f. Educação, Pesquisa e Treinamento [exceto para empregados da empresa]

g. Mercado de Créditos de Carbono

3. Comunidade

a. Realização de projetos sociais na comunidade

b. Doações em espécie para projetos sociais da comunidade

c. Doações de bens e mercadorias (ou serviços) para a comunidade

d. Voluntariado empresarial quando o apoio da empresa for evidente

e. Patrocínios a escolas, artes e esportes

f. Parcerias público-privadas quando o beneficiário for a comunidade

g. Doações para o governo

h. Doações para campanhas políticas

4. Demonstração do Valor Adicionado [mesmo que as informações da DVA estejam desmembradas no Relatório]

5. Consumidores

a. Segurança do produto e para o consumidor

b. Serviços de atendimento ao consumidor

c. Atendimento especial para consumidores deficientes e idosos 
d. Atendimento especial para consumidores afastados dos grandes centros comerciais

6. Empresa

a. Desempenho Financeiro

b. Desempenho Mercadológico [informações sobre crescimento da empresa, participação de mercado, campanhas publicitárias etc.]

c. Processo operacional [quando a informação refere-se ao processo de produção da empresa em sua operação principal - considerar informações de empregados e meio ambiente nos tópicos anteriores]

d. Desempenho Socioambiental [apenas quando a empresa declara prêmios recebidos pela atuação socioambiental da empresa como um todo]

e. Políticas e valores da empresa [quando relacionada apenas à operação da empresa e seu contexto - não envolvem políticas e valores com empregados, meio ambiente ou ações com a comunidade]

f. Desenvolvimento ou venda de produtos com forte apelo socioambiental

7. Adoção de objetivos globais de sustentabilidade [classificar aqui as declarações de anuência a políticas nacionais ou globais - não desenvolvidas pela empresa como: Objetivos do Milênio, Princípios do Equador, Pacto Global etc.]

8. Outros [sempre que houver classificação nesse grupo, registrar o evento no bloco de anotações]

\section{Critérios que envolvem julgamento do pesquisador}

[apenas para os parágrafos classificados como 2 (práticas) no quesito $\mathrm{C} 4$ e classificados como 1, 2 ou 3 no quesito C6]

C.7. Quanto ao relacionamento da atividade com o processo produtivo:

1. atividade refere-se a práticas relacionadas a pessoas que trabalham direta ou indiretamente no processo produtivo da empresa

2. atividade refere-se aos produtos e serviços produzidos pela empresa em qualquer etapa de seu ciclo de vida [por ciclo de vida, entende-se desde a produção pelos fornecedores da matéria-prima utilizada no processo produtivo até o descarte do produto - e de suas embalagens - pelo consumidor final]

3. atividade refere-se ao consumo de recursos ou emissão de resíduos durante o processo produtivo da empresa 
4. atividade refere-se a práticas, na comunidade ou com seu público interno, relacionadas com impactos (passados, presentes ou futuros) gerados pela própria empresa (e seu processo produtivo) na sociedade [quando a empresa age para “compensar” prejuízos causados por ela - alguns exemplos: empresa poluidora que investe em educação ambiental; empresa em fase de mecanização - portanto gerando desemprego - que investe em capacitação; empresa produtora de alimentos industrializados que investem em programas de educação alimentar]

5. atividade não está relacionada, em nenhuma vertente, ao processo produtivo da empresa

C.8. Quanto à "notícia” divulgada pela informação:

1. informação neutra [quando o crédito ou descrédito da notícia para a imagem da organização não for evidente]

2. informação boa [quando for evidente o crédito da notícia para a imagem da organização]

3. informação ruim [quando for evidente o descrédito da notícia para a imagem da organização]

C. 9. Quanto ao dispêndio por parte da empresa: [ainda que a empresa não tenha informado valores monetários]

1. a atividade envolve dispêndio monetário direto por parte da empresa

2. a atividade envolve dispêndio para a empresa em horas de trabalho dos empregados

3. a atividade envolve dispêndio de recursos do imobilizado da empresa

4. a atividade envolve dispêndio de estoques da empresa

5. a atividade não envolve nenhum tipo de dispêndio da empresa

C.10. Quanto à transferência de recursos (monetários ou patrimoniais) da empresa para a atividade declarada:

1. ocorre pagamento direto para uma pessoa física em troca de serviços prestados

2. ocorre transferência de recursos (doação) para uma pessoa jurídica sem fins lucrativos

3. ocorre transferência de recursos para uma pessoa jurídica sem fins lucrativos realizar atividade pré-definida 
4. ocorre pagamento para uma pessoa jurídica com fins lucrativos por produto ou serviço adquirido

5. não é possível identificar como a transferência é realizada

1. não há transferência de recursos

C.11. Quanto à possibilidade de auditar a informação: [considerar a hipótese de a empresa permitir acesso aos dados]

1. auditável [quando é viável desenvolver metodologia de verificação da informação]

2. não auditável [quando não é viável desenvolver metodologia de verificação da informação]

Esta metodologia foi baseada em Gray, Kouhy e Lavers (1995a e 1995b); Macke e Carrion (2006); Sousa Filho e Wanderley (2006); Rover, Múrcia e Borba (2008). 


\section{Apêndice 2 - Estrutura dos relatórios analisados no estudo empírico}

\begin{tabular}{|c|c|c|}
\hline AES Tietê & Ambev & Anhanguera Educação \\
\hline \multirow{8}{*}{$\begin{array}{l}\text { Introdução } \\
\text { Mensagem do Presidente } \\
\text { Perfil } \\
\text { Excelência em Gestão } \\
\text { Reconhecimentos } \\
\text { Governança Corporativa } \\
\text { Públicos de Relacionamento } \\
\text { Desempenho Econômico-financeiro }\end{array}$} & Mensagem da Administração & Anhanguera \\
\hline & Perfil & Extensão Comunitária \\
\hline & - Missão, Visão e Cultura & - Projetos na área de Educação \\
\hline & - Estratégia e estrutura de & - Inclusão Digital \\
\hline & responsabilidade social & - Capacitação para o Trabalho \\
\hline & - Mapeamento dos stakeholders & - Assistência Jurídica \\
\hline & - Reconhecimento externo & - Saúde \\
\hline & Sobre o relatório & - Esporte, Lazer e Saúde \\
\hline Desempenho & Governança corporativa & - Saúde Animal \\
\hline Operacional & Gente & - Cultura \\
\hline Gestão Ambiental & - Emprego & - Campanhas Assistenciais \\
\hline Gestão Social & - Remuneração e beneficios & - Dia Nacional da RS do Ensino \\
\hline Índice Remissivo & - Saúde e segurança & Superior Particular \\
\hline Créditos & - Treinamento e educação & Meio Ambiente \\
\hline & - Relações com a empresa & Alunos \\
\hline & Gestão ambiental & - Bolsas de Estudo \\
\hline & - Materiais & - Inovação e Pioneirismo \\
\hline & - Energia & - Programa Livro-Texto \\
\hline & - Emissões atmosféricas & - Avaliação de Qualidade \\
\hline & - Agua & - Programa de Inıciaçao Cientifica \\
\hline & - Biodiversidade & - Atividades Acadêmicas \\
\hline & - Conformidade & Público Interno \\
\hline & Sociedade & - Carreira Docente \\
\hline & - Consumidores & - Programa Permanente \\
\hline & - Clientes & Capacitação Docente \\
\hline & - Comunidade & - Educação \\
\hline & - Fornecedores & - Diversidade \\
\hline & - Governo e sociedade & - Saúde e Qualidade de Vida \\
\hline & Sumário GRI & - Eventos de Integração \\
\hline & & Resultados \\
\hline
\end{tabular}




\begin{tabular}{|c|c|c|}
\hline Bradesco & Braskem & CCR Rodovias \\
\hline $\begin{array}{l}\text { Mensagem do Presidente } \\
\text { Perfil } \\
\text { Visão de Sustentabilidade } \\
\text { - Banco do Planeta } \\
\text { - Responsabilidade Socioambiental } \\
\text { - Finanças Sustentáveis } \\
\text { Desempenho Econômico } \\
\text { Relacionamento com as Partes } \\
\text { Interessadas } \\
\text { Acionistas e Investidores } \\
\text { Clientes } \\
\text { Público Interno } \\
\text { Fornecedores } \\
\text { Comunidade } \\
\text { Governo e Sociedade } \\
\text { Meio Ambiente } \\
\text { Fundação Bradesco } \\
\text { Finasa Esportes } \\
\text { Balanço Social Ibase } \\
\text { Relato de Sustentabilidade e Índice } \\
\text { GRI } \\
\text { Declaração de Garantia } \\
\text { Relatório dos Auditores } \\
\text { Independentes }\end{array}$ & $\begin{array}{l}\text { Mensagem dos Administradores } \\
\text { Visão Estratégica } \\
\text { Responsabilidade Econômico- } \\
\text { financeira } \\
\text { Responsabilidade Social } \\
\text { Responsabilidade Ambiental } \\
\text { Indicadores de Desempenho e } \\
\text { Ecoeficiência } \\
\text { Balanço Social - Modelo Ibase }\end{array}$ & $\begin{array}{l}\text { Mensagem da Administração } \\
\text { O Grupo CCR } \\
\text { Visão de Sustentabilidade } \\
\text { Governança Corporativa } \\
\text { Públicos Estratégicos } \\
\text { - Acionistas e Investidores } \\
\text { - Usuários } \\
\text { - Público Interno } \\
\text { - Fornecedores } \\
\text { - Concorrentes } \\
\text { - Comunidade } \\
\text { - Governo e Sociedade } \\
\text { - Meio Ambiente } \\
\text { Balanço Social - Ibase } \\
\text { Relato da Sustentabilidade } \\
\text { - Índice GRI } \\
\text { Contatos e Endereços }\end{array}$ \\
\hline
\end{tabular}




\begin{tabular}{|c|c|c|}
\hline Celulose Irani & CPFL & CTBC \\
\hline 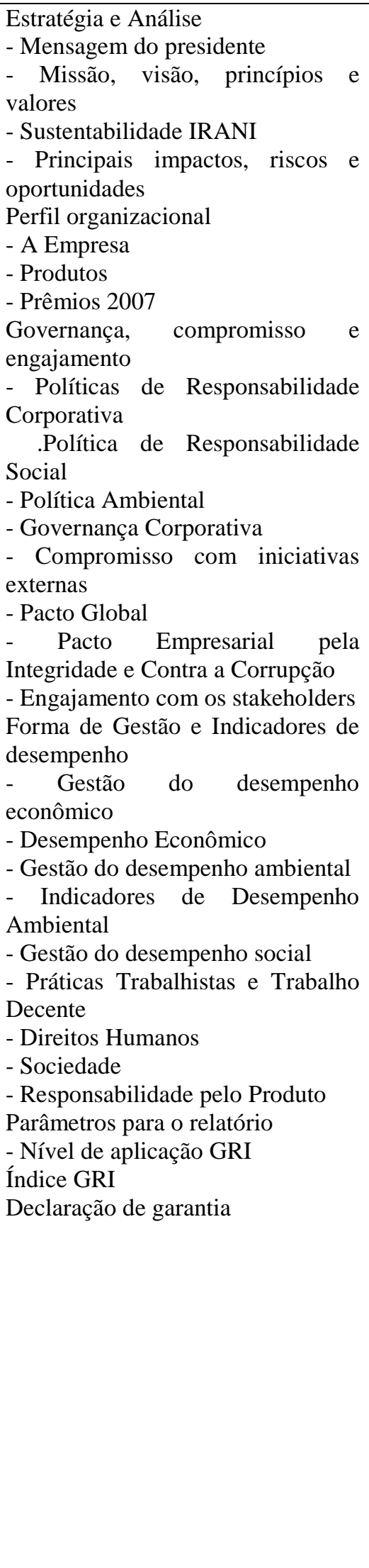 & 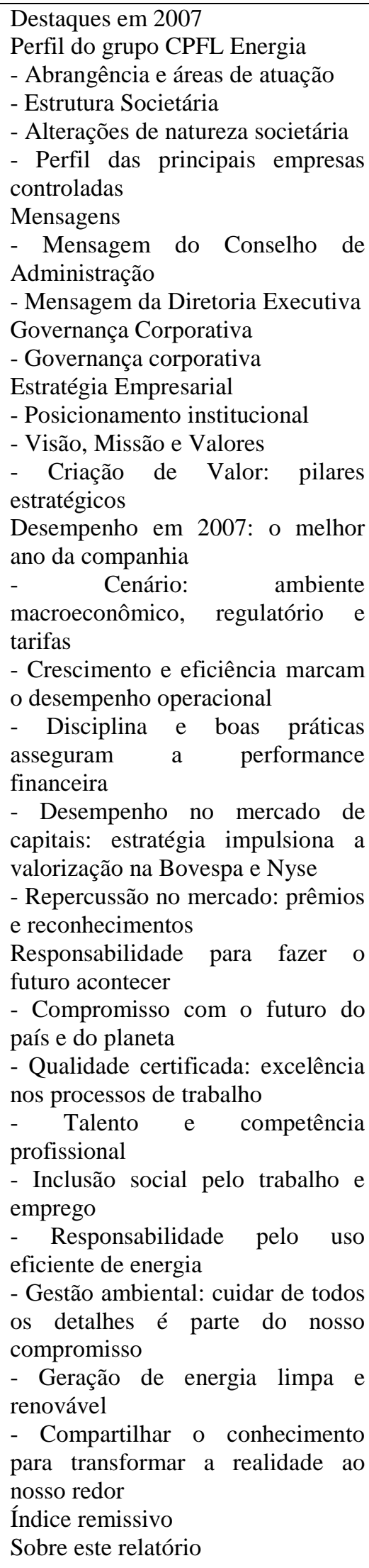 & $\begin{array}{l}\text { Histórico } \\
\text { Mensagem da Administração } \\
\text { Perfil Corporativo } \\
\text { Governança Corporativa } \\
\text { Gestão e Estratégia } \\
\text { Ativos Intangíveis } \\
\text { Desempenho dos Negócios } \\
\text { Desempenho Econômico e } \\
\text { Financeiro } \\
\text { Perspectivas } \\
\text { Responsabilidade Socioambiental } \\
\text { Indicadores GRI } \\
\text { Informações Corporativas } \\
\text { Expediente }\end{array}$ \\
\hline
\end{tabular}




\begin{tabular}{|c|c|c|}
\hline Duratex & Elektro & Gol \\
\hline $\begin{array}{l}\text { Mensagem do Presidente } \\
\text { Governança Corporativa } \\
\text { Gestão Estratégica e Investimentos } \\
\text { Vantagens Competitivas } \\
\text { Divisão Madeira } \\
\text { Divisão Deca } \\
\text { Análise dos Resultados } \\
\text { Ações como Investimento } \\
\text { Gestão de Riscos } \\
\text { Gestão de Pessoas } \\
\text { Atuação Estratégica } \\
\text { Gestão Ambiental } \\
\text { Balanço Social Anual } 2007 \\
\text { Sumário GRI } \\
\text { Informações Corporativas } \\
\text { Créditos } \\
\text { Demonstracões Financeiras }\end{array}$ & $\begin{array}{l}\text { Introdução } \\
\text { Mensagem do Presidente } \\
\text { Perfil } \\
\text { Gestão } \\
\text { Segurança } \\
\text { Desempenho Comercial } \\
\text { Desempenho Operacional } \\
\text { Desempenho Econômico e } \\
\text { Financeiro } \\
\text { Desempenho Ambiental } \\
\text { Relacionamento com Públicos } \\
\text { Estratégicos } \\
\text { Ativos Intangíveis } \\
\text { Sumário GRI e Anexos } \\
\text { Informações Corporativas } \\
\text { Demonstrações Financeiras }\end{array}$ & $\begin{array}{l}\text { Perfil } \\
\text { Missão, Visão e Valores } \\
\text { Mensagem do Presidente } \\
\text { Desempenho Social } \\
\text { Desempenho Ambiental } \\
\text { Indicadores Sócio-Econômicos } \\
\text { Prêmios e Reconhecimentos } \\
\text { Informações Corporativas }\end{array}$ \\
\hline
\end{tabular}

\begin{tabular}{|l|l|l|}
\hline Karsten & Metal Leve (Mahle) & Natura \\
\hline Missão, Visão e Valores & Introdução & Razão de Ser \\
Mensagem do Presidente & Perfil da Empresa & Visão e Crenças \\
Educação Corporativa e Cidadania & Indicadores Sociais Internos & Mensagem da Presidência \\
Corporativa & Qualidade de Vida & Perfil \\
- Benefícios & Indicadores Sociais Externos & Estratégia e Gestão \\
- Desenvolvimentos De Talentos & Indicadores Ambientais & Governança Corporativa \\
- Gestão De Pessoas & Indicadores do Corpo Funcional & Qualidade das Relações \\
Demonstração Financeira & Unidades & Desempenho \\
& & Demonstrações Financeiras \\
& & Sobre o Relatório \\
& & \\
& & \\
& & \\
\hline
\end{tabular}

\begin{tabular}{|l|l|}
\hline Pão-de-Açúcar & Petrobrás \\
\hline Mensagem da Administração e Perfil do Relatório de & Mensagem do Presidente \\
Sustentabilidade & - A Petrobras \\
Mensagem do Presidente & Atuação integrada no Brasil e no exterior \\
Mensagem da Diretoria Executiva & Produção, receita e ações em alta \\
Perfil do Relatório & - Responsabilidade Social e Ambiental \\
Nível de Aplicação & Desafifi os de gestão em Responsabilidade Social \\
- Perfil do Grupo Pão de Açúcar & Relatório como instrumento de gestão \\
Missão, Visão e Pilares & - Direitos Humanos \\
Histórico, Estrutura Operacional e Apresentação & Princípio 1 - As empresas devem apoiar e respeitar a \\
Estrutura Multiformato & proteção dos direitos humanos reconhecidos \\
Distribuição de Lojas por Bandeira & internacionalmente \\
Marcas Exclusivas & Impactos nas comunidades \\
Estrutura Operacional e Organizacional & Investimentos sociais, culturais e esportivos \\
Política e Estratégia em Responsabilidade Social e e & Princípio 2- As empresas devem assegurar-se de que \\
Sustentabilidade Empresarial & não estejam sendo cúmplices de abusos e violações de \\
> Desempenho em Sustentabilidade & direitos humanos \\
\hline
\end{tabular}




\begin{tabular}{|c|c|}
\hline $\begin{array}{l}\text { Indicadores de Desempenho } \\
\text { Desempenho Econômico } \\
\text { Instituto Brasileiro de Análises Sociais (Ibase) } \\
\text { Desempenho Social } \\
\text { Relacionamento com Stakeholders } \\
\text { Nossa Gente } \\
\text { Clientes } \\
\text { Fornecedores } \\
\text { Sociedade } \\
\text { Programas Sociais } \\
\text { Desempenho Ambiental } \\
\text { Prêmios Recebidos no Período Coberto pelo Relatório } \\
\text { - Sumário GRI } \\
\text { - Créditos }\end{array}$ & $\begin{array}{l}\text { Relacionamento com os fornecedores } \\
\text { Estudo de Caso - Direitos Humanos } \\
\text { - Trabalho } \\
\text { Força de trabalho } \\
\text { Segurança, saúde e qualidade de vida } \\
\text { Remuneração e benefícios } \\
\text { Princípio } 3 \text { - As empresas devem apoiar a liberdade } \\
\text { de associação e o reconhecimento efetivo do direito à } \\
\text { negociação coletiva } \\
\text { Liberdade de associação } \\
\text { Princípio } 4 \text { - As empresas devem apoiar a eliminação } \\
\text { de todas as formas de trabalho forçado ou compulsório } \\
\text { Repúdio ao trabalho forçado } \\
\text { Princípio } 5 \text { - As empresas devem apoiar a erradicação } \\
\text { efetiva do trabalho infantil } \\
\text { Garantia dos direitos da criança e do adolescente } \\
\text { Princípio } 6 \text { - As empresas devem eliminar a } \\
\text { discriminação em relação ao empregado e ao cargo } \\
\text { Combate ao preconceito e à discriminação } \\
\text { Estudo de Caso - Trabalho } \\
\text { - Meio Ambiente } \\
\text { Princípio } 7 \text { - As empresas devem adotar uma } \\
\text { abordagem preventiva aos desafifi os ambientais } \\
\text { Atuação em Segurança, Meio Ambiente e Saúde } \\
\text { Mudanças do clima } \\
\text { Mapeamento, monitoração e redução de impactos } \\
\text { Princípio } 8 \text { - As empresas devem desenvolver } \\
\text { iniciativas para promover maior responsabilidade } \\
\text { ambiental } \\
\text { Consumo de energia, materiais e recursos naturais } \\
\text { Emissões, eflfl uentes e resíduos } \\
\text { Ecossistemas e biodiversidade } \\
\text { Produtos, conformidade e transporte } \\
\text { Conservação energética e consumo consciente } \\
\text { Princípio } 9 \text { - As empresas devem incentivar o } \\
\text { desenvolvimento e a difusão de tecnologias limpas que } \\
\text { não agridam o meio ambiente } \\
\text { Energias renováveis } \\
\text { Estudo de Caso - Meio Ambiente } \\
\text { Trebela Transparência } \\
\text { Relacionamento com as partes interessadas } \\
\text { Produtos e serviços } \\
\text { Princípio } 10-\text { As empresas devem comprometer-se } \\
\text { Pom o combate à corrupção em todas as suas formas } \\
\text { Andicadores }\end{array}$ \\
\hline
\end{tabular}




\begin{tabular}{|c|c|}
\hline Sabesp & Souza Cruz \\
\hline $\begin{array}{l}\text { Mensagem da Presidente do Conselho de } \\
\text { Administração } \\
\text { Mensagem do Presidente } \\
\text { A Sabesp } \\
\text { Painel de Indicadores } \\
\text { Gestão Empresarial } \\
\text { Governança Corporativa } \\
\text { Responsabilidade Social nos Relacionamentos } \\
\text { Indicadores de Desempenho Econômico-Financeiro } \\
\text { Indicadores de Desempenho Social } \\
\text { Investimento Social e Apoio Institucional } \\
\text { Gestão Ambiental } \\
\text { Parâmetros para O Relatório } \\
\text { Informações Corporativas }\end{array}$ & $\begin{array}{l}\text { - Mensagem Do Presidente } \\
\text { Busca da liderança baseada no compromisso com a } \\
\text { Sustentabilidade } \\
\text { - A Empresa } \\
\text { Perfil da Empresa } \\
\text { Impactos Econômicos das Atividades da Souza Cruz } \\
\text { A Souza Cruz e O Pacto Global } \\
\text { Visão Global } \\
\text { A Souza Cruz em Números } \\
\text { Governança Corporativa } \\
\text { Comitê de Responsabilidade Social } \\
\text { - Sobre Este Relatório } \\
\text { O Relatório Social 2007-2008 } \\
\text { - Desempenho Econômico } \\
\text { Quarto Ciclo de Diálogos } \\
\text { As Expectativas dos Participantes dos Diálogos e os } \\
\text { Compromissos Assumidos pela Souza Cruz } \\
\text { Histórico dos Diálogos } \\
\text { Ações Judiciais } \\
\text { Pronta para Ingressar no ISE } \\
\text { - Desempenho Ambiental } \\
\text { Quarto Ciclo de Diálogos } \\
\text { As Expectativas dos Participantes dos Diálogos e os } \\
\text { Compromissos Assumidos pela Souza Cruz } \\
\text { Histórico dos Diálogos } \\
\text { Economia Exemplar } \\
\text { Matriz Renovável } \\
\text { Grãos para a Sustentabilidade } \\
\text { - Desempenho Social } \\
\text { Quarto Ciclo de Diálogos } \\
\text { As Expectativas dos Participantes dos Diálogos e os } \\
\text { Compromissos Assumidos pela Souza Cruz } \\
\text { Histórico dos Diálogos } \\
\text { Investindo em Recursos Humanos } \\
\text { Voluntários Souza Cruz } \\
\text { Frota e Computador Social } \\
\text { Mais Apoio as Escolas do Campo } \\
\text { Do Meio Ambiente ao Desenvolvimento Comunitário } \\
\text { Formando Jovens para o Futuro } \\
\text { Engajamento com a Comunidade Científica } \\
\text { Varejo do Futuro } \\
\text { - Anexos } \\
\text { Parecer dos Verificadores } \\
\text { Os Participantes dos Diálogos } \\
\text { Indicadores do Global Reporting Initiative } \\
\text { Energia } \\
\text { Materiais } \\
\text { Água } \\
\text { Emissões, Efluentes e Resíduos } \\
\text { Transporte } \\
\text { Fornecedores } \\
\text { Produtos e Serviços } \\
\text { Uso da Terra/Biodiversidade } \\
\text { Legislação Social e Ambiental - Conformidade } \\
\text { Balanço Social Anual/2007 } \\
\text { Projetos Socioambientais da Souza Cruz } \\
\text { Educação } \\
\text { Meio Ambiente e Biodiversidade } \\
\text { Desenvolvimento Local Sustentável } \\
\text { a }\end{array}$ \\
\hline
\end{tabular}




\begin{tabular}{|l|l|}
\hline & Instituto Souza Cruz \\
& Investimentos Sociais da Souza Cruz de Acordo com \\
os Critérios do London Benchmarking Group (Lbg) & Computadores e Veículos doados pela Souza Cruz em \\
& 2007 \\
& Patrocínios e Doações Realizados pela Souza Cruz \\
& Sua Opinião \\
& \\
\hline
\end{tabular}

\begin{tabular}{|c|c|c|}
\hline Tenaris Confab & Vale & Whirlpool \\
\hline $\begin{array}{l}\text { Perfil da Companhia } \\
\text { Highlights } \\
\text { Mensagem aos Acionistas } \\
\text { Relatório da Administração } \\
\text { Informações Relevantes } \\
\text { Tubos } \\
\text { Equipamentos } \\
\text { Relatório de Ação Social } \\
\text { Conselho de Administração } \\
\text { Demonstrações Financeiras } \\
\text { Demonstração do Fluxo de Caixa }\end{array}$ & $\begin{array}{l}\text { Mensagemdo Conselho de } \\
\text { Administração } \\
\text { Mensagemdo Presidente } \\
\text { Introdução } \\
\text { Perfil } \\
\text { Desempenho dos Negócios } \\
\text { Governança, Ética e Transparência } \\
\text { Estratégia de Sustentabilidade } \\
\text { - Case:Transformação necessária } \\
\text { Gestão de Riscos e Sustentabilidade } \\
\text { Pessoas } \\
\text { - Saúde e Segurança } \\
\text { - Emprego e Desenvolvimento de } \\
\text { Pessoas } \\
\text { - Case: Patrimônio Valioso } \\
\text { Direitos Humanos } \\
\text { - Case:A luta pelo trabalho decente } \\
\text { Meio Ambiente } \\
\text { - Dispêndios Ambientais } \\
\text { Conformidade } \\
\text { - Case: Floresta protege floresta } \\
\text { - Produção } \\
\text { - Biodiversidade } \\
\text { - Case:Atitude Ambiental } \\
\text { - Energia } \\
\text { - Mudanças Climáticas } \\
\text { - Case: É Powerplay! } \\
\text { Desenvolvimento Territorial } \\
\text { - Case:Conversando a gente se } \\
\text { entende } \\
\text { - Investimentos Sociais } \\
\text { - Fundação Vale } \\
\text { - Contratação Local } \\
\text { - Incidentes: prevenir e solucionar } \\
\text { - Comunidades Tradicionais } \\
\text { - Práticas de Reassentamento } \\
\text { Involuntário } \\
\text { - Case:No ninho dos Gaviões } \\
\text { Cadeia de Valor } \\
\text { - Nossos Fornecedores } \\
\text { - Case: Efeito emcascata }\end{array}$ & $\begin{array}{l}\text { Mensagem do Presidente } \\
\text { Visão de Sustentabilidade } \\
\text { Valores e Princípios Éticos } \\
\text { Governanças Corporativa } \\
\text { Inovação } \\
\text { Nossos Relacionamentos } \\
\text { Nosso Desempenho } \\
\text { Sobre o Relatório } \\
\text { Índice Remissivo GRI e TNS } \\
\text { Parecer da Auditotia } \\
\text { Informações Corporativas e } \\
\text { Créditos }\end{array}$ \\
\hline
\end{tabular}




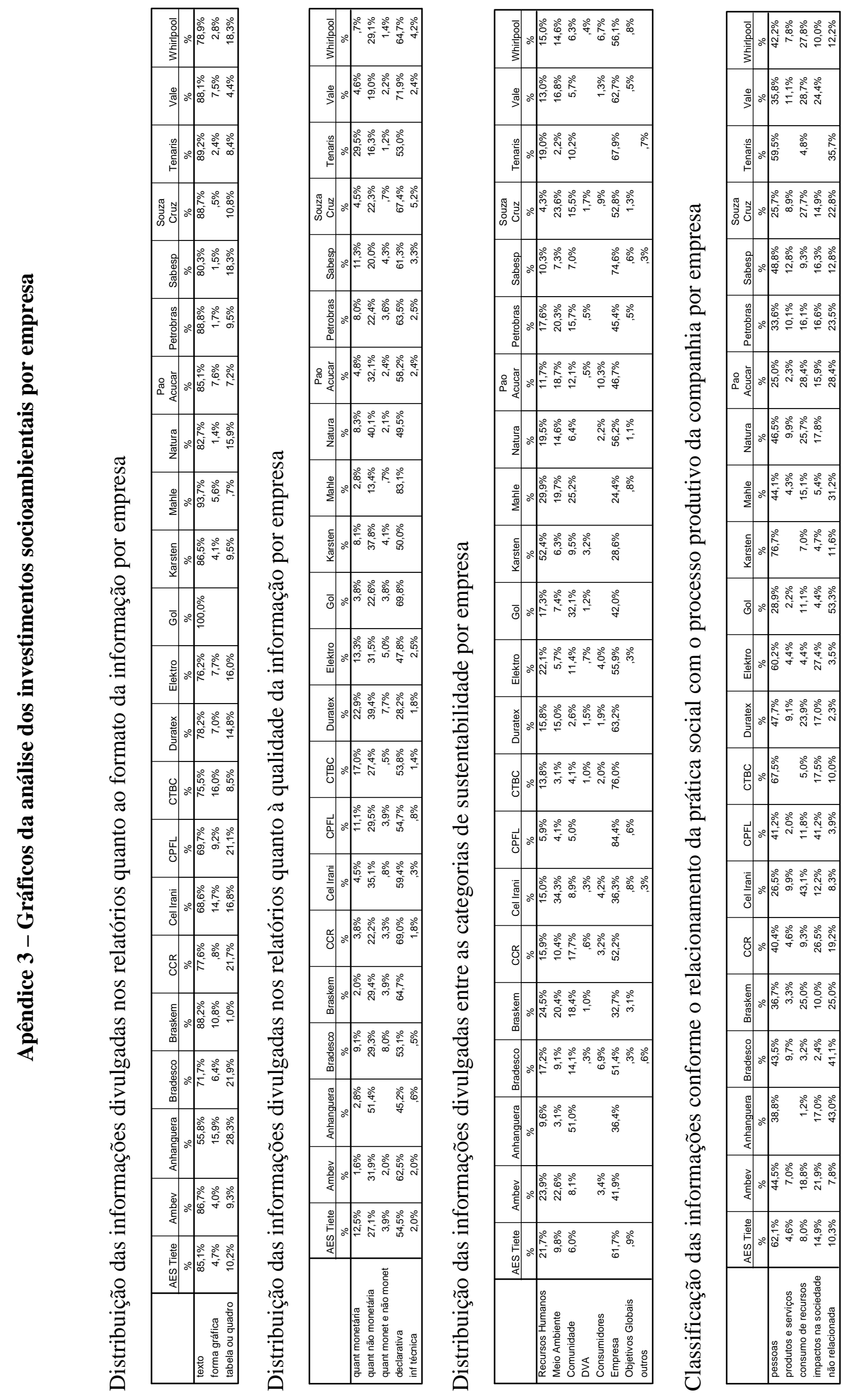



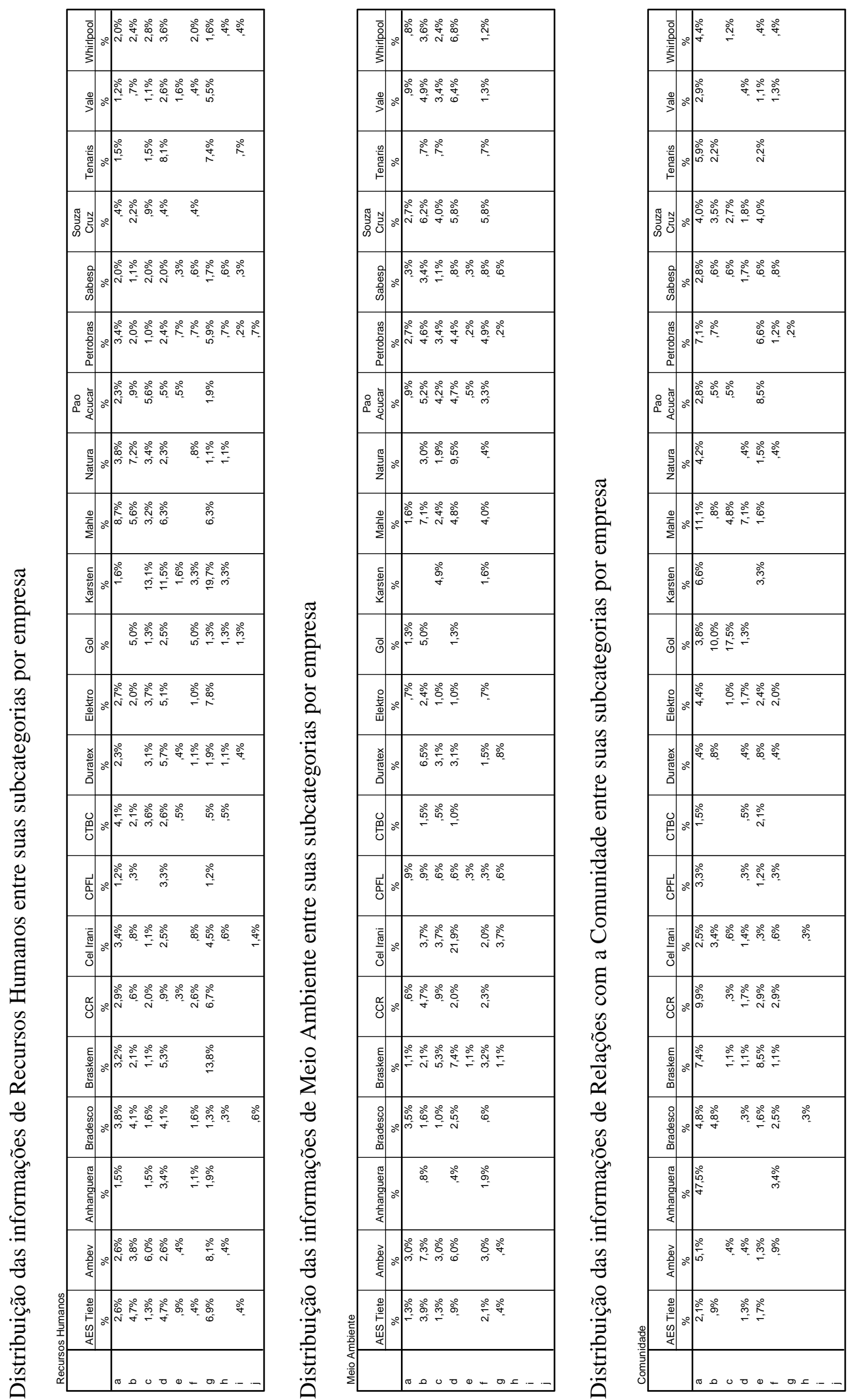

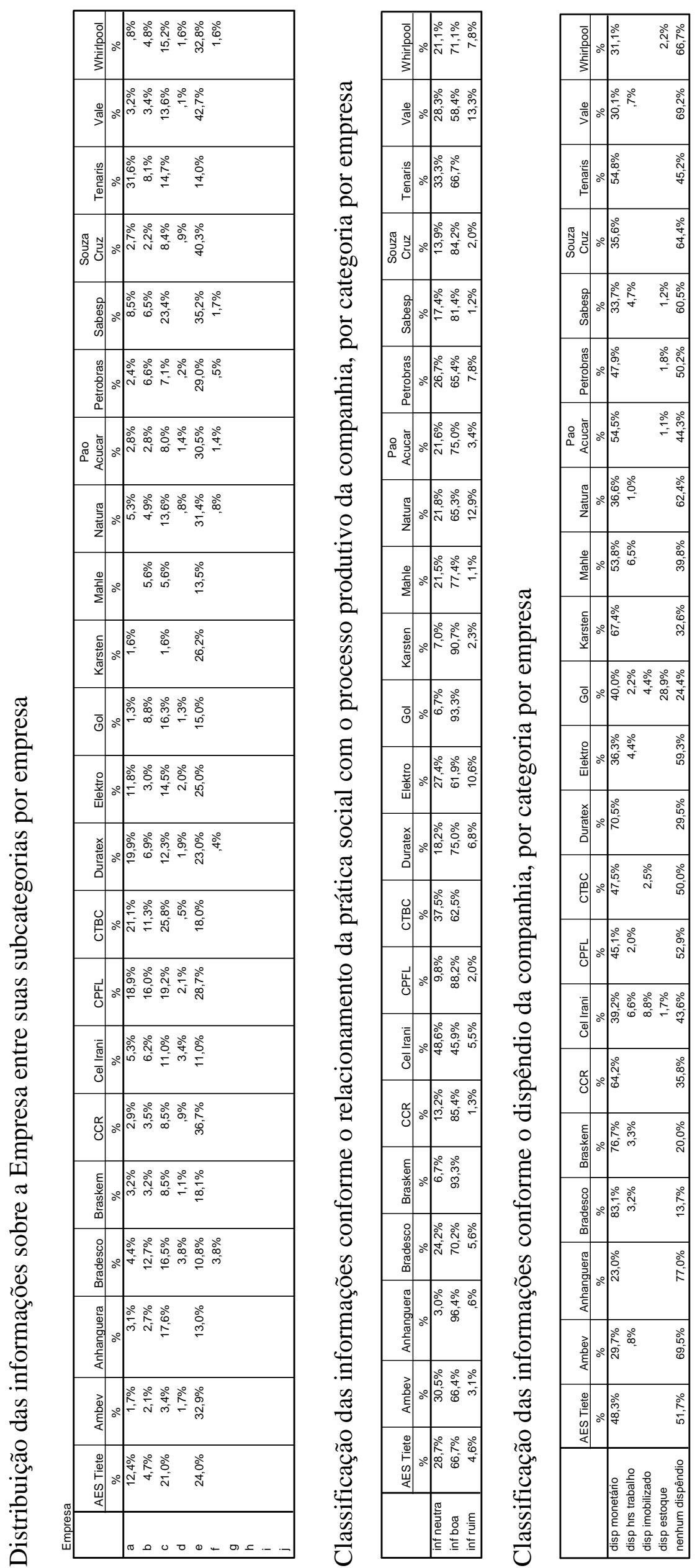

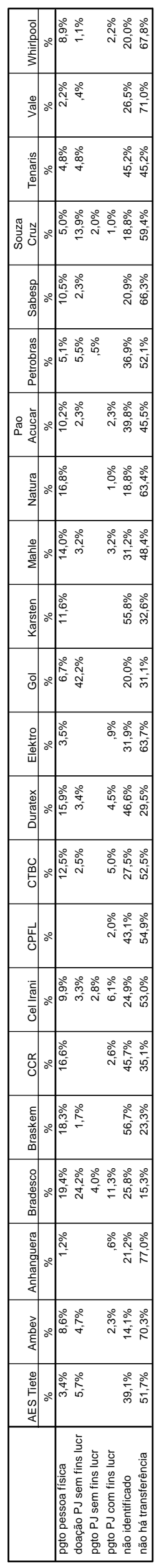




\section{Apêndice 4 - Roteiro de Entrevista para Validação da Tipologia de Investimentos Socioambientais}

\section{$\underline{\text { Roteiro de Entrevista - Validacão da tipologia de investimentos socioambientais }}$}

\section{Entrevistadas: Profa. Anna Maria T. Medeiros Peliano}

Profa. Dra. Maísa de Souza Ribeiro

I. Apresentação da Pesquisa

a) Apresentar DVA Votorantin Celulose e Papel S.A. (Anexo H)

b) Apresentar DVA Aracruz Celulose S.A. (Anexo I)

c) Problema de pesquisa: identificar em quais condições as empresas podem considerar seus investimentos sociais como distribuição de valor adicionado.

d) Explicar metodologia da pesquisa

i. Pesquisa realizada com 22 empresas de capital aberto

ii. Análise de conteúdo dos Relatórios de Sustentabilidade

iii. Categorização de todas as informações fornecidas no Relatório conforme tabela em anexo. (Apêndice 6)

iv. Reavaliação das categorias após análise dos relatórios

v. Estrutura de investimentos a ser analisada

e) Objetivo da entrevista: validação da tipologia de investimentos socioambientais.

II. Entrevista

1. Qual a intenção das empresas quando desenvolvem ações de responsabilidade social?

2. As categorias 1 e 4 (Recursos Humanos e Empresa) dizem respeito apenas a investimentos com interesse maior para a empresa que para a comunidade. A senhora concorda?

3. A categoria 2, Meio Ambiente, apresenta na parte A todas as categorias possíveis de investimentos da empresa nessa área? 
4. A parte B da categoria 2 esgota as possibilidades quanto ao dispêndio realizado pela empresa na efetivação do investimento ambiental?

5. A parte $\mathrm{C}$ da categoria 2 esgota as possibilidades quanto ao meio de realização do investimento ambiental?

6. A categoria 3, Comunidade, apresenta na parte A todas as categorias possíveis de investimentos da empresa nessa área?

7. A parte B da categoria 3 esgota as possibilidades quanto ao dispêndio realizado pela empresa na efetivação do investimento social na comunidade?

8. A parte $\mathrm{C}$ da categoria 3 esgota as possibilidades quanto ao meio de realização do investimento social na comunidade?

9. As informações coletadas nas partes B e C são fundamentais para a análise dos investimentos socioambientais realizados pela empresa, na sua opinião? Por quê?

10. As subcategorias adotadas na parte A de Comunidade e Meio Ambiente são excludentes?

11. O apelo do investimento social (crianças, idosos, deficientes...) é uma informação imprescindível para avaliar se o investimento social adiciona valor para a sociedade? 


\section{Apêndice 5 - Roteiro de Entrevista para Validação dos Resultados}

\section{$\underline{\text { Roteiro de Entrevista - Validacão dos resultados }}$}

Entrevistado: Prof. Dr. Roberto Luís Olinto Ramos

I. Apresentação da Pesquisa

f) Apresentar DVA Votorantin Celulose e Papel S.A. (Anexo H)

g) Apresentar DVA Aracruz Celulose S.A. (Anexo I)

h) Problema de pesquisa: identificar em quais condições as empresas podem considerar seus investimentos sociais como distribuição de valor adicionado.

i) Metodologia da pesquisa

II. Entrevista

1. O PIB brasileiro mensura ações de responsabilidade social empresarial? Como?

a) Quando o investimento é realizado por meio de doação para pessoa física?

b) Quando o investimento é realizado por meio de doação para pessoa jurídica sem fins de lucro?

c) Quando o investimento é realizado por meio de doação de um serviço adquirido de PJ com ou sem fins de lucro?

d) Quando o investimento é realizado por meio de doação de horas de trabalho dos empregados?

e) Quando o investimento usa incentivos fiscais como a Lei Rouanet?

f) Quando ocorre campanha para arrecadação e transferência de recursos?

2. Doações em dinheiro, estoques ou bens do imobilizado têm tratamento diferenciado no PIB?

3. O senhor concorda que quando a empresa realiza investimentos sociais ela está promovendo uma redistribuição de remuneração entre os fatores de produção?

4. O PIB brasileiro já incluiu algum efeito do desgaste do meio ambiente?

5. Se incluísse, seria classificado como consumo intermediário ou distribuição de valor adicionado?

6. Investimentos em meio ambiente, realizados pelas empresas, poderiam ser caracterizados como distribuição de valor adicionado? 


\section{Apêndice 6 - Tipologia usada nas entrevistas de validação do estudo empírico}

parte A

\begin{tabular}{|c|c|c|}
\hline & \multirow{11}{*}{ Recursos Humanos } & Dados sobre quantidades de empregados [inclusive por diferentes idades, raças e gêneros] \\
\hline & & Avaliação de desempenho e ambiente de trabalho \\
\hline & & $\begin{array}{l}\text { c. Prêmios, benefícios, incentivos, planos de carreira e políticas salariais [exceto participação nos lucros } \\
\text { e prêmios em ações] }\end{array}$ \\
\hline & & $\begin{array}{l}\text { d. Treinamentos e cursos de capacitação para empregados [exceto em temas relacionados ao meio } \\
\text { ambiente, saúde e segurança no trabalho] }\end{array}$ \\
\hline & & Previdência dos empregados \\
\hline & & Emprego de minorias e/ou deficientes \\
\hline & & Saúde e segurança no trabalho [inclui treinamentos em temas de meio ambiente] \\
\hline & & $\begin{array}{l}\text { h. Engajamento dos empregados nas decisões da empresa [ações que incentivem a participação de } \\
\text { empregados nos processo decisórios e/ou informem os empregados sobre as decisões da empresa] }\end{array}$ \\
\hline & & $\begin{array}{l}\text { i. Participação nos lucros, prêmios em ações ou opções de compra de ações da empresa, incentivos para } \\
\text { compra de ações }\end{array}$ \\
\hline & & Direitos do trabalhador, Direitos Humanos e Trabalho Infantil \\
\hline & & Informações de conjuntura com seus impactos nos empregados da empresa. \\
\hline & \multirow{6}{*}{ Comunidade } & $\begin{array}{l}\text { a. } \quad \text { Realização de projetos sociais na comunidade [quando a participação efetiva da empresa for evidente] } \\
\begin{array}{l}\text { b. } \\
\text { empresa] }\end{array}\end{array}$ \\
\hline 2. & & c. Doações para projetos sociais do governo [quando não há em troca a divulgação da marca da empresa] \\
\hline & & $\begin{array}{l}\text { d. Voluntariado empresarial quando o apoio da empresa envolver algum tipo de investimento [por } \\
\text { exemplo, em horas de trabalho] }\end{array}$ \\
\hline & & Patrocínios a escolas, artes e esportes [quando há em troca a divulgação da marca da empresa] \\
\hline & & Parcerias público-privadas quando o beneficiário for a comunidade \\
\hline & & g. Doações para campanhas políticas \\
\hline \multirow{7}{*}{3.} & \multirow{7}{*}{ Meio Ambiente } & $\begin{array}{l}\text { a. Realização de projetos ambientais em parceria com outras instituições, públicas ou privadas [quando } \\
\text { for evidente que não há vínculo da atividade econômica da empresa com o projeto realizado] }\end{array}$ \\
\hline & & $\begin{array}{l}\text { b. Políticas Ambientais da empresa [inclui informações de conjuntura com seus impactos nas decisões } \\
\text { tomadas pela empresa] }\end{array}$ \\
\hline & & $\begin{array}{l}\text { c. Sistemas de Gerenciamento Ambiental [procedimentos incluídos no processo operacional da empresa } \\
\text { com o objetivo de melhorar sua relação com o meio ambiente] }\end{array}$ \\
\hline & & d. Impacto dos produtos e processos [inclui uso da água e energia e passivos ambientais] \\
\hline & & $\begin{array}{l}\text { e. Investimentos em ativos ambientais [considerar ativo ambiental os bens e direitos que tenham } \\
\text { capacidade de geração de benefício econômico em períodos futuros e que visem à preservação, proteção e } \\
\text { recuperação ambiental (RIBEIRO, 2006, p. 61)] }\end{array}$ \\
\hline & & $\begin{array}{l}\text { f. Educação, Pesquisa e Treinamento [exceto para empregados da empresa; quando for evidente a relação } \\
\text { do tema com a atividade econômica da empresa] }\end{array}$ \\
\hline & & \begin{tabular}{|l} 
g. $\quad$ Mercado de Créditos de Carbono \\
\end{tabular} \\
\hline & \multirow{12}{*}{ Empresa } & Desempenho Financeiro \\
\hline & & $\begin{array}{l}\text { b. Desempenho Mercadológico [informações sobre crescimento da empresa, participação de mercado, } \\
\text { campanhas publicitárias etc.] }\end{array}$ \\
\hline & & $\begin{array}{l}\text { c. Processo operacional [quando a informação refere-se aos produtos ou ao processo de produção da } \\
\text { empresa em sua operação principal - considerar informações de empregados e meio ambiente nos tópicos } \\
\text { anteriores] }\end{array}$ \\
\hline & & $\begin{array}{l}\text { d. Desempenho Sócio-ambiental [apenas quando a empresa declara prêmios recebidos pela atuação sócio- } \\
\text { ambiental da empresa como um todo] }\end{array}$ \\
\hline & & $\begin{array}{l}\text { e. Políticas, valores e estratégias da empresa [quando relacionada apenas à operação da empresa e seu } \\
\text { contexto - não envolvem políticas e valores com empregados, meio ambiente ou ações com a comunidade] }\end{array}$ \\
\hline & & Desenvolvimento ou venda de produtos com forte apelo sócio-ambiental \\
\hline & & $\begin{array}{l}\text { g. Adoção de objetivos globais de sustentabilidade [declarações de anuência a políticas nacionais ou } \\
\text { globais - não desenvolvidas pela empresa - como: Objetivos do Milênio, Princípios do Equador, Pacto } \\
\text { Global etc.] }\end{array}$ \\
\hline & & Estrutura de governança corporativa e relações com acionistas \\
\hline & & Segurança do produto e para o consumidor \\
\hline & & Serviços de atendimento ao consumidor \\
\hline & & Atendimento especial para consumidores deficientes e idosos \\
\hline & & Relação com Fornecedores [inclui treinamentos, brindes e incentivos para fo \\
\hline
\end{tabular}


parte B

parte C

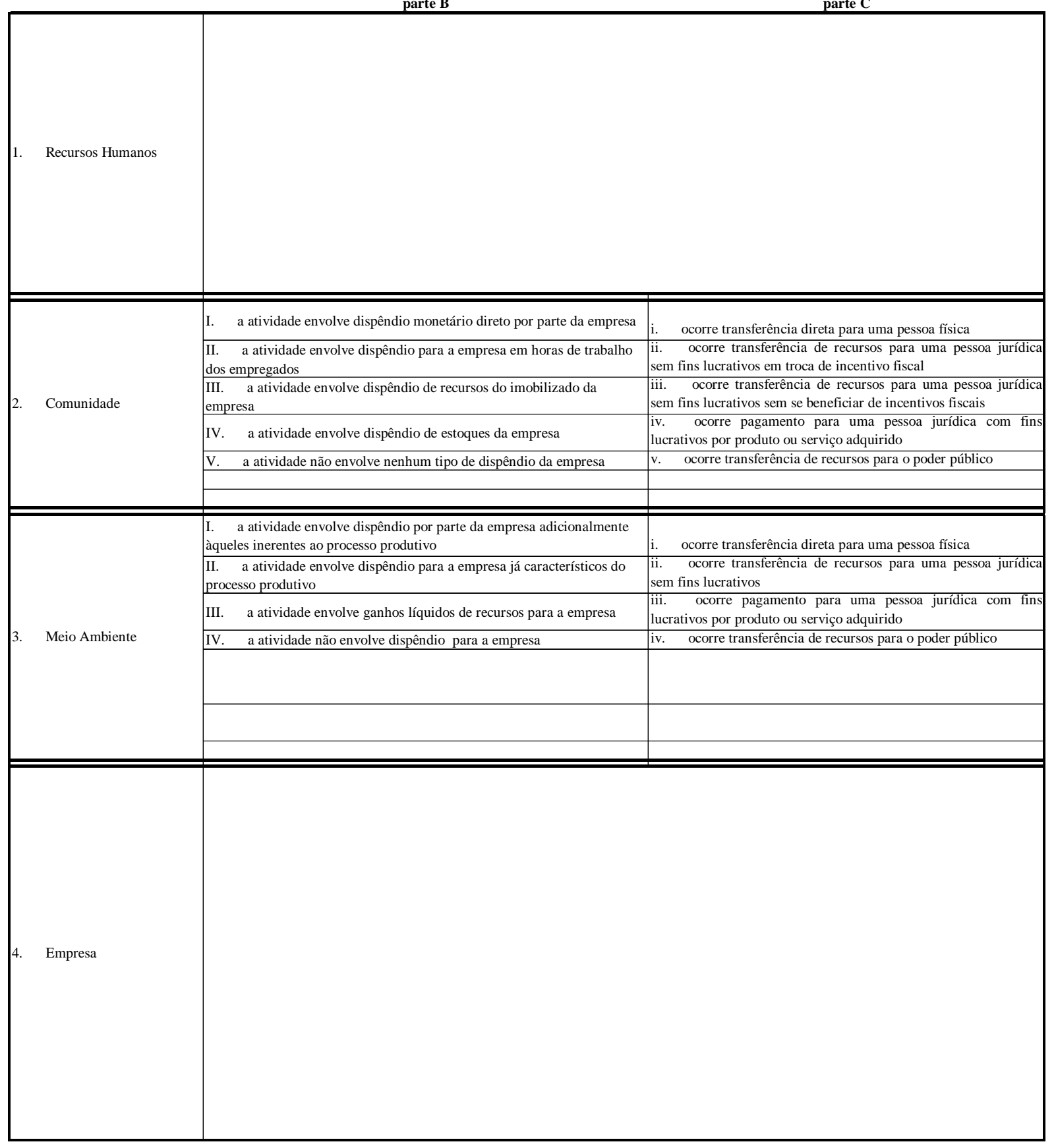





\author{
ANEXOS \\ Anexo A - DVAs com distribuição de valor adicionado para comunidade \\ Anexo B - Tabela original de Garriga e Melé (2004, p. 63-64) e referências citadas pelos \\ autores na tabela \\ Anexo C - Tabela original de Freeman e Reed (1983, p. 94) \\ Anexo D - Modelo Ibase de Balanço Social para empresas em geral \\ Anexo E - Modelo de DVA do pronunciamento técnico CPC n. ${ }^{\circ}$ 09/2008 \\ Anexo F - Contas Econômicas Integradas 2006 (IBGE, 2008b) \\ Anexo G - Tabela de Recursos e Usos 2006 (IBGE, 2008b) \\ Anexo H - DVA da empresa Votarantim Celulose e Papel S.A. \\ Anexo I - DVA da empresa Aracruz Celulose S.A.
}


Anexo A - DVAs com distribuição de valor adicionado para comunidade

Demonstração do Valor Adicionado da empresa Unilever no Reino Unido

\begin{tabular}{|c|c|c|}
\hline Value added statement & $\mathrm{f} 000$ & \\
\hline Unilever UK turnover & $2,478,638$ & \\
\hline $\begin{array}{l}\text { Raw materials/packaging/finished goods } \\
\text { Advertising \& promotional expenses } \\
\text { Research \& Development costs } \\
\text { Other suppliers } \\
\text { Total bought in goods \& services }\end{array}$ & $\begin{array}{r}1,343,478 \\
297,900 \\
52,911 \\
99,600 \\
1,793,889\end{array}$ & \\
\hline Value added & 684,750 & \\
\hline Distribution of value added & & $\%$ of value added \\
\hline Government & 121,060 & 18 \\
\hline Employees & 315,309 & 46 \\
\hline Community & 9,005 & 1 \\
\hline Providers of capital \& reinvested in business & 239,376 & 35 \\
\hline Value distributed & 684,750 & 100 \\
\hline
\end{tabular}

FONTE: UNILEVER, 2006 (destaque da autora)

Demonstração do Valor Adicionado da empresa Cia de Bebidas Ipiranga no Brasil DEMONSTRAÇÃO DO VALOR ADICIONADO (DVA)

(valores expressos em milhares de reais)

\begin{tabular}{|c|c|}
\hline I- Geraçâo de Riqueza & 2006 \\
\hline Recelta Bruta & 583.563 \\
\hline Outras Receltas & 29.319 \\
\hline (-) Insumos e Serviços Adquiridos de Tercelras & (325.243) \\
\hline (-) Provisâo p/ Crédiltos de Liquidação Duvidosa & (884) \\
\hline (-) Depreclação, Amortização e Exaustão & (5.579) \\
\hline (t) Receltas Financeiras & 12.459 \\
\hline (+t-) Resultado da Equivalência Patrimonial & 14.398 \\
\hline Valor Adicionado a Distribuir & 308.033 \\
\hline \multicolumn{2}{|l|}{ II - Distribuiçđo por Stakeholders } \\
\hline \multicolumn{2}{|l|}{ Governo } \\
\hline Impostos $\theta$ Contribulçб̃es & 187.487 \\
\hline \multicolumn{2}{|l|}{ Colaboradores } \\
\hline Salários & 29.574 \\
\hline Encargos Previdenclários & 13.662 \\
\hline Beneficios & 11.361 \\
\hline Participação nos Resultados & 28 \\
\hline \multicolumn{2}{|l|}{ Financladores } \\
\hline Remuneração de capital de terceiros & 44.374 \\
\hline \multicolumn{2}{|l|}{ Acionistas } \\
\hline Lucros retidoe/ prejuizo do exercicio & 20.565 \\
\hline
\end{tabular}

FONTE: CIA DE BEBIDAS IPIRANDA, 2006, p. 31 (destaque da autora) 
Demonstração do Valor Adicionado da empresa Singapore Press Holdings em

\section{Singapura}

\section{VALUE ADDED}

STATEMENT

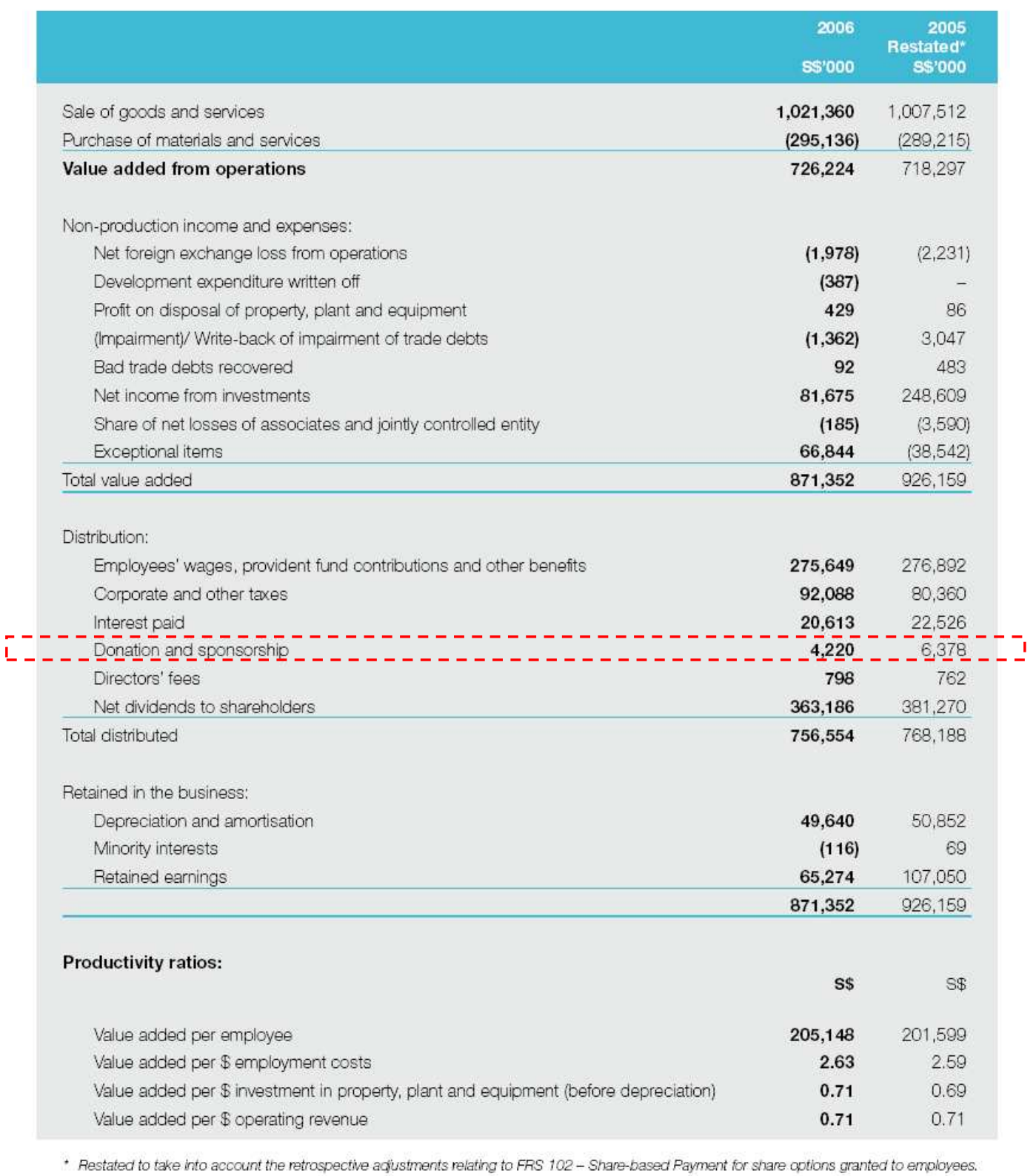

FONTE: SINGAPORE PRESS HOLDINGS, 2006 (destaque da autora) 


\section{Anexo B - Tabela original de Garriga e Melé (2004, p. 63-64) e referências citadas pelos}

\section{autores na tabela}

\begin{tabular}{|c|c|c|c|}
\hline Types of theory & Approaches & Short description & Some key references \\
\hline \multirow{5}{*}{$\begin{array}{l}\text { Instrumental theories } \\
\text { (focusing on achieving economic } \\
\text { objectives through social activities) }\end{array}$} & Maximization of shareholder value & Long-term value maximization & Friedman $(1970)$, Jensen $(2000)$ \\
\hline & $\begin{array}{l}\text { Strategies for competitive advan- } \\
\text { tages }\end{array}$ & $\begin{array}{l}\text { - Social investments in a competi- } \\
\text { tive context }\end{array}$ & Porter and Kramer (2002) \\
\hline & & $\begin{array}{l}\text { - Strategies based on the natural } \\
\text { resource view of the firm and the } \\
\text { dynamic capabilities of the firm }\end{array}$ & Hart (1995), Lizt (1996) \\
\hline & & $\begin{array}{l}\text { - Strategies for the bottom of the } \\
\text { economic pyramid }\end{array}$ & $\begin{array}{l}\text { Prahalad and Hammond (2002), } \\
\text { Hart and Christensen (2002), } \\
\text { Prahalad (2003) }\end{array}$ \\
\hline & Cause-related marketing & $\begin{array}{l}\text { Altruistic activities socially recog- } \\
\text { nized used as an instrument of } \\
\text { marketing }\end{array}$ & $\begin{array}{l}\text { Varadarajan and Menon (1988), } \\
\text { Murray and Montanari (1986) }\end{array}$ \\
\hline \multirow{3}{*}{$\begin{array}{l}\text { Political theories } \\
\text { (focusing on a responsible } \\
\text { use of business power } \\
\text { in the political arena) }\end{array}$} & Corporate constitutionalism & $\begin{array}{l}\text { Social responsibilities of businesses } \\
\text { arise from the amount of social } \\
\text { power that they have }\end{array}$ & Davis $(1960,1967)$ \\
\hline & Integrative Social Contract Theory & $\begin{array}{l}\text { Assumes that a social contract be- } \\
\text { tween business and society exists }\end{array}$ & $\begin{array}{l}\text { Donaldson and Dunfee (1994, } \\
\text { 1999) }\end{array}$ \\
\hline & Corporate (or business) citizenship & $\begin{array}{l}\text { The firm is understood as being like } \\
\text { a citizen with certain involvement } \\
\text { in the community }\end{array}$ & $\begin{array}{l}\text { Wood and Lodgson (2002), Andriof } \\
\text { and McIntosh (2001) Matten and } \\
\text { Crane (in press) }\end{array}$ \\
\hline \multirow[t]{4}{*}{$\begin{array}{l}\text { Integrative theories } \\
\text { (focusing on the integration of } \\
\text { social demands) }\end{array}$} & Issues management & $\begin{array}{l}\text { Corporate processes of response to } \\
\text { those social and political issues } \\
\text { which may impact significantly } \\
\text { upon it }\end{array}$ & $\begin{array}{l}\text { Sethi (1975), Ackerman (1973), } \\
\text { Jones (1980), Vogel, (1986), } \\
\text { Wartick and Mahon (1994) }\end{array}$ \\
\hline & Public responsibility & $\begin{array}{l}\text { Law and the existing public policy } \\
\text { process are taken as a reference for } \\
\text { social performance }\end{array}$ & Preston and Post $(1975,1981)$ \\
\hline & Stakeholder management & $\begin{array}{l}\text { Balances the interests of the stake- } \\
\text { holders of the firm }\end{array}$ & $\begin{array}{l}\text { Mitchell et al. (1997), Agle and } \\
\text { Mitchell (1999), Rowley (1997) }\end{array}$ \\
\hline & Corporate social performance & $\begin{array}{l}\text { Searches for social legitimacy and } \\
\text { processes to give appropriate re- } \\
\text { sponses to social issues }\end{array}$ & $\begin{array}{l}\text { Carroll (1979), Wartick and } \\
\text { Cochran (1985), Wood (1991b) } \\
\text { Swanson (1995) }\end{array}$ \\
\hline \multirow[t]{4}{*}{$\begin{array}{l}\text { Ethical theories } \\
\text { (focusing on the right thing to } \\
\text { achieve a good society }\end{array}$} & Stakeholder normative theory & $\begin{array}{l}\text { Considers fiduciary duties towards } \\
\text { stakeholders of the firm. Its applica- } \\
\text { tion requires reference to some } \\
\text { moral theory (Kantian, Utilitarian- } \\
\text { ism, theories of justice, etc.) }\end{array}$ & $\begin{array}{l}\text { Freeman (1984, 1994), Evan and } \\
\text { Freeman (1988), Donaldson and } \\
\text { Preston (1995), Freeman and Phil- } \\
\text { lips (2002), Phillips et al. (2003) }\end{array}$ \\
\hline & Universal rights & $\begin{array}{l}\text { Frameworks based on human rights, } \\
\text { labor rights and respect for the en- } \\
\text { vironment }\end{array}$ & $\begin{array}{l}\text { The Global Sullivan Principles } \\
\text { (1999), UN Global Compact (1999) }\end{array}$ \\
\hline & Sustainable development & $\begin{array}{l}\text { Aimed at achieving human devel- } \\
\text { opment considering present and } \\
\text { future generations }\end{array}$ & $\begin{array}{l}\text { World Commission on Environ- } \\
\text { ment and Development (Brutland } \\
\text { Report) (1987), Gladwin and Ken- } \\
\text { nelly (1995) }\end{array}$ \\
\hline & The common good & $\begin{array}{l}\text { Oriented towards the common } \\
\text { good of society }\end{array}$ & $\begin{array}{l}\text { Alford and Naughton (2002), Melé } \\
\text { (2002) Kaku (1997) }\end{array}$ \\
\hline
\end{tabular}




\section{Referências}

Ackerman, R. W.: 1973, 'How Companies Respond to Social Demands', Harvard University Review 51(4), 88-98.

Agle, B. R. and R. K. Mitchell: 1999, 'Who Matters to CEOs? An Investigation of Stakeholder Attributes and Salience, Corporate Performance and CEO Values', Academy of Management Journal 42(5), 507- 526.

Alford, H. and M. Naugthon: 2002, 'Beyond the Shareholder Model of the Firm: Working toward the Common Good of a Business', in S. A. Cortright and M. Naugthon (eds.), Rethinking the Purpose of Business. Interdisciplinary Essays from the Catholic Social Tradition (Notre Dame University Press,Notre Dame), pp. 27-47.

Andriof, J. and M. McIntosh (eds.): 2001, Perspectives on Corporate Citizenship (Greenleaf, Sheffield, UK).

Carroll, A. B.: 1979, 'A Three-Dimensional Conceptual Model of Corporate Performance', Academy of Management Review 4(4), 497-505.

Davis, K.: 1960, 'Can Business Afford to Ignore Corporate Social Responsibilities?', California Management Review 2, 70-76.

Davis, K.: 1967, 'Understanding The Social Responsibility Puzzle', Business Horizons 10(4), $45-51$.

Donaldson, T. and T. W. Dunfee: 1994, 'Towards a Unified Conception of Business Ethics: Integrative Social Contracts Theory’, Academy of Management Review 19, 252-284.

Donaldson, T. and T. W. Dunfee: 1999, Ties That Bind: A Social Contracts Approach to Business Ethics (Harvard Business School Press, Boston).

Donaldson, T. and L. E. Preston: 1995, 'The Stakeholder Theory of the Corporation: Concepts, Evidence, and Implications', Academy of Management Review 20(1), 65-91.

Evan, W. M. and R. E. Freeman: 1988, 'A Stakeholder Theory of the Modern Corporation: Kantian Capitalism', in T. Beauchamp and N. Bowie (eds.), Ethical Theory and Business (Prentice Hall, Englewood Cliffs), pp. 75-93.

Freeman, R. E.: 1984, Strategic Management: A Stakeholder Approach (Pitman, Boston).

Freeman, R. E.: 1994, 'The Politics of Stakeholder Theory: Some Future Directions', Business Ethics Quarterly 4(4), 409-429.

Freeman, R. E. and R. A. Philips: 2002, 'Stakeholder Theory: A Libertarian Defence', Business Ethics Quarterly 12(3), 331-349.

Friedman, M.: 1970, 'The Social Responsibility of Business is to Increase its Profits', New York Times. 
Gladwin, T. N. and J. J. Kennelly: 1995, 'Shifting Paradigms for Sustainable Development: Implications for Management Theory and Research.' Academy of Management Review 20(4), 874-904.

Global Sullivan Principles, The: 1999, http://globalsullivanprinciples.org (September 2003).

Hart, S. L.: 1995, 'A Natural-Resource-Based View of the Firm', Academy of Management Review 20(4), 986-1012.

Hart, S. L. and C. M. Christensen: 2002, 'The Great Leap. Driving Innovation from the Base of the Pyramid', MIT Sloan Management Review 44(1), 51-57. Magazine, September 13th, 32-33, 122, 126.

Jensen, M. C.: 2000, 'Value Maximization, Stakeholder Theory, and the Corporate Objective Function', in M. Beer and N. Nohria (eds.), Breaking the Code of Change (Harvard Business School Press, Boston), pp. 37-58. Reprinted (2002) as 'Value Maximization, Stakeholder Theory, and the Corporate Objective Function', Business Ethics Quarterly 12(2), 235-256.

Jones, T. M.: 1980, 'Corporate Social Responsibility Revisited, Redefined', California Management Review 22(2), 59-67.

Kaku, R.: 1997, 'The Path of Kyosei’, Harvard Business Review 75(4), 55-62.

Litz, R. A.: 1996, 'A Resourced-Based-View of the Socially Responsible Firm: Stakeholder Interdependence, Ethical Awareness, and Issue Responsiveness as Strategic Assets', Journal of Business Ethics 15, 1355- 1363.

Matten, D. and A. Crane: in press, 'Corporate Citizenship: Towards an Extended Theoretical Conceptualization', Academy of Management Review.

Mele, D.: 2002, Not only Stakeholder Interests. The Firm Oriented toward the Common Good (University of Notre Dame Press, Notre Dame).

Mitchell, R. K., B. R. Agle and D. J. Wood: 1997, 'Toward a Theory of Stakeholder Identification and Salience: Defining the Principle of Who and What Really Counts', Academy of Management Review 22(4), 853-886.

Murray, K. B. and J. R. Montanari: 1986, 'Strategic Management of the Socially Responsible Firm: Integrating Management and Marketing Theory', Academy of Management Review 11(4), 815-828.

Phillips, R. A., E. Freeman and A. C. Wicks: 2003, 'What Stakeholder Theory Is Not', Business Ethics Quarterly 13(1), 479-502.

Porter, M. E. and M. R. Kramer: 2002, 'The Competitive Advantage of Corporate Philanthropy', Harvard Business Review 80(12), 56-69.

Prahalad, C. K.: 2002, 'Strategies for the Bottom of the Economic Pyramid: India as a Source of Innovation', Reflections: The SOL Journal 3(4), 6-18.

Prahalad, C. K. and A. Hammond: 2002, 'Serving the World's Poor, Profitably', Harvard Business Review 80(9), 48-58. 
Preston, L. E. and J. E. Post: 1975, Private Management and Public Policy. The Principle of Public Responsibility (Prentice Hall, Englewood Cliffs, NJ).

Preston, L. E. and J. E. Post: 1981, 'Private Management and Public Policy', California Management Review 23(3), 56-63.

Rowley, T. J.: 1997, 'Moving Beyond Dyadic Ties: A Network Theory of Stakeholder Influences', Academy of Management Review 22(4), 887-911.

Sethi, S. P.: 1975, 'Dimensions of Corporate Social Performance: An Analytical Framework', Califórnia Management Review 17(3), 58-65.

Swanson, D. L.: 1995, 'Addressing a Theoretical Problem by Reorienting the Corporate Social Performance Model', Academy of Management Review 20(1), 43- 64.

United Nations: 1999, Global Compact (www.unglobalcompact.org).

Varadarajan, P. R. and A. Menon: 1988, 'Cause-Related Marketing: A Coalignment of Marketing Strategy and Corporate Philanthropy', Journal of Marketing 52(3), 58-58.

Vogel, D.: 1986, 'The Study of Social Issues in Management: A Critical Appraisal', California Management Review 28(2), 142-152.

Wartick, S. and P. L. Cochran: 1985, 'The Evolution of Corporate Social Performance Model', Academy of Management Review 10(4), 758-769.

Wartick and Mahon: 1994: 'Towards a Substantive Definition of the Corporate Issue Construct: A Review and Synthesis of Literature', Business and Society 33(3), 293-311.

Wood, D. J.: 1991b, 'Corporate Social Performance Revisited', Academy of Management Review 16(4), 691- 718.

Wood, D. J. and J. M. Lodgson: 2002, 'Business Citizenship: From Individuals to Organizations’, Business Ethics Quarterly, Ruffin Series, No. 3, 59-94.

World Commission on Environment and Development: 1987, Our Common Future (Oxford University Press, Oxford). 
Anexo C - Tabela original de Freeman e Reed (1983, p. 94)

\begin{tabular}{|c|c|c|c|}
\hline \multirow{2}{*}{$\begin{array}{c}\text { Power Stake } \\
\text { Equity }\end{array}$} & \multirow{2}{*}{$\begin{array}{l}\text { f'ormal or Voting } \\
\text { - Stockholders } \\
\text { - Directors } \\
\text { - Minority interesis }\end{array}$} & \multirow[t]{2}{*}{ Economilc } & \multirow{2}{*}{$\begin{array}{l}\text { Political } \\
\text { - Dissident } \\
\text { stockholders }\end{array}$} \\
\hline & & & \\
\hline Economlc & 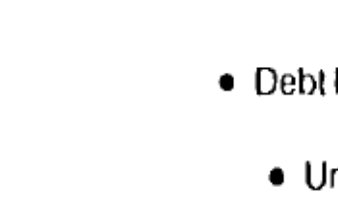 & $\begin{array}{l}\text { - Supplers } \\
\text { olders } \\
\text { - Customers } \\
\text { ons }\end{array}$ & $\begin{array}{l}\text { - Local governments } \\
\text { - Foreign governments } \\
\text { - Consumer groups } \\
\text { - Unions }\end{array}$ \\
\hline Influencers & $\begin{array}{l}\text { - Government } \\
\text { - SEC } \\
\text { - Outside directors }\end{array}$ & - EPA/OSHA & $\begin{array}{l}\text { - Nader's Raiders } \\
\text { - Government } \\
\text { - Trade associations }\end{array}$ \\
\hline
\end{tabular}

Anexo D - Modelo Ibase de Balanço Social para empresas em geral 
Receita líquida (RL)

Resultado operacional (RO)

Folha de pagamento bruta (FPB)

\section{Indicadores sociais internos}

Alimentação

Encargos sociais compulsórios

Previdência privada

Saúde

Segurança e sa úde no trabalho

Educação

Cultura

Capacitação e desenvolvimento profissional

Creches ou auxilio-creche

Participação nos lucros ou resultados

Outros

Total - Indicadores sociais internos

3. Indicadores sociais externos

Educação

Cultura

Saúde e saneamento

Esporte

Combate à fome e segurança alimentar

Outros

Total das contribuições para a sociedade

Tributos (excluídos encargos sociais)

Total - Indicadores sociais externos

\section{Indicadores ambientais}

Investimentos relacionados com a produção/operação da empresa Investimentos em programas e/ou projetos externos

Total dos investimentos em meio ambiente

Quanto ao estabelecimento de metas anuais para minimizar

resíduos, o consumo em geral na produção/operação e aumentar a eficácia na utilização de recursos naturais, a empresa:

\section{Indicadores do corpo funcional}

$\mathrm{N}^{\circ}$ de empregados(as) ao final do período

$\mathrm{N}^{\circ}$ de admissões durante o período

$\mathrm{N}^{\circ}$ de empregados(as) terceirizados(as)

$\mathrm{N}^{\circ}$ de estagiários(as)

$\mathrm{N}^{\circ}$ de empregados(as) acima de 45 anos

$\mathrm{N}^{\circ}$ de mulheres que trabalham na empresa

$\%$ de cargos de chefia ocupados por mulheres

$\mathrm{N}^{\circ}$ de negros(as) que trabalham na empresa

$\%$ de cargos de chefia ocupados por negros(as)

$\mathrm{N}^{\circ}$ de pessoas com deficiência ou necessidades especiais

\section{Informações relevantes quanto ao}

\section{exercício da cidadania empresarial}

2008

Relação entre a maior e a menor remuneração na empresa

Número total de acidentes de trabalho

Os projetos sociais e ambientais desenvolvidos pela empresa foram definidos por:

Os padrões de segurança e salubridade no ambiente

de trabalho foram definidos por:

Quanto à liberdade sindical, ao direito de negociação coletiva

e à representação interna dos(as) trabalhadores(as), a empresa:

A previdência privada contempla:

\section{A participação nos lucros ou resultados contempla:}

Na seleção dos fornecedores, os mesmos padrões éticos e de responsabilidade social e ambiental adotados pela empresa:

Quanto à participação de empregados(as) em programas de

trabalho voluntário, a empresa:

Número total de reclamações e críticas de consumidores(as):

\% de reclamações e críticas solucionadas:

Valor adicionado total a distribuir (em mil R\$):

Distribuição do Valor Adicionado (DVA): \begin{tabular}{|l|l|l}
\hline Valor (mil R\$) $\%$ Sobre FPB $\quad \%$ Sobre RL \\
\hline
\end{tabular}

\begin{tabular}{lll} 
Valor (mil R\$) $\%$ Sobre FPB $\quad \%$ Sobre RL \\
\hline
\end{tabular}

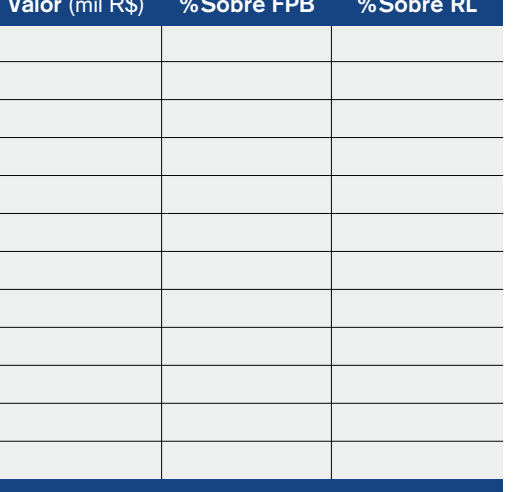

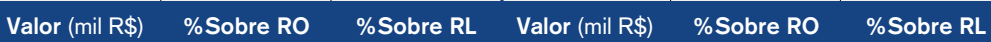

( ) não possui metas ( ) cumpre de 51 a $75 \%$ ( ) cumpre de 0 a $50 \%$ ( ) cumpre de 76 a $100 \%$

( ) não possui metas ( ) cumpre de 51 a $75 \%$

( ) cumpre de 0 a $50 \%$ ( ) cumpre de 76 a $100 \%$

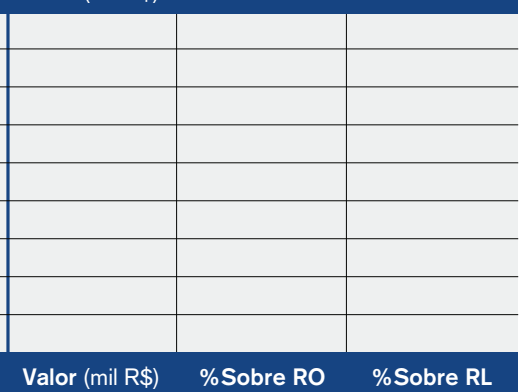

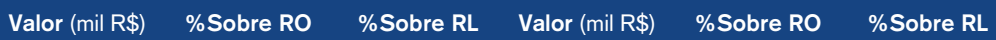

( )

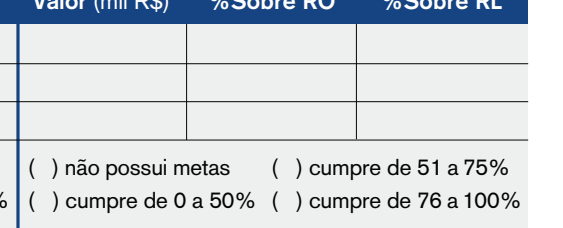

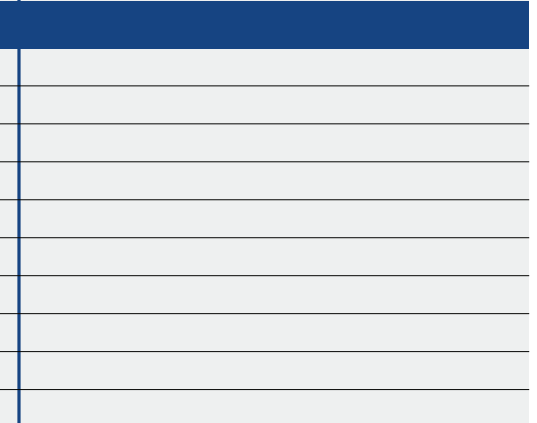

2008

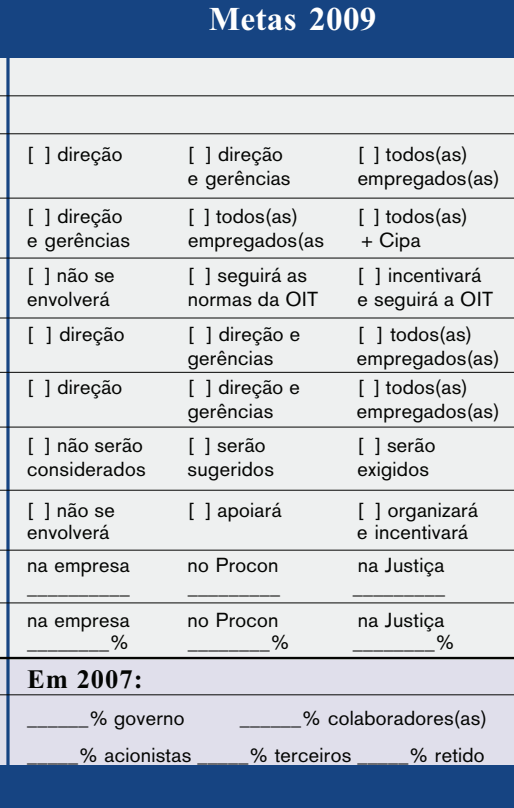

\section{Outras informações}

\begin{tabular}{|c|c|c|}
\hline [ ] direção & $\begin{array}{l}\text { [ ] direção } \\
\text { e gerências }\end{array}$ & $\begin{array}{l}\text { [ ] todos(as) } \\
\text { empregados(as) }\end{array}$ \\
\hline $\begin{array}{l}\text { [ ] direção } \\
\text { e gerências }\end{array}$ & $\begin{array}{l}\text { [ ] todos(as) } \\
\text { empregados(as }\end{array}$ & $\begin{array}{l}\text { [ ] todos(as) } \\
+ \text { Cipa }\end{array}$ \\
\hline $\begin{array}{l}\text { [ ] não se } \\
\text { envolve }\end{array}$ & $\begin{array}{l}\text { [ ] segue as } \\
\text { normas da OIT }\end{array}$ & $\begin{array}{l}\text { [ ] incentiva e } \\
\text { segue a OIT }\end{array}$ \\
\hline [ ] direção & $\begin{array}{l}\text { [ ] direção e } \\
\text { gerências }\end{array}$ & $\begin{array}{l}\text { [ ] todos(as) } \\
\text { empregados(as) }\end{array}$ \\
\hline [ ] direção & $\begin{array}{l}\text { [ ] direção e } \\
\text { gerências }\end{array}$ & $\begin{array}{l}\text { [ ] todos(as) } \\
\text { empregados(as) }\end{array}$ \\
\hline $\begin{array}{l}\text { [ ] não são } \\
\text { considerados }\end{array}$ & $\begin{array}{l}\text { [ ] são } \\
\text { sugeridos }\end{array}$ & [ ] são exigidos \\
\hline $\begin{array}{l}\text { [ ] não se } \\
\text { envolve }\end{array}$ & [ ] apóia & $\begin{array}{l}\text { [ ] organiza } \\
\text { e incentiva }\end{array}$ \\
\hline na empresa & no Procon & na Justiça \\
\hline $\begin{array}{r}\text { na empresa } \\
\%\end{array}$ & $\begin{array}{r}\text { no Procon } \\
\%\end{array}$ & $\begin{array}{r}\text { na Justiça } \\
\%\end{array}$ \\
\hline \multicolumn{3}{|l|}{ Em 2008: } \\
\hline \multirow{2}{*}{$\begin{array}{r}\% \text { governo } \\
\% \text { acionistas }\end{array}$} & \multicolumn{2}{|c|}{$\%$ colaboradores(as) } \\
\hline & \multicolumn{2}{|c|}{$\%$ terceiros } \\
\hline
\end{tabular}




\section{Instruç̄ões para o preenchimento}

$\begin{array}{ll}\text { Realização } & \begin{array}{l}\text { Este Balanço Social (BS) deve apresentar os projetos e as ações sociais } \\ \text { e ambientais efetivamente realizados pela empresa }\end{array} \\ \begin{array}{l}\text { Sugestão: este BS deve ser o resultado de amplo processo participativo } \\ \text { que envolva a comunidade interna e externa }\end{array}\end{array}$

Publicação

Este BS deve ser apresentado como complemento em outros tipos de demonstrações financeiras e socioambientais; publicado isoladamente em jornais e revistas; amplamente divulgado entre funcionários(as), clientes, fornecedores e a sociedade. Pode ser acompanhado de outros itens e de informações qualitativas (textos e fotos) que a empresa julgue necessários

Selo "Balanço Social Ibase/Betinho"

A empresa que realizar e publicar o seu balanço social, utilizando este modelo mínimo sugerido pelo Ibase, pode receber o direito de utilizar o Selo Balanço Social Ibase/Betinho nos seus documentos, relatórios, papelaria, produtos, embalagens, site etc. Mais informações e normas: www.balancosocial.org.br

RESTRIÇÕES: o Selo Balanço Social Ibase/Betinho NÃO será fornecido às empresas de cigarro, armas de fogo/munições e bebidas alcoólicas.

O Ibase não concede, suspende e/ou retira o Selo Balanço Social Ibase/Betinho conforme critérios estabelecidos no site www.balancosocial.org.br

Base de cálculo

Receita líquida

\section{Itens incluídos}

Receita bruta excluída dos impostos, contribuições, devoluções, abatimentos e descontos comerciais

Resultado operacional

Este se encontra entre o Lucro Bruto e o LAIR (Lucro Antes do Imposto de Renda), ou seja, antes das receitas e despesas não operacionais

Folha de pagamento bruta

Somatório de remuneração (salários, gratificações, comissões e abonos), $13^{\circ}$ salário, férias e encargos sociais compulsórios (INSS, FGTS e contribuição social).

\section{Indicadores sociais internos}

Alimentação

Gastos com restaurante, vale-refeição, lanches, cestas básicas e outros relacionados à alimentação de empregados(as)

Previdência privada

Planos especiais de aposentadoria, fundações previdenciárias, complementações de benefícios a aposentados(as) e seus dependentes

Saúde

Plano de saúde, assistência médica, programas de medicina preventiva, programas de qualidade de vida e outros gastos com saúde, inclusive de aposentados(as)

Educação

Gastos com ensino regular em todos os níveis, reembolso de educação, bolsas, assinaturas de revistas, gastos com biblioteca (excluído pessoal) e outros gastos com educação

Cultura

Gastos com eventos e manifestações artísticas e culturais (música, teatro, cinema, literatura e outras artes)

Capacitação e desenvolvimento profissional

Recursos investidos em treinamentos, cursos, estágios (excluído os salários) e gastos voltados especificamente para capacitação relacionada com a atividade desenvolvida por empregados(as)

Creches ou auxílio-creche

Creche no local ou auxílio-creche a empregados(as)

Participação nos lucros ou resultados

Participações que não caracterizem complemento de salários

Outros benefícios

Seguros (parcela paga pela empresa), empréstimos (só o custo), gastos com atividades recreativas, transportes, moradia e outros benefícios oferecidos a empregados(as) podem ser aqui enumerados

\section{Indicadores sociais externos}

Total das contribuições para a sociedade

Somatório dos investimentos na comunidade que aparecem discriminados

Os itens na tabela aparecem como indicação de setores importantes onde a empresa deve investir (como habitação, creche, lazer e diversão, por exemplo). Porém podem aparecer aqui somente os investimentos focais que a empresa realiza regularmente

Tributos (excluídos encargos sociais) Impostos, contribuições e taxas federais, estaduais e municipais

\section{Indicadores ambientais}

Investimentos relacionados com a

produção/operação da empresa Investimentos, monitoramento da qualidade dos resíduos/efluentes, despoluição, gastos com
a introdução de métodos não-poluentes, auditorias ambientais, programas de educação ambiental para os(as) funcionários(as) e outros gastos com o objetivo de incrementar e buscar o melhoramento contínuo da qualidade ambiental na produção/operação da empresa

Investimentos em programas/projetos externos

Despoluição, conservação de recursos ambientais, campanhas ecológicas e educação socioambiental para a comunidade externa e para a sociedade em geral

Metas anuais

Resultado médio percentual alcançado pela empresa no cumprimento de metas ambientais estabelecidas pela própria corporação, por organizações da sociedade civil e/ou por parâmetros internacionais como o Global Reporting Initiative (GRI)

\section{Indicadores do corpo funciona}

$N^{\circ}$ de negros(as) que trabalham na empresa

Considerar como trabalhadores(as) negros(as) o somatório de indivíduos classificados/autodeclarados como de pele preta e parda (conforme a RAIS)

6. Informações relevantes

Relação entre a maior e a menor remuneração

Resultado absoluto da divisão da maior remuneração pela meno

Número total de acidentes de trabalho

Normas

Todos os acidentes de trabalho registrados durante o ano

Conforme as Convenções 87, 98, 135 e 154 da Organização Internacional do Trabalho (OIT) e os itens da norma Social Accountability 8000 (SA 8000)

Mais informações: www.balancosocial.org.br

Outras informações importantes quanto ao exercício da responsabilidade social, ética e transparência.

Declarações para as empresas que solicitaram o Selo Balanço Social Ibase/Betinho. 
Anexo E - Modelo de DVA para empresas em geral - CPC n. ${ }^{0}$ 09/2008

\begin{tabular}{|c|c|c|}
\hline DESCRIÇÃO & $\begin{array}{c}\text { Em } \\
\text { milhares } \\
\text { de reais } \\
20 X 1 \\
\end{array}$ & $\begin{array}{c}\text { Em } \\
\text { milhares } \\
\text { de reais } \\
\text { 20X0 }\end{array}$ \\
\hline \multicolumn{3}{|l|}{1 - RECEITAS } \\
\hline \multicolumn{3}{|l|}{ 1.1) Vendas de mercadorias, produtos e serviços } \\
\hline \multicolumn{3}{|l|}{ 1.2) Outras receitas } \\
\hline \multicolumn{3}{|l|}{ 1.3) Receitas relativas à construção de ativos próprios } \\
\hline \multicolumn{3}{|l|}{ 1.4) Provisão para créditos de liquidação duvidosa - Reversão / (Constituição) } \\
\hline \multicolumn{3}{|l|}{2 - INSUMOS ADQUIRIDOS DE TERCEIROS } \\
\hline \multicolumn{3}{|l|}{ (inclui os valores dos impostos - ICMS, IPI, PIS e COFINS) } \\
\hline \multicolumn{3}{|l|}{ 2.1) Custos dos produtos, das mercadorias e dos serviços vendidos } \\
\hline \multicolumn{3}{|l|}{ 2.2) Materiais, energia, serviços de terceiros e outros } \\
\hline \multicolumn{3}{|l|}{ 2.3) Perda / Recuperação de valores ativos } \\
\hline \multicolumn{3}{|l|}{ 2.4) Outras (especificar) } \\
\hline \multicolumn{3}{|l|}{3 - VALOR ADICIONADO BRUTO (1-2) } \\
\hline \multicolumn{3}{|l|}{4 - DEPRECIAÇÃO, AMORTIZAÇÃO E EXAUSTÃO } \\
\hline \multicolumn{3}{|l|}{5 - VALOR ADICIONADO LÍQUIDO PRODUZIDO PELA ENTIDADE (3-4) } \\
\hline \multicolumn{3}{|l|}{6 - VALOR ADICIONADO RECEBIDO EM TRANSFERENCIA } \\
\hline \multicolumn{3}{|l|}{ 6.1) Resultado de equivalência patrimonial } \\
\hline \multicolumn{3}{|l|}{ 6.2) Receitas financeiras } \\
\hline \multicolumn{3}{|l|}{ 6.3) Outras } \\
\hline \multicolumn{3}{|l|}{7 - VALOR ADICIONADO TOTAL A DISTRIBUIR (5+6) } \\
\hline \multicolumn{3}{|l|}{8 - DISTRIBUIÇÃO DO VALOR ADICIONADO (*) } \\
\hline \multicolumn{3}{|l|}{ 8.1) Pessoal } \\
\hline \multicolumn{3}{|l|}{ 8.1.1 - Remuneração direta } \\
\hline \multicolumn{3}{|l|}{$8.1 .2-$ Benefícios } \\
\hline \multicolumn{3}{|l|}{$8.1 .3-$ F.G.T.S } \\
\hline \multicolumn{3}{|l|}{ 8.2) Impostos, taxas e contribuições } \\
\hline \multicolumn{3}{|l|}{$8.2 .1-$ Federais } \\
\hline \multicolumn{3}{|l|}{8.2 .2 - Estaduais } \\
\hline \multicolumn{3}{|l|}{8.2 .3 - Municipais } \\
\hline \multicolumn{3}{|l|}{ 8.3) Remuneração de capitais de terceiros } \\
\hline $8.3 .1-$ Juros & & \\
\hline $8.3 .2-$ Aluguéis & & \\
\hline 8.3 .3 - Outras & & \\
\hline 8.4) Remuneração de Capitais Próprios & & \\
\hline 8.4.1 - Juros sobre o Capital Próprio & & \\
\hline 8.4 .2 - Dividendos & & \\
\hline 8.4.3 - Lucros retidos / Prejuízo do exercício & & \\
\hline 8.4.4 - Participação dos não-controladores nos lucros retidos (só p/ consolidação) & & \\
\hline
\end{tabular}

(*) O total do item 8 deve ser exatamente igual ao item 7. 
Anexo F - Contas Econômicas Integradas 2006 (IBGE, 2008b) 


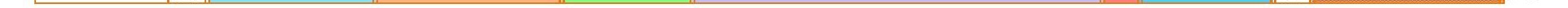




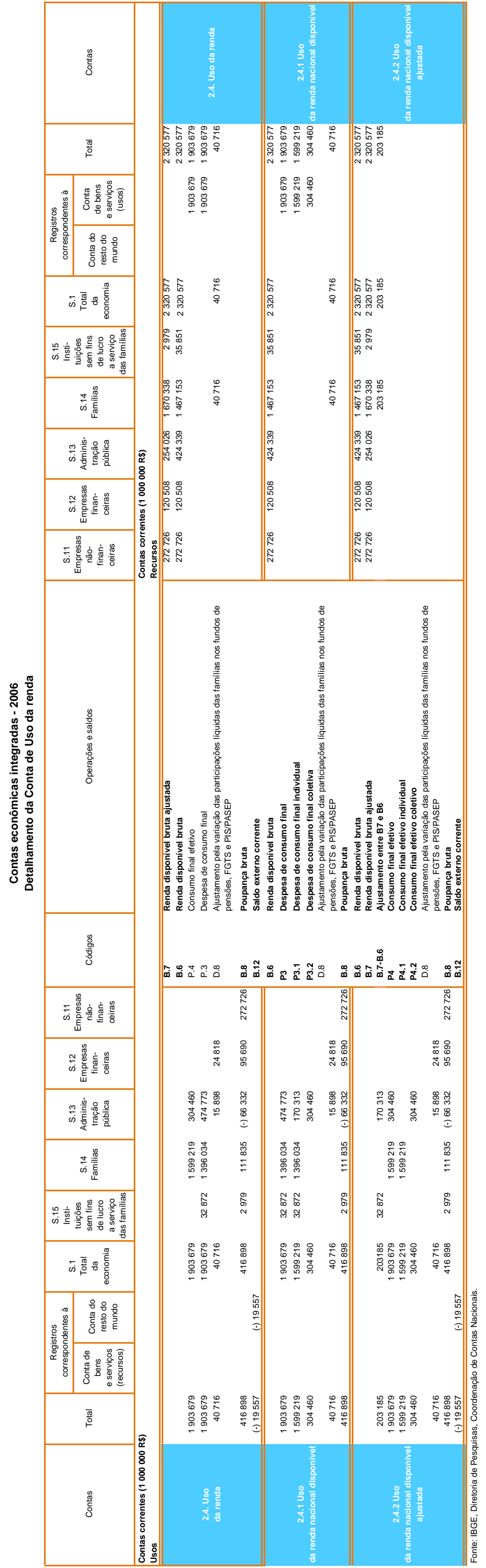


Anexo G - Tabela de Recursos e Usos 2006 (IBGE, 2008b) 


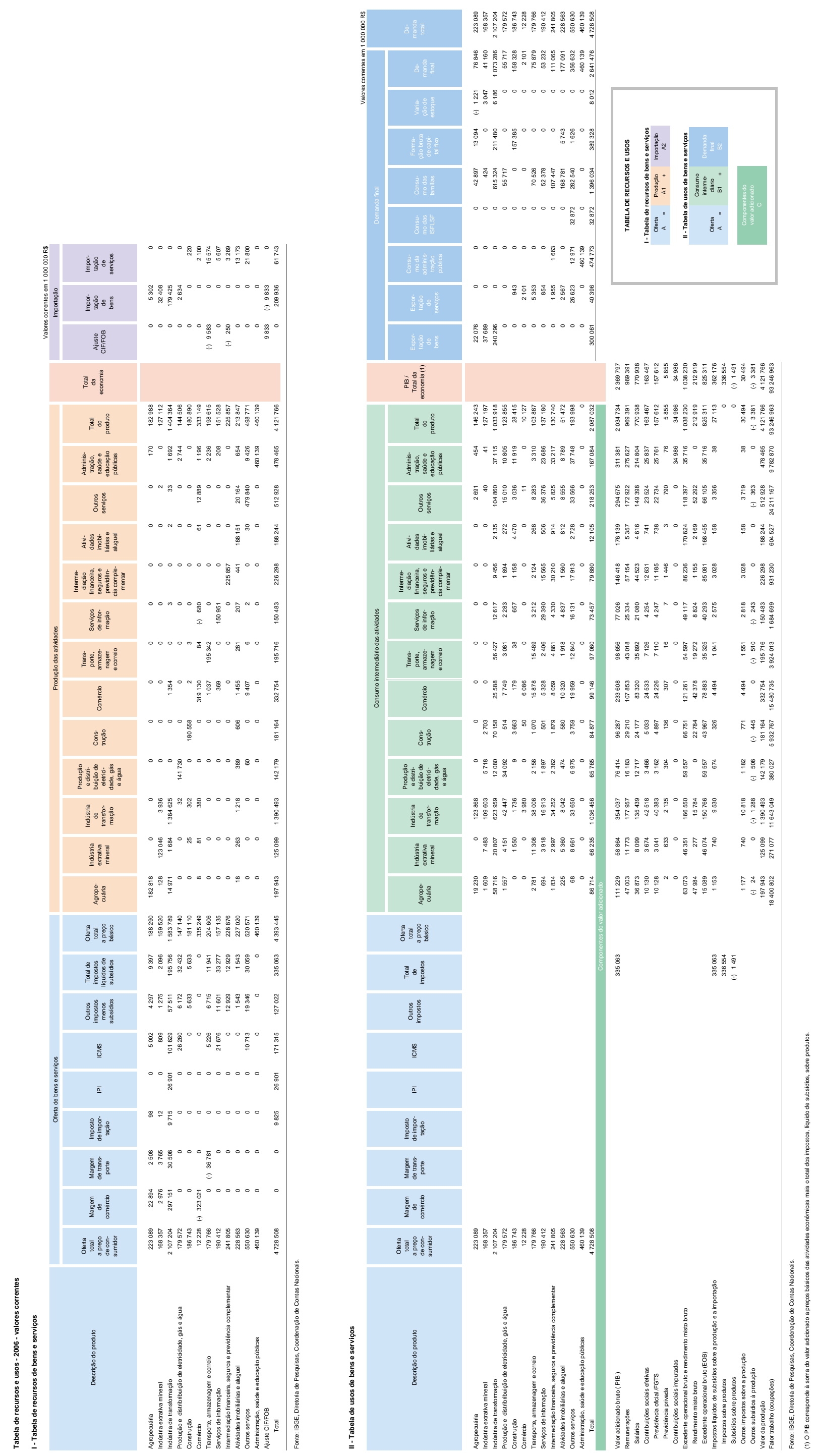
Anexo H - DVA da empresa Votorantim Celulose e Papel S.A.

00043-4

VOTORANTIM CELULOSE E PAPEL S.A.

DFP 31/12/2008 LS

\begin{tabular}{|c|c|c|c|c|}
\hline \multicolumn{5}{|c|}{ Demonstração do Valor Adicionado Consolidado - Método Indireto } \\
\hline \multicolumn{5}{|l|}{ (Reais Mil) } \\
\hline Código da Conta & Descrição da Conta & $\begin{array}{c}01 / 01 / 2008 \text { a } \\
31 / 12 / 2008\end{array}$ & $\begin{array}{c}01 / 01 / 2007 \text { a } \\
31 / 12 / 2007\end{array}$ & $\begin{array}{c}01 / 01 / 2006 \text { a } \\
31 / 12 / 2006\end{array}$ \\
\hline 6.01 & Receitas & 6.357 .074 & 3.753 .212 & 4.358 .093 \\
\hline 6.01 .01 & Vendas Mercadorias, Produtos e Serviços & 3.404 .546 & 3.620 .104 & 4.362 .726 \\
\hline 6.01 .02 & Outras Receitas & 0 & 0 & 0 \\
\hline 6.01 .03 & Receitas refs. à Constr. Ativos Próprios & 2.953 .630 & 133.880 & 0 \\
\hline 6.01 .04 & Provisão/Rev. Créds. Liquidação Duvidosa & -1.102 & -772 & -4.633 \\
\hline 6.02 & Insumos Adquiridos de Terceiros & -4.679 .964 & -1.278 .779 & -1.917 .994 \\
\hline 6.02 .01 & Custos Prods., Mercs. e Servs. Vendidos & -934.310 & -885.430 & -987.012 \\
\hline 6.02 .02 & Materiais-Energia-Servs Terceiros-Outros & -3.745 .654 & -393.349 & -930.982 \\
\hline 6.02 .03 & Perda/Recuperação de Valores Ativos & 0 & 0 & 0 \\
\hline 6.02 .04 & Outros & 0 & 0 & 0 \\
\hline 6.03 & Valor Adicionado Bruto & 1.677 .110 & 2.474 .433 & 2.440 .099 \\
\hline 6.04 & Retenções & -501.778 & -739.936 & -727.550 \\
\hline 6.04 .01 & Depreciação, Amortização e Exaustão & -324.865 & -449.826 & -550.337 \\
\hline 6.04 .02 & Outras & -176.913 & -290.110 & -177.213 \\
\hline 6.05 & Valor Adicionado Líquido Produzido & 1.175 .332 & 1.734 .497 & 1.712 .549 \\
\hline 6.06 & Vlr Adicionado Recebido em Transferência & 1.023 .064 & 1.615 .598 & 500.065 \\
\hline 6.06 .01 & Resultado de Equivalência Patrimonial & 664 & 997 & -49.722 \\
\hline 6.06 .02 & Receitas Financeiras & 1.022 .400 & 1.614 .601 & 549.787 \\
\hline 6.06 .03 & Outros & 0 & 0 & 0 \\
\hline 6.07 & Valor Adicionado Total a Distribuir & 2.198 .396 & 3.350 .095 & 2.212 .614 \\
\hline 6.08 & Distribuição do Valor Adicionado & 2.198 .396 & 3.350 .095 & 2.212 .614 \\
\hline 6.08 .01 & Pessoal & 332.433 & 363.533 & 359.303 \\
\hline 6.08 .01 .01 & Remuneração Direta & 233.577 & 249.969 & 225.283 \\
\hline 6.08 .01 .02 & Benefícios & 83.704 & 96.430 & 60.004 \\
\hline 6.08 .01 .03 & F.G.T.S. & 15.152 & 17.134 & 21.199 \\
\hline 6.08 .01 .04 & Outros & 0 & 0 & 52.817 \\
\hline 6.08 .02 & Impostos, Taxas e Contribuições & -94.353 & 479.264 & 658.458 \\
\hline 6.08 .02 .01 & Federais & -339.212 & 235.890 & 386.515 \\
\hline 6.08 .02 .02 & Estaduais & 237.610 & 240.840 & 265.359 \\
\hline 6.08 .02 .03 & Municipais & 7.249 & 2.534 & 6.584 \\
\hline 6.08 .03 & Remuneração de Capitais de Terceiros & 3.270 .663 & 1.669 .700 & 216.979 \\
\hline 6.08 .03 .01 & Juros & 3.270 .663 & 1.669 .700 & 138.650 \\
\hline 6.08 .03 .02 & Aluguéis & 0 & 0 & 6.509 \\
\hline 6.08 .03 .03 & Outras & 0 & 0 & 71.820 \\
\hline 6.08 .04 & Remuneração de Capitais Próprios & -1.310 .347 & 837.598 & 977.874 \\
\hline 6.08 .04 .01 & Juros sobre o Capital Próprio & 0 & 318.000 & 320.158 \\
\hline 6.08 .04 .02 & Dividendos & 0 & 0 & 0 \\
\hline 6.08 .04 .03 & Lucros Retidos / Prejuízo do Exercício & -1.310 .347 & 519.598 & 657.716 \\
\hline 6.08 .04 .04 & Part. Não Controladores Lucros Retidos & 0 & 0 & 0 \\
\hline 6.08 .05 & Outros & 0 & 0 & 0 \\
\hline
\end{tabular}

FONTE: Sistema de Divulgação de Informações sobre as empresas listadas - BOVESPA - acesso em 25/07/2009 


\section{Anexo I - DVA da empresa Aracruz Celulose S.A.}

00043-4

ARACRUZ CELULOSE S.A.

DFP 31/12/2008 LS

\begin{tabular}{|c|c|c|c|c|}
\hline \multicolumn{5}{|c|}{ Demonstração do Valor Adicionado Consolidado - Método Indireto } \\
\hline Código da Conta & Descrição da Conta & $\begin{array}{c}01 / 01 / 2008 \text { a } \\
31 / 12 / 2008\end{array}$ & $\begin{array}{c}01 / 01 / 2007 \text { a } \\
31 / 12 / 2007\end{array}$ & $\begin{array}{c}01 / 01 / 2006 \text { a } \\
31 / 12 / 2006\end{array}$ \\
\hline 6.01 & Receitas & 3.816 .990 & 3.966 .138 & 3.943 .693 \\
\hline 6.01 .01 & Vendas Mercadorias, Produtos e Serviços & 3.743 .853 & 3.895 .731 & 3.893 .636 \\
\hline 6.01 .02 & Outras Receitas & 73.137 & 70.407 & 50.057 \\
\hline 6.01 .03 & Receitas refs. à Constr. Ativos Próprios & 0 & 0 & 0 \\
\hline 6.01 .04 & Provisão/Rev. Créds. Liquidação Duvidosa & 0 & 0 & 0 \\
\hline 6.02 & Insumos Adquiridos de Terceiros & -2.210 .384 & -2.082 .741 & -1.880 .008 \\
\hline 6.02 .01 & Custos Prods., Mercs. e Servs. Vendidos & -1.597 .106 & -1.588 .441 & -1.428 .846 \\
\hline 6.02 .02 & Materiais-Energia-Servs Terceiros-Outros & -613.278 & -494.300 & -451.162 \\
\hline 6.02 .03 & Perda/Recuperação de Valores Ativos & 0 & 0 & 0 \\
\hline 6.02 .04 & Outros & 0 & 0 & 0 \\
\hline 6.03 & Valor Adicionado Bruto & 1.606 .606 & 1.883 .397 & 2.063 .685 \\
\hline 6.04 & Retenções & -696.569 & -661.758 & -646.869 \\
\hline 6.04 .01 & Depreciação, Amortização e Exaustão & -696.569 & -661.758 & -646.869 \\
\hline 6.04 .02 & Outras & 0 & 0 & 0 \\
\hline 6.05 & Valor Adicionado Líquido Produzido & 910.037 & 1.221 .639 & 1.416 .816 \\
\hline 6.06 & Vlr Adicionado Recebido em Transferência & -4.284 .845 & 214.149 & 349.218 \\
\hline 6.06 .01 & Resultado de Equivalência Patrimonial & -1.958 & -1.322 & -607 \\
\hline 6.06 .02 & Receitas Financeiras & -4.282 .887 & 215.471 & 349.825 \\
\hline 6.06 .03 & Outros & 0 & 0 & 0 \\
\hline 6.07 & Valor Adicionado Total a Distribuir & -3.374 .808 & 1.435 .788 & 1.766 .034 \\
\hline 6.08 & Distribuição do Valor Adicionado & -3.374 .808 & 1.435 .788 & 1.766 .034 \\
\hline 6.08 .01 & Pessoal & 305.935 & 300.840 & 278.545 \\
\hline 6.08 .01 .01 & Remuneração Direta & 202.091 & 190.428 & 173.015 \\
\hline 6.08.01.02 & Benefícios & 89.952 & 98.048 & 93.420 \\
\hline 6.08 .01 .03 & F.G.T.S. & 13.892 & 12.364 & 12.110 \\
\hline 6.08.01.04 & Outros & 0 & 0 & \\
\hline 6.08 .02 & Impostos, Taxas e Contribuições & -973.325 & 208.288 & 168.572 \\
\hline 6.08.02.01 & Federais & -1.035 .529 & 374.434 & 179.937 \\
\hline 6.08.02.02 & Estaduais & 52.934 & -172.991 & -13.026 \\
\hline 6.08.02.03 & Municipais & 9.270 & 6.845 & 1.661 \\
\hline 6.08 .03 & Remuneração de Capitais de Terceiros & 1.485 .024 & -129.394 & 151.267 \\
\hline 6.08 .03 .01 & Juros & 262.975 & 226.158 & 327.749 \\
\hline 6.08.03.02 & Aluguéis & 0 & 0 & 0 \\
\hline 6.08.03.03 & Outras & 1.222 .049 & -355.552 & -176.482 \\
\hline 6.08 .04 & Remuneração de Capitais Próprios & -4.213 .455 & 1.042 .204 & 1.150 .131 \\
\hline 6.08.04.01 & Juros sobre o Capital Próprio & 155.000 & 498.900 & 485.000 \\
\hline 6.08.04.02 & Dividendos & 0 & 0 & 0 \\
\hline 6.08 .04 .03 & Lucros Retidos / Prejuízo do Exercício & -4.368 .455 & 543.304 & 665.131 \\
\hline 6.08.04.04 & Part. Não Controladores Lucros Retidos & 0 & 0 & \\
\hline 6.08 .05 & Outros & 21.013 & 13.850 & 17.519 \\
\hline 6.08.05.01 & Apoio, Patrocínio e Doações & 21.013 & 13.850 & 17.519 \\
\hline
\end{tabular}

FONTE: Sistema de Divulgação de Informações sobre as empresas listadas - BOVESPA - acesso em 31/05/2009 